FACULDADE DE FILOSOFIA, LETRAS E CIÊNCIAS HUMANAS

DEPARTAMENTO DE GEOGRAFIA

PROGRAMA DE GEOGRAFIA HUMANA

\title{
A Contenção da Política: Usos de videomonitoramento para controle social nos espaços públicos de São Paulo
}

Letícia Maria Vieira

Dissertação apresentada ao Programa de Pós-Graduação em Geografia Humana do Departamento de Gegrafia da Faculdade de Filosofia, Letras e Ciências Humanas da Universidade de São Paulo para obtenção do título de mestre.

Orientador: Rodrigo Valverde

São Paulo 
Autorizo a reprodução e divulgação total ou parcial deste trabalho, por qualquer meio convencional ou eletrônico, para fins de estudo e pesquisa, desde que citada a fonte.

Catalogação na Publicação

Serviço de Biblioteca e Documentação

Faculdade de Filosofia, Letras e Ciências Humanas da Universidade de São Paulo

V657C

Vieira, Letícia Maria

A contenção da política: usos de videomonitoramento para controle social nos espaços públicos de São

Paulo / Letícia Maria Vieira ; orientador Rodrigo Valverde. - São Paulo, 2018.

$170 \mathrm{f}$.

Dissertação (Mestrado) - Faculdade de Filosofia, Letras e Ciências Humanas da Universidade de São Paulo. Departamento de Geografia. Área de concentração: Geografia Humana.

1. Espaço público. 2. Violência. 3. Guerra psicológica. I. Valverde, Rodrigo, orient. II. Título. 


\section{Resumo}

Essa dissertação é um estudo sobre o sistema Detecta, inicialmente apresentado pela Secretaria de Segurança Pública de São Paulo, em 2014. Ele seria um programa de videomonitoramento inteligente, instalado pela Microsoft, em uma parceria público-privada com o estado. Sua base era o programa de monitoramento da cidade de Nova lorque, nos Estados Unidos. No entanto, até 2018, embora o sistema continuasse ativo, a função de videomonitoramento inteligente não havia sido instalada. Ela foi substituída pelo programa de monitoramento de rodovias do antigo projeto Radar. Nessa dissertação trabalhamos com a questão central: o projeto Detecta foi um instrumento de controle que impactou na apropriação do espaço público da cidade de São paulo?. A hipótese que chegamos foi que o Detecta funcionou como uma peça de propaganda de guerra psicológica, em favor da normatização do espaço público e sua transformação em território das forças de segurança. Essa hipótese se sustenta em um estudo sobre a repercussão do Detecta e do videomonitoramento em jornais e outras mídias brasileiras, segundo diferentes grupos sociais.

Palavras-chaves: Espaço Público; Videomonitoramento; Violência; Sociedade de Controle; Guerra Psicológica.

\section{Abstract}

This dissertation is a study on the Detecta system, initially presented by the Public Security Secretariat of São Paulo, in 2014. It would be an intelligent video-monitoring program installed by Microsoft in a public-private partnership with the state. It was based on the monitoring program of the city of New York in the United States. However, by 2018, although the system remained active, the intelligent videomonitoring function had not been installed. It was replaced by the road monitoring program of an olf project called Radar. In this dissertation we work with the central question: Was the project Detecta an instrument of control that impacted in the appropriation of the public space of the city of São Paulo in Brazil?. The hypothesis we arrived at was that Detecta functioned as a piece of psychological war propaganda, in favor of the normatization of public space and its transformation into a territory of São Paulo's security forces. This hypothesis is supported by a study about the repercussion of Detecta and videomonitoring in newspapers and other Brazilian media, according to different social groups.

Keywords: Public Space; Videomonitoring; Violence; Control Society; Psychological Warfare. 


\section{Sumário}

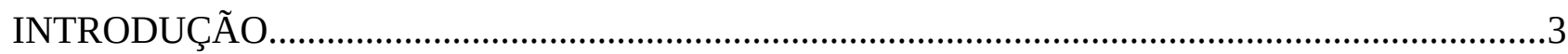

1.VIDEOMONITORAMENTO INTELIGENTE COMO UMA FERRAMENTA DE CONTROLE

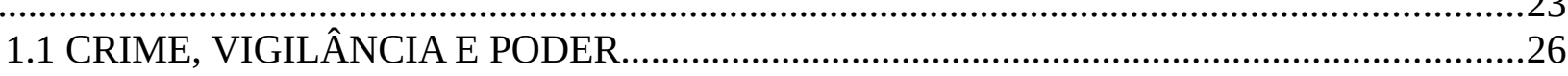

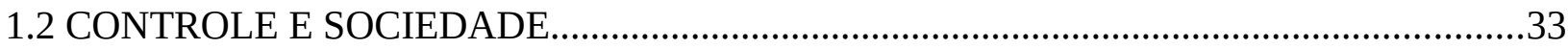

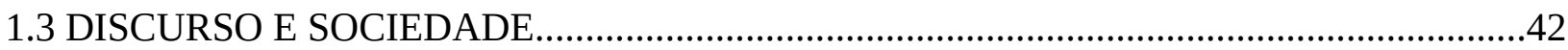

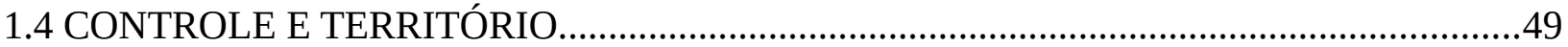

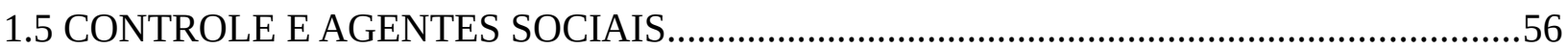

2. ASPECTOS DAS OPERAÇÕES PSICOLÓGICAS E GUERRA TOTAL NA DISPUTA PELO

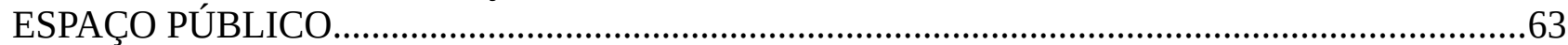

2.1 DEFINIÇÃO E OBJETIVO DA GUERRA PSICOLÓGICA.................................................66

2.2 FERRAMENTAS E ALVOS DA GUERRA PSICOLÓGICA......................................................72

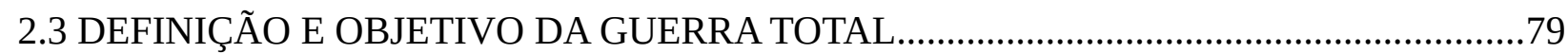

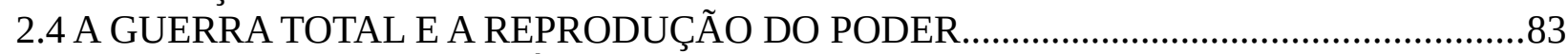

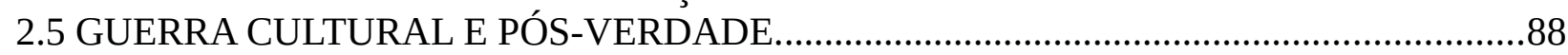

2.6 CONFLITO ENTRE AGENTES...................................................................................95

3. A UTOPIA DE UM O VIDEOMONITORAMENTO INTELIGENTE EM SÃO PAULO..........100

3.1 DETECTA: UM PROGRAMA PROMISSOR OU UM PROJETO NATIMORTO?..............101

3.2 O SISTEMA DETECTA COMO UM PROGRAMA DE INTELIGÊNCIA.............................107

3.3 UMA PROPAGANDA DE NARRATIVA INVEROSSÍMIL...............................................116

3.4 A PROPAGANDA CINZA CONTRA A APROPRIAÇÃO ESPONTÂNEA DO ESPAÇO.123

4. ASPECTOS DO IMPACTO DA GUERRA PSICOLÓGICA NA ATUAÇÃO ESPACIAL DO

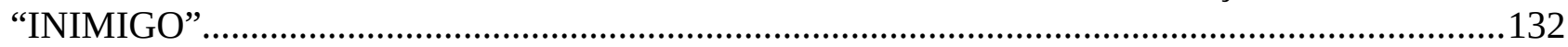

4.1 VIDEOMONITORAMENTO E O CONTROLE POLÍTICO..................................................133

4.2 SOCIEDADE DE CONTROLE E O MEDO DA DITADURA...........................................137

4.3 UMA CIÊNCIA DE CONTROLE DO PÚBLICO....................................................................141

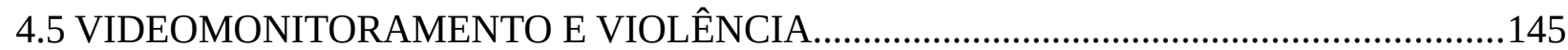

4.6 ASPECTOS DA SOCIEDADE DE CONTROLE NO BRASIL ………………………...........149

4.7 ASPECTOS DA RESISTÊNCIAS À SOCIEDADE DE CONTROLE...................................153

CONSIDERAÇÕES FINAIS..............................................................................................160

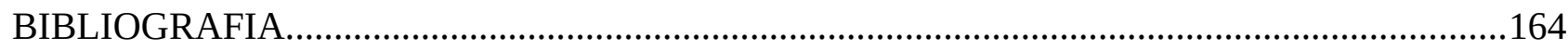




\section{INTRODUÇÃO}

O uso de videomonitoramento como ferramenta de controle sobre a população, sob o discurso do combate ao crime, é tema relevante na atualidade. A relação entre vigilância, liberdade, e controle, acrescida à reflexão sobre o impacto das novas tecnologias, leva a alguns pesquisadores a pensar que o capital oligopolista, aliado ao Estado, possui capacidades quase ilimitadas de controlar seus cidadãos. Talvez não à toa alguns dos governos que mais tem se fortalecido são justamente aqueles que praticam abertamente controle sobre a vida de sua população (China, Vietnã, etc.). No entanto, parte dessa nova capacidade de vigilância existe antes como discurso do que como realidade concreta, em especial quando se fala de videomonitoramento inteligente, capaz de identificar situações de risco e mesmo rosto de cidadãos específicos. $O$ fato de existir como discurso, no entanto, tem impacto real na organização da sociedade, e mesmo na apropriação do espaço público. Na verdade, possivelmente uma das principais formas de realização do controle social sobre o espaço seja justamente o que deriva do impacto do discurso sobre a legitimidade das formas de apropriação e a possível repressão às apropriações consideradas ilegítimas (e ilegais).

Na presente dissertação, buscamos entender qual foi o impacto do projeto Detecta, da Secretaria de Segurança Pública do Estado de São Paulo, que tinha como sua principal característica a instalação do videomonitoramento inteligente, na cidade de São Paulo. Para esse fim, buscamos responder a pergunta central: o projeto Detecta foi um instrumento de controle que impactou na apropriação do espaço público da cidade de São Paulo? A hipótese que formulamos, após a análise do que era o Detecta e de sua viabilidade, é que, do ponto de vista da disputa existente entre as formas de apropriação do espaço público, o Detecta funcionou como uma peça de propaganda da guerra psicológica em favor da normatização do espaço público. Tinha como um de seus alvos declarados a apropriação política do espaço público. Nesse sentido, como propaganda, visava criar o medo entre aqueles que se apropriassem do espaço público de forma espontânea, em especial para fins políticos, ao passo que se esforçava para promover o controle normativo do espaço público (ou seja: o fim da criminalidade e do "caos urbano"), em especial quando associado ao espaço urbano do centro expandido de São Paulo. Foi no centro da cidade de São Paulo que a polícia afirmou ter usado o Detecta, pela primeira 
vez, para auxiliar a repressão a movimentos sociais, em setembro de 2014.

O projeto Detecta ganhou destaque nos jornais de São Paulo a partir do dia 16 de abril de 2014, quando foi anunciada a parceria entre a Secretaria da Segurança Pública do Estado de São Paulo (SSP) e a empresa Microsoft para a adaptação do software Detecta. A definição da Microsoft e da SSP quanto ao que era o Detecta, no entanto, apresentava pequenas distinções. A Secretaria de Segurança afirmou que, naquela data, era dado início a uma "nova fase do Detecta", dando a entender que se tratava de um projeto já desenvolvido por ela. Já a Microsoft definia o Detecta como "sistema de monitoramento inteligente, adquirido pelo Governo do Estado e desenvolvido pela Microsoft com a prefeitura de Nova York".

Segundo a secretaria, o Detecta seria a combinação do videomonitoramento, do monitoramento inteligente (análise computacional de padrões de imagem) e do georreferenciamento. Isso permitiria a polícia ter acesso a um mapa de alertas de crimes, além de possibilitar a localização em tempo real de carros através da combinação de número parcial de placas e características dos carros. Conforme a SSP, "isso também pode ser feito para o caso de um procurado pela polícia" (SSP: "Mapa de Crimes", 17/04/2014). A Microsoft explicou, na época, que isso era possível pela combinação das tecnologias de Big Data e de Business Intelligence. Apesar do projeto ambicioso de ampliação da capacidade de monitoramento do aparato de segurança do Estado de São Paulo, em abril de 2017, a função de videomonitoramento inteligente, conforme o Tribunal de Contas do Estado de São Paulo, ainda não havia sido desenvolvida. Na verdade, havia sido até mesmo excluída do contrato entre a SSP e a Companhia de Processamento de Dados do Estado (Prodesp), que assumiu a responsabilidade de administração e adoção do sistema Detecta.

No caso do Brasil, um videomonitoramento capaz de identificar situações de risco e suspeitos sob vigilância serviria, também, para aumentar a capacidade de reprimir os movimentos populares que disputam o espaço urbano. Essa afirmação não se trata de mera hipótese, mas de intenção declarada, desde setembro de 2014, quando o Coronel Glauco Silva de Carvalho afirmou que, mesmo em fase de teste, o Detecta havia ajudado na operação de "reestabelecimento da ordem pública", na ocasião do enfrentamento entre sem tetos e a Polícia Militar, no dia 16 de setembro de 2014, pela ocasião de uma 
tentativa de reintegração de posse no centro da cidade de São Paulo. O uso político de videomonitoramento para identificação de lideranças de movimentos sociais é fato conhecido pela população brasileira. A própria polícia não esconde que vigia essas direções, como ficou claro na ocasião da detenção de Boulos, líder do MTST, no dia 17 de janeiro de 2017, quando foi afirmado pela polícia: "Temos horas de filmagens suas de outras manifestações e ocupações e sabemos que você é liderança, você está detido por desacato, obstrução da via, obstrução da justiça e incitação de violência", conforme relatado pelo coletivo Jornalistas Livres (Carta Maior: "Guilherme Boulos, do MTST, é preso pela PM em desocupação violenta na zona leste de SP”, 17/01/2017).

Essa breve trajetória descrita nos parágrafos acima ajuda a entender a abordagem aqui proposta acerca do Detecta. O fato de ser um projeto onde as partes envolvidas definem de forma diferente o seu conteúdo; onde se promete uma tecnologia que em momento algum foi instalada; e que tem um de seus usos declarados a repressão a movimentos políticos; em uma sociedade em que a polícia detém ilegalmente lideranças políticas utilizando como argumento a existência de imagens da referida liderança em outros atos, permite a leitura do Detecta não apenas como um programa de videomonitoramento. A propaganda realizada em cima do Detecta, em uma sociedade que coíbe manifestações através da intimidação de lideranças (o que pode ser definido como Terror de Estado), deve ser entendida também como uma forma de intimidação que visa reforçar o controle do aparato de segurança sobre o espaço, através da manipulação da percepção da realidade de parcela da população.

Para buscar entender como o Detecta operou como uma ferramenta de manipulação da percepção subjetiva da população, partimos de uma leitura com base em Deleuze. Entendemos que a atual fase de organização das sociedades pode ser definida como da sociedade de controle. De forma simplificada, pode se definir como um dos aspectos da sociedade de controle que, nela, os agrupamentos sociais (classes, setores, segmentos, e grupos sociais) são tratados de forma estatística, e o indivíduo é tratado como uma unidade de um corpo. No lugar de se disciplinar individualmente cada membro do corpo social, modela-se o grupo. Isso é feito através de incentivos positivos e negativos personalizados para os distintos grupos (e no limite, para cada unidade do grupo). Esse mecanismo afeta a própria organização do espaço, ao criar a percepção que dados espaços são preferencialmente ocupados por um nicho social. Esses 
agrupamentos sociais se identificam antes como grupos desterritorializados, mas o pertencimento a um ou outro grupo serve como um cartão de entrada para o trânsito em determinados espaços. Essa relação entre modulação dos grupos sociais e organização da sociedade é tema que já está presente em parte da bibliografia especializada (como nas obras de Ignacio Ramonet e nas de Antonio Negri).

O estudo dos mecanismos concretos pelo qual se exercita a modelação das relações sociais no espaço, em especial no espaço urbano, no entanto, são ainda incipientes no que toca o interesse da Geografia pelas novas tecnologias. Uma obra que apontou alguns dos caminhos possíveis para entender esses mecanismos é o livro "Cidades Sitiadas", de Stephen Graham. Nela, o autor destacou que há um processo de renovação do autoritarismo, que usa a burocracia do Estado para exercer o controle sobre o espaço, identificando populações de risco, realizando criminalizações em massa de conjuntos populacionais, tratados como inimigos internos da sociedade, por representarem o potencial de distúrbio da ordem desejada, ou por simplesmente não aceitarem se restringir ao lugar que lhes foi estabelecido pelo regime vigente. Para esse combate, Graham aponta que as forças policiais e militares do Estado se armam para combater um inimigo que não veste um uniforme específico, o que significa tratar o público urbano como inimigo potencial. Como o que se combate não é uma força inimiga, mas sim grupos sociais e comportamentos indesejados, a guerra urbana se dá através do estabelecimento de uma arquitetura de sitiamento, onde guaritas são combinadas com instrumentos de vigilância, incluindo controle biométrico, CCTVs, GPS, etc.). Graham, no entanto, apenas centrou sua análise no impacto direto dessa arquitetura, sem levar em conta a disputa subjetiva (direta e indireta) sobre os comportamentos sociais. Ou seja, não tratou da disputa de percepções sobre tal arquitetura, que é também objeto de política oficial do Estado. Os próprios aparatos militares e de segurança de distintos países reconhecem que, atualmente, a disputa pelo controle espacial é antes de tudo uma disputa pelos corações e mentes sobre aquele espaço. A força bélica tem como intuito, conforme parte dos estrategistas estadunidenses, intimidar e dissuadir. Mas o sucesso da intimidação depende também da propaganda que reforça o moral de seus apoiadores, e quebra a vontade de seus adversários. No mundo militar, a manipulação das percepções e vontades faz parte das Operações Psicológicas, o que envolve o uso da mídia, de demonstração intimidadora de força, demonstração de solidariedade com inocentes, etc. Embora normalmente seja destinada para maximização dos efeitos das forças armadas, 
dentro do contexto das chamadas guerras híbridas, guerras de quarta geração, e guerras totais, a guerra contemporânea se realiza através da disputa subjetiva que envolve não mais apenas Estados, mas também facções políticas e sociais.

Se a tese de Stephen Graham acerca da arquitetura de guerra está correta, devemos, portanto, entender as populações que vivem nessas cidades sitiadas como agrupamentos e facções hostis às forças que realizam o cerco. Isso significa dizer que as forças de segurança públicas e privadas tratam os agentes sociais que interagem com o espaço público como inimigos (ou aliados) em potencial. Portanto, podem ser alvo de operações psicológicas que visem a modulação dos comportamentos em favor de uma apropriação normativa do espaço. Disso resulta que a mídia local pode ser utilizada (ou disputada) para gerar apoio às forças de segurança, para difamar grupos sociais considerados potencialmente nocivos, etc. Ainda, um programa da Secretaria de Segurança Pública pode ter, também, como um de seus objetivos o de causar um efeito psicológico (subjetivo) na população, mesmo que tenha pouco efeito concreto. Dessa forma, as forças de segurança podem influenciar o espaço e atingir seus objetivos (que incluem a manutenção da ordem) sem precisar atuar contra alvos individualizados. Ao contrário, atuam dentro do modelo de políticas públicas no contexto da sociedade de controle: atuam sobre conjuntos amostrais, sem visar a universalização. Em vez de atuar contra o criminoso individualizado, contra a perturbação específica da ordem, atuam contra os grupos e situações de risco, realizando o que David Garland ressaltou ser a "criminologia da vida cotidiana". Conforme a leitura aqui proposta, e que será discutido ao longo dos capítulos dessa dissertação, a operação psicológica, no contexto da disputa pelo espaço público, visa criar a sensação que determinados comportamentos, e agrupamentos, considerados disruptores da ordem sempre serão punidas, em especial quando presentes nas localidades protegidas pelo cerco do videomonitoramento. Desse raciocínio aqui proposto é que deriva nossa hipótese já anunciada.

Para fins de análise, pode-se entender a disputa pelo espaço público urbano como uma guerra entre dois agrupamentos sociais distintos: de um lado, estão as forças políticas, os grupos sociais, e os aparatos do Estado, que têm como projeto para o espaço público a constituição de uma utopia da assepsia, onde todo uso do espaço deve ocorrer conforme a norma pré-determinada, e sem conflitos; do outro, estão os grupos sociais e movimentos políticos e culturais que buscam reapropriar e ressignificar o espaço 
público de orgânica, entendendo que o espaço público é o locus da disputa entre os diferentes (o locus da política).

Com o intuito de melhor apresentar os argumentos que nos levam a tomar como provável a hipótese de que o Detecta também funcionou como uma peça de propaganda da Secretaria de Segurança Público do Estado de São Paulo como parte da operação psicológica de disputa pelo espaço público, a presente dissertação foi dividida em quatro capítulos, além dessa introdução e das considerações finais. Na presente introdução, buscaremos apresentar alguns aspectos sobre o que aqui entendemos por espaço público: o lócus do conflito público entre projetos distintos de sociedade leva a entender que os grupos sociais disputam tanto fisicamente o espaço público como disputam a concepção sobre o mesmo. As medidas tomadas pelos grupos podem tanto levar à conquistas objetivas quanto à subjetivas sobre o espaço público.

No primeiro capítulo será apresentada parte da contribuição de estudos influenciados por Deleuze e Guatarri que permitem entender a disputa subjetiva sobre o espaço, além de entender o conceito de modelação da população. Visa-se com isso como o Detecta pode ser entendido como uma ferramenta de segurança influenciada pela criminalística da vida cotidiana, e, portanto, é uma ferramenta que visa influenciar e moldar as relações sociais no espaço público. Ainda pretende-se ressaltar que o Detecta não é uma ação isolada, mas faz parte de um contexto de multiplicação de ferramentas de controle. Ele também depende da multiplicação de agentes, uma vez que parte importante da política de segurança voltada à modelação de comportamento é (a) a criação de uma rede de vigilância e intervenção no espaço; e (b) que a política seja publicamente conhecida, e seus sucessos (reais ou não) sejam divulgados. Disso resulta que os parceiros privados e a mídia que divulgou o Detecta também impactam na disputa espacial objetivada pelas políticas de videomonitoramento.

No segundo, serão apresentados estudos realizados sobre os conceitos de guerra psicológica e guerra total (incluindo conceitos alternativos como guerra de doutrinas, guerra de quarta geração, etc.). Grande parte dos estudos apresentados são documentos oficiais ou debates promovidos por agências de segurança ou de inteligência de distintos países, em especial dos EUA. Os estudos versam sobre o uso da propaganda e a disputa de opinião como parte da luta pela consolidação do modo de vida ocidental. Pretende-se 
no capítulo apontar que, apesar da secretaria de segurança de São Paulo não declarar seu esforço de disputa pelos "corações e mentes", a doutrina moderna de guerra e de segurança inclui esse tipo de esforço. Ainda, será argumentado que, portanto, o esforço para atingir ganhos subjetivos (com ou sem lastro em vitórias objetivas) é consciente por parte da secretaria do Estado de São Paulo.

No terceiro capítulo, serão analisadas reportagens e notas oficiais acerca do detecta. Foram escolhidos materiais que versassem diretamente sobre o detecta ou sobre monitoramento policial durante o período de vigência do Detecta. A análise do material visa entender a mudança do significado do Detecta, de um software de monitoramento inteligente para um sistema integrado de videomonitoramento, assim como a percepção pública sobre o mesmo. Espera-se dessa forma colocar em evidência que o Detecta foi um programa de guerra total, que visava não apenas melhorar a capacidade de monitoramento da polícia, mas também angariar apoio e desestimular dissidentes. $O$ objetivo do Detecta era, conforme se percebe pela narrativa construída através dos meios de comunicação que o apoiava. Ainda, será demonstrado que o Detecta não conseguiu sequer convencer aliados importantes na guerra psíquica pelo controle do espaço público.

O quarto capítulo será dedicado a apontar que, apesar da dificuldade do Detecta de influenciar a opinião pública geral, parte da mídia brasileira participa da guerra psicológica contra a utopia do espaço público político (onde impere a apropriação espontânea do espaço). O videomonitoramento aparece nos jornais como uma ferramenta importante para identificar e punir eventuais perturbadores da ordem pública, inclusive manifestantes políticos radicais e pichadores. No capítulo, busca-se demonstrar como parte da população que acredita que o espaço público deve ser livre para expressão política encarou a atuação da secretaria de segurança pública, e como existe o medo do uso do videomonitoramento para identificação e punição de militantes.

Antes de iniciar a análise do papel do Detecta na disputa pelo espaço público do centro expandido da cidade de São Paulo, é necessário realizar alguns apontamentos acerca do debate sobre as definições para o conceito de espaço público. Trata-se de tema que é objeto de largo estudo na geografia, e faz-se necessário deixar claro qual definição aqui usamos. Para isso, é necessário fazer breve recapitulação acerca de algumas das principais definições sobre o que é o espaço público, e como ele se 
relaciona com os aparatos de segurança do Estado.

A teoria geral que balizou os debates sobre espaço público possui três autores principais, cada um com uma obra clássica mais associada ao tema, que ainda são usados atualmente e são a base filosófica do conceito: (a) Jurgen Habermas e o livro Mudança estrutural da esfera pública (1984), originalmente publicado em 1962; (b) Hannah Arendt e o livro A condição humana (1983), originalmente publicado em 1958; e (c) Richard Sennett e o livro O declínio do homem público: as tiranias da intimidade (1988), originalmente publicado em 1943.

Habermas e Arendt costumam ser estudados em conjunto, por conta das semelhanças teóricas e por partirem de análises ligadas a sociedade grega antiga para delimitarem a esfera pública e a privada. Por outro lado, Sennett traz uma perspectiva mais marxista não-ortodoxa, focando na subida da burguesia ao poder e no seu incentivo a um estilo de vida centrado na esfera privada, em detrimento da pública. Por conta disso, apresentaremos primeiro uma consideração sobre os dois primeiros autores, seguida de alguns comentários sobre Sennett para então aproximar o debate da geografia.

Rodrigo R. H. F. Valverde (VALVERDE, 2007; p. 84) apontou que Arendt e Habermas fazem seus estudos de forma análoga: através da comparação com a sociedade grega clássica e a formação do Estado durante o período Moderno, por volta do século XVIII. Em Habermas, isso esta articulado a transformação da esfera pública e da esfera privada e a formação de uma esfera pública burguesa, aliada com a formação da grande mídia. Ele busca com isso mostrar como a burguesia tomou o poder e se consolidou como status quo tanto pela dominação política e militar, quanto pelo domínio ou manipulação dos meios de comunicação. Em Arendt, essa característica aparece articulada as noções de labor, trabalho e ação. Isso, pois a autora tem como objetivo analisar a condição humana na sociedade contemporânea e entender as origens do totalitarismo e as mudanças na esfera pública.

Arendt começou seu trabalho explicando o que seria e qual seria a relação entre labor, trabalho e ação, que são entendidos como os componentes da vita activa. Por labor a autora entendeu que ele seria "a atividade que corresponde ao processo biológico do corpo humano" (ARENDT, 1983; p. 15) e "a condição humana do labor é a própria vida"(ARENDT, 1983; p. 15). O trabalho foi identificado como a atividade de produzir bens, 
de produzir coisas artificiais, cuja condição humana é a mundanidade (ARENDT, 1983; $p$. 15). Já a ação, foi entendida como a única atividade que pode ser exercida sem mediação de coisas ou matérias: é a vida política, a vida em conjunto. Sua condição humana é a pluralidade (ARENDT, 1983; p. 15 e 16). O motivo para só a ação ser entendida como componente da política é que ela é a única que só se desenvolve em um coletivo, grupo. Ela também só consegue ser desenvolvida se todas as necessidades de sobrevivência, presentes nas outras duas esferas, forem sanadas. Nas palavras da autora:

\begin{abstract}
Todas as atividades humanas são condicionadas pelo fato de que os homens vivem juntos; mas a ação é a única que não pode sequer ser imaginada fora da sociedade dos homens. A atividade do labor não requer a presença de outros, mas um ser que 'laborasse' em completa solidão não seria humano, e sim um animal laborans no sentido mais literal da expressão. Um homem que trabalhasse e fabricasse e construísse num mundo habitado somente por ele mesmo não deixaria de ser um fabricador, mas não seria um homo faber teria perdido a sua qualidade especificamente humana e seria, antes, um deus - certamente não o Criador, mas um demiurgo divino como Platão o descreveu em um dos seus mitos. Só a ação é prerrogativa exclusiva do homem; nem um animal nem um deus é capaz de ação, e só a ação depende inteiramente da constante presença dos outros (ARENDT, 1983; p. 31).
\end{abstract}

O espaço público aparece, então, como qualquer lugar associado a concretização da esfera pública, que é o espaço da discussão política e da ação, como definida acima. Tal distinção se mostra relevante, pois nem todos os espaços de livre acesso e debate se configuram em arenas políticas, assim como nem toda discussão sob política estabelece diretamente uma ação. Isso configurou uma série de nuances para o entendimento do espaço público e de seus limites.

Habermas também analisa o espaço público de forma abstrata, como qualquer lugar onde haja discussão política, ou seja, como uma esfera pública. Tanto a esfera pública, quanto a esfera privada teriam origem grega, mas foram transmitidas para os dias de hoje a partir da versão romana. Oikos virou o relativo para a esfera do indivíduo (futura esfera privada), na qual toda a vida era baseada em uma hierarquia que delimitava fortemente as diferenças entre aqueles que ali viviam. Polis virou o relativo à esfera dos cidadãos iguais, nos quais todos teriam o mesmo direito à palavra (futura esfera pública). Seria nesta última que se alcançaria o reconhecimento público e que se desenvolveria a política. Ela se constituiria, de acordo com Habermas, em um espaço de liberdade. Nas 
obras destacadas, tanto Habermas ${ }^{1}$, quanto Arendt, desconsideravam a escravidão, as diferenças de gênero ou as limitações dos direitos dos estrangeiros.

Porém, o termo "privado" só apareceu após a metade do século XVI. Também veio desse período a separação entre esfera pública e esfera privada no sentido moderno (HABERMAS, 1984; p. 24). Pouco a pouco, segundo Habermas, a política se transformou em uma tentativa de normatizar e regular o funcionamento do Estado. Isso alterou o sentido de sua existência. Essa mudança foi atribuída tanto à subida da burguesia ao poder, quanto ao novo sistema econômico que se consolidou no século XVIII, que Habermas classificou como um capitalismo financeiro e mercantil primitivo.

O autor ainda destacou o papel do Estado como poder público. Apesar dele perder força com o passar dos anos, ainda manteve seu papel organizacional. Esse marco também foi importante, pois foi o momento onde a esfera do poder público se objetivou "numa administração permanente e no exército permanente: à permanência dos contatos no intercâmbio de mercadorias e de notícias (bolsa, imprensa) corresponde agora uma atividade estatal continuada" (HABERMAS, 1984; p. 31). Sendo assim, podemos dizer que, para Habermas, a partir do Período Contemporâneo, existiu uma esfera do poder público, representada pelo Estado, e uma esfera do setor privado, que englobaria toda a sociedade civil. A esfera pública burguesa e, por consequência, o espaço público, seriam um meio termo entre esses dois extremos. Destacamos que a esfera pública estaria subordinada ao setor privado. Porém, o espaço público, visto como espaço concreto, pertenceria tanto ao Estado, quanto a um indivíduo ou a uma corporação.

Arendt discutiu a questão da violência e sua relação com a política no passado e no presente. A autora frisou que a violência na esfera pública da Polis grega era inaceitável, pois "o ser político, o viver numa polis, significava que tudo era decidido mediante palavras e persuasão, e não através de força ou violência" (ARENDT, 1983; $p$. 35). Em contrapartida, a violência na esfera privada era aceitável, pois ela era vista como a única forma de vencer a necessidade e conseguir a liberdade e a igualdade da vida política. Assim "a polis diferenciava-se da família pelo fato de somente conhecer 'iguais', ao passou que a família era o centro da mais severa desigualdade"(ARENDT, 1983; p. 41). Quanto a essa análise, achamos que a visão da autora possui uma limitação ao não abordar a violência como um instrumento de Estado. Sobre a violência institucional, 0

1 Em obras futuras, Habermas chegou a trabalhar um pouco com questões relacionadas a minorias. 
historiador Wilson do Nascimento Barbosa busca a compreender como um instrumento de classe:

\begin{abstract}
Nos povos das primeiras sociedades havia luta pelo controle de certos ambientes geográficos, que facilitariam a sobrevivência do grupo que ali se alojasse. $\mathrm{Na}$ mesopotâmia, na bacia indo-gangética, nas montanhas do Peru, nas selvas do Congo, da Guatemala ou do Brasil, diferentes grupos humanos disputaram o acesso a certas áreas preferenciais, em que a vida podia fazer-se mais vantajosa. (...) Vê-se nas tumbas faraônicas o desfile de sua polícia, principal força repressiva anterior à criação do exército. São negros armados de bastões, com os quais a elite mantinha a ordem estabelecida. A experiência histórica havia elaborado uma sucessão interminável de formas de luta até chegar-se, há seis mil anos atrás, à experiência e ao conceito, num nível do poder político, de força policial. A força policial era, àquela época, a força de choque mais avançada da história, capaz de vistoriar cada aldeia, prender os dissidentes e assegurar o pagamento imediato dos impostos. (...) O exemplo poderia ser detalhado ao longo de toda a história da sociedade, até os tempos atuais, demonstrando que, com a crescente divisão social do trabalho, torna-se necessário, para assegurar a dominação de uma classe social, estabelecer profissões policiais e militares, com a exclusiva função de espionar, sabotar, reprimir e até eliminar fisicamente membros ou grupos das classes subjugadas (BARBOSA, 2010; p. 12).
\end{abstract}

A violência e a segurança, portanto, fazem parte dos mecanismos de dominação, ao lado dos mecanismos de direção e convencimento. Além de subjugar a classe oprimida, a classe dominante busca convencê-la que o monopólio sobre a violência é algo útil e desejável. Para isso, as camadas dominantes da sociedade buscam propagar sua visão de sociedade, a fim de auferir legitimidade para seus projetos políticos. Nesse contexto, resgatamos de Habermas a importância da imprensa e da publicidade. A imprensa passou a ter um papel fundamental na sociedade capitalista, devido a sua importância na disseminação de informação, que passou a ter caráter público. Em seus veículos, abriram-se brechas tanto para o reforço ideológico do poder em uma sociedade moderna, quanto para polêmicas públicas que questionavam o Estado, seus papéis e seus poderes. Porém, num primeiro momento, apenas um público restrito acessou esse novo fórum público estabelecido pela imprensa: ele foi destinado a quem sabia ler, ou seja, o público principal era formado por membros da burguesia (HABERMAS, 1984; $p$. 34).

Ainda, era no espaço público que se realizavam a comunicação entre as pessoas e a construção da política através de discussões. A opinião pública se formava nesse contexto. Entretanto, com o passar o tempo, a opinião pública passou a realizar-se pela figura dos "críticos". Isso fez o espaço público perder parte da sua característica fundante, 
que era a de ser o espaço da discussão direta e da autorrepresentação. Para Habermas, só a retomada da discussão política nos espaços públicos ajudaria a romper com essa situação, que acabou por tornar as pessoas submissas à ordem econômica, política e social vigente.

Uma associação geográfica entre a publicidade (e os meios de comunicação de forma geral), a questão da segurança e suas implicações espaciais pode ser vista na análise de Lucas Melgaço (MELGAÇO, 2010)². O autor parte dos conceitos de psicoesfera e tecnoesfera de Milton Santos para justificar a presença constante do discurso do medo a partir da década de 70 . Isso, pois ao mesmo tempo em que se instala um sistema científico e tecnológico (tecnoesfera), também se instala um sistema de ideias, crenças e paixões associado (psicoesfera). As materialidades e imaterialidades produzidas pelos sistemas condiciona o cotidiano. Logo, "a psicoesfera do medo aparece assim como uma precondição e uma justificativa para a instalação de uma tecnoesfera da segurança. Essa tecnoesfera diz respeito a toda forma de materialidade técnica em torno do ideal de segurança e inclui, obviamente, os processos de securização" (MELGAÇO, 2010; p. 106).

Com essa base, ele comenta que o sentimento de segurança não é proporcional aos riscos, ainda mais porque os dados de seus estudos mostram uma diminuição de crimes violentos no Brasil e em especial em Campinas (foco de sua análise). Ele também destaca que "(...) ricos e pobres temem crimes diferentes. Enquanto os ricos se assustam principalmente com o grande número de crimes contra o patrimônio, como sequestrosrelâmpago (Mapa 8), os pobres têm medo, sobretudo, dos constantes homicídios que acontecem à sua volta"(MELGAÇO, 2010; p. 107). A violência e a segurança aparecem assim como pretextos para justificar e delimitar usos exclusivos do espaço, a segregação socioespacial e a valorização imobiliária.

Sennett aponta que há personalização da política, pois na sociedade atual as pessoas no contexto urbano estão cada vez mais fechadas em grupos homogêneos, em detrimento de uma cultura mais cosmopolita. Assim como Arendt, ele vê como nocivo o fato de que assuntos do âmbito privado estão sendo levados para o domínio público. Porém, uma diferença fundamental na teoria de Sennett, é que ele trabalha com a noção

2 Embora essa discussão esteja presente ao longo de sua tese como um todo, destacamos o capítulo 3, “A militarização do espaço urbano”, como mais central. 
de morte do espaço público, na medida em que uma cultura de hipervalorização da intimidade avança sobre a esfera pública. Ainda, ele parte do Antigo Regime em suas análises para entender como uma nova cultura urbana, secular e capitalista incentivaram o esvaziamento da vida pública. Em suas palavras:

Foi a geração nascida após a Segunda Guerra Mundial que se voltou para dentro de si ao se libertar das repressões sexuais. É nessa mesma geração que se operou a maior parte da destruição física do domínio público. A tese deste livro é a de que esses sinais gritantes de uma vida pessoal desmedida e de uma vida pública esvaziada ficaram por muito tempo incubados. São resultantes de uma mudança que começou com a queda do Antigo Regime e com a formação de uma nova cultura urbana, secular e capitalista (SENNETT, 1988; p. 30).

Essa valorização da intimidade seria uma estratégia da burguesia para tirar o foco das diferenças de classe. Gradualmente, as aparências vão ganhando mais destaque no público do que os discursos ou debates. Isso, pois a aparência passou a ser sinônimo do que o indivíduo é tanto em relação a moral, quanto em relação a posição social e aspectos financeiros. Então, em um momento de expansão do comércio, do costume e do fetiche da mercadoria o silêncio em público passa a ser valorizado:

O silêncio em público se tornou o único modo pelo qual se poderia experimentar a vida pública, especialmente a vida nas ruas, sem se sentir esmagado. [...] Cresceu a noção de que estranhos não tinham o direito de se falar, de que todo homem possuía como um direito público um escudo invisível, um direito de ser deixado em paz. O comportamento público era um problema de observação e de participação passiva, um certo tipo de voyeurismo. [...] Esse muro invisível de silêncio, enquanto um direito, significava que o conhecimento, em público, era questão de observação - das cenas, dos outros homens, dos locais. O conhecimento não seria mais traduzido pelo trato social (SENNETT, 1988; p. 43).

Nesse contexto, o espaço público e a esfera pública se tornam o lugar do espetáculo. Os indivíduos passam a se organizar em grupos sociais fechados, que remetem a ideia de comunidade desenvolvida pelo sociólogo alemão Ferdinand Tönnies, de gemeinschaft e gesellschaft ${ }^{3}$. Inclusive, ao longo de sua obra, Sennett sempre faz analogias com o teatro, onde há um público que assiste e atores que interpretam.

Por fim, destacamos dois pontos que são secundários na obra do autor, mas extremamente relevantes para a geografia e o estudo do espaço público. Eles também servem de argumento para Sennett enfatizar o esvaziamento do público e o ressaltar

Essa mesma referência foi incorporada a geografia por meio do trabalho de Paulo Cesar da Costa Gomes e iremos trabalhá-la mais a frente. Em Sennett, essa relação é desenvolvida na terceira parte do livro, em especial no capítulo 10. 
como um ambiente hostil, em detrimento do ambiente privado, visto como mais seguro. $\mathrm{O}$ primeiro diz respeito a questão da migração ${ }^{4}$. Sennett aponta que a grande quantidade de pessoas migrando, principalmente, do campo para a cidade incentivou com que a burguesia os visse como uma ameaça. Isso, pois havia um desconhecimento de como essa massa de pessoas se inseriria na estrutura vigente. $O$ segundo ponto traz uma reflexão sobre o acesso ao espaço urbano. De forma mais específica, o autor faz uma crítica a lógica de transporte baseada no automóvel que, desde o seu princípio, já criava uma nova forma de lidar com o espaço público. Nas palavras do autor:

\begin{abstract}
A ideia do espaço público como derivação do movimento corresponde exatamente às relações entre espaço e movimento produzidos pelo automóvel particular. Não se usa o carro para ver a cidade; o automóvel não é um veículo para se fazer turismo - ou melhor, não é usado como tal, a não ser por motoristas adolescentes que saem para dar uma volta de carro sem permissão do dono. Em vez disso, o carro dá liberdade de movimentos; pode-se viajar sem ser interrompido por paradas obrigatórias, como as do metrô, sem mudar a sua forma de movimento, de ônibus, metrô, via elevada ou a pé, ao ir do lugar A para o lugar B. As ruas da cidade adquirem então uma função peculiar: permitir a movimentação; se elas constrangem demais a movimentação, por meio dos semáforos, contramãos, etc., os motoristas se zangam ou ficam nervosos (SENNETT, 1988; p. 38).
\end{abstract}

Como destacado acima, na perspectiva clássica e filosófica do conceito de espaço público, seu caráter morfológico não é muito destacado. A análise do espaço público como algo concreto e a preocupação sobre sua morfologia surge com os urbanistas, porém sem uma reflexão mais crítica. Como destacou o geógrafo Rodrigo R. H. F. Valverde:

\begin{abstract}
Essa outra linha de pesquisa justifica a sua importância através do estudo das formas, das funções e dos significados do espaço físico. Essa perspectiva não foi suficientemente desenvolvida pela filosofia e pela ciência política, comprometendo o alcance dos estudos sobre a noção de espaço público, ao limitá-lo a estudos abstratos de uma ordem política. Com isso, coube aos urbanistas avançar nesse sentido, estabelecendo planos de ações que tivessem como ponto inicial e ponto final a distribuição dos objetos no espaço, o impacto visual das formas, a definição dos equipamentos urbanos. Em outras palavras, a responsabilidade pela descrição e pela análise da dimensão concreta da noção de espaço público esteve originalmente ligada à prática do urbanismo, fato que trouxe consequências para a sua discussão nos dias de hoje (VALVERDE, 2007; p. 100).
\end{abstract}

Um exemplo recente de trabalho de um urbanista relacionado ao espaço público e

\footnotetext{
4 Esta temática encontra-se de forma mais explicita na primeira parte do livro, “o problema público”, mas também é
} retomada na terceira parte do livro, “A desordem na vida pública no século XIX”. 
a segurança é a dissertação de Rafael da Silva Verissimo (VERISSIMO, 2012). Com base em vários casos específicos e pontuais, o autor buscou identificar estratégias preventivas do crime e da violência em duas abordagens teóricas: a abordagem determinista e a abordagem humanista. Ainda, o objetivo último dessas medidas interventivas deveriam ser reestabelecer o espaço público como um vetor articulador indispensável à vida citadina.

É com o geógrafo citado acima, Valverde, que essa defasagem na percepção do caráter morfológico na abordagem clássica foi percebida e debatida de forma mais sistemática. Em sua tese de doutorado, Valverde discorreu sobre a definição de Espaço Público e tratou com maiores detalhes esse tema, associado ao estudo de caso do Largo da Carioca (Rio de Janeiro) e com o conceito de heterotopia de Michel Foucault. Ele apontou claramente dois problemas específicos nessa abordagem clássica, que são a negligência ou contingência da dimensão espacial sobre o espaço público e o foco na dimensão política em detrimento da dimensão social e cultural (VALVERDE, 2007; p. 88). Isso, pois "de acordo com o modelo grego, a economia, a produção, os esportes, as artes e o cotidiano, por exemplo, não deveriam se encontrar misturados com a esfera pública, e consequentemente, com a esfera política" (VALVERDE, 2007; p. 94).

Além disso, essa visão restrita do espaço público apenas como o espaço da política nos moldes gregos e livre de identificações comunitárias, também restringe bastante as análises. Isso, pois ele deixa de lado, por exemplo, toda uma discussão a respeito dos simbolismos no espaço e sua apropriação. Também se faz necessário dizer que as concepções de sociedade mudaram. Apesar de as críticas que podemos fazer ao modelo econômico vigente, os indivíduos conseguiram uma série de liberdades pessoais que mudaram as suas relações com os outros e com as coisas. Nesse sentido, por exemplo, a violência tanto na esfera pública, quanto na esfera privada, passou a ser algo negativo (embora ainda seja instrumento largamente aplicado).

Por conta do exposto acima, recorreremos a outros autores para complementar as análises, mesmo reconhecendo a importância e a contribuição da matriz clássica. Em especial, destacamos a contribuição do geógrafo americano Don Michell, no livro "The right to the city: social justice and the fight for public space", escrito em 2003. Neste trabalho, o autor parte da noção de direito a cidade, desenvolvida por Henri Lefebvre, e 
debate a questão da representação política e da acessibilidade, articulada à questão do direito institucional e das leis. Estabelece-se como pressuposto, de forma sucinta, que a cidade é um local heterogêneo onde há interação social e troca de experiências. Mas para essas trocas acontecerem, é necessário que as pessoas possam morar na cidade, ou seja, ter o direito a habitá-la. Entretanto, como vivemos em uma cidade burguesa, que é a cidade contemporânea, esse direito à cidade é alienado, pois a cidade é construída para nós, em vez de por nós (LEFEBVRE, 1991 [1969]; MITCHELL, 2003).

A partir desse pressuposto, Mitchell fez algumas considerações a respeito da importância do estudo do sistema jurídico e, mais especificamente das leis. O ponto central do argumento é que a luta por direitos produz espaços e, para o direito a cidade se concretizar, ele pressupõe a apropriação do espaço público pelas pessoas. Como no livro são apresentados vários estudos de caso, em cada um ele aborda uma faceta da relação entre Estado e sociedade civil, bem como a diferença de projetos apresentadas por cada um ou pelos diferentes grupos que os compõe. Em suas palavras:

(...) Esse direito [a cidade], como espero que fique claro no decorrer deste livro, é dependente do espaço público. Mas o que é espaço público - e quem tem direito a ele - raramente é claro e, certamente, não pode ser estabelecido de forma abstrata. Eu apresento em ordem histórica aproximada, portanto, uma série de estudos de casos conectados que exploram a relação entre exclusão social, direitos sociais e justiça social no espaço público americano. As ligações entre estes estudos são muitas, mas incluem uma preocupação com a relação entre o ativismo social e as mudanças nas leis do espaço público; o papel de atores marginalizados (trabalhadores migrantes, moradores de rua) como um foco de exclusão social; a necessidade de não apenas produzir espaço público (como tantos trabalhos em geografia estudaram), mas para ativamente toma-lo, se uma reivindicação por direitos é para ser feita; e um conjunto de questões sobre a dialética da ordem e da desordem, como é trabalhado em lugares específicos nos momentos críticos (...) (MITCHELL, 2003; p. 5 e 6 ).

Dos exemplos trabalhados por Mitchell, um que se destaca é o People's Park (Universidade de Berkeley, Califórnia, Estados Unidos). Este é uma praça, cujo histórico de disputas espaciais remonta a década de 1960 (MITCHELL, 2003; p. 106). Ela foi adquirida em 1967, pela Universidade, com a finalidade de ser um local de moradia estudantil. Devido a falta de verbas, o terreno ficou vazio por algum tempo, até que as pessoas começaram a ocupá-lo e fizeram dele um parque. Entretanto, em 1969, os projetos de criar moradias nesse espaço voltaram. Então, durante a década de 1970 e 1980, houve uma série de embates no parque, inclusive com sérios confrontos entre 
policiais e ativistas. No fim, o parque ficou abandonado e moradores de rua se apropriam dele, o que promoveu um movimento de repulsa muito grande ao espaço, a partir de 1990. A conclusão a que chegou Mitchell foi a seguinte:

(...) A própria sobrevivência do Parque do Povo em face de tantas pressões para "reforma" é um testemunho da capacidade de luta constante para se manter uma certa visão de espaço público. (...) Esta visão - e o seu oposto - pode ser entendida em condições espaciais levemente diferentes. O espaço público é, em alguns sentidos, uma utopia. $\mathrm{O}$ ideal de um espaço não mediado nunca pode ser encontrado - nem o ideal de um espaço totalmente controlado no qual o público se encontra adulado pelo esplendor do espetáculo, mas nunca esta sobre nenhum tipo de "risco"(MITCHELL, 2003; p. 233 e 234).

Nesse sentido, o autor formulou o espaço público como um lugar de conflito. $O$ espaço seria tanto física como conceitualmente disputado por projetos distintos. $\mathrm{E}$ ambos os projetos se apresentariam como utopias. De um lado, estaria a utopia do espaço inteiramente entregue ao povo, que realizaria por completo seu direito à cidade. De outro, estaria a utopia do espaço inteiramente segregado e controlado, asséptico:

\begin{abstract}
Temos, então, uma dialética. Utopias da forma espacial (nas quais o sonho de um espaço público perfeitamente ordenado, como embutido em leis contra moradores de rua ou anti-piquete é um exemplo) são "perturbadas" pelos processos sociais que devem ser postos em prática para tornar realidade a utopia. E qualquer utopia do processo social (na qual o sonho de um espaço público totalmente democrático e inclusivo é certamente um exemplo) deve inevitavelmente ser "perturbada" pela forma espacial que assume. A luta social - os tipos de lutas que fundamentam as análises dos capítulos anteriores, mesmo quando todo o foco dessas análises se concentra na análise do lado oposto da luta, a implementação de uma ordem social repressiva - continua a ser fundamental para a estruturação e formação da justiça social. E é por isso que, de acordo com Van Deusen (2002), o espaço público deve ser entendido como um indicador dos regimes de justiça vigentes em qualquer momento particular. O espaço público é, neste sentido, o espaço da justiça. Não é apenas o espaço onde o direito à cidade é objeto de luta; é onde ele é implementado e representado. É onde a utopia tanto ganha forma espacial como se torna uma mentira. Utopia é impossível, mas a luta constante em direção a ela não é (MITCHELL, 2003; p. 234 e 235).
\end{abstract}

A disputa entre os distintos projetos e visões (utopias) sobre o espaço público se expressaria em lutas sociais concretas e não no fim do espaço. Nesse sentido, a forma que os regimes sociais lidam com o espaço público e, portanto, com as disputas nele realizadas, definiriam o quão opressor é aquele regime ou não. O estudo do espaço público seria, dessa forma, o estudo: (a) dos projetos e visões que disputam o espaço; (b) das formas que a luta social se dá entorno dos distintos projetos; e (c) como o regime 
social vigente lida com essas lutas. Então, não se trata apenas de discutir se houve ou não conflitos, pois eles sempre existirão. Se trata de entender como esses conflitos foram e são tratados. A proposta de Don Mitchell nos ajuda a entender porque pode haver uma gestão autoritária dos espaços. No entanto, ainda carece de alguma ferramenta que permita analisar de forma mais sistemática como se deram os conflitos, o que os motivou, e no que resultaram.

Acreditamos que um debate sobre a territorialidade oriunda da apropriação dos grupos pode ajudar a formulação mais sistemática. Dois exemplos de geógrafos contemporâneos que tratam do tema são Paulo Cesar da Costa Gomes e Rodrigo R.H.F Valverde. O primeiro, assim como Sennett, se baseou em Tönnies para analisar o espaço público e sua apropriação, no livro intitulado A Condição Urbana - Ensaios de Geopolítica da cidade, de 2002.

Gomes concorda com a perspectiva de Arendt sobre o espaço público como o locus da política e do perfeito exercício da democracia, ou seja, estar ligado a vida pública. Ele coloca que, fisicamente, o espaço público é qualquer tipo de espaço onde haja possibilidade de acesso e participação de qualquer tipo de pessoa, como a praça, a praia e o shopping 5 . Sendo assim, embora diversos grupos possam criar territorialidades, elas só são uma forma válida de apropriação mediante um convívio pacífico. Ele pressupõem a existência de duas formas de se apropriar do espaço: uma normativa institucional, chamada de Nomoespaço, e outra comunitária, chamada de Genoespaço. Essas formas podem ou não coexistir pacificamente ${ }^{6}$.

A visão de Gomes traz para o espaço público uma certa noção de civilidade. Entretanto, práticas como a ação truculenta da polícia, a apropriação da rua como uma moradia pelos moradores de rua e os vendedores ambulantes não necessariamente seguem essas normas sociais. Acreditamos que a perspectiva de classe ou dos segmentos sociais cria pontos de instabilidade no equilíbrio da vida social. Sendo assim, trazemos como iniciativa para a reflexão a ideia de heterotopia, constituída de espaços "em que a memória politica e institucional não se apresentam de maneira decisiva, em espaços nos quais as classificações funcionais não se aplicam, em espaços nos quais as

\footnotetext{
5 Em sua obra, Gomes apresenta essa discussão ao longo do capítulo 6 "Cidadania e espaço público: o que a geografia tem a dizer?”, p. 129 a 168.

6 Uma discussão mais profunda sobre a matriz teórica e o que são os conceitos de nomoespaço e genoespaço são desenvolvidos por Gomes na $1^{\mathrm{a}}$ parte de seu livro.
} 
regras de convivência não são encontradas na civilidade e na polidez que são previstas no contrato social moderno" (VALVERDE, 2007; p. 172).

Valverde coloca essa leitura como uma terceira via de estudos sobre os espaços públicos, ao lado de uma perspectiva mais republicana (como em Gomes, Vicent Berdoulay e Iná Elias da Costa) e de uma mais marxista (como em Don Mitchell e Edward Soja). Entendemos que com a visão de espaço em disputa de Gomes, mas principalmente de Michell, pode-se entender que os espaços são apropriados pelas distintas classes, pela instituição ou pelo povo. Mas isso não é feito de forma homogênea. Cada grupo se apropria de uma forma. O espaço não é uma coisa só, mas uma coisa para cada grupo que o disputa. Daí a ideia de heterotopia: cada grupo ressignifica o espaço. O problema reside que o aparato de segurança busca normatizar a apropriação, reduzindo o espaço heterotópico em um espaço normatizado e controlado.

Para fins de análise, uma forma de entender a disputa entre os aparatos de segurança e parcelas da população na ressignificação do espaço público é através do conceito de territorialidade humana, de Robert Sack. Para ele, um espaço geográfico pode ou não ser um território, a depender do grau de controle exercido por forças sociais que com ele interagem. A definição de Sack é bastante elucidadora:

\begin{abstract}
Neste momento, deixe-me definir explicitamente o que quero dizer por territorialidade: a tentativa de um indivíduo ou grupo $(x)$ de influenciar, afetar, ou controlar objetos, pessoas, e relações (y) através da delimitação e estabelecimento de controle sobre uma área geográfica. Essa área é o território. Note que: (...) a área geográfica pode se referir a áreas fixas ou móveis, e $X$ não precisa estar no território para exercer controle sobre ele. (...) há diferentes formas pelas quais a territorialidade pode ser garantida, incluindo o direito legal sobre a propriedade da terra, normas culturais, e proibições sobre o uso da área.(...) Normalmente, os territórios ocorrem de forma hierarquizada, e como parte de uma hierarquia organizacional mais complexa (SACK, 1983; p. 56 e 57).
\end{abstract}

Essa definição de Sack nos permite entender, para fins de análise, a disputa pelo espaço público do centro expandido da cidade de São Paulo como a disputa pela formação, ou dissolução, de territórios. As forças de segurança do Estado podem ser entendidas como agentes sociais que visam estabelecer o espaço público urbano como um território do Estado, cuja função social é previamente determinada pelo Estado e suas forças de segurança. Essa mesma força busca coibir o uso do espaço público para fins políticos e culturais não aprovados previamente. Note que há, portanto, o estabelecimento 
de uma hierarquia: só é aceitável manifestações que hajam sido aprovadas pelo status quo, através de seus agentes sociais que exercem (ou tentam exercer) o controle sobre o espaço geográfico urbano. Por outro lado, os distintos grupos e práticas sociais que são criminalizados disturbam a territorialidade do centro, seja ao estabelecer uma nova territorialidade (quando o movimento hip hop ressignifica uma praça ou uma rua, por exemplo), ou seja criando não territorialidades (quando movimentos políticos utilizam o espaço público como locus do conflito político).

Então, o conceito de territorialidade permite entender o sentido da disputa na qual o Detecta está. Se os aparatos de segurança lutam para estabelecer o espaço público urbano como territórios sob seu controle, tanto o videomonitoramento utilizado como ferramenta de coerção, como a propaganda em torno dele utilizado como ferramenta de modelação de comportamentos fazem parte da criação de um tipo de arquitetura urbana de sitiamento. Daí a necessidade de entender o que é a modelação de populações, no contexto da sociedade de controle. 


\section{VIDEOMONITORAMENTO \\ INTELIGENTE \\ COMO \\ UMA FERRAMENTA DE CONTROLE}

Nas ciências sociais, os estudos sobre videomonitoramento raramente se limitam aos aspectos técnicos da instalação de câmeras de segurança. Em geral, eles buscam refletir sobre o impacto imediato e de longo prazo na organização espacial e política dos diferentes grupos sociais. Muito da literatura sobre o tema tem como matriz de pensamento as reflexões de Foucault e a sociedade da disciplina, que dialoga com Jeremy Bentham e a ideia do panóptico, ou seja, a possibilidade de vigilância constante. No entanto, atualmente, uma nova corrente vem ganhando espaço. Trata-se dos estudos inspirados na contribuição de Deleuze e Guatarri sobre a sociedade de controle, em especial nas observações feitas no Post-Scriptum Sobre as Sociedades de Controle (DELEUZE, 1992).

A literatura se divide entre aqueles que acreditam que a sociedade de controle é um tipo de sociedade de disciplina, e aqueles que acham que se trata de um novo tipo de sociedade. Seja como for, Deleuze apontou que atualmente os mecanismos de controle social não se baseiam mais em mecanismos de disciplinarização em massa. Ao contrário, baseiam-se na personalização das ferramentas para grupos amostrais, o que inclui a adequação das políticas aos nichos sociais. Isso significa dizer que parte das políticas públicas não são universais, mas sim adequadas a determinados grupos populacionais ou localidades específicas.

Para a organização do espaço urbano, isso significa que a modelação de comportamentos cria territorialidades, onde apenas alguns comportamentos e são aceitáveis, e certos grupos sociais podem ter sua participação no espaço limitada. Não visam constituir uma disciplina única, mas sim modelar os agentes sociais para que os mesmos operem dentro de determinados comportamentos tolerados. Não se deseja eliminar o contraditório, mas sim o modelar para que ele passe a cumprir um papel previsível na reprodução da estrutura social vigente, nem que seja como inimigo público. Um exemplo de criação de inimigo público foi o caso da "criação" da Sininho, figura mítica criada em torno de Elisa Quadros Pinto Sanzi, em 2013, no Rio de Janeiro. 
Elisa Quadros foi uma militante política muito ativa entre o segundo semestre de 2013 e o primeiro trimestre de 2014. Participou dos movimentos autônomos Ocupa Cabral $^{7}$ e Ocupa Câmara, onde enfrentaram, conforme palavras dos militantes daqueles movimentos, algumas das máfias mais perigosas do Rio de Janeiro. Entre 2013 e 2014, parte dos atos ocorridos no Rio de Janeiro terminavam em enfrentamento entre a Polícia Militar e militantes que adotavam a tática Black Bloc (tática de enfrentamento direto disperso e sistemático contra a polícia).

Elisa Quadros jamais foi adepta da tática Black Bloc, e não foi flagrada, em qualquer momento, atuando na resistência direta contra a Polícia Militar. Tão pouco era liderança de qualquer movimento formal. Ainda assim, a mídia a retratou como Sininho (seu codinome no movimento Ocupa Cabral), a líder dos Black Blocs. Elisa foi perseguida e ficou foragida da polícia. Foi uma das indiciadas no "processo dos 23", processo que buscava criminalizar militantes supostamente ligados ao "movimento Black Bloc"8. Segundo Elisa, aquilo que era um codinome em um movimento social se tornou uma espécie de símbolo a ser criminalizado para desmoralizar o movimento a qual supostamente pertencia. Em uma reportagem à A. Pública, ela explicou:

\begin{abstract}
Quanto mais você vai peitando, mais você vai sendo destruída. Foi o que aconteceu comigo. Se eu tivesse abaixado a cabeça, não acredito que a criminalização ia diminuir. Você cria um símbolo. Essa pessoa não precisa fazer mais nada, vai continuar sendo citada. Eu fui citada no estupro coletivo [ocorrido no morro da Barão em maio de 2016]. Eu estou arrolada no processo. Também foi citado [na coluna do] Ancelmo Góis que eu estava influenciando a molecada a ocupar as escolas, a ocupar a Secretaria de Estado da Educação [Seduc]. Eu não sei nem onde fica a Seduc! Agora o processo do Santiago está andando, e onde fala do caso do Santiago eu sou citada. (...) Eu não tenho absolutamente nada a ver com isso. Tanto que nem no processo estou. Eu conhecia o Fábio, o Fox, da ocupação, mas era mais um menino que estava lá. Nunca tinha visto o Caio na minha vida. Eu estava presa dentro da Central do Brasil, presa pelos policiais. A polícia estava espancando as pessoas: criança, idoso, mulher, homem... De manhã, um amigo que é jornalista, que tinha sido amigo dele [de Santiago], estava com olho inchado, vermelho, me abraçou assim: "Cara, um amigo meu vai morrer". Me abraçava e chorava. (...) O maior erro que cometi foi ter ido na delegacia quando o Fábio se apresentou. Eu acordei de manhã com umas amigas minhas, apavoradas, falando que o Fábio tinha se entregado. E o que a gente fez? Começou a ligar para [o pessoal dos] direitos humanos. (...) A morte do Santiago significa uma dor que eu não consigo imaginar para a família dele. Mas tudo o que eles precisavam era eu ir para a delegacia. Porque aí eles pegam a criação
\end{abstract}

Movimento que denunciava Sérgio Cabral Filho por corrupção. Em novembro de 2016, Sérgio Cabral Filho foi preso.

8 O “movimento Black Bloc” é uma criação midiática e policialesca. O Black Bloc é uma tática de enfrentamento contra a polícia, e não um movimento. Não possui ideologia, não possui hierarquia, reuniões, lideranças, nem qualquer característica necessária para que seja classificado como movimento. 
midiática da liderança e juntam com o maior caso da destruição dos movimentos sociais que estava acontecendo. A mídia é muito mais poderosa do que a prisão. (A. Pública: "Meu nome não é Sininho", 13 de Abril de 2017)

Embora se trate de um exemplo do Rio de Janeiro, o ocorrido é emblemático o suficiente para entendermos que existe relação entre o comportamento dos meios de comunicação, forças de segurança, e interesses do Estado. Diante de interesses comuns, atuam juntos na criação de símbolos que permitem construir uma narrativa útil a criminalização de inimigos em comum. Isso passa por modelar o comportamento tanto dos militantes como da população que acompanha os acontecimentos pelos telejornais. Induz-se o público e os próprios militantes ao erro. Elisa, que não era liderança, passou a ser tratada pela mídia e pela polícia como se o fosse. O próprio movimento passou a tomá-la como símbolo da resistência, e ela mesma, conforme depoimento dado em 2017, cometeu o erro de se sentir responsável pelos seus companheiros de militância, se expondo como algo que não era. Em São Paulo, o esforço por criar a imagem de um líder dos Black Blocs teve menos sucesso. No entanto, não faltaram esforços por parte da Secretaria de Segurança Pública do Estado de São Paulo de ligar o Movimento Passe Livre (MPL) aos Black Blocs, como forma de criminalizar o MPL. O próprio Alexandre de Moraes, então secretário da SSP, afirmou, em janeiro de 2016: "As lideranças do Movimento Passe Livre acobertam os black blocs. As lideranças têm ligação com essas pessoas e isso será investigado".

O que desejamos demonstrar é que existe um esforço de modelação de comportamentos da população como parte da disputa pelo espaço público. Parte da mídia, dos aparatos de segurança do estado, e agentes privados que tem em comum a utopia de um espaço público asséptico, atuam pela transformação do espaço público, em especial as regiões centrais e as regiões nobres da cidade de São Paulo, em um território sob tutela das forças de segurança. Parte das ferramentas utilizadas para isso são aquelas que visam afetar o subjetivo da população.

No presente capítulo será discutido como a teoria da sociedade de controle pode servir para interpretação da relação entre videomonitoramento, política de segurança e controle social e territorialização. Dessa forma, deseja-se entender qual a relação entre política de segurança e a forma que os grupos sociais e políticos se relacionam com o 
espaço público, em especial para consolidação do mesmo como território, no sentido dado por Robert Sack. Visa-se com isso trazer para o debate uma linha de pensamento que não é tradicionalmente tratada como parte do cânone dos estudos da relação entre segurança pública e espaço público. Antes de adentramos na contribuição de pesquisadores que refletiram diretamente sobre a sociedade de controle, é útil primeiro retomar alguns aspectos importantes da relação entre prevenção ao crime, controle social e controle geográfico. Dois autores que refletiram sobre o tema foram David Garland e John Lowman.

Ao longo do presente capítulo, serão feitas indicações da relevância da teoria discutida para o objeto da pesquisa, o projeto Detecta. Visa-se com isso entender o Detecta, que foi um projeto de instalação de videomonitoramento inteligente ${ }^{9}$ no Estado de São Paulo, como parte daquilo que os foucaultianos denominam tecnologia de poder, ou, para alguns deleuzianos, tecnologia de controle. Visa-se, portanto, apresentar uma chave interpretativa para se refletir sobre o papel dos projetos de videomonitoramento inteligente como ferramentas de controle social e espacial.

\title{
1.1 CRIME, VIGILÂNCIA E PODER
}

David Garland definiu parte das teorias criminológicas que atualmente guiam o funcionamento das políticas de segurança pública como "criminologias da vida cotidiana". Em seu trabalho "The Culture of Control", apresentou uma breve definição e análise da consequência da adoção das políticas pensadas segundo essa lógica:

\begin{abstract}
as teorias criminológicas da vida cotidiana abordam a ordem social como um problema de integração de sistemas. Não são as pessoas que precisam ser integradas, mas os processos e os arranjos sociais que eles habitam. Em vez de abordar os seres humanos e suas atitudes morais ou disposições psicológicas, as novas criminologias agregam as partes componentes de sistemas e situações sociais. Eles consideram a forma como as diferentes situações podem ser redesenhadas de modo a gerar menos oportunidades de crime, como os sistemas de interação (sistemas de transporte, escolas, lojas, áreas de lazer, habitação...) podem ser feitos para abranger maneiras de criar menos fraquezas de segurança ou pontos críticos criminológicos. Para esses quadros, a ordem social é uma questão de alinhamento e integração das diversas rotinas e instituições sociais
\end{abstract}

9 Chama-se de videomonitoramento inteligente o uso de CCTV agregado de softwares de análise de imagem, capaz de identificar padrões. Isso inclui (a) rostos e perfil fisionômico; (b) objetos e letras; e (c) padrões de movimento. No caso do Detecta, o software prometido em abril de 2014 deveria incluir a capacidade de identificar padrões de comportamento e indivíduos procurados, através do cruzamento da imagem com um banco de dados da Secretaria de Segurança Pública do Estado de São Paulo. Trata-se de tecnologia análoga a já instalada pela Microsoft na cidade de Nova Iorque. 
que compõem a sociedade moderna. É um problema de assegurar a coordenação - fazer com que os trens funcionem a tempo - não de construir um consenso normativo. (...) (GARLAND, 2002; p. 183)

De acordo com essa definição, as atuais políticas de segurança se caracterizam pela compreensão que o crime pode ser limitado através da cautelosa manipulação do ambiente social onde ele ocorre. Na geografia, essa relação, entre controle do ambiente e formas de vida, já foi estudado por alguns autores relevantes. Na escola de Chicago, por exemplo, a cidade é um organismo, como um ecossistema composto por diferentes partes que competem entre si pela sobrevivência. A cidade, assim, é palco de diversos focos de conflitos entre diferentes grupos identitários fracionados no espaço, que formam territorialidades competitivas em conflito, que podem ou não adquirir legitimidade na estrutura da cidade (VALVERDE, 2007).

Em um contexto de arquitetura de guerra, conforme análise proposta por Graham (GRAHAM, 2011) a legitimidade ou não de um território de um grupo social pode passar pela adequação do mesmo ao status quo que se deseja estabelecer. Postura e formas de apropriação podem ser toleradas ou consideradas nocivas para o controle que as forças de segurança desejam realizar. Quando nocivos, passam a ser excluídos e mesmo perseguidos. Nesse sentido, o controle do ambiente significa transformar um espaço público em território, onde parcelas da população, que teoricamente deveriam ter livre acesso ao mesmo, passam a ser excluídas (SACK, 1983)

Conforme Firmino e Duarte (2015), o videomonitoramento já está encorporado no cotidiano da cidade como instrumento controle sobre $\mathrm{O}$ ambiente, auxiliando $\mathrm{O}$ monitoramento de dados e criando uma nova camada de territorialidade na cidade. A aliança disso com a tecnologia moderna permitiu a criação de aplicativos de celulares e outras plataformas que lembram as pessoas desde o momento em que devem beber água até quando o ônibus vai passar. Essas chamadas tecnologias de smartcity criam uma segunda camada territorial, digitalmente pensadas com base nas apreensões e codificações da informação. O fluxo de informações criados nessa segunda territorialidade, podem servir também para manipulação dos comportamentos dos usuários dos aplicativos que compõe a smartcity (FIRMINO e DUARTE, 2015). Trata-se de tema relevante, uma vez que o próprio sistema Detecta, desde sua $4^{a}$ fase, em 2016, tem como uma de suas pontas o uso de aplicativos pelos policiais para monitoramento de 
rua e rodovias. O aplicativo, sinaliza sempre que um veículo registrado como envolvido em crime é detectado pelo sistema de reconhecimento de placas de automóveis. Levado ao extremo, se essa tecnologia fosse capaz de identificar comportamentos e rostos, poderia ser usado para limitação de acesso de grupos sociais inteiros ao espaço público, o que faz parte da criminologia da vida cotidiana. Inclusive, Garland continua:

Tal abordagem se enquadra facilmente nas políticas sociais e econômicas que excluem grupos inteiros de pessoas, desde que a segregação desse tipo faça com que o sistema social funcione mais facilmente. Também tem afinidades óbvias com políticas de "tolerância zero", que tendem a ser associadas à repressão de baixo nível, ao uso discriminatório dos poderes policiais e à violação das liberdades civis dos pobres e das minorias. Por outro lado, não é impossível imaginar uma versão socializada da prevenção da criminalidade situacional, na qual os grupos vulneráveis mais pobres são providos de recursos de prevenção da criminalidade e níveis melhorados de segurança comunitária, embora esse esquema exija que essa criminologia seja desacoplada dos imperativos comerciais e das configurações de mercado com as quais muitas vezes é associada (GARLAND, 2002; p. 183).

Essa definição elucida a atual forma de ligação entre segurança, poder e espaço. Não só o sistema de segurança pública reforça o poder político, como passa a depender do mesmo para a adequada preparação do ambiente social. Quando o que se combate não é exatamente o crime, mas sim o potencial criminoso, abre-se portas para um modelo de segurança pública excludente ${ }^{10}$. Isso significa consolidar o caráter asséptico de determinados espaços públicos. Alguns locais devem estar submetidos à completa normatização. O piche, a ocupação irregular, a atuação política, não devem fazer parte cotidiana desses locais. Caso contrário, o controle do ambiente pode se perde, em especial em sociedades altamente heterogêneas econômica e socialmente, onde há uma cisão entre camadas dominantes e camadas subalternas.

A hipótese de que a política de segurança pública de São Paulo segue a teoria criminológica da vida cotidiana é corroborada por afirmações como a do ex-comandante da Polícia Militar de São Paulo (Coronel Camilo) à ocasião da regulamentação da Lei 16,049 (Lei Anti-Pancadão): "Quando não tem som alto, não junta pessoas, não há comércio de bebidas, tráfico de drogas e sexo com menores. (...) O policial vai poder agir

10 Não se trata de ignorar a necessidade da ação preventiva no combate ao crime, mas de entender o significado e impacto da referida prevenção dentro do contexto da sociedade brasileira, onde a cultura e a política são objetos de criminalizações esporádicas. 
no início. A lei cumpre essa lacuna. Hoje, se o policial for chamado, não pode fazer nada" (Jornal G1: Alckimin regulamenta lei que proíbe pancadões no Estado de São Paulo, 16/03/2017). Nesse contexto, pode-se entender o Detecta como um programa que não se resumia ao auxílio ao policiamento do crime ocorrido. Na verdade, o mesmo pode ser entendido como parte da preparação do ambiente social para a "prevenção do crime". Essa preparação do ambiente passava por fazer-se saber que o Detecta era implantado, buscando assim desestimular as práticas criminosas em locais sob vigilância. Em parte, isso só seria possível se acompanhado por alguma espécie de punição para aqueles que fossem captados cometendo um crime. Como o Detecta jamais foi efetivamente implementado em larga escala, sua eficácia ficou bastante prejudicada. A não implementação plena do Detecta chegou a ser alvo de relatórios do TCE, incluindo o relatório 17.941/026/2015, e na análise das contas de 2016 do governo do Estado de São Paulo (aprovadas com ressalva em junho de 2017). Segundo os relatórios, o Detecta não pode ser considerado um software de videomonitoramento inteligente.

No entanto, a própria existência e divulgação do projeto Detecta visou desestimular determinados tipos de apropriação do espaço público. Em especial aquelas que foram objeto da atuação experimental do detecta: a atuação política, entendida como ação cuja finalidade é a realização ou reivindicação de uma pauta específica ou geral. Divulgou-se, na época, a intenção do uso do videomonitoramento inteligente para localizar focos de conflitos e auxiliar a polícia no combate às práticas violentas nas manifestações (Brasil 24/7: "Mesmo em teste, Detecta ajudou a coibir caos em SP", 17/09/2014). Uma parte considerável das ações eram contra o patrimônio, como destruição de lixeiras e pichações.

É possível interpretar essa divulgação da intenção como parte da preparação e controle do ambiente contra aqueles que visavam uma apropriação política do espaço público das ruas de São Paulo, em especial do centro expandido. Não se buscou, com o videomonitoramento, combater os excessos e quebras das leis dos diversos grupos, mas sim de um específico, que de alguma forma questionava o status quo e destruía parte de seu patrimônio. Além disso, não devemos esquecer o caráter midiático do Detecta como ferramenta política de um de seus maiores defensores, o atual ministro do Supremo Tribunal federal brasileiro Alexandre de Moraes, mas que foi secretário da Secretaria da Segurança Pública do Estado de São Paulo entre 2014 e 2016. Conforme ressalta David 
Garland, no mesmo trabalho, algumas páginas antes: A segunda característica distintiva dessas medidas é que são populistas e
politizadas. As medidas políticas são construídas de forma a privilegiar a opinião
pública sobre os pontos de vista de especialistas em justiça criminal e elites
profissionais. Os grupos profissionais que uma vez dominaram a comunidade de
formulação de políticas estão agora cada vez mais privados de direitos. A política é
formulada por compromissos de ação política e assessores políticos - não por
pesquisadores e funcionários públicos. As iniciativas políticas são anunciadas em
ambientes políticos - a convenção do partido, a conferência do partido, a entrevista
televisionada. Eles estão encapsulados em frases de efeito estáticas: "A prisão
funciona", "Três strikes e você está fora", "Verdade na sentença", "Sem prisões-
férias", "Ação dura contra o crime, e dura contra as causas do crime". Muitas
vezes, essas iniciativas são pouco pesquisadas e não possuem análise de custos
e as projeções estatísticas que são características padrão em outras áreas da
política (GARLAND, 2002; p. 140 e 141).

Atualmente, conforme o autor, parte significativa da elaboração dos programas de segurança visa responder as demandas eleitorais (ou políticas, em geral). Isso significa dizer que ela não é desenvolvida, ou aplicada, pela eficácia que atinge na ação sobre o crime (homicídios, sequestros, entre outros), mas pelo apoio político que angaria junto aos eleitores (ou a agrupamentos políticos) pelo controle da dissensão. Nesse sentido, o Detecta foi, também, um programa aparentemente perfeito vendido para parte do público como uma suposta salvação.

O uso da sensação de segurança como ferramenta modificadora das políticas e das formas de apropriação do espaço já foram objeto de pesquisa de outros estudos, incluindo a obra "Securização Urbana: da psicoesfera do medo à tecnoesfera da segurança", por Lucas Melgaço; e "Fobópole", por Marcelo Lopes de Souza. O que vem se observando, em estudos do gênero, é que o medo da insegurança pública vem servindo tanto para formação de condomínios fechados e ampliação da atuação de segurança privada como para a ampliação da vigilância das forças de segurança pública. Pode-se dizer, portanto, que o medo tem sido utilizado como sentimento motivador para transformação de espaços urbanos em territórios, dentro da concepção de Robert Sack. Ou ainda, tem fortalecido a força da utopia da assepsia do espaço público.

Ao apresentar o Detecta, Alexandre de Moraes angariou apoio de parte do corpo político que (a) defende a modernização tecnológica do Estado; (b) que a segurança depende da vigilância sobre os cidadãos (comuns); e (c) que o espaço público é o local da ordem normatizada. Evidentemente, não foi apenas o Detecta que o alavancou 
politicamente para seu futuro cargo de Ministro do Supremo Tribunal Federal. Mas não é possível descartar a hipótese que o programa foi antes pensado pelo apoio que angariaria do que pela eficácia possível, ou pela possibilidade de sua instalação.

Nada disso invalida a compreensão que o Detecta foi utilizado, ainda que midiaticamente, como ferramenta de disputa sobre o espaço público (o que será mais amplamente discutido no capítulo 3 da presente dissertação) ${ }^{11}$. Ao contrário, o fato de ter servido para angariar apoio político demonstra existência de um projeto político para o espaço público onde a assepsia é um objetivo importante. Caso contrário, nenhum apoio político seria angariado. A própria escolha do local e dos alvos para o suposto uso experimental $^{12}$ do Detecta demonstra o caráter ambiental e político da segurança em São Paulo13. É importante ressaltar que o problema da manipulação do ambiente e de atividades sociais como forma de evitar possíveis crimes se torna ainda mais prejudicial pela ausência de qualquer projeto democrático de planejamento urbano que vise ampliar a participação das populações na vida pública urbana. Conforme ressaltou John Lowman, a lei tem um forte aspecto ambiental:

Mesmo quando as análises associativas são usadas como base para pesquisas sociais mais intensiva (Herbert e Evans 1973; Herbert 1976; Evans, 1980), os efeitos do controle social em áreas diferentes nas taxas de crime e delinquência raramente são considerados. Isso não quer dizer, no entanto, que os geógrafos perderam completamente a importância da forma como o controle social estrutura os ambientes humanos. Davidson (1981) e Herbert (1982) incluem revisões do

11 A título de exemplo, em fevereiro de 2018, a Associação dos Amigos do Alto de Pinheiros (SAAP) anunciou a assinatura de um convênio com a SSP para integração de 15 câmeras doados pela associação ao sistema Detecta. Em seu sítio de internet afirmava: "Na prática, significa uma maior prevenção e um combate mais eficaz de ações criminosas na região". No entanto, na mesma notícia, explica que o Detecta localizaria o uso de veículos cadastrados como participantes de ações criminosas. A função de leitura de placa de carros é a única que atualmente funciona no Detecta. Vê-se que há dissociação entre o anunciado como intenção e aquilo que o sistema realmente é capaz de fazer. A notícia dá a impressão de que o Alto de Pinheiros se tornará mais facilmente monitorado pela polícia. Uma leitura cautelosa deixa claro que apenas será mais fácil a localização de veículos suspeitos, ou a eventual identificação de criminosos após a realização do crime. Ver: http://www.saap.org.br/seguranca/saapassina-convenio-inedito-com-secretaria-de-seguranca-e-cameras-de-alto-dos-pinheiros-terao-conexao-direta-comas-policias-paulistas/

12 Alexandre de Moraes, enquanto secretário da segurança, sempre afirmou que a implementação do Detecta estava em andamento, sempre que questionado. Atribuía ao Detecta boa parte do videomonitoramento realizado em São Paulo.

13 Outro exemplo do caráter ambiental da atuação da Polícia de São Paulo e uso de videomonitoramento está na resposta dada por Alexandre de Moraes à pergunta: "ao que se deve atribuir o sumiço dos Black Blocs que não apareceram às duas grandes manifestações na cidade de São Paulo (...) o que a polícia fez?”. A resposta foi: “nas duas últimas manifestações (...) para garantir que houvesse qualquer infiltração, qualquer problema quanto a isso (...) esse controle foi feito em todas as estações do metrô. Nos fizemos com todas as câmeras do metro. Algumas pessoas, 3, 4, 5 organizados que poderiam eventualmente estar se dirigindo para causar baderna, como aqueles 20 carecas do subúrbio foram, elas eram abordadas para ver se estavam armadas. (...) por isso até eu pedi para os dois jogos serem antecipados, para não ter jogo no dia, se não fica muito difícil o controle no metrô". Vê-se que parte do combate aos Black Blocs envolveu o uso de videomonitoramento para interceptar suspeitos, e houve adiamento de jogos de futebol para facilitar a atuação da polícia. Note que não se buscou combater a atuação de criminosos, mas de interceptar manifestantes que aparentassem ser suspeitos. (RODA VIVA, 13/04/2015). 
trabalho de Damer (1974), Baldwin, Bottoms e Walker (1976) e Gill (1977) sobre o efeito da política da polícia e da autoridade habitacional sobre o desenvolvimento do problema áreas de crime, particularmente em termos de rotulagem como tal por pessoas de fora. Esses estudos em sociologia e criminologia se concentram no papel dos "porteiros urbanos" e dos meios de comunicação no aumento da aparência da criminalidade em tais áreas.

Tomando uma abordagem totalmente diferente, Kress (1980) mostra como a lei em si é um atributo ambiental importante. A lei classifica o espaço para que algumas atividades sejam criminosas somente se ocorrerem em determinados lugares. Estas mesmas distinções também influenciam a atividade de aplicação da lei, de modo que o comportamento criminoso realizado em privado é muito mais provável que passe despercebido do que a mesma atividade em um espaço público (ver Stinchcombe, 1966) (LOWMAN, 1986; p. 83).

Lowman (1986) se referia à normatização legal sobre determinados comportamentos que permitiam que certas ações fossem crime em um local, e não em outro (como fumar em espaço fechado, entre outros), e ao modo de aplicação da lei, que vigia uma localidade, mas não a outra. No caso de São Paulo, onde o sistema de segurança não é eficiente no combate ao crime, a distinção de tratamento da polícia de acordo com o local onde se encontra é notória.

A proposta do Detecta em nada modificou essa diferenciação territorial dos crimes "toleráveis". Caso aplicado em sua totalidade, significaria a vigilância constante sobre os pichadores, sobre os movimentos de sem teto, sobre o movimento do hiphop e skatistas, tidos como grandes perturbadores da ordem no centro expandido ${ }^{14}$. Ainda, reforçaria o centro expandido como local prioritário da vigilância, apesar de não ser a área da cidade que concentra maiores indicadores de violência real. Isto é, o centro expandido seria o local de exercício pleno do poder do Estado e de maior regulamentação da política.

A relação entre o poder e segurança é bastante autoevidente, pois, nas sociedades modernas, o Estado possui o monopólio legal da violência. No entanto, a análise da relação entre as políticas de segurança e o controle social não é intuitivo. Demanda certa reflexão, já bem ressaltada por Lawman, em 1986:

A relação entre crime e controle é tão fundamental que deve ser preocupante, não importa o que a epistemologia informe a geografia do crime. Podemos especificar o relacionamento de várias maneiras em uma variedade de níveis de abstração desde o fenômeno imediato até o esotericamente metafísico, reconhecendo que, em última análise, uma perspectiva puramente fenomenalista não pode ser sustentada por causa da natureza espúria da distinção entre categorias observacionais e teóricas (ver Gregory 1978, capítulo 2). O desenvolvimento inicial de uma geografia unificada de crime e controle, levando ao desenvolvimento de

14 A hipótese da criminalização e uso de videomonitoramento para perseguição de elementos considerados perturbadores se baseia em leis como a "lei antipichação" (PL 56/2005, do município de São Paulo), a "lei antipancadão",(PL 455/2015, do Estado de São Paulo), a "lei antiterrorismo" (PL2016/2015, do governo federal). 
uma geografia de controle social, pode prosseguir em várias dimensões (algumas das quais já estão bem articuladas na criminologia convencional): (1) análise da produção de estatísticas de crime; (2) desenvolvimento de medidas alternativas de desvio; (3) exame de tipos alternativos de desvio; (4) estudo do crime e controle de deslocamento; e (5) investigação da expressão espacial de controle (LOWMAN, 1986; p. 88).

O que o trecho ressalta é que a unidade entre a geografia da segurança e a geografia do controle leva à formação de uma geografia do controle social. O que está pressuposto por trás dessa proposta é que a associação do poder e da segurança, quando estudado em seu caráter territorial, levam ao estudo do controle (que é sempre social). Caso se aceite essas proposições, chega-se à conclusão de que as políticas de segurança não se resumem aos seus objetivos declarados, mas se estendem aos seus efeitos sociais e territoriais e às razões políticas de sua adoção.

Para a presente pesquisa, essa percepção permite buscar entender o Detecta não apenas como um programa pontual (que jamais chegou a ser implantado plenamente), mas como um episódio de uma disputa social e política mais ampla pelo controle territorial (e moral) sobre as ruas de São Paulo. O Detecta, portanto, deve ser analisado também pelo apoio que angariou, e pela visibilidade atingida em parte da mídia, assim como pela percepção de parte dos agentes sociais que eram alvos potenciais do dito programa.

\subsection{CONTROLE E SOCIEDADE}

A passagem da vigilância e punição individuais como ferramenta de amoldamento da sociedade faz parte do que Deleuze chamou de sociedade de controle. Sobre as novas ferramentas de modulação da sociedade, Deleuze afirmou:

O estudo sociotecnológico do mecanismo de controle, apreendido em sua cúpula, teria que ser categórico e descrever o que já está em processo de substituição para os locais disciplinares de cerco, cuja crise é proclamada em toda parte. Pode ser que os métodos mais antigos, emprestados das antigas sociedades de soberania, voltem à tona, mas com as modificações necessárias. O que conta é que estamos no início de algo. No sistema prisional: a tentativa de encontrar penalidades de "substituição", pelo menos para crimes menores e o uso de coleiras eletrônicas que forçam o condenado a ficar em casa durante certas horas. Para o sistema escolar: formas contínuas de controle, e o efeito na escola de perpetuação, o abandono correspondente de toda pesquisa universitária, a introdução da "corporação" em 11 níveis de escolaridade. Para o sistema hospitalar: o novo medicamento "sem médico ou paciente" que escolhe potenciais pessoas doentes e sujeitos em risco, o que não é de modo algum atestar a 
individuação - como a palavra -, mas substitui o corpo individual ao numérico do código de "divíduos" materiais a serem controlados. No sistema corporativo: novas maneiras de lidar com dinheiro, lucros e seres humanos que já não passam pela antiga fábrica (DELEUZE, 1992; p. 7).

No trecho, Deleuze destacou o sistema prisional, em vez de discutir a segurança pública como um todo. Ele buscou comparar as prisões tradicionais ao sistema de monitoramento eletrônico e a prisão domiciliar. No entanto, foi ao se referir ao sistema de saúde, que destacou uma passagem muito mais importante no novo modelo de gestão de políticas públicas: ao invés do Estado lidar com problemas pontuais, apresenta políticas de prevenção geral. Na medicina, controla a doença através do estudo de população de risco, o que faz sentido para algumas doenças. Podemos dizer que, na segurança, o processo é similar, mas a diferença é que o que se combate é o comportamento "criminoso" ou grupos identificados como perturbadores da ordem. Mesmo na ausência de crimes concretos a serem investigados, os esteriótipos são criados e perseguidos.

Pode se dizer que a chamada criminologia da vida cotidiana, conforme definição de Garland, encaixa-se dentro daquilo que Deleuze chamou de sociedade de controle ${ }^{15}$. As políticas públicas têm como princípio a modulação da sociedade de tal forma que o problema desapareça ou submerja para longe dos olhares públicos. Nesse sentido, uma política de vigilância tem a tripla função de: (a) vigiar diretamente para facilitar a punição ao crime; (b) levantar informação estatística sobre o público, permitindo formulação de políticas mais eficazes; e (c) levar ao público a percepção que a política está sendo tomada como reforço positivo, para aqueles que anseiam pela segurança, ou negativo, para aqueles que buscam a espontaneidade e apropriação coletiva do espaço.

Em tese, a principal característica do Detecta era que ele seria capaz de identificar situações de risco, permitindo a atuação imediata da polícia e a alocação de efetivo de acordo com as necessidades identificadas. Para isso, dependia de um vasto e crescente banco de dados, e de forte poder de processamento computacional. Não se trata, portanto, apenas do videomonitoramento, mas também da formação de vasto banco de dados. Para Alexandre de Moraes, o programa não era apenas o software que a Microsoft

15 Ao se aceitar a tese de Garland que a criminologia da vida cotidiana deseja modificar as relações sociais existentes em dadas regiões como prevenção ao crime (se combatendo abstratamente a possibilidade de ocorrência de crimes), e ao se aceitar que uma das características da sociedade do controle é que as políticas públicas são voltadas para o controle situacional e de agrupamentos sociais (e não mais para o controle dos indivíduos), então a consequência é que a criminologia da vida cotidiana pode ser explicada pela lógica da sociedade do controle. 
produziria, mas sim a rede de vigilância e o banco de dados resultante do desenvolvimento e instalação do software. Quando a Microsoft falhou em entregar aquilo que havia sido prometido (conforme relatório do TCE já citado), o sonho da vigilância inteligente não desapareceu por completo. Tão pouco o anseio pelo estabelecimento de um espaço público livre de "perturbações" e "perturbadores".

Outro aspecto relevante da teoria da sociedade de controle que pode ser aplicada à análise do projeto Detecta é a divisão binárias dos agentes sociais. Essa tese deriva da leitura dialética marxista sobre a sociedade. No entanto, dá ênfase na artificialidade (e funcionalidade) da divisão, conforme explicou Lazzarato:

\begin{abstract}
Mas a realização das relações de poder não é apenas integração, é também diferenciação: as relações de poder são exercidas na medida em que existe uma diferença entre as forças. No capitalismo, essa diversidade, em vez de ser uma diferenciação de diferença, o desdobramento da multiplicidade, é uma criação e reprodução de dualismos, dos quais os mais importantes são os dualismos de classe (proletários / capitalistas) e sexo (homens / mulheres).

Os agrupamentos binários, como sexos e classes, devem capturar, codificar e controlar as virtualidades, as possíveis variações das assembleias moleculares, as probabilidades de interações da cooperação neomonadológica. As classes realizam a redução da multiplicidade aos dualismos e a um todo coletivo que totaliza e unifica singularidades irredutíveis. $O$ conceito de classe trabalhadora designa um todo coletivo e nota um conjunto distributivo (LAZZARATO, 2006; $p$. 174).
\end{abstract}

O trecho de Lazzarato tem como fundamento o conceito deleuziano de assembleia. De forma simplificada, trata-se da percepção que os agentes sociais se organizam em torno de identidades e regras próprias de acordo com seu locus social e histórico. O autor chama a atenção para o fato de que as relações de poder se realizam tanto pela integração social, como pela diferenciação social. A coesão de um grupo reside na oposição do mesmo a um outro. A divisão é evidentemente uma abstração que visa formar grupos opostos, nos quais existem diferentes subgrupos. Daí a divisão binária sempre conotar coletivos e conjuntos distributivos ao mesmo tempo. O conceito é fundamental para a compreensão da sociedade de controle. Um exemplo didático é a divisão da sociedade entre esquerda e direita, que só existem em oposição uma a outra. No ceio da esquerda existe uma gama de grupos (identitários, políticos, socioeconômicos) que muitas vezes disputam entre si. O mesmo ocorre na direita. ${ }^{16}$ A existência de divisões binárias revela, portanto, os interesses políticos e sociais daqueles que formulam

16 Trata-se de divisão análoga àquela formulada pelos leninistas, onde além de classes sociais existem segmentos de classes e grupos políticos que formam o chamado "quadro de forças". 
utilizando as divisões em questão como chaves interpretativas.

Para nossa análise, a divisão binária mais pertinente é aquela largamente utilizada pelos jornais e políticos conservadores ao tratar de políticas de segurança: o bandido (ou vândalo) em oposição ao cidadão (cidadão de bem, ou bens). De um lado estão todos aqueles que, no espaço público, agem de acordo com as regras normatizadas pelo Estado. Àqueles que não possuem "nada a temer". Do outro, estão todos aqueles que não se submetem às regras, seja por atuarem conforme regras formuladas pela comunidade local, ou por simplesmente romperem as regras estabelecidas. Por bandidos (ou vândalos), entende-se traficantes, trombadinhas, pichadores, manifestantes 'radicais', camelôs sem licença, entre outros. A divisão revela o interesse por parte daqueles que defendem a apropriação asséptica do espaço: criminalizar, vigiar, isolar, e intimidar todos aqueles que se apropriam do espaço conforme regras não sancionadas pelo Estado. $\mathrm{Na}$ prática, coloca desde assaltantes, que rompem as regras sociais para realizar ganhos individuais, até skatistas, que apenas utilizam o espaço público para realização de uma atividade de lazer nem sempre autorizada previamente pelos administradores do espaço.

Ao se afirmar que o Detecta tem como intuito identificar situações de risco, afirmase, com palavras mais suaves, que o software utilizado teria como uma de suas funções identificar linguagem corporal, agrupamento de pessoas, vestimentas, entre outros. Para que isso seja possível, determinados comportamentos sociais devem antes ser classificados como potencialmente nocivos para sociedade. A única forma de o fazer é em contraste ao comportamento "esperado". Evidentemente a aglutinação de jovens em uma esquina formando uma roda de conversa, com objetos sólidos em mãos (como skates), é uma situação de risco apenas quando comparada à função esperada da esquina: servir como local de passagem, apenas destinada à pedestres em deslocamento. $\mathrm{O}$ uso de videomonitoramento para identificação de supostas lideranças não é novidade. Em 2014, por exemplo, Geraldo Alckmin, então Governador do Estado, afirmou que as câmeras de vídeo do metrô seriam usadas para identificar a suposta atuação de grupos organizados em um tumulto ocorrido nas estações de metrô entre da Sé e Pedro II:

Eu não acredito que essas coisas sejam geração espontânea. Eu acho que precisa ser investigado, verificar as câmeras de vídeo, qual a origem disso. $O$ fato é que houve um problema numa porta resolvido em menos de dez minutos e que acabou causando esse grande transtorno para a população em razão da ação 
inicial de um grupo de pessoas e depois de vândalos que acabaram atacando estação, trens e destruindo patrimônio. (O Globo: "Alckmin diz que vândalos foram responsáveis por ação no metrô", 05/02/2014).

Nesse contexto, portanto, a própria classificação das situações, e formação do banco de dados de situação de risco, depende da divisão binária entre "cidadão de bem" e "vagabundo" (ou qualquer outra terminologia adotada). Representa, sem precisar se afirmar abertamente como tal, uma visão de mundo onde toda e qualquer apropriação espontânea do espaço público é um risco, e só pode ter sido motivada por lideranças más intencionadas. Visa moldar os indivíduos através, também, do controle sobre o espaço público.

A tese de que parte da disciplina é interiorizada pelos agentes da sociedade não é nova. Em Foucault, já se lê semelhante afirmação. Conforme Mark Kelly, teria ocorrido apenas uma mudança na intensidade da interiorização da disciplina e na intensidade das tecnologias de poder. As novas ferramentas de controle, portanto, não significariam verdadeira mudança na tecnologia de poder:

Claro, Deleuze está certo de que as coisas mudaram nas últimas décadas. É na natureza das coisas sempre mudar. A questão é em que medida eles estão mudando, se as mudanças são quebras em algum aspecto, e, em caso afirmativo, como vou sustentar que as mudanças recentes identificadas por Deleuze foram de intensidade e não de tipo, pelo menos em relação às tecnologias de poder, conforme descrito por Foucault.

Foucault, por seu lado, não define a disciplina sucintamente, mas ele a caracteriza consistentemente de maneira diferente de Deleuze. Ele a entende como distinto do poder soberano antigo que operava por corpos prejudiciais, como moldar e cultivar corpos. Por esse motivo, ele usa a frase "anatomo-política" (isto é, "política corporal") como sinônimo de disciplina. Isso não para no corpo, no entanto, em vez disso, ele argumenta em Disciplinar e Punir que o poder disciplinar produz uma "alma" com base no corpo. Isso significa que pode haver "disciplinas consensuais", nas quais os disciplinados se identificam e aceitam sua disciplina (KELLY, 2015; p. 154 e 155).

Mark Kelly entende que a tese da existência de uma sociedade de controle baseada na modulação dos agentes não difere essencialmente da sociedade de disciplina que gera a interiorização da ordem determinada através do biopoder. Mas pode-se entender que a modulação do indivíduo não se resume apenas à interiorização de condutas esperadas. Isto é, não é apenas o ato de transformar o indivíduo em ser 
produtivo da sociedade. É também a contínua indução de comportamento dos agentes disruptivos. A sociedade de controle modula ambos os lados das relações binárias, uma vez que induz determinado tipo de comportamentos esperados para aqueles que se opõe à normatização da sociedade.

Essa diferença entre interiorização da disciplina e modulação do ser social é essencial para entender como o videomonitoramento (e o videomonitoramento inteligente) atua na constituição de um outro tipo de sociedade. Uma câmera de segurança pode ter como impacto (a) induzir os cidadãos a se comportarem dentro da lei onde as câmeras existem; ou (b) realizar suas atividades contraventoras em locais onde a as câmeras não estão instaladas. Parte-se de que a mudança geográfica da ação "criminosa" pode ser induzida pelo videomonitoramento (ou por outras técnicas de vigilância e policiamento). Voltamos, portanto, à definição geográfica do crime. Pode-se vigiar alguns espaços públicos estratégicos, e deixar outros sem vigilância. Conforme a tese de modulação deleuziana, trata-se de criar "barreiras" e "portões", que levam os indivíduos a limitarem seu deslocamento geográfico de acordo com sua identidade e seu comportamento. Ao não se vigiar um local público, como é o caso dos espaços periféricos, cria-se um espaço que reúne a contravenção, diminuindo a pressão sobre as regiões onde a assepsia é vista como fundamental. O resultado seria que a percepção do crime e da violência como um todo teria tendência de diminuição pela gestão espacial da vigilância.

Ainda, mesmo a divulgação da ideia do videomonitoramento inteligente pode gerar mudança de comportamento. Manifestantes mais radicais tendem, sob a hipótese de fácil identificação, a usar vestimentas que dificultem sua identificação positiva. Usam máscaras, lenços, roupas que cubram tatuagens, entre outros. Carregam seus "utensílios" de combate em mochilas, buscando só se cobrir no curso da manifestação. O que começa como forma de se proteger de eventual identificação e punição legal, se transforma em um instrumento de identidade de grupo (OLIVA, 2017; p. 94). Ao o fazerem, se tornam facilmente classificáveis com vândalos ou black blocs pela polícia militar (ou mesmo por jornalistas), antes mesmo de iniciarem qualquer espécie de enfrentamento. Mesmo o uso de mochilas em dias de manifestação se torna ato suspeito. Assim, ao se divulgar a vigilância (quase) total, um comportamento paranoico pode ser induzido, facilitando a classificação sumária de agrupamentos políticos. Trata-se, portanto, não exatamente da interiorização da disciplina, mas da modulação do comportamento. $A$ 
diferença entre modulação como ferramenta de controle e a disciplina é que esta última permite entender como as chamadas operações psicológicas funcionam.

A vigilância pode ser uma ferramenta que faz parte do controle social através da modulação dos indivíduos. Mas para isso, depende de um comportamento da sociedade, e de quem está no poder, que trate os seus membros como grupos, ou variáveis, a serem tratadas em geral, e não como indivíduos a serem doutrinados. Maurizio Lazzarato deixou claro o que significa esse tratamento modular dos grupos e subgrupos sociais:

Na escravidão mecânica, o indivíduo já não é instituído como um "sujeito individuado", "sujeito econômico" (capital humano, auto empreendedor) ou "cidadão". Em vez disso, ele é considerado uma engrenagem, um componente nas assembleias dos "negócios" e do "sistema financeiro", na assembleia de mídia e na assembleia do "estado de bem-estar" e suas instituições coletivas (escolas, hospitais, museus, teatros, televisão, internet, etc.). A escravidão é um conceito que Deleuze e Guattari emprestaram explicitamente da cibernética e da ciência da automação. Significa a "gestão" ou "governo" dos componentes de um sistema. Um sistema tecnológico escraviza ("governa" ou "gerencia") variáveis (temperatura, pressão, força, velocidade, saída, etc.), garantindo a coesão e o equilíbrio do funcionamento do todo. A escravidão é o modo de controle e regulação ("governo") de uma máquina técnica ou social, como uma fábrica, empresa ou sistema de comunicação. Ele substitui a "escravidão humana" dos antigos sistemas imperiais (egípcio, chinês, etc.) e, portanto, é um modo de comando, regulamentação e governo "assistido" pela tecnologia e, como tal, representa uma característica específica do capitalismo.

Deleuze descreve precisamente os tipos de subjetividade sobre os quais este aparelho de poder dual controla. Subjeção produz e sujeita indivíduos, enquanto que na escravização "[i]ndivíduos se tornam 'divíduos', e as massas se tornam amostras, dados, mercados ou" bancos" (LAZZARATO, 2014; p. 24 e 25).

Lazzarato ressaltou o tratamento estatístico das massas como parte fundamental do controle social. Para que possa haver modelação e indução, é necessário que cada indivíduo se transforme em um componente do banco de dados, e assim possam fazer parte de uma amostra. Os grupos sociais se tornam, dessa forma, variáveis a serem calculados. Podem ser variáveis explicativas (quando o pertencimento a um grupo é fator para se prever o comportamento de determinado subgrupo) ou explicadas (quando se deduz que uma pessoa é parte de um grupo devido ao seu comportamento). Em ambos os casos, a preocupação não é o de realizar controle absoluto sobre um indivíduo, mas sim o de tratar do grupo como um todo.

Para a presente pesquisa, a visão deleuziana ressaltada por Lazzarato permite 
chegar a algumas chaves interpretativas relevantes: (i) a transformação do indivíduo em estatística leva a desindividualização das políticas públicas, incluindo as de segurança; e (ii) ao passo que os indivíduos passam a pertencer às amostras, uma mesma política pública possa ser moldada para afetar de forma distinta grupos sociais diferentes. Do ponto de vista da disputa do espaço público, mais importante do que punir e controlar o comportamento dos indivíduos, se torna fundamental determinar o locus e formas de atuação dos grupos sociais e políticos. A relação entre local de atuação e grupo social é relevante para (a) tratá-lo como variável explicativa no cálculo das ações institucionais, quando se considera, por exemplo, em quais estações de metrô serão realizadas vistorias de transeuntes em dias de manifestação; e (b) tratá-lo como variável explicada, quando, por exemplo, visa-se induzir que o comércio ambulante ilegal não se concentre na frente de estações de metrô, mas atue livremente em certas estações de ônibus na periferia. Note-se que essa observação está de acordo com a proposta de Robert Sack a respeito da formação da territorialidade, que é um espaço geográfico em que uma força " $x$ " exerce controle, limitando a ação das demais forças " $y$ ".

No caso do Detecta, portanto, pode-se formular a hipótese que a apresentação do seu projeto ao público tinha como objetivo induzir comportamentos mesmo antes de sua aplicação. Daí o esforço por parte da Secretaria de Segurança do Estado de São Paulo de dar amostras de como ele funcionaria mesmo antes de sua implementação. Ao passo que trazia a sensação de segurança para parte da população, incentivava o discurso de tipo paranoico entre aqueles que até a véspera apenas queriam a democratização do espaço público.

Essa leitura de que a vigilância faz parte de um mecanismo mais complexo de controle e modulação dos grupos sociais não é novidade na literatura sobre segurança. Nikolas Rose, por exemplo, já levantou uma reflexão pertinente sobre o tema, ao buscar entender a relação entre as políticas públicas e o controle social:

Em nossas sociedades de controle, não se trata de socializar e disciplinar o assunto $a b$ initio. Não se trata de instituir um regime em que cada pessoa permaneça permanentemente sob o olhar alienígena do olho do poder que exerce a vigilância individualizadora. Não é uma questão de apreensão e de normalização do infractor ex post facto. A conduta é continuamente monitorada e remodelada por lógica imanente em todas as redes de prática. A vigilância é "projetada" nos fluxos da existência cotidiana. Nestes circuitos de inclusão, a modulação calculada de conduta de acordo com princípios de otimização de impulsos benignos e 
minimização de impulsos malignos é dispersa ao longo do tempo e espaço da vida comum. Este não é um ensaio da tese sociológica talvez primeiro proposto por $\mathrm{E}$. A. Ross, que, em 1894, anotou 33 maneiras pelas quais a sociedade exercitou o controle social. . . [e então] procedeu a desenvolver esses pensamentos preliminares sobre os princípios organizadores da sociologia ": a afirmação de que os controles informais sobre a conduta são exercidos em todas as áreas da vida social (Kay 1993: 22-3; ver Ross 1901; Hamilton e Sutton, 1989 : 14-15, Lumley 1925; Rose 1999: 120-4). Para o que aqui se relaciona é a instrumentalização e o aprimoramento das características de controle que são potenciais em toda uma variedade de práticas no serviço ou projetos específicos para o gerenciamento de conduta (ROSE, 2000; p. 325).

Nikolas Rose ressaltou duas questões bastante importantes. Primeiro, na sociedade de controle, as condutas não precisam ser previamente disciplinadas. Ou seja, não se trata de criar uma repressão toda poderosa que faça desaparecer as condutas sociais consideradas nocivas. Na verdade, deixa-se margem para que uma mesma conduta possa ser considerada nociva ou saudável, a depender da situação. Um exemplo disso é a divisão (algumas vezes arbitrária) entre Grafiti e Pichação. Também não se trata da punição após o ato. Isso é, o mais importante para o controle social não é punir os indivíduos para os reeducar e reinserir na sociedade. Em segundo, na sociedade de controle, a própria vigilância deixa de ser importante como ferramenta de controle ativo, e passa a fazer parte de procedimentos difusos de indução. Mesmo as ferramentas de vigilância se tornam mais difusas. Evidentemente, isso tem se tornado cada vez mais verdade em uma sociedade onde drones de monitoramento são utilizados pela polícia, e celulares são rastreados através do sistema de georreferenciamento embutido na maioria de seus aplicativos.

Isso significa que o videomonitoramento moderno, incluindo mas não se resumindo ao videomonitoramento inteligente, deve ser estudado pela totalidade do projeto de qual fazem parte. O projeto Detecta possui características específicas e distintas de outras iniciativas também aplicadas na cidade de São Paulo. Essa especificidade reside na proposta do Detecta, na sua forma de divulgação, no destaque que recebeu nos jornais de grande circulação, e como distintas parcelas da população o perceberam. Daí a necessidade de estudar o videomonitoramento através da repercussão da divulgação dos projetos de segurança de qual fazem parte.

O projeto City Câmeras, da prefeitura de São Paulo, iniciado durante a gestão João Dória Jr., não propõe a integração da vigilância com um banco de dados de "pessoas de 
interesse". No entanto, visa a integração entre a vigilância privada e a pública. Enquanto o projeto Detecta se destacava por abrir portas para o controle social direto sobre grupos sociais previamente selecionados, o projeto City Câmeras facilita a atuação da polícia em favor de empresas privadas. Enquanto o objeto principal do Detecta era o controle "total" sobre o espaço público, o City Câmeras facilita a atuação da polícia na investigação de crimes ocorridos no interior ou nas adjacências de empresas privadas parceiras da prefeitura. O projeto City Câmeras foi também criado em uma gestão do PSDB, partido de Geraldo Alckmin. Dória foi o candidato à prefeitura de São Paulo apoiado por Geraldo Alckmin, e por Alexandre de Moraes, que declarou desde 2015, em entrevista à Roda Viva de abril daquele ano, que apoiaria quem Alckmin indicasse.

\subsection{DISCURSO E SOCIEDADE}

A relação entre discurso e vigilância não pode ser encarada como uma via de mão única. Isto é, não se pode achar que o discurso é apenas uma arma utilizada por quem lança uma política pública a fim de maximizar os efeitos da mesma. Na verdade, a percepção sobre as políticas públicas, incluindo as de segurança, estão sempre em constante disputa. Os diferentes grupos constroem narrativas e buscam divulgá-las em um contexto de diversificação de plataformas de conteúdo. Ainda, os próprios mecanismos de divulgação favorecem determinadas narrativas em detrimento de outras. Esse favorecimento pode ocorrer racionalmente, o que abordaremos mais detalhadamente nos próximos capítulos, ou como subproduto da organização da mídia. Em uma sociedade de controle, a modulação através da propaganda incessante nem sempre resulta em um discurso racional e direto, previamente pensado. Depende da multiplicação de argumentos não racionais, como parte de um processo de criação de falsos consensos.

$\mathrm{Na}$ verdade, é pressuposto para que a sociedade seja de controle (e não de disciplina), que as apropriações dos discursos sejam relativamente caóticas mesmo se influenciadas pelos meios de divulgação. Como pressuposto, parte-se da compreensão de que televisão, o rádio, o jornal impresso, e a internet possuem impacto diferente sobre seus espectadores. A velocidade na difusão das informações, a capacidade de verificação de fontes, a possibilidade de edição e reorientação de conteúdos parece condicionar a 
experimentação das plataformas e suas forças discursivas. Exatamente por isso, as políticas públicas possuem tanto mais sucesso quanto possam ser apropriadas de forma distinta pelos meios de veiculação. Não se trata apenas de utilizar as políticas em peças de marketing, mas de elaborá-las de tal forma que sua descrição técnica seja condizente com uma narrativa que se deseja promover. Assim, a própria política, que deveria ser voltada a solução de um problema, à busca pela correção do problema em sua raiz, se torna instrumento da criação discursos. Quando se fala de políticas de segurança, por exemplo, um governo pode criar uma política para fazer parecer que o problema da insegurança é maior do que realmente é, em busca de ampliar um futuro leque de ações do próprio espaço, justificando a segregação e controle sobre o território (SOUZA, 2008). O Detecta, nesse sentido, foi também pensado e modificado ao longo do tempo para adaptá-lo ao discurso que se pretendeu divulgar. A adaptação das políticas públicas para facilitar um discurso que se pretende fazer não é novidade. David Garland chamou a atenção, por exemplo, que a televisão pressionou os políticos para um comportamento mais populista:

\begin{abstract}
A dinâmica das conferências e entrevista televisivas também tornou mais difícil para os administradores e profissionais evitar a força emocional da opinião popular. Ao contrário da audiência no Congresso ou da comissão de inquérito, a entrevista televisionada coloca regularmente a racionalidade do "sistema" diretamente contra o agravo de pessoas feridas pelas políticas do sistema. $\mathrm{Na}$ verdade, a TV mudou as regras do discurso político. A TV - com sua rapidez sônica, sua intensidade emocional e seu público de massa - tendeu a pressionar os políticos a serem mais populistas, mais emotivos, mais evidentemente em sintonia com o sentimento público. O espectro do derrotado Michael Dukkakis, com seu liberalismo supostamente "suave sobre o crime" e seu idioma tecnocrático muito racional, lançou uma longa sombra sobre o debate político nos EUA e além (GARLAND, 2002; p. 157).
\end{abstract}

Conforme David Garland, a mídia moderna favorece discursos emotivos, em detrimento de argumentos racionais e técnicos. O favorecimento de discursos facilita a ascensão de políticos de perfil também não técnico. Como uma de suas consequências, as próprias políticas públicas implementadas em temas de grande apelo nacional são formulados não por sua potencialidade efetiva, mas pelo impacto emotivo que possa vir a ter. Ou seja, são desenvolvidos, apresentados, e implementados, de acordo com sua capacidade de ser propagandeado. A política pública, assim, torna-se também uma peça de marketing. Não pode ser avaliada, portanto, apenas por seu impacto técnico. É 
necessário estudar qual foi o impacto midiático das mesmas. Onde foram propagandeadas, quais foram as promessas feitas, como os jornalistas a receberam, entre outros.

A mudança das regras da política e da formulação da política pública, resultante também dos novos espaços de publicidade dos discursos, resulta em um novo tipo de relação entre debate público e espaço público. A percepção emotiva sobre as políticas aplicadas em dadas localidades têm impacto direto sobre a apropriação realizada pela população sobre o espaço em questão. Nesse sentido, o rádio, a televisão, e a internet, ao potencializar a comoção não racional sobre as políticas públicas, gera reações dramaticamente espacializadas. Pessoas de camadas de renda distintas, de círculos de convivência distintos, absorvem a informação de forma distinta. Isso significa dizer que uma política pública ao ser pensado para uma camada social específica, também favorece imediatamente o discurso social que favorece aquela camada.

No caso da presente pesquisa, deve-se entender que o Detecta não foi apenas uma política que visava modelar a opinião pública, mas foi também resultante da defesa irracional da possibilidade da constituição de uma utopia asséptica sobre o espaço. $O$ sonho do controle total sobre todo indivíduo que transita no espaço público, a identificação facial de suspeitos, e a previsão de situações de risco, está além da capacidade computacional e de processamento atualmente existentes. No entanto, como objetivo último, fortalece, ainda que temporariamente, a pressão social para que a apropriação do espaço público seja realizada dentro da normatização prévia realizada pelo Estado. Ao buscar atender os anseios emotivos pela anulação dos elementos perturbadores (mesmo que sua implementação seja inviável), o Detecta fortaleceu os mesmos anseios, ainda que temporariamente. Criou-se uma pressão para a aceitação de regras sociais como se fossem consensuais. O caso típico foi o suposto uso do Detecta para a repressão de membros de movimentos de sem teto, pela ocasião da reintegração de posse em setembro de 2014 (caso que será tratado no terceiro capítulo dessa dissertação). Trata-se do fortalecimento de uma ilusão de um consenso social sobre as normas vigentes, que facilita a implementação das regras que outrora podiam ser objeto de contestação. John Lowman forneceu esclareceu a relação entre normatização e formação de consenso social: 
O argumento de que existe um consenso social claro sobre um grupo básico de leis criminais coloca problemas para qualquer posição de conflito extremo (embora a maioria das posições de conflito reconheça o consenso de opinião sobre certas leis). Mas esta observação por si só não é suficiente para negar que há desacordo sobre a composição adequada do direito penal, particularmente quando se trata de leis relativas a drogas, aborto, moralidade sexual, delinquência e leis na fronteira entre jurisdição civil e penal. A aparência do consenso sobre certas leis também pode ser ilusória se, de fato, o consenso for ideologicamente produzido. Nos termos de Gramsci, o consenso sobre certos tipos de leis refletia processos hegemônicos. Na escrita de Gramsci, o termo "hegemonia" refere-se à dominação ideológica como, por exemplo, na forma como a burguesia estabelece e mantém seu governo não apenas pela força, mas através do consentimento ativo da cidadania (Bottomore 1983, 201-3). A regra da lei torna-se uma parte importante da construção da hegemonia burguesa (ou consenso). Por exemplo, há evidências de que certas leis da droga, em vez de partir de qualquer consenso público, realmente criaram o consenso (Small 1978). E, embora a definição de assalto parece bastante óbvia, a linha entre roubo e lucro é menos clara (LOWMAN, 1986; p. 84).

Lowman argumentou que algumas leis não derivam de consenso social. Ao contrário, são justamente instrumentos de construção posterior do dito consenso. Ao discursar sobre a relação entre lei e hegemonia, chamou a atenção para o fato das normas não serem apenas o coroamento de um tipo de controle social, mas serem uma ferramenta de formação do mesmo. Lowman, em outro trecho, também chamou a atenção para o fato das leis possuírem caráter territorial. Havendo as normas de conduta caráter territorial, isso é, sua aplicação e significado dependem de local onde a conduta se realiza, a construção da hegemonia também significa controlar quem pode fazer o que e aonde.

A construção da hegemonia depende também da construção de discurso em cima das normas propostas e de sua aplicabilidade. No Brasil, têm-se que algumas leis são "letra morta", pela inviabilidade de aplicação. Essas leis, ao não serem aplicadas (ou pior, aplicadas apenas contra uma parcela da população, como no caso do consumo e tráfico de drogas), tornam-se contestáveis, diminuindo a capacidade de hegemonia daqueles que governam o país. Uma política pública que visa fortalecer a capacidade da sociedade de localizar e punir infratores é também um instrumento de construção de hegemonia.

Nesse sentido, é bastante significativo que o Detecta tenha ganhado destaque num momento de efervescência social: desde a segunda metade de 2013, e em 2014, o Brasil observou acirramento das mobilizações sociais, com ampliação da participação de 
adeptos da tática Black Bloc. O enfrentamento entre polícia e Black Blocs ia para além dos conflitos de rua, se desdobrando em investigação policial (OLIVA, 2017). Pode-se argumentar que, no discurso, o projeto tinha como parte de sua função a de reafirmar o caráter de nomoespaço (GOMES, 2002), um espaço cujas as regras de comportamento são rígidas e formalmente determinadas com o aval do Estado, das vias e praças públicas de São Paulo. Foi uma forma de tentar construir um consenso social a favor da utopia de assepsia do espaço público. Na prática, a normatização da conduta no espaço público depende ou da capacidade real do Estado impedir a apropriação espontânea do mesmo, ou da construção de falsos consensos através da proposição esporádica de projetos que aglutine parte da população em oposição à "contravenção".

Uma das características da disputa moderna pela hegemonia é a saturação do debate, de forma a retirar do foco os aspectos técnicos e diminuir as implicações de princípio existentes nos projetos de políticas públicas. Daí a necessidade de fazer suceder um projeto após o outro, ainda que o anterior não haja sido aplicado. Ainda, pode-se ressuscitar projetos abandonados por sua impossibilidade de aplicação. O importante é garantir que o assunto esteja sempre em pauta, mas com flexibilidade de adaptação do projeto para cada guinada de opinião (ou contestação técnica) que possa vir a aparecer. Trata-se de sufocar o debate em uma miríade de opiniões e discussões. Maurizio Lazzarato chamou a atenção para essa técnica de exclusão do público através da inclusão do mesmo nos debates:

A batalha travada por intermitentes sobre a fala, as categorias e os discursos correu contra uma nova estratégia e novas técnicas semióticas: silenciar o não especialista, o "cidadão" e o público fazendo-os falar; providenciar a exclusão deles, fazendo-os participar; mantenha-os à distância, consultando-os, ouvindo suas queixas através de um exército de jornalistas, especialistas e pesquisadores. Vivemos em um "mundo comum" projetado pela semiótica do marketing, publicidade, consumo, televisão e Internet. $O$ acesso a esta semiótica compartilhada não é apenas negado, é imperativo: é preciso unir-se, é preciso participar ativamente. A exclusão do governado e a neutralização de seu discurso singular resultam da inclusão de sua forma de expressão dentro de um determinado espaço semiótico comum. Nas sociedades de vigilância, a escassez de discurso não é o problema, mas sim a superabundância, o consenso e o conformismo que a sua circulação pressupõe e produz.

O espaço público está saturado de uma circulação de sinais, imagens e palavras e com uma proliferação de mecanismos de sujeição que, ao mesmo tempo que incentiva e solicita fala e expressão, evita expressões singulares e neutraliza processos heterogêneos de subjetivação. Para que o discurso singular seja possível, a comunicação compartilhada deve primeiro ser interrompida, é preciso deixar a conversa infinita do consenso da mídia, forçar rupturas no espaço público, assim como, para "ver", é preciso remover-se do incessante bombardeio de 
clichês visuais. Em outras palavras, para que exista politicamente e exista, em vez de entrar no mundo comum, o último deve ser singularizado, isto é, é preciso impor a diferenciação existencial e política criando novas divisões. A especificidade de um mundo comum, sua singularidade e sua diferença devem ser afirmadas "na época em que os efeitos de nivelamento da informação e da participação social são reforçados todos os dias". Singularidade, divisão e diferença não são adiantadas: eles devem ser inventados e construídos (LAZZARATO, 2014; p. 141 e 142).

Lazzarato opõe o modelo da mídia de massa da época da sociedade de disciplina a um novo modelo de debate público na sociedade de controle. Na primeira, a mídia era usada como ferramenta de um discurso único. Todo argumento contrário era atacado através de uma linguagem técnica e opiniões de senso comum, que desqualifica a divergência. Todas as opiniões diferentes, de grupos variados dentro da sociedade, eram então silenciadas. A propaganda, por isso, precisava ter certa consistência, uma vez que a desqualificação do discurso opositor só era possível mediante um discurso oficial convincente para massa que o recebia. A construção do discurso único dependia da constante reafirmação dos mesmos valores. Na sociedade de controle, a tecnologia de poder mudou.

Em vez de tentar fornecer um discurso único, se objetiva criar uma multiplicidade de fragmentos de discursos que cheguem a conclusões similares. Trata-se de dissolver o debate técnico e estável entre comentários de opinião. A propaganda, nessa nova era, não precisa ser mais consistente. Um mesmo projeto pode mudar de nome para ser reapresentado apenas para manter o debate sobre o tema em alta. Ainda, um mesmo nome pode servir para designar projetos completamente distintos, mas apresentados como se fossem o mesmo. O importante é que, ao se manter o debate ativo, jamais se discuta seus aspectos técnicos mais importantes, nem o princípio por trás deles. Isso porque não se trata mais da aplicação do projeto específico, mas sim de justificar mediante os olhos públicos uma visão de mundo que se pretende hegemônica.

Pouco mais adiante, Lazzarato fala da importância da construção da narrativa do medo como mecanismo para que um processo social já conhecido seja apresentado como nova solução para a insegurança construída pela narrativa. $O$ faz ao discutir a oposição entre emprego e desemprego(LAZZARATO, 2014; p. 158). No entanto, pode-se aplicar sua conclusão ao problema da organização do espaço público. Quando se trata de 
combater determinadas condutas consideradas disruptivas da ordem, uma forma comum é a apresentação da mesma como fonte (ou porta de entrada) de um mal maior. Assim, cria-se um medo artificial que justifica a repressão de uma conduta que de outra forma seria visto como arbitrária. Ainda, a existência de uma proposta de solução para um suposto problema funciona como reforço positivo para tese que o problema realmente existe.

A existência de comerciantes ambulantes ou estandes de venda informais em algumas vias do centro não apresenta risco social óbvio à população. No entanto, argumenta-se que a venda ilegal de produtos está ligada à pirataria e falsificação de produtos, que por sua vez estaria ligada ao tráfico de drogas, que se liga por sua vez ao tráfico de armas. Nessa linha de argumentação, afirma-se que a "pirataria" realizada por ambulantes financia a violência urbana. Daí a necessidade do Estado possuir uma política de combate aos comerciantes informais.

A prova de que o governo realmente se preocupa com o combate ao financiamento da violência urbana é que ele tem projetos para vigiar as vias públicas, e os utiliza contra o comércio irregular. $O$ combate à pichação tem significado similar: afirma-se que a pichação é depredação e atentado ao meio ambiente. A prova disso é que o Estado combate os pichadores. Forma-se o raciocínio tautológico que se existe uma proposta de solução para um problema, é evidentemente porque o problema de fato existe. E se ele existe, a solução precisa ser aplicada.

Assim, a existência de projetos de videomonitoramento que visam impedir determinados tipos de apropriação do espaço público funciona como reafirmação de que aquele comportamento é nocivo. O Detecta, portanto, pode ser lido também como uma ferramenta de reafirmação do caráter criminal da pichação, da manifestação política radical, da apropriação espontânea e orgânica do espaço público. A repercussão do Detecta, portanto, deve ser lida também como parte da execução do poder político do governo. Se o programa original do Detecta jamais foi plenamente aplicado, como jargão ele foi largamente utilizado.

Na prática, a própria divulgação do programa criou e cumpriu sua principal função: a de criar a sensação que o videomonitoramento inteligente organizará, de uma vez por todas, todo espaço público. Nesse sentido, é mais importante como discurso do que como 
projeto concreto. A subjetividade do discurso, no entanto, não significa a ausência de efeito concreto na organização do espaço. Conforme lembra Michael Hardt e Antonio Negri, o discurso produz subjetividades que passam a integrar o próprio funcionamento do poder, não apenas o servindo como propaganda mas também o organizando como fenômeno concreto:

O poder, como produz, organiza; Enquanto organiza, fala e se expressa como autoridade. A linguagem, à medida que se comunica, produz mercadorias, mas também cria subjetividades, coloca-as em relação e ordena-as. As indústrias de comunicações integram o imaginário e o simbólico dentro do tecido biopolítico, não apenas colocando-os ao serviço do poder, mas integrando-os em seu próprio funcionamento (HARDT \& NEGRI, 2000; p. 32 e 33).

\subsection{CONTROLE E TERRITÓRIO}

O conceito de territorialidade humana de Robert Sack nos permite entender como a sociedade de controle influencia a disputa pelo espaço público. Apesar de o espaço público ser caracterizado pelo direito constitucional de livre acesso, e pela sua natureza de copresença como fator fundamental de sua classificação como espaço público, os mecanismos de controle social nele operam de forma cotidiana. O policiamento, a vigilância, a discriminação, e até a arquitetura do espaço, influenciam a forma de apropriação da população, para além do local onde o controle se exerce diretamente. Há função social renovada para o espaço público por intermédio da sociedade do controle, que é condicionar o comportamento divergente dos cidadãos e limitar o público de acesso. Isso se faz por mecanismos de identificação da diferença, qualificação racial, limitação de usufruto para população moradora de rua, entre outros. Quando esse controle é exercido por agentes sociais conscientes de seus projetos, o espaço público, mesmo que hipoteticamente de livre acesso, tende a se tornar um território. Isso é ainda mais dramático quando se cria artificialmente a oposição entre formas de apropriação legítimas para o Estado, e formas ilegítimas.

Parte da literatura que aborda as novas tecnologias de controle afirma que adentramos em uma era de desterritorialização do controle social. Essa afirmação é ainda mais comum quando se trata do uso de sistemas inteligentes e vigilância na internet. 
Aborda-se a diversificação de apropriação (normatizada) do espaço público como se ela significasse o fim da formação de laços regionais. A sociedade de controle se caracterizaria pela ausência de fronteiras.

O ponto de vista proposto nessa pesquisa é distinto. Ao se entender o espaço público como o locus da disputa entre distintas formas de apropriação, percebe-se que a própria ideia de desterritorialização só pode ser aplicada a partir de cada localidade. Terá também efeito distinto em cada região, e em cada grupo social. A sociedade do controle, ao apelar à divisão dos agentes sociais, sua classificação binária (por exemplo, entre cidadãos de bem e vândalos/contraventores), e ao tentar anular a apropriação orgânica do espaço público através da modulação dos cidadãos, se torna dramaticamente territorializada, dentro de uma concepção de território baseada em Robert Sack. A utopia da assepsia do espaço se sustenta também no sonho de uma sociedade desterritorializada, universal e globalizada. Mas essa sociedade universal, ao ser normatizada por uma classe dominante previamente estabelecida, é uma sociedade ocidental, capitalista e branca: só se afirma mediante a anulação de outro tipo de apropriação.

O aspecto territorial da disputa sobre o espaço público fica tanto mais claro quanto mais dividido culturalmente (e também etnicamente) for a sociedade. Em países onde a disputa aberta pelo controle do espaço ganhou proporção física (com conflitos armados, brigas de rua, entre outros), o caráter de locus da disputa do espaço público é mais evidente. No caso da Nigéria, por exemplo, a disputa pelo espaço inclui exclusão étnica e religiosa, conforme destacou Ogoh Alubo:

O que se ilustrou é que o espaço público não é apenas um lugar para o público em geral. Como foi demonstrado, os membros do público são ainda divididos em públicos étnicos, religiosos e de gênero. Cada público parece ter uma agenda para exercer influência no espaço público ou resistir a tal influência. Na experiência nigeriana, tais lutas compensatórias resultaram em explosões de violência, especialmente entre grupos étnicos que são ainda divididos em nativos e colonos, bem como em grupos religiosos (ALUBO, 2011; p. 91).

O argumento de Ogoh Alubo é que a ideia de um espaço público para "todos os públicos" é por si só uma ilusão. Não existe a figura de "todos os públicos", uma vez que 
existem divisões étnicas, culturais, de gênero e também econômicas. Quanto mais dividida seja uma sociedade, mais dramática tende a ser a disputa nos espaços públicos. O Brasil, país que foi colônia, que aboliu a escravidão há apenas 130 anos, e que ainda possui um abismo social de grandes proporções, é um desses locais onde raramente os espaços públicos são para "todo o público".

O caráter racista da sociedade brasileira já foi exaustivamente estudado por geógrafos, historiadores, sociólogos, entre outros ${ }^{17}$. No Brasil, conforme ressaltado por Wilson do Nascimento Barbosa, existe uma relação dialética entre brancos e negros. Ao longo da história brasileira, inclusive após a abolição da escravatura, os costumes dos negros foram criminalizados. Suas vestimentas, suas festas, sua língua, foram marginalizados. Durante o processo de formação das cidades de tipo industrial, no Brasil, os negros foram expulsos de parte dos espaços urbanos. Foram tratados como o "outro" do branco. Todos os defeitos do país foram empurrados como se fossem resultado da existência dos negros. Eram eles a fonte do crime, da desordem, do atraso. Na prática, formou-se dois tipos de sociedade, uma da elite (ideologicamente identificada como branca e ocidental) e outra da massa pobre (ideologicamente identificada como negra, e bárbara). Na prática, o caráter neocolonial do Brasil levou a uma situação onde parcela da população, etnicamente e culturalmente identificável, fosse tratada como não pertencente à sociedade brasileira. Conforme lembra Wilson do Nascimento Barbosa:

\begin{abstract}
Por outro lado, a esperança de assimilação cultural do Brasil pela Europa apenas levou ao reforço da divisão étnica do país, com a aglomeração de uma cultura de cópia europeia em torno do núcleo de dominadores sociais políticos. E o empurramento, para a outra margem, do trabalho, da pobreza e da expressão afro-indígena, reforçando a separação de modos-de-vida entre os "dois brasis". Isso não pode ser negado. A rápida urbanização expressa hoje no mesmo cenário a ruptura drástica ente os dois níveis de rendimento e os dois modos-de-vida (BARBOSA, 1981; p. 11).
\end{abstract}

17 Para algumas abordagens sobre o racismo, Estado, e espaço, no Brasil, ver: GUIMARÃES, Antonio Sérgio Alfredo. Preconceito de cor e racismo no Brasil. Revista de antropologia, v. 47, n. 1, p. 9-43, 2004; CUNHA JUNIOR, Henrique. Racismo antinegro, um problema estrutural e ideológico das relações sociais brasileiras. Política Democrática: Revista de Política e Cultura. Brasília Fundação Astrogildo Pereira, ano VII, n. 21, p. 118-127, 2008; ZAMORA, Maria Helena Rodrigues Navas. Desigualdade racial, racismo e seus efeitos. Fractal: Revista de Psicologia, v. 24, n. 3, p. 563-578, 2012; DO RIO CALDEIRA, Teresa Pires. Cidade de muros: crime, segregação e cidadania em São Paulo. Editora 34, 2000; GUIMARÃES, Antonio Sérgio Alfredo. Tirando a máscara: ensaios sobre o racismo no Brasil. Paz e Terra, 2000; ADORNO, Sérgio. Discriminação racial e justiça criminal em São Paulo. Novos estudos CEBRAP, v. 43, p. 45-63, 1995. 
A existência de dois brasis etnicamente identificáveis permite entender que por trás da divisão binária entre "homens de bem" e "vândalos" está também uma divisão entre dois modos de vida. Relações culturais e formas de apropriação do espaço público foram criminalizadas no Brasil ao longo dos últimos séculos, criando um falso consenso sobre dadas leis. Como já argumentamos, os costumes são combatidos de acordo com o local onde é realizado, e também de acordo com quem realiza o costume. As cidades brasileiras, em especial as metrópoles, possuem fronteiras internas (ou muros) (DO RIO CALDEIRA, 2000), que fazem com que parte da população habitante da cidade seja tratada como um estrangeiro quando atravessa ditos muros.

Parte do sistema de controle social é utilizado como forma de garantir que parcela da população identificada como não oriunda ou não pertencente ao local seja constantemente assediada. Cria-se um clima em que parte da população não se sente confortável no espaço público em questão. Veja, que nesse contexto, a máquina do estado e instrumentos privados de controle são utilizados para que o espaço público seja destinado a um público específico. O fato de, no Brasil, conforme do Sistema Integrado de Informações Penitenciárias, 64\% dos presos se auto declaram negros, leva a parte dessa população a ter receio da atuação policial. Conforme o Atlas da Violência de 2018, 71,5\% das vítimas de ferimentos fatais causados por arma de fogo é negra ${ }^{18}$. Ainda, os negros e pardos foram, entre 2014 e 2016, 67\% das vítimas de mortes causadas por intervenção policial (NUNES, 2018). Evidentemente, nessas condições é natural que a ampliação do controle exercido pela polícia sobre o espaço público tenha efeito de criar incomodo na população negra que antes frequentava aquele espaço.

É verdade que parte do controle visa, antes de tudo, favorecer à formação de uma sociedade de mercado, onde as praças, as ruas, e qualquer espaço público possam servir à geração de valor. No entanto, a divisão do país em dois brasis também cria uma cisão entre quem pode e quem não pode gerar ou fazer circular o valor. A perseguição à parcela do comércio ambulante, por exemplo, não se trata de garantir o bom funcionamento do mercado, mas o de impedir que a renda gerada pelo comércio "vaze" para a população mais carente, tida como uma intrusa em seu próprio país.

Se, no Brasil, parte da população nativa é tratada como não pertencente à civilização brasileira (ocidental), então é provável que haja similaridades significativas

\footnotetext{
18 Negra ou parda, conforme classificação utilizada pelos autores do Atlas da Violência
} 
entre o uso das tecnologias de controle (incluindo as ferramentas do videomonitoramento, o discurso do medo, a criminalização de costumes, entre outros) no Brasil e aquele uso praticado em países que combatem supostas ondas de imigração ilegal. Nesse caso, há de se verificar o que pesquisadores que refletiram sobre tecnologia de controle e imigração descobriram em seus estudos. Meghan Mcdowell e Nancy Wonders trouxeram uma reflexão pautada no acumulo das últimas décadas de parte dos estudos sobre o tema:

\begin{abstract}
Em resposta, muitos Estados-nação ocidentais estão empregando "métodos altamente técnicos, cada vez mais punitivos e inovadores de controle de fronteiras" e estratégias de aplicação da imigração que Pickering e Weber (2006: 9) denominam "tecnologias de controle". Broeders e Engbersen (2007) argumentam que as "tecnologias de controle" implantadas na luta contra a imigração "ilegal" seguem duas lógicas. Primeiro, tecnologias de controle são usadas para localizar, deter ou deportar migrantes "ilegais" suspeitos. Em segundo lugar, as tecnologias de controle são empregadas para "excluir [em vez de localizar, deter ou deportar] imigrantes irregulares de instituições-chave da sociedade, como o mercado de trabalho e o mercado imobiliário, e até mesmo de redes informais de compatriotas e familiares". Nossa pesquisa centra-se na ascensão do estado de vigilância e dos rituais de execução como duas tecnologias de controle interligadas que promovem a identificação e exclusão de migrantes do espaço público (MCDOWELL \& WONDERS, 2009-2010; p. 55).
\end{abstract}

O que Meghan e Nancy chamaram a atenção é que estudos recentes têm apontado é que parte do sistema de imigrações dos países ocidentais tem se caracterizado pelo uso de ferramentas de controle. Esses atuam de forma a (i) levar parte dos imigrantes ilegais à exclusão física da sociedade (expulsá-los do país); e (ii) levar outra parte a continuar fisicamente na sociedade, mas excluídos da sociabilização normal. Veja que o que elas propõem é que não se trata de dois mecanismos em separados (o da identificação para exclusão física em contraponto ao da exclusão social), mas sim de mecanismos interligados, e portanto interdependentes.

Essa "novidade" nos países ocidentais é bem conhecida nos países de passado colonial. Onde a ocidentalização se deu através da destruição de laços culturais e sociais previamente existentes, o mecanismo da exclusão física somado à desarticulação social foram o ponto de partida para formação de uma sociedade de novo tipo. A diferença fundamental é que nos países coloniais, a exclusão física não era a deportação, mas sim a prisão, ou a morte. Evidentemente, as formas que se aplicaram a perseguição à parcela 
da população tratada como não pertencente da sociedade que se visava construir mudou ao longo dos anos. Na fase colonial, tendia a ser mais direta, e legalmente referenciada. A escravidão, o apartheid social, a negação do direito político, etc., podiam, à época, ser abertamente declaradas. Hoje, para que a exclusão social seja vista como legítima, ela não pode mais ser abertamente declarada. O racismo, quando aberto, se torna indefensável. Mediante a capacidade de resistência da população, ele não é mais capaz de induzir disciplina. Daí a necessidade de criar falsas associações. Criam-se eufemismos e criminaliza-se comportamento. A forma de andar, a formação de uma roda de conversa na rua, as vestimentas dos transeuntes podem servir de desculpa para classificação de "comportamento suspeito", que leve à abordagem policial, criando um clima de terror.

A hipótese de um sistema de videomonitoramento inteligente reforça a sensação que o espaço público deve ser evitado por aqueles que a sociedade vê como os "suspeitos de sempre". Especialmente quando pretendem realizar práticas culturais consideradas ilícitas. O medo da exclusão física leva a um auto-isolamento, que redunda na exclusão social, conforme Mcdowell e Wonders ressaltaram, ao analisar o comportamento de imigrantes no Arizona à luz de pesquisas recentes:

\begin{abstract}
Os imigrantes regularam sua mobilidade e modificaram suas atividades diárias para evitar o risco de detecção por tecnologias de controle dentro dos espaços urbanos no Arizona. As estratégias de acomodação empregadas pelos migrantes revelam seu poder de resistir e a opressão que eles experimentam no Arizona. Os participantes escolheram se auto-segregar nas áreas limitadas que identificaram como seguras: o lar, a igreja e as escolas de seus filhos. A auto-segregação é evidência de que as tecnologias de controle, como a vigilância e o policiamento, operam para limpar ou "purificar" o corpo político e assegurar que o espaço público (parques, bibliotecas, ruas e hospitais) seja amplamente reservado para aqueles privilegiados por cidadania, riqueza e, mais importante, brancura (Romero, 2006; Amster, 2008).(MCDOWELL \& WONDERS, 2009-2010; p. 68)
\end{abstract}

O argumento das autoras, portanto, é que as tecnologias de controle (em especial as de vigilância e policiamento) visam, também, criar uma situação que leve à população imigrante se auto segregar. Observaram que os imigrantes ilegais buscam formar laços seguros separados do restante da sociedade, e veem o trânsito nos espaços externos aos ditos laços como áreas de risco. Na prática, evitam se expor em locais vigiados, com medo que possam ser identificados e deportados. Interessante notar que, caso se substitua o termo "imigrante" pelo termo "negro" (ou "pobre"), e "Arizona" por "São Paulo", 
o trecho pode ser facilmente utilizado para discorrer sobre a segregação étnico-cultural em São Paulo.

A existência de mecanismos para identificar pichadores, para localizar comerciantes ilegais, detectar manifestantes potencialmente violentos, e alertar quanto às situações de risco, levam aos agentes sociais identificáveis como prováveis infratores a evitar os locais onde estiverem instaladas as câmeras de vigilância. Cria-se, portanto, um reforço para a assepsia do espaço público através do isolamento social dos agentes tidos como perturbadores.

Importante ressaltar que sendo os mecanismos de vigilância voltados ao estabelecimento de um clima de perseguição ao "ilegal", basta que haja a sensação que o mecanismo funciona. Isso é, hipoteticamente, ainda que o videomonitoramento inteligente não haja sido implementado, caso ele seja propagandeado como se houvesse sido, ele serve como mecanismo de pressão para expulsar parcela da população do espaço público e mantê-la à margem.

No entanto, para justificar o uso da ferramenta de controle para modelar o espaço público, é necessário que a justificativa oficial seja verossímil. Isso quer dizer que a parte da população que apoia a instalação de videomonitoramento inteligente, por exemplo, realmente tema a impunidade do crime. Mas, conforme lembra Cindi Katz, o verdadeiro drama da modelação do espaço público não é o risco que ocorra crimes que inviabilizem o uso do espaço. O drama consiste em que as respostas dadas ao crime são desproporcionais, e resultam na transmutação do espaço público:

\footnotetext{
O terror real não é o melodrama do sequestro, que, no por mais horrível, é extremamente raro; Em vez disso, é a erosão constante do meio ambiente do cotidiano e a privatização de todas as estratégias para lidar com isso. Essas estratégias agravam o problema ao longo das linhas de classe, raça e gênero de maneiras absolutamente não surpreendentes. Quando uma coisa mundana como o jogo infantil é fetichizada, o compromisso da produção social é fraco na melhor das hipóteses (KATZ, 2006; p. 116).
}

Para Cindi, a mercantilização das praças, como resposta ao medo do sequestro de crianças, nos EUA levaram à perda do papel das mesmas como espaço de sociabilização da infância. Note que a abordagem de Cindi é bastante distinta da proposta aqui. Ela 
divide o espaço público de acordo com sua função social, opondo à reprodução social saudável a mercantilização e privatização da sociabilidade. No entanto, sua conclusão é bastante clara, e de acordo com a literatura especializada: o medo do crime leva à adoção de estratégias de controle que transmutam o ambiente público, diminuindo o acesso e reduzindo seu papel na livre reprodução da sociedade.

Mesmo que se entenda que o espaço público é o lócus do conflito, e a assepsia do mesmo não anula sua função pública, apenas reduzindo o perfil do público que utiliza o espaço, a conclusão contínua similar. O medo do crime mesmo que injustificado, também está em disputa. Por um lado, o ambiente visto socialmente como degradado, ou perigoso, afasta do espaço público parte da população, em especial aquela de renda média ou alta, que etnicamente e culturalmente não se identifica com a camada mais pobre. Ainda que o risco da ocorrência de um crime violento seja pequeno (em 2014 foram registrados 19 homicídios na Sé. Em 2017, foram registrados 21 homicídios, no mesmo bairro), o discurso da existência da violência afeta o tipo de sociabilização que se constrói em cada localidade. Em oposto, ao se tratar todo crime como se fosse ligado, e não se regionalizar os tipos de crimes que ocorrem em cada bairro, trata-se todo contraventor como potencial criador de caos, e propagador da insegurança pública. Quando se constrói um discurso de vigilância total somado ao de tolerância zero, buscase retirar do espaço os contraventores visivelmente identificados. O objetivo é tirar do espaço aquele que perturba a utopia de um espaço completamente seguro. O resultado é que a convivência entre os culturalmente diferentes diminui. Daí parcela dos pesquisadores entenderem que a assepsia do espaço público diminui seu papel como espaço da reprodução (diversificada) da sociabilidade. Daí o discurso de membros do movimento negro de que, em uma sociedade racista, a vigilância se faz contra a camada mais carente e mais distinta étnica e culturalmente da elite local.

\subsection{CONTROLE E AGENTES SOCIAIS}

Até o presente momento, a relação entre o sistema de vigilância e a sociedade de controle foi tratada em abstrato. Tratou-se das tecnologias de controle, do sistema de monitoramento, da estrutura de modelação dos indivíduos. Colocou-se de um lado a massa de indivíduos, do outro o sistema social. Isso porque visava-se antes definir alguns 
dos principais conceitos que permitem entender a relação entre controle, segurança, e organização da sociedade. No entanto, na realidade as relações sociais não ocorrem de forma abstrata. Sua concretude se dá através da relação entre agentes sociais e políticos. Quando se em sistemas de vigilância e sociedade de controle, é necessário dizer que também está se discutindo as instituições e as pessoas envolvidas na formulação e aplicação da vigilância. A ressalva que se deve fazer é que nem sempre os agentes isolados possuem completo conhecimento do funcionamento das ferramentas de controle da qual eles mesmos fazem parte. Isso porque as ferramentas de controle são fruto de uma organização social. As ferramentas são construídas politicamente por uma elite que visa expandir sua influência, mas não são integralmente controladas pela mesma.

Uma das novidades da sociedade de controle é a pulverização dos agentes sociais envolvidos no controle. Atualmente, o desenvolvimento das tecnologias e da complexidade da sociedade permite que o controle social seja realizado por uma multitude de agentes não diretamente conectados entre si. Basta que os agentes se liguem (direta ou indiretamente) a formuladores de políticas públicas. Essa difusão dos agentes subordinados a um único plano apenas parcialmente coeso também é verdadeiro para o caso da segurança pública. David Garland chamou a atenção para essa inclusão de agentes privados na organização e realização de políticas públicas de segurança:

\begin{abstract}
Uma resposta importante foi retirar a reivindicação do estado de ser o principal fornecedor de segurança e tentar remodelar o controle do crime em uma base de parceria mais dispersa. Nesse arranjo, o Estado trabalha através da sociedade civil e não sobre ela, e enfatiza a prevenção pró-ativa, em vez da acusação e punição de indivíduos. A solução adaptativa desse tipo é politicamente difícil e institucionalmente radical. Eles envolvem a formação de organizações híbridas que atravessam os antigos limites públicos / privados; a ativação de ações preventivas por parte de comunidades, empresas comerciais e cidadãos; e a redefinição da missão organizacional de agências como a polícia, a liberdade condicional e as prisões. Os governos da Grã-Bretanha e da América começaram a desenvolver respostas adaptativas, a alcançar o setor privado para o apoio à parceria e a implementar uma nova infraestrutura de prevenção do crime e policiamento comunitário (GARLAND, 2002; p. 140).
\end{abstract}

Garland discutiu, no trecho, sobre as medidas que os governos da Grã-Bretanha e dos EUA implementaram nas últimas décadas. Em especial, discutiu o esforço dos dois governos em incluir entidades privadas em suas políticas pública prevenção ao crime e policiamento. Não é novidade a atuação de entidades privadas na área de segurança. No 
entanto, a formulação de políticas públicas que envolvam diretamente agentes privados não inteiramente controláveis pelo Estado tem sido entendida como uma nova forma de se fazer política. Trata-se do esforço de aumentar o enraizamento do Estado através da divisão de funções e diminuição do controle direto do mesmo. A atuação de entidades privadas na aplicação e formulação de políticas públicas, em especial na área de segurança, conforme Garland, depende de uma nova compreensão do papel da segurança. Oficialmente, trata-se da adoção da criminologia da vida cotidiana. Em vez de se investigar o crime ocorrido, visa-se intervir no funcionamento da sociedade, com o intuito de impedir a ocorrência do crime.

Como a polícia tem pouca capacidade de vigiar e controlar todas as ruas das cidades, pode formar parcerias com empresas de segurança privada, por exemplo. Essas deixam de ter apenas o papel de defender o patrimônio daqueles que a contratam, e passam a servir como uma espécie de agente comunitária. Suas câmeras de segurança voltadas para rua, e seus agentes armados, também serviriam para desincentivar a ação de criminosos na redondeza. Para que isso seja possível, é necessário certa integração entre a vigilância privada e o monitoramento policial. Veja que os agentes privados podem tomar atitudes que a polícia só o poder mediante mandato (ou provocação), como, por exemplo, expulsar pedintes ou "pessoas suspeitas" da calçada dos estabelecimentos particulares.

A atuação conjunta de agentes privados ao lado das secretarias de segurança favorece à utopia de assepsia do espaço. A parceria entre seguranças privados e polícia ${ }^{19}$ gera, no cidadão, a impressão que a segurança privada é portadora de autoridade. Quando isso ocorre, as empresas privadas tornam-se, também, agentes sociais da política pública que visa exercer o controle sobre o espaço, expulsando dele qualquer perturbação da apropriação normatizada do cotidiano. Não é à toa que o empresariado paulista colaborou com o Detecta, assim como, em 2017 e 2018, colaborou também com o City Câmera (projeto da prefeitura de São Paulo).

Essa relação entre entidades privadas e o Estado não é feita de forma neutra. Trata-se da reafirmação do Estado como promotor de um tipo de sociedade voltada ao mercado. Evidentemente, a aliança entre público e privado só é feita se for de interesse

19 Parte das agências de segurança particular emprega policias e ex-policiais. Na prática, a colaboração da polícia com empresas de segurança é também a colaboração do policial em serviço com um que não está em serviço. 
de uma camada social que detêm o poder tanto no Estado como nas entidades privadas com qual se forjam as alianças. A relação entre o Estado e agentes privados já foi vastamente estudada. $\mathrm{Na}$ verdade, parte considerável dos estudos sobre o espaço público visa demonstrar como o Estado tem atuado em favor do mercado. Mas o que buscamos chamar a atenção é que ao beneficiar o mercado, o Estado também beneficia a formação de uma sociedade de controle, que no que toca ao espaço público, caminha em direção à utopia da assepsia. Um trecho de Mark Kelly permite entender como se dá essa relação entre mercado e assepsia do espaço:

\begin{abstract}
A governança neoliberal envolve especificamente o estado orientando-se principalmente para promover os mercados. O neoliberalismo viu os governos quebrando agressivamente as solidariedades dos trabalhadores que são julgados para interferir no funcionamento dos mecanismos de mercado, bem como a privatização desenfreada (mas paradoxalmente patrocinada pelo Estado). É assim (uma coisa) responsável pela crescente individualização e comercialização observada por Deleuze em seu "Postscript". Tais intervenções ameaçam recriar as condições de trabalho anteriores ao século XX no Ocidente ao romper as próprias solidariedades que produziram segurança para os trabalhadores no século $\mathrm{XX}$, porque essa segurança é vista como uma distorção das condições ideais do mercado. O neoliberalismo é, portanto, uma combinação de novos e antigos, como o próprio nome sugere, ressuscitando as condições clássicas em uma situação nova. Isso não implica, no entanto, uma nova tecnologia de poder - em vez disso, implica uma nova relação do estado com a economia dentro do capitalismo disciplinar e biopolítico (KELLY, 2015; p. 162).
\end{abstract}

Mark Kelly, ao argumentar que Deleuze interpretou errado as novas formas de exercício do poder, ressaltou justamente alguns aspectos essenciais da relação da teoria de Deleuze com a de Foucault. Observou que ambos discutiram um aspecto do capitalismo, que é a forma pela qual se cria os mecanismos de reprodução das hierarquias de poder. Para Kelly, as novas ferramentas indicadas por Deleuze nada mais são do que uma pequena mudança que não alterou essencialmente as relações de poder. No entanto, reconhece que as relações sociais desenvolvidas a partir do neoliberalismo tem como um de seus aspectos o fortalecimento da individualização e mercantilização das relações pessoais. A relação anterior de construção de disciplina se dava pela massificação. Agora, se dá pela individualização. Note que a afirmação de Kelly apenas absorveu o discurso de Deleuze pela metade. Para Deleuze, se trata de (a) personalização não individualizada (através do estabelecimento de perfis aproximados), ao mesmo tempo que se transforma as massas em (b) conjunto amostral. 
Seja como for, de fato uma das características é a dissolução de laços de solidariedade e de espírito de corpo. A delegação e privatização das relações, construindo agentes sociais com função de tipo pública, mas que não estão submetidos diretamente ao poder estatal, se dá, no neoliberalismo, de acordo com o objetivo de maximização de lucros e diminuição de gastos. Todavia, ressuscita um tipo de relação social inspirada no século XIX: a reorganização das relações sociais sob a promessa de progresso. A tese que o crime pode ser prevenido mediante a identificação prévia de situações de risco (realizada por agentes públicos e privados), e se estabelecendo uma sociabilização normatizada e controlada, acaba expulsando as relações sociais espontâneas em favor das relações previamente regradas. Em nossa sociedade, isso significa favorecer um tipo de relação que é mercadológica e elitista. Em uma sociedade de passado escravista, o significado dessa assepsia e mercantilização do espaço é a criminalização de determinadas relações culturais que não sejam tipicamente oriundas da cultura ocidental branca $^{20}$.

Evidentemente, o higienismo de antigo tipo se distingue da assepsia do espaço moderno. Uma das diferenças é que no passado o racismo era explícito. Outra diferença é que no século XIX e no início do século $X X$, a burocracia estatal era o principal mecanismo de gestão da política. Atualmente, a política se faz através de uma diversidade de instrumentos, conforme Michael Hardt e Antonio Negri ressaltam:

\begin{abstract}
Um primeiro princípio que define a administração imperial é que nela a gestão dos fins políticos tende a ser separada da gestão dos meios burocráticos. $O$ novo paradigma não é, portanto, apenas diferente do oposto do antigo modelo de administração pública do estado moderno, que continuamente se esforçou para coordenar seu sistema de meios burocráticos com seus fins políticos. No regime imperial, as burocracias (e os meios administrativos em geral) são considerados não de acordo com a lógica linear de sua funcionalidade com os objetivos, mas de acordo com as lógicas instrumentais diferenciais e múltiplas. O problema da administração não é um problema de unidade, mas de multifuncionalidade instrumental. Considerando que, para a legitimação e administração do Estado moderno, a universalidade e a igualdade das ações administrativas foram primordiais, no que diz respeito ao regime imperial, o que é fundamental é a singularidade e a adequação das ações aos fins específicos (HARDT \& NEGRI, 2000; p. 340).
\end{abstract}

20 A relação entre a polícia e a cultura hip hop é bastante contraditória. Ao passo que muitas atividades de hip hop são oficialmente reconhecidas e até protegidas pela polícia, a manifestação espontânea do hip hop muitas vezes é alvo de abordagem policial. No ABC paulista, a situação é ainda mais dramática. Lá, mesmo batalhas de rap programadas previamente são, por vezes, interrompidas pela polícia. Ver: https://www.vice.com/pt_br/article/xyqmdz/batalha-da-matrix-sao-bernardo-sao-paulo-repressao-policial; e e http://revistavirus.com.br/a-repressao-as-batalhas-de-rap-o-caso-do-abc-paulista/. 
Na obra "Império", ressaltam que uma das novidades do novo período histórico é a cisão entre a gestão da política e as burocracias estatais. Segundo os autores, o novo tipo de imperialismo se caracteriza pela ausência de uma única potência política que domine diretamente sobre as colônias. Ainda, entendem que, no interior dos Estados, a política é gerida por órgãos públicos e privados, sem distinção. Isso faz com que os objetivos políticos das classes dominantes, dos monopólios internacionais, não precisem sequer ser declarados devido a fluidez da estrutura de poder. Ao menos em parte, as doutrinas eticamente questionáveis podem ser aplicadas sem grandes dificuldades pelo caráter interno do interesse privado dentro das estruturas e instituições públicas. Um exemplo típico da consequência de uso de instituições privadas em políticas de segurança é o da Blackwater, empresa de seguranças contratadas pelo governo dos EUA para atuar no oriente médio (Iraque e Afeganistão). Lá, a Blackwater foi acusada de realizar torturas sistemáticas contra população detida por seus agentes, tendo sido acusada de realizar genocídio em 2009. Apesar de ter sido expulsa do Iraque em 2010, Erik Prince, fundador da Blackwater foi conselheiro informal de Trump durante a transição presidencial (The New York Times: "Adviser to Emirates With Ties to Trump Aides Is Cooperating With Special Counsel”, 06/03/2018)

Note que, conforme Hardt e Negri, atualmente existe a tendência da adequação das ações, dos instrumentos e dos fins. Ou seja, para cada política que se formula para sociedade, tanto as ferramentas quanto os próprios agentes encarregados são modelados a fim de garantir sua implementação. Uma mesma política pode ser subdividida em seções, sendo cada seção implementada por um agente diferente, que pode ter ou não consciência do projeto político que implementa.

Para análise do Detecta, isso significa entender que sua eficiência depende de três seções diferentes. A primeira é a ação direta da polícia, caracterizada pelo uso do videomonitoramento inteligente no policiamento. A segunda é a integração entre a vigilância privada e a polícia, em especial através da colaboração entre as empresas de segurança que analisam e fazem triagem de imagens envolvendo ocorrências nos arredores dos prédios protegidos pelos sistemas contratados por clientes. Veja que nessas duas seções o que diferencia o Detecta do sistema de videomonitoramento 
comum é, na verdade, o uso de um banco de dados integrados, e não é o uso do software de monitoramento inteligente. A terceira seção, fundamental para que se cumpra a função de prevenção ao crime (uma vez que ambas anteriores são mais eficazes como ferramenta de investigação pós-facto), é a da publicização do programa. Essa publicização foi realizada através dos jornais, que são agentes sociais que não fazem parte do sistema de segurança. A atuação dos jornais na publicização do Detecta se deu no sentido de, em primeiro momento, divulgar qualquer alegação da Secretaria de Segurança do Estado de São Paulo quanto ao sucesso do Detecta. Só a partir da demora de entrega do sistema de monitoramento inteligente é que alguns jornalistas passaram a questionar o programa. Veja que, no que toca a grande mídia, o Detecta foi questionado quanto a sua eficiência, mas não quanto a sua natureza. Ou seja, passou-se a duvidar da capacidade do programa de realmente aumentar a segurança nas ruas de São Paulo, mas não se discutiu que tipo de segurança iria se implantar em primeiro lugar.

É importante ressaltar que, a partir do momento que há uma multiplicação do número de instrumentos e agentes na implementação da política, há redução da capacidade de harmonia entre os agentes envolvidos. O custo da diluição da política entre agentes aparentemente não coordenados é justamente a diminuição da capacidade de coordenação. Ou seja, quando as políticas pretendidas encontram dificuldade de implementação, tende a ocorrer diminuição na capacidade de construção de consenso. Parte dos agentes podem se distanciar do projeto que aparenta não poder ser tranquilamente implementado. Nessas condições, o programa político pode ter que passar por mudanças. Projetos podem ser abandonados em favor de outros. Essa nova forma de fazer política não é nem exclusivamente discutida pela academia, e nem é tão nova quanto parece. Já na Guerra Fria, os sistemas de inteligência dos EUA discutiam a importância da organização da política para além da burocracia estatal. Na época, chamava-se o esforço de influenciar a sociedade de Guerra Psicológica. Nosso argumento é que, diante as características do Detecta, ele não foi realmente um programa factível de segurança pública, mas sim uma peça de Guerra Psicológica, implementada durante um período de acirramento das disputas políticas sobre o espaço. 


\section{ASPECTOS DAS OPERAÇÕES PSICOLÓGICAS E GUERRA TOTAL NA DISPUTA PELO ESPAÇO PÚBLICO}

Até o momento, definimos o espaço público como locus do conflito. Ainda, apontamos a existência da oposição entre duas utopias distintas: a de assepsia do espaço, onde toda apropriação do espaço público deve ocorrer dentro do previamente normatizado, e a política se faz fora do espaço público, e o conflito no espaço público anulado; e a utopia da livre apropriação política do espaço, onde a apropriação do espaço ocorre organicamente, e todo conflito ocorrido no espaço deve ser resolvido politicamente em cada caso em que ocorra ${ }^{21}$. Buscamos apontar que, nessa disputa pelo espaço público urbano, o mesmo pode se transformar em um território em qual o Estado, através de suas forças de segurança, junto a parte da sociedade civil, busca excluir camadas da população do uso do espaço. Uma das facetas dessa territorialização do espaço urbano é a adoção da arquitetura de guerra, descrita por Graham (GRAHAM, 2011).

Abordamos uma leitura do atual estágio dos mecanismos de reprodução da estrutura social, dando ênfase à teoria da existência de uma sociedade do controle, onde a disciplinarização da massa não é mais o objetivo principal das ferramentas de poder. Essa teria sido abandonada em favor do esforço para a modelação dos comportamentos cotidianos dos distintos grupos sociais, incluindo os grupos até então considerados resistentes à disciplina. Não existe oposição direta entre a sociedade de controle e agrupamentos favoráveis à ampliação do debate político. Na verdade, a reprodução dos mecanismos de poder na sociedade de controle depende, em grande medida, da multiplicação do debate, ao ponto de impedir que qualquer grupo isolado se torne verdadeiramente disruptor. Assim, não pode haver associação direta entre sociedade de controle e assepsia do espaço. Nesse contexto, parte da transformação do espaço público em território depende também de uma disputa pelo subjetivo da população.

A divisão da sociedade em agrupamentos ligados às utopias opostas, em alguma

21 Reforçamos mais uma vez que não se trata de opor a “segurança pública” contra a “a anarquia”, ou a "fascistização/ mercantilização do espaço” à “apropriação política”. As utopias referidas dizem respeito ao locus da política: se o espaço público deve ou não ser local de disputa política e cultural. Se o for, então não existe espaço para criminalização de costumes. Se não o for, então as regras politicamente formuladas desde fora precisam ser garantidas. 
medida, leva a formação de disputa pelo poder. Evidentemente, as tecnologias de poder são utilizadas tanto pelos que estão no poder quanto por aqueles que o contestam. $O$ que se deseja entender é como o Detecta foi utilizado como uma ferramenta de controle que não se limitou à sua aplicação técnica na disputa pelo espaço público. Não basta compreender que na sociedade de controle (que é uma abstração teórica) a disputa pelo subjetivo faz parte das tecnologias de poder existentes. Enquanto discutia-se a sociedade em geral, o conceito de sociedade de controle bastava. No entanto, para se debruçar sobre os interesses de um dos lados da disputa (mais especificadamente do subgrupo alocado na Secretaria de Segurança do Estado de São Paulo), é necessário buscar na literatura indícios que de fato as políticas de segurança conscientemente buscam disputar o subjetivo, mesmo de camadas da população que não lhe são hostis.

Esse é um debate que foi mais abertamente realizado pelos formuladores e teóricos das políticas de segurança nacional e de políticas de guerra, em especial dos EUA. O exército americano possui longa tradição de formular sobre a disputa política desde um ponto de vista de sua afirmação geopolítica, ligada à constituição de sua hegemonia cultural. Documentos internos e textos públicos foram usados para delimitar e formular políticas de segurança daquele país. Essas, por sua vez, influenciaram a formulação de políticas de segurança em outros locais, como no Brasil 22 .

A disputa pela subjetividade como parte de programas militares ou de segurança nacional dos EUA passou por diferentes nomes. Foi "programa doutrinário", "guerra psicológica”, "guerra política”, "guerra de quarta geração”, e "guerra híbrida”, ou "irrestrita”. Evidentemente, a mudança de nomenclatura também significou modificações no entendimento do papel das mesmas. A atual concepção de guerra híbrida é bastante mais complexa do que as formulações anteriores. Mas, a essência do significado da disputa mentalidade e concepções de mundo já estava delimitada desde, ao menos, 1953, como se vê em um documento interno do exército estadunidense:

22 Para uma história das parcerias entre a polícia brasileira e os EUA, ver: HUGGINS, Martha K. Polícia e política: relações Estados Unidos, América Latina. Cortez, 1998. Para algumas parcerias recentes entre a polícia brasileira os estados unidos, ver: http://fenapef.org.br/22587/; http://www1.folha.uol.com.br/fsp/mais/fs23089804.htm; https://apublica.org/2014/06/eua-treinaram-policiais-paraconter-manifestacoes-na-copa/; $\quad$ http://www.policia.sp.gov.br/noticia/lefotos.aspx?id=7335; https://www.acheiusa.com/Noticia/policiais-brasileiros-fazem-intercambio-nos-estados-unidos-12579/. Ainda, o próprio Detecta é fruto de uma parceria entre uma empresa americana e a polícia brasileira, usando como base a experiência americana de segurança pública: https://news.microsoft.com/pt-br/parceria-entre-governode-sp-e-microsoft-amplia-acoes-de-inteligencia-policial/. 
Em suas atividades de curto alcance, o programa doutrinário (como definido no Anexo $A$ ) buscará alcançar os seguintes resultados:

(1) criar confusão, dúvidas e perda de confiança nos padrões de pensamento aceitos dos comunistas convencidos, carreiristas cativos, incluindo os grupos militar e administrativo, e pessoas sob influência comunista.

(2) para preparar o caminho para múltiplos desvios e cismas nos padrões de pensamento totalitário, estimulando a curiosidade intelectual e livre pensamento em assuntos políticos, científicos e econômicos.

(3) enfraquecer objetivamente o apelo intelectual do neutralismo e predispor seus aderentes ao espírito do Ocidente. (CIA-RDP80R01731R003200050006-0; p. 1 e 2)

O documento da CIA traz alguns dos objetivos do chamado programa doutrinário. Tratava-se de um programa voltado para o combate ao comunismo. Na época, conforme indica o documento, os Estados Unidos acreditavam que estavam perdendo a batalha pelo apoio internacional ao modo de vida ocidental. Como resposta, a CIA defendia a necessidade de estabelecer um programa que visasse minar as bases de apoio ao pensamento de tipo comunista. Note que o documento colocava que era necessário gerar perda de confiança dentre os adeptos ao comunismo, e mesmo enfraquecer o apelo intelectual ao neutralismo (que era a postura de não alinhamento nem aos soviéticos, nem aos americanos).

Apesar da ênfase na luta ao comunismo, o documento também aponta outro aspecto da disputa ideológica: a afirmação do modo de vida ocidental. Para os agentes da CIA encarregados da formulação do programa doutrinário dos EUA, havia ligação direta entre a cultura ocidental e a resistência ao pensamento socialista. Por isso, conforme se vê em um trecho mais adiante do documento, é afirmado:

(c) A produção doutrinal não se limita a análises filosóficas políticas. Todos os campos de interesses intelectuais e culturais, desde a antropologia e as criações artísticas à sociologia e à metodologia científica, entram na gama do programa doutrinário.

(d) O programa doutrinário americano não se limita aos materiais americanos. Produção e atividade estrangeiras, consistentes com nossos objetivos doutrinários, serão fomentadas, promovidas e distribuídas. A aceitação à filosofia de vida ocidental, e não a apenas às ideias americanas, será um critério de seleção de materiais não americanos. (CIA-RDP80R01731R003200050006-0; p. 6)

Para combater a União Soviética, na época, os EUA se dispuseram a financiar produção intelectual em diversos campos de conhecimento, tendo como único critério a 
adoção da "filosofia de vida ocidental". Aqui está o coração da disputa pelo subjetivo das populações, tendo como objetivo a construção da influência política: a identidade entre um tipo de cultura, a ocidental, e o alinhamento político pretendido. Evidentemente, o documento trata de uma disputa geopolítica durante a guerra fria, cenário bastante distinto da disputa pelo espaço público na cidade de São Paulo. No entanto, ao longo desse capítulo, buscaremos demonstrar como as políticas de segurança conscientemente disputam o apoio da população para a aplicação de seus objetivos. Assim, buscaremos entender a importância de se estudar políticas de segurança pública também pelo impacto que teve nas percepções da população na época da apresentação do projeto, implementação, e, quando for o caso, na consolidação ou derrocada do mesmo. Para isso, serão ressaltados alguns aspectos da chamada "guerra psicológica" e da "guerra de quarta geração", que são coisas distintas, mas que tem em comum a importância dada à disputa cultural ressaltada no programa doutrinário dos EUA, de 1953.

Embora a disputa pelo espaço urbano não seja uma guerra formal, e muito menos tradicional, o uso do termo "guerra civil" vem sido utilizado para retratar o problema da violência e do caos urbano no Brasil (SOUZA, 2008; 19 a 50). Ainda, na era contemporânea, as guerras não precisam ser formalmente declaradas para que ocorram e seja internacionalmente reconhecidas como tal (os EUA jamais declararam guerra ao Vietnã do Norte, por exemplo). Nesse contexto, pode-se dizer que existem guerras civis veladas no interior de cidades onde há alto índice de violência, atuação ostensiva da polícia, e disputa pela arquitetura do espaço urbano. A existência de forças políticas que desejam transformar o espaço público em território, onde reine a utopia da assepsia, pode ser o suficiente para que se analise as disputas pelo espaço urbano como guerras. Em especial, devido ao esforço que as forças políticas realizam para angariar apoio político e descreditar seus adversários, o que é parte do objetivo das operações psicológicas.

\subsection{DEFINIÇÃO E OBJETIVO DA GUERRA PSICOLÓGICA}

Para entendermos o atual conceito de guerra de quarta geração e guerra híbrida, antes é necessário compreender o conceito de guerra psicológica. A atual forma de se pensar segurança nacional e geopolítica deve em muito à formulação sobre operações psicológicas realizadas nas últimas décadas. Ainda, buscaremos demonstrar que muito 
daquela formulação pode ser aplicada à segurança pública, facilitando a compreensão que parte dos formuladores das políticas de segurança têm sobre os criminosos, em especial quando os formuladores são adeptos da teoria criminalística da vida cotidiana.

Alfred H. Paddock Jr. possui uma definição de Operações Psicológicas que é bastante elucidativa, na medida em que ajuda a entender tanto o objetivo de uma operação psicológica como em quais campos ela pode vir a operar. Em seu texto, "Military Psychological Operations", assim diz Paddock:

Operações Psicológicas (PSYOP) podem ser definidas amplamente como o uso planejado de comunicações para influenciar atitudes e comportamentos. Consiste em ações políticas, militares e ideológicas conduzidas para criar, em grupos-alvo, comportamentos, emoções e atitudes que apoiam a consecução de objetivos. Se usado corretamente, o PSYOP normalmente precederá, acompanhará e seguirá todas as aplicações de força. Isso será realizado sob a égide mais ampla da política nacional dos EUA, e o componente militar do esforço geral de operações psicológicas deve ser coordenado de maneira completa e cuidadosa com outras agências do governo.

Mais especificamente, o PSYOP pode ser usado para desmoralizar, desorientar e confundir grupos hostis. Quando grupos hostis são alvos, o PSYOP é empregado como uma arma ofensiva que pode melhorar a eficácia global das operações militares. Também pode ser usado para unir, informar e reforçar a moral dos grupos não-hostis. Ao segmentar grupos neutros ou amigos, ele é usado para apoiar objetivos militares, desenvolvendo atitudes e comportamentos cooperativos no grupo-alvo (PADDOCK JR., 1989; p. 45).

Uma das preocupações de Paddock era quanto ao risco das operações psicológicas serem tratadas como uma espécie de instrumento militar secundário, que poderia ser aplicado ou não em determinadas situações específicas. O autor chamou a atenção para o fato das operações psicológicas serem, na verdade, o uso planejado de comunicação com objetivo de manipulação da população. O uso de instrumentos de comunicação podia ser colocado em função dos objetivos nacionais (e militares), de forma a facilitar os objetivos estabelecidos. Paddock ainda chamou a atenção para importância de se identificar quem é o alvo da operação psicológica: se são inimigos, aliados, ou parcelas neutras (não hostis) da população.

Portanto, para ele, operação psicológica é toda operação que visa informar ou influenciar o comportamento de camadas da população, sejam elas hostis ou não. Evidentemente, essa definição não se restringe ao campo de batalha. Na verdade, ela 
pressupõe que parte do público-alvo das operações psicológicas seja a população do próprio país, ainda que a lei americana proíba oficialmente o uso de operações especiais em território nacional (salvo em situações de catástrofe natural e em casos de terrorismo). Campanhas para aumentar o apoio da população a uma guerra, ou mesmo para apoiar uma reforma política ou social tida como fundamental para garantir os objetivos nacionais, também fazem parte das operações psicológicas. Um exemplo de uso de guerra psicológica fora do contexto de guerra é o combate á imigrantes nos EUA, que ganhou ainda maior repercussão desde o início do governo Trump. Uma das técnicas utilizadas, entre 2016 e 2017, foi a de acusar, sem qualquer base, jovens imigrantes de pertencerem a gangues, em especial no caso da gangue MS-13. A polícia americana prendeu 239 pessoas sob acusação de pertencerem à referida gangue. Durante o processo eleitoral, Donald Trump citou homicídios realizados pela MS-13 para justificar sua defesa de programas de combate aos imigrantes. A perseguição coridiana contra imegrantes, e acusação de que os jovens latino-americanos são pertencentes a gangues levou a população a evitar o uso de roupas que sejam normalmente identificadas com uniformes de gangue (Al Jazeer: “Trump's War on Gangs”, 11/04/2018).

Parte da política de comunicação das secretarias de segurança possui o mesmo objetivo que o definido por Paddock Jr.: "influenciar atitudes e comportamentos. Consiste em ações políticas, militares e ideológicas conduzidas para criar, em grupos-alvo, comportamentos, emoções e atitudes que apoiam a consecução de objetivos". Daí a possibilidade de se entender que a propaganda feita por órgãos públicos que desejam combater um grupo social específico (pichadores, manifestantes, pedintes, ambulantes ou outros) é também uma operação psicológica. A divulgação do sucesso no uso do videomonitoramento, por exemplo, pode ter como intuito de amedrontar pessoas que transgridem a lei, ao passo que angaria o apoio para novos investimentos no setor.

No mesmo texto, Paddock Jr. também ressaltou que as operações psicológicas não se resumem à propaganda (ao produto final). É, também, toda estrutura montada para garantir que as ações políticas possam ser realizadas e formuladas levando em consideração o ambiente emocional dos alvos:

Essencialmente, uma unidade de operações psicológicas militares envolve duas amplas categorias de atividade: pesquisa e análise, e operações. A primeira 
atividade consiste em monitorar e avaliar continuamente o ambiente psicológico em nações estrangeiras específicas para determinar como o ambiente afeta a formulação e a execução de políticas e ações dos EUA. Esta pesquisa e análise resulta na publicação de estudos e avaliações únicas. Esses estudos e avaliações fornecem a base para o estabelecimento de objetivos psicológicos para apoiar as metas dos EUA relacionadas a nações ou grupos estrangeiros. A pesquisa e a análise são, portanto, essenciais para a realização da segunda categoria ampla de atividades, a saber, o planejamento e a execução de campanhas específicas de operações psicológicas, que empregam meios de comunicação e outras técnicas para fazer com que grupos e indivíduos estrangeiros selecionados se comportem de maneira a apoiar os objetivos nacionais e militares dos EUA (PADDOCK JR., 1989; p. 54 e 55).

O autor do referido texto buscou deixar claro que as operações psicológicas, portanto, possuem duas fases: de preparação (constante) e de execução (de duração delimitada). É uma concepção errada acreditar que as operações psicológicas apenas são aplicadas após a delimitação dos objetivos pretendidos. Elas também servem para fornecer a análise que é utilizada para formular objetivos específicos (dentro de objetivos gerais). Nesse sentido, as operações psicológicas ocorrem antes, durante, e depois das operações específicas de quais elas fazem parte. Daí a importância de entender os alvos e objetivos gerais de qual fazem parte das operações psicológicas que se analisa. Embora o trecho aborde as operações psicológicas em solo estrangeiro, o método apresentado pelo autor poderia ser facilmente aplicado no contexto de disputa pelo espaço público. Ainda mais se aceitarmos como verdadeira a tese de Graham que nos países do Sul Global (o que inclui o Brasil), é comum a adoção de políticas de eliminação de redesenho das cidades por parte das elites que as governam, afim de satisfazer as necessidades do neoliberalismo (GRAHAM, 2011; p. 84)

Se tomarmos como verdade a afirmação de David Garland que as mídias de massa têm favorecido o discurso emocional em detrimento do técnico, então deve-se aceitar que as equipes de pesquisa e análise do ambiente emocional são fundamentais também para formulação de políticas públicas. Se as propagandas realizadas pelas instituições de segurança também podem ser compreendidas como operações psicológicas, a preparação das mesmas também faz parte das ditas operações. As políticas públicas, quando formuladas como resposta a anseios emocionais, visam antes impactar na opinião pública, e através dessa atingir resultados desejados. Hipoteticamente, uma política pública pode ser formulada e aplicada visando única e exclusivamente angariar apoio para a instituição (ou gestão) que a aplica. No caso, tratar- 
se-ia de uma operação psicológica voltada à população aliada ou não hostil. Ainda, pode ser realizada como propaganda visando desestimular comportamentos considerados hostis. Assim, uma política de segurança pode ser formulada com base em uma tecnologia ainda de difícil implementação (como o videomonitoramento inteligente) apenas para criar a sensação que a polícia em breve se tornará capaz de eliminar toda sorte de comportamento criminoso.

Parte das operações psicológicas são pensadas como alternativa a uma atuação belicosa. Considera-se que a propaganda como ferramenta de indução a um comportamento desejado é mais barata e menos arriscada do que intervenção belicosa, com uso de tropas convencionais. Christopher Simpson chamou a atenção para esse aspecto:

\begin{abstract}
Persuasão e propaganda eficazes eram (e são) amplamente vistas como uma alternativa relativamente racional à brutalidade extraordinária e despesa da guerra convencional. A comunicação de massa persuasiva pode melhorar as operações militares sem aumentar as baixas, argumentam seus defensores, especialmente ao encorajar um inimigo encurralado a se render em vez de lutar até a morte. Da mesma forma, apoiando a moral e melhorando o comando e controle de suas próprias forças, aqueles que podem explorar essas técnicas obtêm claras vantagens militares. Mais fundamentalmente, as agências de segurança dos EUA veem propaganda e guerra psicológica como um meio de ampliar a influência do governo dos EUA muito além dos territórios que podem ser controlados diretamente pelos soldados dos EUA, e a um custo relativamente modesto. A transmissão de rádio da CIA para a Europa Oriental, por exemplo, tornou-se "uma das ferramentas mais baratas, seguras e eficazes da política externa [dos EUA]", como argumentou Jeane Kirkpatrick - há muito uma defensora ativa das operações psicológicas dos EUA. (SIMPSON, 2015; p. 6 e 7)"
\end{abstract}

Christopher Simpson destacou que os defensores das operações psicológicas veem as mesmas como (a) uma alternativa menos custosa; e (b) como uma possibilidade de ampliar a área de influência para locais onde, de outra forma, não seria capaz. A propaganda pode ser entendida como uma ferramenta para conquistar aliados e desestimular adversários, buscando dessa forma influenciar os rumos de sociedades que, não fosse pelos efeitos da propaganda, poderiam vir a tomar rumos que atrapalhassem os objetivos de quem implementa a propaganda.

Essa mesma compreensão pode ser aplicada ao uso da guerra psicológica na segurança pública e mesmo na disputa pelo espaço público. Um exemplo desse tipo de 
uso é a chamada "War on Graffiti" (Guerra a pichação) em Nova lorque. Os mais de 20 anos de operações psicológicas para fim de controle do espaço novaiorquino levou a processos de higienização urbana. O policiamento direto é custoso, depende da disponibilidade de pessoal, e, quando há resistência, pode resultar em conflito. O conflito, por sua vez, pode resultar no desgaste da imagem da polícia, resultando em perda de credibilidade, fato que diminui a percepção de segurança. Já a propaganda como parte de uma operação psicológica permite à polícia parecer mais capaz de prevenir crimes do que realmente é, desanimando a atuação de agentes contraventores e aumentando a sensação de segurança. Dessa forma, pode conseguir adquirir influência sobre o espaço público (impondo regras comportamentais que não necessariamente representam a cultura orgânica da população) onde de outra forma não teria.

A possibilidade de estender a influência além da capacidade real de garantia de domínio efetivo se dá porque a política não é apenas um dos campos de combate. É, na verdade, o objetivo e instrumento organizador. Dessa forma, o combate físico e a propaganda são apenas ferramentas para se atingir o objetivo político, como ressaltou Angelo M. Codevilla:

\begin{abstract}
Nada é mais enganoso do que a noção de que a política é um aspecto do conflito entre outros - militar, econômico, etc. Na verdade, a política não é uma parte do conflito, mas o princípio organizador do todo, é o que faz sentido em uma luta, se de fato houver algum sentido. (...) Quaisquer medidas militares ou econômicas tomadas de acordo com essa decisão que não sejam razoavelmente calculadas para trazer a vitória são sinais de incompetência política ou de um desejo de morte. Em outras palavras, as ferramentas da guerra política são apenas partes do que deve ser um plano essencialmente político, orientado para o sucesso, que também envolve tudo o que o governo está fazendo (CODEVILLA, 1989; p. 78 e 79).
\end{abstract}

Angelo M. Codevilla, em seu artigo "Political Warfare" buscou ressaltar que a guerra política não se resume aos instrumentos normalmente classificados sob o rótulo pouco claro de "guerra política" (incluindo guerra psicológica). Na verdade, toda guerra é política, pois ela visa atingir objetivos políticos. Quem promove a guerra deve a pensar como parte de um plano político maior, que envolve todas as demais ações do Estado. Caso não o seja feito, a guerra se torna um custo, sem sucesso garantido, e que pode botar em risco a própria credibilidade do Estado. Assim, para Codevilla, não é que a 
propaganda é um instrumento de guerra, mas sim que a guerra é um instrumento do Estado para atingir seus objetivos políticos, ao lado da propaganda e todos demais instrumentos disponíveis.

Quando pensamos as políticas de segurança pública também como esforço de disputa de influência sobre o espaço público, o trecho de Codevilla apresenta uma contribuição. A propaganda como instrumento de ampliação de influência dos órgãos de segurança faz sentido apenas como parte de uma política mais ampla do Estado (ou do formulador por trás da política implementada). Assim, as intenções por trás da política proposta são elemento fundamental para se entender a mesma. Em tese, o videomonitoramento inteligente visa ampliar a segurança da população, ao diminuir a ação de criminosos. No entanto, em um Estado onde o sistema policial combate não apenas criminosos, mas também costumes e manifestações políticas e culturais consideradas disruptoras, o próprio videomonitoramento se torna uma parte da guerra política. Não é à toa que foram os próprios agentes do estado que afirmaram que o videomonitoramento pode ser utilizado para repressão de uma passeata, ou para identificar ação de pichadores, como veremos mais adiante.

No contexto da presente pesquisa, pode-se afirmar que as operações psicológicas estão subordinadas a uma guerra política pelo espaço público urbano. Existe uma (a) uma força política que enxerga o espaço público como seu território (forças de segurança do Estado de São Paulo); e que (b) busca limitar o acesso e a forma de apropriação do referido espaço, criando uma arquitetura de guerra na cidade (exclusão da população negra, de militância política, e de movimentos culturais contestadores e ressignificadores). Essa disputa se dá no quadro de uma (c) guerra política (uma guerra civil velada pelo espaço público), que tem como uma de suas ferramentas (d) a guerra psicológica, como instrumento de (e) modelação e controle dos comportamentos de camadas da população, tanto das camadas adversárias como das camadas consideradas aliadas para o projeto da referida força.

\subsection{FERRAMENTAS E ALVOS DA GUERRA PSICOLÓGICA}

As chamadas operações psicológicas, portanto, fazem parte daquilo que é mais 
amplamente denominado "guerra política". Essa, por sua vez, é a adoção de uma estratégia de posicionamento que visa ampliar a esfera de influência de um Estado, ou de um dado grupo político, para além de sua capacidade de coerção. Trata-se do uso de instrumentos de propaganda, formação de alianças, e proposição de políticas com segundas intenções. Toda vez que um grupo político faz uma movimentação com o intuito de ampliar sua capacidade de influência, ou para diminuir a influência de um grupo rival, ele está adotando uma estratégia de guerra política. Angelo M. Codevilla buscou fornecer uma definição funcional de política para o conceito de guerra política:

A política é o recrutamento de seres para apoiar ou opor causas. A guerra política é o uso de apoio humano, ou oposição, a fim de alcançar a vitória na guerra ou em conflitos não sangrentos tão sérios quanto a guerra (CODEVILLA, 1989; p. 77).

Veja que Codevilla não está interessado em uma definição filosófica ou sociológica de política. A visão que apresenta é uma visão funcional tendo como ponto de vista os interesses de um grupo que se encontra no poder. Para um grupo que visa garantir sua supremacia em relação a outros, a política é a busca por apoio para sua causa. A guerra política, portanto, nada mais é do que a busca pela consolidação de apoio visando a vitória em um conflito direto. Embora o conceito seja normalmente aplicado para analisar as manobras políticas e de propaganda realizadas por um Estado contra um grupo que Ihe opõe (seja um outro Estado ou um grupo político), pode facilmente ser transposto para qualquer conflito entre dois grupos onde um deseje a eliminação (ou subjugação) do outro. Pode, portanto, ser aplicado para análise de políticas públicas quando as mesmas têm como intuito a subjugação de um grupo, social ou político, considerado como entrave para visão de mundo do agrupamento que implementa a política pública. Trata-se de identificar a tentativa modelar o comportamento político ou eleitoral de camadas da população, em especial quando ligado à expectativa de classes econômicas específicas, como, por exemplo, na apresentação de políticas públicas em anos eleitorais para aumentar a aprovação do candidato da situação.

Se a guerra política é a busca por apoio, então é de se esperar que as operações psicológicas também envolvam agentes externos ao grupo que busca impulsionar a guerra política em questão. O uso de agentes externos resulta tanto do sucesso prévio de 
adquirir aliados como da própria natureza das operações psicológicas. Uma mensagem oficial do governo pode ganhar muito mais credibilidade quando repetida por pessoas não ligadas ao governo, e portanto tidas como neutras na disputa política que se realiza. Ainda, um agente externo pode dar opiniões que não correspondam à verdade sem que isso resulte na perda de credibilidade do governo.

O uso de agentes externos para passar mensagens extraoficiais que favoreçam ao governo sem o comprometer com o que foi dito é denominado Propaganda Cinza. Mais uma vez Codevilla oferece uma descrição de como funciona a propaganda cinza, utilizando um exemplo histórico:

\begin{abstract}
Os Estados Unidos escolheram, com razão, falar ao mundo não apenas por meio de representantes oficiais. Em todo o mundo, a Agência de Informações dos EUA fornece palestrantes e programas que não refletem necessariamente as opiniões do governo dos EUA, de modo que os estrangeiros compreenderão tanto a amplitude da opinião responsável nos Estados Unidos quanto sua unidade em assuntos essenciais. Da mesma forma, a Liberdade da Voz da América e da Rádio da Europa Livre / Radio Liberdade fala, obviamente, graças aos fundos do governo dos EUA, mas em nome de algo maior do que o governo dos EUA. Essa ampliação semioficial da voz dos Estados Unidos no exterior é chamada de propaganda cinza(CODEVILLA, 1989; p. 79 e 80).
\end{abstract}

Codevilla avaliou o impacto da propaganda cinza nos anos (19)50, em especial para propagar a mensagem à Alemanha Oriental, Polônia, e Hungria, que os EUA apoiariam os povos que se levantassem contra o socialismo. No entanto, quem afirmava isso eram agentes que não representavam oficialmente os EUA. Não havia, portanto, um compromisso com o que se afirmava. Ainda, sequer precisava analisar seriamente a possibilidade de ter que intervir militarmente naqueles países. Assim, o governo americano, nas palavras de Codevilla, possuía a liberdade da irresponsabilidade. Podia jogar com a vida dos cidadãos daqueles países que, ao se mobilizarem, acreditando nas mensagens das rádios, palestrantes, e insufladores americanos, foram abandonados à sua própria sorte. Tudo para desestabilizar o poder soviético naqueles países.

Evidentemente, identificar a propaganda cinza em guerra política realizada dentro do escopo de disputas geopolíticas é bastante mais fácil do que o fazer quando se trata de disputas sociais internas dos países. Ainda mais quando estamos discutindo a disputa pelo espaço público. Mas, pode-se dizer que toda vez que um jornal ou âncoras de canais 
de televisão defendem projetos de revitalização, de policiamento extensivo, de embelezamento ou limpeza da cidade, classificando a apropriação espontânea da população como "vandalismo", "delinquência", "vagabundagem"23, etc., buscando jogar parte da população contra outra, trata-se de uma propaganda cinza. Nessa situação, a mídia acusa pessoas de serem criminosos sempre que realizam uma intervenção perturbadora no espaço público, sem precisar ter o compromisso de definir qual foi o crime, ou de apresentar provas que haja sido cometido qualquer crime. Apenas omite uma opinião sobre o ocorrido, e classifica os participantes do ato como criminosos, e, portanto, que deveriam ser retirados do convívio social.

Para o caso específico do Detecta, pode-se afirmar que houve propaganda cinza (ampliação semioficial da propaganda alinhada à política do Estado) toda vez que a mídia defendeu a ampliação e aprimoramento do sistema de videomonitoramento durante a época que o governo do Estado estava investindo no Detecta. Nessas condições, a propaganda servia para criar a sensação que o investimento significaria uma melhoria da segurança pública em São Paulo, sem que se discutisse a viabilidade do projeto (que se demonstrou, mais tarde, inviável), ou sobre os pontos negativos que o mesmo videomonitoramento poderia ter se usado por uma polícia corrupta, por exemplo. Era também propaganda cinza toda vez que se classificava manifestações políticas de vandalismo. Formava-se base para ampliação do apoio ao Detecta, e desincentivava a tentativa de parte da população de utilizar o espaço público para manifestar seus anseios políticos ou culturais por métodos considerados perturbadores da ordem social.

Alguns mecanismos de operação psicológica são facilmente reconhecíveis, pois, na literatura sobre o tema, eles já foram classificados e explicados. A classificação da propaganda através do agente que a produziu ou divulgou é mais trabalhosa. Mas a identificação através do conteúdo e do público-alvo é mais fácil. Ron Schleifer ressaltou que em geral o tema da propaganda está diretamente ligado ao público-alvo que se

23 Entre 2012 e 2017, o jornal “O Estado de São Paulo”, relatou diversas pichações em São Paulo. Algumas tinham claro conteúdo de protesto ou de intervenção política ou cultural. As pichações da praça Roosevelt (2012), da sede do Palmeiras (2012), do Monumento às Bandeiras (2013), Catedral da Sé (2015), novamente o Monumento às Bandeiras (2016), a calçada do escritório de Michel Temer (2016), do Centro de Treinamentos do São Paulo (2017), foram todos classificados pelo jornal ou como "vandalismo", ou "sujeira”. Em 27 de janeiro, em apoio ao programa Cidade Linda, de João Dória, o mesmo jornal lançou o editorial: "Pichação é, apenas, crime”. Ainda, é significativo que a reportagem sobre uma jovem enquadrada na Lei de Segurança Nacional, em 2013, por portar uma câmera fotográfica e tinta, próximo a um protesto onde houve pichação e depredação de uma viatura, tenha sido classificado pelas palavras-chaves: "Protesto, manifestação, Black blocs, vandalismo”, sendo que a reportagem trouxe o depoimento da jovem alegando que ela era apenas uma artista. 
deseja atingir:

Nesses casos, as meta-mensagens são transmitidas para os públicos-alvo. Temas para o público doméstico incluem: demonização do inimigo (o diabo encarnado); definir e justificar os objetivos da guerra; construção de confiança na capacidade do governo, nação e forças armadas para alcançar os objetivos da guerra. Para o público inimigo: uma divisão entre a liderança e os cidadãos e entre os cidadãos e o exército; induzir a desmoralização; minar a legitimidade da luta; implantando sentimentos de culpa nos soldados, levando para suas casas a futilidade da guerra. Para o público neutro: argumentos para a justiça e moralidade da guerra; e, como afirmado, esforços para ganhar seu apoio, ou, pelo menos, impedir que ele se alinhe com o inimigo (SCHLEIFER, 2014; p. 14 e 15).

Schleifer, portanto, identificou que, para o público aliado, a propaganda é feita a fim de demonizar o inimigo, fazendo com que desapareça qualquer possibilidade de empatia com o adversário. Ainda, é necessário garantir aos seus aliados que o conflito resultará em vitória, minimizando os riscos de baixas ou da derrota. Ainda, busca-se aumentar a identificação entre a população e o exército (ou lideranças políticas), de forma a fortalecer a "unidade nacional". Vê-se, dessa forma, que a propaganda voltada aos aliados têm como objetivo principal impedir a debandada de aliados, seja pelo medo da derrota, ou pela empatia ao inimigo. Na Guerra do Vietnã, por exemplo, tanto a mutilação dos veteranos de guerra quanto as imagens do horror da chacina de vietnamitas pesaram para perda de apoio dentro dos Estados Unidos. A propaganda aos aliados, portanto, é preventiva, e visa garantir a base de apoio para continuidade da política (ou guerra) que se pretende realizar. Para o público adversário, os temas são justamente o oposto. Visase demonizar a liderança do adversário, criando uma cisão entre os interesses da massa que o apoia e o exército que o sustenta. Visa-se ainda fortalecer a sensação da derrota certa, e que o conflito é fútil. Dessa forma, o objetivo da propaganda ao adversário é diminuir sua base de apoio e desmoralizar os combatentes, diminuindo sua capacidade de resistência. Para população neutra, o objetivo é duplo: por um lado, deseja-se diminuir a empatia que ela possa ter quanto ao inimigo. Por outro, é necessário passar a imagem que a guerra é justa (e portanto inevitável). O objetivo, na prática, é o de diminuir a pressão emocional, dando caráter racional ao conflito. Isso porque quem é neutro não possui, a princípio, sentimentos negativou ou positivos para qualquer um dos lados. Daí a inutilidade de demonizar o adversário para quem tem uma postura neutra. 
Quando se trata da disputa interna em um país, como na disputa pelo espaço público, os alvos e conteúdos das propagandas são exatamente os mesmos. É a vontade de demonizar o inimigo que faz com que pichadores sejam chamados de "vândalos" (ainda que não tenham causado dano permanente). Também é prática comum a divisão dos manifestantes em dois grupos: os "pacíficos" e os "vândalos" (ou black blocs) ${ }^{24}$. Se a guerra política deve ser compreendida em sua totalidade, é fundamental identificar o conjunto de medidas tomadas por um secretário de segurança como parte de um mesmo projeto político. Ou seja, não existe separação definitiva entre a criação de um projeto que, em tese, implementaria a identificação de "pessoas de interesse" (criminosos conhecidos), e a criminalização da liderança de atos políticos. Na verdade, fazem ambos parte do mesmo projeto de eliminação da oposição e do contraditório. A afirmação de Alexandre de Moraes relatada pelo o Estado de São Paulo, em 14 de janeiro de 2016, é um bom exemplo de esforço do então secretário de segurança de São Paulo para demonizar o adversário. Disse ele: "As lideranças do Movimento Passe Livre acobertam os black blocs. As lideranças têm ligação com essas pessoas e isso será investigado". Nota-se que Alexandre de Moraes declarou que o MPL era culpado antes mesmo de sequer investigar o tema. Portanto, sua intenção não era a de levantar uma suspeita. Aparentemente, foi um esforço de, ao mesmo tempo, demonizar o inimigo, e de criar uma cisão entre os cidadãos (militantes pacíficos) e a liderança (MBL, acusado de ser ligado aos Black Blocs).

Quando se trata do conflito entre dois grupos distintos, toda operação política, toda operação bélica, e todas palavras proferidas possuem também uma dimensão psicológica que não se pode ignorar. Fazem tão parte da disputa quanto o confronto direto. E o confronto direto faz tão parte da guerra psicológica quanto uma declaração pública em um jornal. Carnes Lord chamou atenção para esse aspecto total das operações psicológicas:

Há uma dimensão psicológica no emprego de qualquer instrumento do poder nacional, incluindo enfaticamente a força militar em todos os níveis. Da mesma forma, grandes incrementos de poder militar e econômico necessariamente geram efeitos políticos. Ao pensar em guerra psicológica e política, a tendência tem sido pensar no conflito de ideias, ideologias e opiniões. No entanto, essa concepção é, na verdade, seriamente enganosa. A guerra psicológica e política são também sobre símbolos culturais e políticos, sobre percepções e emoções, sobre o

24 A manchete "Black Bloc se infiltra em ato contra redução da maioridade e ataca PM", de 13 de Julho de 2015, no jornal O Estado de São Paulo é um exemplo de esforço para criar "uma divisão entre a liderança e os cidadãos e entre os cidadãos e o exército", sendo, no caso, o exército no caso os militantes mais radicais. 
comportamento de indivíduos e grupos sob estresse, sobre a coesão de organizações e alianças (LORD, 1989; p. 16 e 17).

A afirmação de Carnes Lord que a guerra psicológica e política são também sobre símbolos culturais e políticos, sobre o comportamento de indivíduos, é elucidativa. A capacidade política dos grupos de influenciar o espaço e as populações depende diretamente da força política representar símbolos políticos e culturais importantes para população. Quando, no interior da sociedade surgem símbolos ou comportamento culturais que contrariam a expressão cultural de quem está no poder ele precisa ou ser reapropriado, ou destruído. Em sociedades altamente divididas, em especial quando a divisão é também étnica, como o Brasil, existem comportamentos culturais bastante distintos entre a elite e a massa da população. Alguns desses símbolos simplesmente não podem ser reapropriados pelo agrupamento que está no poder sem que a sociedade seja remodelada. Nessa situação, quem está no poder apenas pode realizar uma forte guerra psicológica para desmoralizar não apenas os grupos rivais, mas também os símbolos que eles representam.

Se a manifestação cultural pode fortalecer ou minar os grupos políticos, evidentemente há interesse de quem já está no poder para que o espaço público não seja aberto para expressão simbólica que o conteste. Daí a necessidade de criminalização de determinadas expressões culturais. Ainda, a manutenção do poder e do controle sobre o espaço é mais fácil se o espaço público deixar de ser o espaço para a livre manifestação. Caso o debate político e cultural se realize fora do espaço público, dentro de instituições específicas, e resulte na normatização do comportamento sobre o espaço, é mais fácil de garantir que os símbolos nocivos aos interesses da elite estabelecida não terão amparo. Isso significa que, para quem está no poder, é de maior interesse que as regras de comportamento no espaço público sejam normatizadas, e que a livre apropriação do espaço seja expurgada. Daí a tendência do esforço de justificar a assepsia do espaço (o que joga a política para fora do espaço público, tornando o mesmo apenas o local onde as normas de comportamento são impostas). Por outro lado, aqueles que não estão no poder, e tem poucas condições de participar dos das instituições formuladoras de regra, há maior interesse que os costumes e símbolos possam ser livremente propagados no espaço público, que se torna, então, local preferencial para o debate político. 
A disputa pelo caráter do espaço público (se é ou não o local da política, e se deve ou não ser plenamente normatizado) faz parte da guerra política entre os grupos sociais. Não se pode separar a disputa entre os grupos e a própria disputa sobre o caráter do espaço público. Quando um secretário de segurança demoniza a liderança de um movimento político que se manifesta principalmente através da disputa do espaço público, como Alexandre de Moraes fez em declarações à mídia em janeiro de 2016, quando acusou o MPL de acobertar Black Blocs, tudo está em jogo. Trata-se do embate entre duas visões de civilização completamente distintas. Cada política pública implementada, cada manifestação de rua, cada pichação política em cada esquina da cidade faz parte dessa guerra total entre duas civilizações irreconciliáveis.

\subsection{DEFINIÇÃO E OBJETIVO DA GUERRA TOTAL}

Em 1999, Qiao Liang e Wang Xiansui cunharam o termo "guerra irrestrita". Em sua obra, os autores ressaltaram que, com o aumento da complexidade da sociedade humana e com o desenvolvimento das novas tecnologias, surgiram dois processos distintos na ciência bélica. Apareceram as armas de novo conceito, que são armas de tecnologia avançada, muitas vezes ligadas à guerra não convencional. Tal novo conceito de armas:

(...) não há nada no mundo hoje que não possa se tornar uma arma, e isso requer que nossa compreensão de armas tenha uma percepção que rompa todos os limites. (...) A nosso ver, um crash do mercado de ações causado pelo homem, uma invasão de vírus de computador ou um rumor ou escândalo que resulta em uma flutuação nas taxas de câmbio do país inimigo ou expõe os líderes de um país inimigo na Internet, podem ser incluído nas fileiras de novo conceito de armas.(...)

O que deve ficar claro é que o novo conceito de armas está no processo de criar armas que estão intimamente ligadas à vida das pessoas comuns. Vamos supor que a primeira coisa que dizemos é: o surgimento de novas armas conceituais elevará definitivamente a guerra futura a um nível que é difícil para as pessoas comuns - ou mesmo para os militares - imaginarem (QIAO \& WANG, 1999; p. 25 e 26).

Qiao Liang e Wang Xiansui entenderam que o desenvolvimento da sociedade e das ciências (incluindo as sociais) permitiram o surgimento de técnicas de manipulação da vida cotidiana das pessoas. Hoje, os governos são capazes de causar quebras econômicas, espalhar boatos difamatórios, etc. Para eles, essas técnicas de manipulação 
fazem parte do novo conceito de armas, onde tudo que puder ser usado para desorganizar o funcionamento normal de seu adversário pode ser uma arma. Daí o termo guerra irrestrita. Trata-se da expansão da guerra para a vida cotidiana das populações, para além do campo de batalha identificável. Ainda, leva à inesgotabilidade da guerra. Ela não se restringe ao tempo de duração dos conflitos declarados. A guerra irrestrita é, de certo modo, onipresente e eterna. Para ela ocorrer, basta que haja grupos com objetivos distintos (ainda que não opostos). De forma mais clara, nas palavras daqueles autores: "Nesse sentido, não há agora nenhum domínio que a guerra não possa usar, e quase não há domínio que não tenha o padrão ofensivo da guerra" (QIAO \& WANG, 1999; p. 189). Isso quer dizer que todo conflito (econômico, político, social, etc.) tem a potencialidade de servir à guerra. O conceito da guerra total leva, portanto, aos governos e forças sociais se portarem como sempre estivessem em guerra, ainda que não estejam. O efeito para o espaço urbano é que há uma tendência do fortalecimento da arquitetura de guerra (GRAHAM, 2011), e do esforço para o controle das forças sociais que atuam no espaço. Nessas condições, é ainda mais tentador para os governos tratar o espaço público como um território (sob o qual ele deve ter controle).

Em certa medida, pode-se afirmar que o avanço das sociedades e tecnologias levou à expansão da capacidade de comunicação e a interligação entre as esferas da vida. Boatos, hoje, afetam rapidamente o valor de empresas, e possui impacto direto nas economias locais. Essa nova capacidade de comunicação elevou as operações psicológicas a novo patamar. Não é mais realizada por pequenas células independentes infiltradas no território inimigo. É realizada, também, no campo da internet, e nas mídias locais. Não demora mais meses para ter impacto. A difamação pode se espalhar, através de correntes de aplicativos de celular em velocidade instantânea. Daí, nos meios militares, se discutir aquilo que tem se denominado de Guerra de Quarta Geração (4GW, do inglês: "forth generation war").

Uma discussão bastante pertinente é até que ponto as guerras de quarta geração se delimitam nelas mesmas, e até que medida, na verdade, elas não fazem parte da guerra irrestrita (no termo chinês), ou guerras híbridas (nomenclatura americana). Ou seja, se discute se há um novo tipo de guerra, que substituiu o velho tipo de guerra, ou se houve aumento de importância de ferramentas não convencionais ao lado do velho tipo de guerra. O Coronel Steven C. Williamson produziu um bom resumo dessa discussão. 
Em sua obra "From Fourth Generation Warfare To Hybrid War", trouxe a descrição de Lind sobre algumas das principais características da guerra de quarta geração:

\begin{abstract}
Os quatro elementos que Lind acredita serem diferentes na $4 \mathrm{GW}$ em relação às gerações anteriores são: (1) Ordens de missão que permitem que pequenos grupos de combatentes operem dentro da intenção do comandante, mas mantenham um nível necessário de flexibilidade. A flexibilidade local direcionada pela orientação geral é essencial para a $4 \mathrm{GW}$, que é principalmente combatida de maneira dispersa em toda a sociedade do inimigo. (2) Uma dependência decrescente da logística centralizada que facilita o conflito mais disperso e o ritmo mais acelerado. Os guerreiros 4GW devem ser capazes de se defenderem em qualquer ambiente que operem. (3) Maior ênfase na manobra sobre o poder de fogo que nega a exigência tradicional de concentração de soldados e armas. Em vez disso, a $4 \mathrm{GW}$ depende do emprego de "forças ágeis pequenas, altamente manobráveis" que podem se misturar ao seu ambiente e evitar serem detectadas. (4) Colapsar o inimigo internamente, em vez de destruí-lo fisicamente, requer que os líderes da 4GW tenham uma grande capacidade de identificar e atingir os centros de gravidade do inimigo. Lind afirma que em $4 \mathrm{GW}$, a população do inimigo e até a própria cultura se tornam alvos (WILLIAMSON, 2009; p. 2 e 3).
\end{abstract}

Muitos aspectos da guerra de quarta geração na verdade já estavam presentes nas operações psicológicas. Na verdade, o que William S. Lind parece sugerir é a primazia de unidades especiais de confronto, que adotem técnicas guerrilheiras e de operações tecnológicas para destruir os adversários desde dentro. Essa concepção de guerra pode, a primeiro momento, parecer menos belicosa do que o uso de tropas convencionais. No entanto, sugere o uso de operações clandestinas para assassinato de liderança, difamação de grupos políticos, sabotagem da economia local, etc. Na prática, coloca em primazia a guerra de tipo clandestino, onde vale tudo para destruir não a população (ou liderança) rival, mas sua própria cultura.

Caso essa visão seja aplicada à gestão de conflitos internos nos países, a confusão entre operações psicológicas e conflito direto, sob a forma antiética da guerra de quarta geração, aponta para o caos social. Isso porque pode haver a indução à uso de "forças ágeis pequenas, altamente manobráveis que podem se misturar ao seu ambiente e evitar serem detectadas" (WILLIASON, 2009) no conflito político interno. Isso significa utilizar unidades infiltradas que operem à margem da lei para difamar, incriminar, ou, no limite, assassinar adversários políticos. Evidentemente, um Estado Democrático de Direito não pode (publicamente) chegar ao extremo do assassinato de rivais políticos. A menos que esteja a se falar de um país com tradição de eliminação física de líderes de 
movimentos populares através do uso de jagunços e grupos de extermínio (por vezes formados por policiais) $)^{25}$.

Apesar de Stephen Graham ter analisado o impacto das novas tecnologias de guerra pela ótica da chamada guerra de quarta geração, apontou que uma das exigências do novo modelo é que a gestão do conflito passe também pela gestão campo de batalha das cidades, combinando técnicas de guerra assimétricas (GRAHAM, 2011; 27 - 28). Coronel Williamson chamou a atenção para o caráter híbrido das novas guerras, com o uso de forças convencionais e não convencionais. Daí, em sua visão, não se tratar de uma guerra de quarta geração, mas sim de uma guerra híbrida, multimodal, onde a força militar convencional ainda se aplica:

\begin{abstract}
Mais e mais acadêmicos militares agora veem um futuro potencial de guerra multimodal, em que os adversários empregam várias capacidades, dependendo do ambiente, de seus próprios pontos fortes e das vulnerabilidades de seus inimigos. Esta forma de guerra não é nova. Em seu livro Triumph Forsaken, Mark Moyer explica a Guerra do Vietnã como uma guerra composta. Os nortevietnamitas empregaram muito eficazmente uma combinação de forças irregulares e convencionais para alcançar o estado final desejado. De fato, "historiadores notaram que muitas, se não a maioria das guerras, são caracterizadas por operações regulares e irregulares". A estratégia de guerra combinada permite que os líderes militares aproveitem os pontos fortes de cada tipo de força, aumentando a pressão sobre o espectro do conflito. Na maioria dos casos ao longo da história, embora vários tipos de forças tenham lutado simultaneamente sob coordenação estratégica, eles geralmente eram empregados em diferentes locais da área de operações. Guerras compostas criam uma forte sinergia estratégica, mas muitos começaram a ver uma maneira de melhorar ainda mais a guerra. Tanto Colin Gray quanto Max Boot argumentam que haverá menor delimitação clara nas categorias de guerra. Essa mistura de capacidades está sendo saudada como guerra híbrida (WILLIAMSON, 2009; p. 21).
\end{abstract}

Trata-se da mistura de tropas regulares, que atuam como força militar oficial, e grupos irregulares, composto por agentes das polícias e exércitos, e agentes privados recrutados para os grupos paramilitares ${ }^{26}$. Esses grupos operam nos limites da lei estabelecida, e poupam a força oficial do desgaste de imagem causado em trabalhos "sujos". Como essas forças paramilitares em momento algum são oficialmente apoiadas

25 Conforme informação disponível no site do MST, desde 2014, até março de 2018, foram assassinados pelo menos 24 líderes de movimentos sociais no Brasil, todos fora de São Paulo. No entanto, conforme o jornal Último Segundo, entre 2012 e 2013, uma investigação da polícia civil apontou que, em Guarulhos, 21\% dos assassinatos teriam sido cometidos por um grupo de extermínio formado por Policiais Militares. Em 02 de setembro de 2015, Alexandre de Moraes negou a existência de grupos de extermínio em São Paulo, mesmo havendo duas chacinas ocorridas no Estado, só naquele ano. Em 2017,

26 O novo estilo de guerra americano é velho conhecido de países que passaram pela experiência colonial 
pelas forças oficiais, suas ações são consideradas ilegais. Quando descobertas, podem até mesmo ser punidas pela sua ação. Dado seu caráter irregular, suas ações dificilmente podem ser apontadas como parte da política geral da guerra política. No entanto, são parte do efeito da demonização do adversário. Quando o adversário é constantemente apresentado como "o diabo em pessoa", no esforço de diminuir qualquer empatia para com ele, é de se esperar que um dos efeitos é que setores mais radicais podem levar o ódio criado às vias de fato.

$\mathrm{Na}$ disputa pelo espaço público, o esforço pela classificação de apropriação espontânea do espaço público como "ação de criminoso" tem como efeito colateral a criação do ódio social, que leva a agentes policiais tratar jovens que se mobilizam politicamente ou culturalmente como criminosos perigosos. Alguns exemplos do efeito do ódio contra determinados segmentos sociais são o assassinato de um jovem na zona sul de São Paulo, espancado pela PM após a dissolução de uma festa de rua, em abril de 2017; a agressão de estudantes e jornalistas nas jornadas de ocupação de escolas públicas, em conflitos entre a polícia e os estudantes nas ruas próximas das escolas ocupadas e nas próprias escolas, em 2016; e o sequestro e tortura de estudantes participantes dos movimentos de ocupação de escolas públicas, relatados pelos próprios estudantes ao jornal GGN, também em 2016. A existência do ódio entre as partes é um dos motivos da importância de entender a guerra psicológica no interior das disputas políticas dentro de uma sociedade. Em momentos de acirramento dos ânimos, ela facilmente pode degenerar em uma guerra irrestrita, com consequências bastante drásticas. A disputa subjetiva pode ter impactos objetivos irreversíveis.

\subsection{A GUERRA TOTAL E A REPRODUÇÃO DO PODER}

O uso abusivo (e arbitrário) da força contra parcelas da população também é, por si só, um instrumento de guerra psicológica. Serve para intimidar, humilhar, e dissuadir a população contra quem o abuso é praticado. Faz parte da chamada diplomacia coercitiva, quando a ameaça da agressão é usada como força motivadora para que o inimigo entre em acordo. Em outras palavras, é o uso do medo como mecanismo de impor a submissão. Ela só faz sentido, no entanto, se o medo for justificável. Alvin Bernstein fez alguns apontamentos sobre a relação entre a diplomacia coercitiva e a capacidade efetiva 
de imposição da coerção:

\begin{abstract}
Quando examinamos a diplomacia coercitiva e as ações militares limitadas como formas de guerra psicológica, devemos ter em mente o que os romanos compreenderam instintivamente: a eficácia de qualquer operação psicológica depende da percepção do inimigo sobre o que acontecerá a ele se ele não fizer como nós desejamos. Essa percepção é determinada, pelo menos em parte, pela maneira como já nos comportamos em situações semelhantes. Estimar com precisão os prováveis efeitos psicológicos de qualquer uma de nossas futuras implantações ou operações limitadas requer reaprender o que o Vietnã e Beirute nos levaram a tentar esquecer. A coerção da diplomacia e as operações militares limitadas são bem-sucedidas em grande parte porque nossas ações anteriores nos renderam a reputação de seguir e usar a força de maneira rápida e eficaz. Quando tais ações falham, a falha não pode ser autocontida. Isso torna o sucesso no futuro mais difícil, não importa o que digamos aos nossos inimigos em nossos panfletos ou nos nossos rádios (BERNSTEIN, 1989; p. 146 e 147).
\end{abstract}

O que o autor ressaltou, ao refletir sobre o papel do exército como estimulador de acordos entre nações, é que o sucesso de ações passadas tem impacto direto na capacidade de dissuasão dos exércitos em ações futuras. Um país cuja capacidade bélica seja reconhecida tende a exercer passivamente um efeito psicológico em seus adversários. Cada derrota sofrida por esse exército diminui esse mesmo efeito. Isso aponta para dois tópicos relevantes: (1) a necessidade de se escolher as ações com cautela, para evitar desgaste da imagem devido às derrotas; e (2) o fato das derrotas não serem autocontidas, e as vitórias possuem efeito cumulativo. Essa mesma regra vale para guerra psicológica aplicada às disputas internas.

Quando uma nova política de segurança pública é proposta, ela é julgada pelo sucesso das políticas anteriores e pela imagem que a polícia tem no momento de sua proposição. Os adversários constroem seus medos e expectativas sobre a nova política tendo como maior balizador as ações recentes. Assim, quando o Detecta foi proposto, por exemplo, havia a experiência da Secretaria de Segurança Pública do Estado de São Paulo na digitalização de documentos, usando novas tecnologias disponíveis, desde 2005. Não havia, portanto, a princípio, motivo para duvidar que a nova tecnologia do Detecta poderia ser implementada. A propaganda que em breve o Estado de São Paulo poderia estar sob vigilância inteligente, levando a lei instantaneamente para as ruas, foi tomada como crível pelo público-alvo aliado. Ao mesmo tempo, dado o histórico de truculência da polícia, em especial nas experiências recentes de 2013 a 2016, houve 
expectativa de manifestantes políticos que essa nova tecnologia seria usada contra eles. Disso resultou um clima de terror. Em 2013, por exemplo, o Movimento Passe Livre denunciou o Inquérito $\mathrm{n}^{0} 1 / 2013$, que segundo eles era ilegal porque era "feito para mapear as pessoas, fazer um grande banco de dados de manifestantes, uma lista de suspeitos a priori, pessoas que podem ser presas a qualquer momento, fazendo absolutamente nada, só porque já consta nesse inquérito". Em seu vídeo denominado "Pelo fim do Inquérito $n^{\circ} 1 / 2013$ ", denunciaram que policiais faziam vigia na frente das casas de manifestantes do movimento, na tentativa de coagir os mesmos a não participar de novas manifestações de rua.

Em 2017, no entanto, o Detecta perdeu sua credibilidade, uma vez que sua implementação não correspondeu aos anseios, conforme se verifica pelo relatório 17.941/026/2015 do TCE. Essa incapacidade de cumprir o prometido atingiu a própria imagem da polícia militar, a ponto de mesmo jornais que até o ano anterior apoiavam o Detecta, passarem a ser críticos dos projetos similares apresentados no Estado de São Paulo, como será melhor debatido no próximo capítulo. A lição que se tira desse processo é que se os projetos de segurança pública podem ter um impacto psicológico em favor do reforço da estrutura de poder, esse impacto também depende da capacidade direta de exercer o poder que os instrumentos de segurança possuem. Mais uma vez, fica claro a necessidade de entender o contexto anterior e posterior à implementação das políticas públicas para que se possa entender o caráter psicológico que elas possam haver exercido na guerra política interna.

O estudo de instrumentos de guerra psicológica tendo como objetivo o combate à "inimigos internos" não é novidade. Parte da literatura sobre guerra política e guerra híbrida toca na temática das populações excluídas e da contrainsurgência. Christopher Simpson, por exemplo, ressaltou:

Voltando aos desenvolvimentos metodológicos, os programas de guerra psicológica subscreveram o desenvolvimento de várias metodologias quantitativas que permanecem básicas para estudos de comunicação de massa e para o que é eufemisticamente denominado pesquisa de comunicação pública (isto é, relações públicas. (...). Agências militares e de propaganda também subscreveram esforços de Ithiel de Sola Pool, Wilbur Schramm e outros para conceber técnicas de pesquisa especializadas adequadas para derivar informações sobre a opinião pública e uso da mídia de populações "negadas", particularmente dentro da União Soviética. Essas técnicas têm uma aplicabilidade mais ampla para o estudo de subculturas hostis em geral - criminosos, os muito pobres, os muito ricos e assim 
por diante -, mas têm sido mais frequentemente empregadas em justificativas orçamentárias para programas de propaganda externa dos EUA (SIMPSON, 2015; p. 112 e 113).

Simpson, portanto, identificou que os estudos de comunicação voltado às subpopulações no interior de países rivais tinham aplicabilidade também para o combate a subgrupos no interior dos próprios Estados Unidos. No entanto, esses estudos em geral não eram apresentados como referente à temática do combate ao inimigo interno. $\mathrm{Na}$ verdade, até hoje não é comum que se discuta as disputas políticas internas pela ótica da guerra psicológica, da guerra política, híbrida ou irrestrita. Há grande resistência em se aceitar que as técnicas de destruição interna aplicadas contra forças estrangeiras podem ser aplicadas também na reprodução da estrutura social vigente nos países. Assumir que isso pode ser feito tem o impacto de escancarar que mesmo em democracias, a luta política entre as camadas se dá, na verdade, sob a forma de guerra entre grupos de interesses opostos. E quem está no poder possui uma capacidade maior de utilizar instrumentos de dissimulação e manipulação contra os seus rivais. Ainda, é dizer que essa manipulação pode sim ser feita de forma consciente e planejada.

Não é cômodo ter que assumir que as políticas públicas precisam ser avaliadas tanto pelo seu conteúdo apresentado como pelo impacto direto e indireto, e pelas intenções ocultas por trás deles. Torna o debate mais áspero, e força a saída do campo do abstrato. Não se trata mais de discutir, apenas, se a política proposta beneficia ou não a construção de um espaço público inclusivo, por exemplo. Torna-se necessário discutir também quais são os interesses dos agentes concretos que propuseram aquela política, e como esses agentes podem utilizar a política para reforçar sua influência na sociedade. Em tese, a ampliação da capacidade do Estado de combater a criminalidade é algo bom para todos. Na prática, quando parcelas da população são arbitrariamente classificadas como "criminosas", a mesma política pode mudar completamente de sentido. A forma como a política em questão foi noticiada também afeta o seu impacto na sociedade. As palavras escolhidas pelos jornalistas (ou assessorias de imprensa dos órgãos públicos) para descrever o projeto, e os exemplos usados para explicá-lo, também fazem parte do sentido geral da política. No caso, o Detecta, portanto, não é apenas o software (ou o banco de dados formado), é também o alarde feito ao redor dele. O Coronel Williamson mais uma vez explica a importância do impacto subjetivo das operações que possuam 
impacto direto ou indireto nas emoções das populações:

Enquanto EUA se envolverem [em operações psicológicas] direta ou indiretamente, precisarão de profissionais em todos os níveis que possam atuar em circunstâncias descentralizadas, incertas, complexas e ambíguas. Líderes seniores e juniores devem entender que as dimensões humanas são mais importantes do que quaisquer outros fatores na guerra e que, embora a tecnologia seja importante, ela raramente é decisiva. Além disso, nossos líderes devem estar preparados para formar e liderar coalizões eficazes, ao mesmo tempo em que entendem a história, a política, a cultura e a psicologia de parceiros e adversários. A complexidade das ameaças híbridas torna essencial que nossos futuros líderes entendam as implicações e as compensações entre a preparação e a realização de contrainsurgência, construção de parceiros, operações de estabilidade e manutenção de nossa vantagem convencional no combate. A nação terá que determinar que nível de melhoria no conhecimento e capacidade é necessário para equilibrar efetivamente sua capacidade de abordar todas as ameaças e desenvolver os recursos correspondentes necessários (WILLIAMSON, 2009; $p$. 26).

O coronel chamou a atenção para a importância da preparação e realização de contrainsurgência, construção de parceiros, e operações de estabilidade, ao lado da manutenção das forças convencionais, em um contexto em que as relações humanas são o fator decisivo. Quando se fala de guerra política, é disso que se está falando. Trata-se do esforço de antecipar a ação de subgrupos considerados hostis, e a tentativa de os influenciar. É o esforço para controlar as emoções que podem resultar no ganho de apoio a um ou outro lado, e mesmo induzir os adversários ao erro.

Evidentemente, a arma mais importante para isso é a comunicação. A influência sobre agentes da mídia, e a escolha cautelosa de notícias e informações passadas pelas relações-públicas dos órgãos é tão importante quanto a organização das tropas no espaço disputado. Se há uma disputa pelo espaço púbico em São Paulo, entre dois tipos de visão do papel do espaço público, então o sucesso da repressão policial depende também da imagem mantida pela polícia. Sem dúvidas, a mídia tem papel fundamental na construção dessa imagem. Nas palavras de William S. Lind:

As operações psicológicas podem se tornar a arma operacional e estratégica dominante na forma de intervenção de mídia / informação. Bombas lógicas e vírus de computador, incluindo vírus latentes, podem ser usados para interromper operações civis e militares. Os adversários da geração anterior estarão aptos a manipular a mídia para alterar a opinião doméstica e a do mundo, a ponto de o uso hábil das operações psicológicas, em algum momento, impedir o compromisso 
das forças de combate. Um dos principais alvos será o apoio da população inimiga ao seu governo e à guerra. Os telejornais podem se tornar uma arma operacional mais poderosa que as divisões blindadas (LIND, 2010; p. 16 e 17).

Quando se trata em desorganizar os grupos sociais considerados nocivos à ordem pública, o mesmo continua sendo verdade. Os telejornais podem ser mais importantes do que um batalhão da polícia. É absolutamente impossível para polícia acabar com a pichação (seja a pichação de protesto ou não). Jamais conseguirá impedir que jovem façam suas festas de rua, ou ocupem praças e escolas para se expressar politicamente, a não ser que realize uma chacina tão grande que pode destruir sua imagem de garantidora da ordem. Mas os telejornais conseguem, sem grandes dificuldades, colocar parcelas da população contra aqueles jovens, e mesmo justificar o abuso de autoridade por parte da polícia militar, até certo limite.

\subsection{GUERRA CULTURAL E PÓS-VERDADE.}

A eficácia das operações psicológicas como ferramenta de manipulação da população é tão grande que tem feito que a propaganda se torne, em curto prazo, mais importante do que a intervenção direta na sociedade. Isso significa dizer que, hoje, é mais importante criar uma narrativa do que se esforçar para a mudar, uma vez que a própria percepção das pessoas pode ter impacto imediato nas relações de poder. Se a população acreditar, por exemplo, que todo pedinte é um delinquente perigoso, o "esculacho" policial ${ }^{27}$ pode ser percebido como uma reiteração da ordem. Mesmo em casos em que os principais jornais do país se posicionam a favor da vítima, como no caso do assassinato da vereadora do Rio de Janeiro, Marielle Franco, em 14 de março de 2018, o ódio contra a população pobre leva ao surgimento de boatos difamatórios contra a vítima. No caso, foram espalhadas correntes em redes sociais que acusavam Marielle de ser ex-namorada de um traficante, e de defender facções criminosas. Buscava-se com isso afirmar que ela havia sido assassinada por traficantes, quando as investigações indicavam que havia envolvimento de policiais e milicianos. Caso não houvesse o ódio à vítima do "esculacho", a perseguição sistemática, e as chacinas, seriam descritos como aquilo que são:

27 Chama-se "esculacho" quando um policial espanca qualquer pessoa que possa ser, ou não, suspeita de ação criminosa, a liberando em seguida. 
agressão policial. A propaganda, portanto, pode transformar o aumento da insegurança em aumento da sensação de segurança.

Frank G. Hoffman ressaltou, em 2007, que cada vez mais a percepção tem maior peso do que os resultados na batalha física. Isso significa dizer que uma derrota pode se tornar uma vitória, e uma vitória uma derrota, a depender da percepção da população:

Outra implicação é a necessidade de incorporar o que pode ser a mudança mais significativa no caráter do conflito moderno, a exploração da mídia moderna para alcançar grandes massas e mobilizá-las para apoiar a causa de alguém. Precisamos aprender como nos envolver nessa porção em expansão do campo de batalha, para com efeito "manobrar contra a mente" de nossos oponentes e da população em geral. (...)

Temos que reconhecer que a percepção importa mais do que resultados no campo de batalha físico. O secretário de Defesa estava perfeitamente correto em um discurso de outubro de 2007, quando afirmou que "o sucesso será menos uma questão de impor a vontade e mais uma função de moldar o comportamento de amigos, adversários e, o mais importante, das pessoas no meio".(HOFFMAN, 2007; p. 51 e 53 )

Hoffman localizou um trecho do discurso do então Secretário de Defesa dos Estados Unidos da América, Robert M. Gates. O próprio secretário deixava claro: o sucesso será uma questão de moldar comportamentos. Não disfarçou que estava se referindo principalmente ao comportamento de aliados e da população neutra. $\mathrm{O}$ que o então secretário estava afirmando é que o resultado concreto das ações não importa, desde que o efeito subjetivo tenha sido alcançado. É o sucesso subjetivo que daria base para o aumento de influência do governo estadunidense.

A dissociação entre sucesso objetivo das políticas implementadas e a percepção sobre o sucesso também afeta o campo da luta interna. Hoje, as políticas públicas são, em curto prazo, mais importantes pela sua repercussão imediata do que pela sua aplicabilidade. Quando levado ao extremo, isso significa dizer que a política pública pode ser apenas de fachada, proposta como uma peça publicitária para afetar a população. Torna-se uma mentira oficial, voltada a fortalecer a posição do grupo que a propôs. Nessas condições, o próprio governo pode se tornar um promotor de fantasias e narrativas, em vez de se debruçar sobre a realidade concreta.

O uso de mentiras para manipular a população não é novidade. Durante a época 
do nazismo, o uso da propaganda marcada por mentiras e inverdades marcou o governo alemão. No entanto, não é apenas nos regimes fascistas que as inverdades se tornam instrumento de poder. Angelo M. Codevilla, por exemplo, discorreu sobre aquilo que denominou de Propaganda Negra, refletindo sobre a guerra psicológica na disputa entre EUA e URSS:

\begin{abstract}
Onde as fontes de influência na opinião pública e na tomada de decisões são mais restritas, a propaganda negra tem uma chance maior de ser significativa. No Terceiro Mundo, um artigo plantado em um jornal ou uma história simplesmente divulgada de boca em boca pode causar ou acalmar distúrbios. Assim, os agentes soviéticos precisavam injetar apenas um pequeno incitamento em novembro de 1979 em Islamabad, na forma de relatos de assassinatos de muçulmanos causados por americanos, para fazer com que uma multidão queimasse a embaixada americana no solo.

No entanto, os canais de propaganda sombria são importantes não apenas pelo que podem contribuir para qualquer campanha, mas principalmente porque cada canal é outro bunker, outra trincheira tomada em território inimigo. Algumas dessas trincheiras podem ser de enorme valor (CODEVILLA, 1989; p. 85).
\end{abstract}

Codevilla deixou claro que a propaganda sombria não se resume à mentira. A constituição de laços, conexões, e contatos faz parte da propaganda negra. Isso porque a mentira precisa de canais para conseguir se espalhar. Entre os possíveis canais, Codevilla insinua que estão influenciadores (pessoas com capacidade de espalhar difamação de boca a boca), e mesmo jornais. Trata-se de encontrar indivíduos e instituições dispostas a espalhar inverdades. Um canal de televisão, por exemplo, que esteja disposto a repercutir pronunciamentos oficiais sem checar a informação, é um canal em potencial para propaganda negra. No entanto, Codevill parece ter ressalvas quanto ao método, dando a entender que criar canais de propaganda negra é importante por ser uma trincheira em terreno inimigo, o que não é a mesma coisa que afirmar que se deve utilizar a mentira irrestritamente.

Para a disputa interna, um grupo social forma seus próprios laços de propaganda sombria enquanto ocupa postos importantes na mídia local, nas igrejas, nas organizações comunitárias. Ao se apresentar como expressão da vontade nacional, um grupo social ou político torna sua opinião em "opinião verdadeira". Essa posição, de grande credibilidade, serva para reproduzir toda espécie de mentiras, inverdades e difamações. Líderes religiosos e jornalistas de renome possuem a liberdade de falar sem precisar comprovar 
as informações que repassa, dado o grau de confiança depositado nos mesmos.

A manipulação através de inverdades, ou meia verdades, é uma ciência. Não se faz de forma inconsequência, sem calcular os efeitos. Até porque um canal de propaganda sombria pode ser queimado, quando a mentira se revela como tal. Ainda, a própria mentira deve ser montada de forma a parecer verdade. Uma propaganda, mesmo quando baseada em fantasias, precisa parecer verdade. Conforme Greg Simons, a verossimilhança é chave fundamental para que uma propaganda seja abraçada pela população como se ela expressasse a verdade:

\begin{abstract}
Elementos típicos de um conflito moderno de $4 \mathrm{GW}$ incluem alta tecnologia, terrorismo, uma base de operações transnacional ou não nacional, direcionamento explícito da cultura e dos símbolos culturais do inimigo, e a implantação através da manipulação da mídia de sofisticadas operações de guerra psicológica. Como o objetivo tático central da insurgência $4 \mathrm{GW}$ não é o confronto físico direto, mas, ao invés, desgastar a vontade do regime inimigo de sustentar a luta, a guerra se torna uma guerra de ideias e informações. Para serem eficazes, essas ideias e informações devem ser reconhecíveis e apelar para o seu público-alvo. Na batalha por corações e mentes, ideias que não parecem realistas, ou que não são expressas em idiomas e expressões culturais que sejam compreensíveis, serão rejeitadas de acordo na batalha por corações e mentes. Acessibilidade e inteligibilidade da informação, identidade cultural e história, e confiabilidade da fonte de informação, todos se tornam fatores importantes na divulgação de mensagens de forma eficaz (SIMONS, 2010; p. 398).
\end{abstract}

Para o autor, a confiabilidade da fonte de informação é apenas um dos quesitos para que a propaganda logre afetar a emoção da população. É necessário que a propaganda seja preparada de tal forma que apele à identidade cultural e à história local. Ou seja, a informação precisa parecer crível para quem escuta, e precisa atingir os fundamentos essenciais da estrutura de formulação de ideias e emoções daquela sociedade.

Em uma sociedade como a brasileira, onde a divisão social é profunda, existe mais de uma cultura. Efetivamente, a linguagem emocional da elite local e da massa pobre são bastante distintas. Isso significa que diferentes camadas tendem a ser afetadas de forma bastante distinta pelas inverdades veiculadas. Na verdade, tendem a se informar por mídias bastante distintas. Mas, diferentemente da disputa externa, a luta interna é caracterizada pela existência de uma força hegemônica que se estabeleceu ao longo da história do país. Isso faz com que a ideologia da classe dominante (e do grupo dominante) 
se torne também dominante. No Brasil, o discurso do ódio ao "vagabundo", ao "bandido", etc., perpassa todas as camadas sociais. A diferença é que os mais pobres sabem que podem, a qualquer momento, se encontrar no fogo cruzado entre a polícia (considerada racista e corrupta) e o "bandido".

A existência de dois brasis, mas com alguns símbolos em comum, permite que a propaganda baseada em mentira possa ser dividida em três tipos: às voltadas para unificar as camadas que se identificam com a elite local, em geral tendo como objetivo disfarçar derrotas e justificar excessos; às voltadas à população mais pobre (ligadas à criação de inimigos públicos, ou buscando convencer que políticas públicas aplicadas contra os pobres na verdade vai os beneficiar); e aquelas que afetam indistintamente os dois grupos, graças aos símbolos em comum.

Um dos problemas da inverdade como ferramenta de construção de percepção de realidade é que ela tende a se esgotar assim que se revela que era, na verdade, uma mentira. Essa tendência ao esgotamento, no entanto, pode não se realizar quando há perpetuação do ódio. A mentira, mesmo desmascarada, se reproduz como ferramenta de causar dor. Nessas condições, a mentira se torna ferramenta de identidade entre o grupo social que possui um ódio em comum. Deixa de ser um instrumento para adquirir novos apoiadores à causa que se deseja atingir, e passa a ser um instrumento de insuflamento dos apoiadores já possuídos. Acusar pichadores de terem resistido à prisão como justificativa para polícia os ter baleado, rapidamente se torna criticável quando o exame balístico mostra que o único policial ferido foi atingido por uma bala disparada por outro policial, por exemplo ${ }^{28}$. O tempo tende a revelar algumas das mentiras utilizadas na guerra psicológica. Por isso, toda ação baseada em mentiras deve buscar atingir seus objetivos antes que esse tempo se esgote, ao risco da mesma deixar de ser uma ferramenta de aglutinação de novos apoios e passar a se tornar um instrumento de identidade de grupo. Fred Ikle ressaltou a necessidade de se tomar cuidado com o uso abusivo de operações psicológicas em contextos democráticos:

28 Em 2017, por exemplo, cinco policiais militares acusados de assassinar dois pichadores, em 2014, foram absolvidos, havendo a juíza do caso reconhecido que eles agiram em legítima defesa. No entanto, revelou-se que o exame de balística indicou que o único policial ferido o foi por um tiro disparado por uma arma de um dos policiais envolvidos. Ainda, um dos pichadores foi alvo de 3 disparos realizados a queima roupa. O caso causou escândalo na época. Após a absolvição, a mídia inicialmente deixou de relatar as inconsistências do caso. Foi só após protestos que alguns jornais deram maior espaço para que a viúva de uma das vítimas e o Ministério Público explicassem as inconsistências. Após o esclarecimento, a opinião pública mudou de lado. Ver: https:/noticias.uol.com.br/cotidiano/ultimas-noticias/2017/11/25/absolvicao-de-pms-que-mataram-pichadores-edesumana-e-segunda-violencia-do-estado-diz-viuva.htm. 
Qualquer empreendimento democrático deve enfrentar o fato de que as comunicações modernas e a abertura democrática se combinam para garantir que as operações secretas não permaneçam ocultas por muito tempo. Jornalistas podem relatar instantaneamente de qualquer lugar do mundo, e porta-vozes adversários desfrutam de acesso imediato à mídia americana e internacional. $\mathrm{O}$ incidente de Hasenfus na Nicarágua ilustra o meu ponto. E os adversários do sistema político americano são capazes de usar sua abertura para promover seus interesses estratégicos. O comandante Daniel Ortega pôde viajar por todo o país fazendo lobby mesmo quando o Congresso votou ajuda militar contra ele (IKLE, 1989; p. 3 e 4).

O que Fred Ikle tentou chamar a atenção é que quando uma operação psicológica depende do sigilo, seja por ser baseada em mentiras ou por ter um caráter antiético, o ambiente democrático opera contra a mesma. Jornalistas e militantes rivais ao stabilishment podem expor a operação, fazendo com que ela cumpra o efeito contrário ao inicialmente desejado. Os adversários que se desejava dividir podem se unir, e a população que se deseja adquirir apoio pode passar a se opor, mediante a nova exposição.

Na disputa pelo espaço público, o uso de mentiras claras (aquelas que não podem ser disfarçadas de opinião) é mais raro. Mesmo quando usadas, a sua repercussão em geral leva ao descrédito do agente que a veiculou, e dificilmente gera desconforto geral com o governo ou com os grupos sociais beneficiados pela mentira. Afirmações como "O MPL tem ligações com os Black Blocs"29, "o MTST é ligado ao tráfico de drogas, conforme a polícia de São Paulo comprovou" 30 dificilmente são desmentidas publicamente depois de proferidas. Mesmo quando a mentira é óbvia, dificilmente elas são consideradas como um esforço consciente de atacar a imagem dos opositores ao regime. Seja como for, uma vez que a mentira é identificada como tal, dificilmente pode voltar a ser usada no debate público, em curto prazo. Nada impede, no entanto, que permaneça a ser usada dentro dos segmentos políticos. Exemplo disso foram os boatos de que o filho do Lula era dono da Friboi, acusação rapidamente desmascarada no debate público, mas que continuava a ser apresentada dentro dos círculos opositores ao Partido dos Trabalhadores,

29 Acusação proferida por Alexandre de Moraes em fevereiro de 2016, sem que jamais houve sido comprovada tal ligação.

30 Afirmação realizada por Rodrigo Constantino, em 04 de setembro de 2016, em seu artigo “A esquerda é criminosa e sempre será”. Na ocasião, Constantino atribuiu ao MTST acusação que dizia respeito ao MSTS. Ambos grupos eram rivais, havendo o MTST, por exemplo, construído boas relações com a prefeitura de Fernando Haddad, enquanto o MSTS fazia oposição ao prefeito. 
fortalecendo a coesão e o ódio daqueles círculos e dificultando a construção de debates públicos entre as partes.

Como, na disputa pelo espaço público da cidade de São Paulo, o governo e os grupos interessados contam com a mídia privada para divulgar e propagar informações e preconceitos, não há unidade total entre os agentes sociais envolvidos na operação psicológica. Se um funcionário do governo passa informação falsa e a mídia maliciosamente não a checa naquele primeiro momento, nada impede que a mesma mídia venha a questionar em um período posterior. Isso porque os interesses nem sempre são idênticos. Especialmente quando, além dos interesses políticos por trás das políticas públicas, haja interesses materiais. Políticas públicas custam dinheiro. Em muitos casos, empresas são contratadas para aplicá-las. Isso cria interesses dissonantes entre os grupos que disputam parte da verba do Estado. Essa disputa pode resultar em insatisfação entre os grupos que possuem interesse político em comum. Ainda, a mídia presa pela sua credibilidade, e sustentar algumas mentiras pode ter um custo social que os jornais não estão dispostos a pagar.

\subsection{CONFLITO ENTRE AGENTES}

O esforço por interpretar o impacto de operações psicológicas em uma disputa interna, ainda que se faça através do uso de categorias simplificadoras mais amplas, não pode fugir da responsabilidade de deixar claro que a disputa não se resume à apenas as ditas categorias. No nosso caso, isso significa dizer que a contradição entre a utopia da assepsia do espaço e a utopia da apropriação política e orgânica do espaço público é atravessada pela contradição entre os grupos que se encaixam em uma ou outra utopia. No caso das operações psicológicas, é necessário, portanto, identificar quais são os agentes envolvidos, se eles possuem unidade política ou se seus interesses diferem.

Ao longo desse capítulo, ressaltamos a importância da mídia na realização de operações psicológicas. Na América Latina, a relação entre os conglomerados midiáticos e os governos é bastante conhecida, em especial quando se tratou do apoio a ditaduras militares. O jornal $\mathrm{O}$ Globo, por exemplo, já admitiu ter apoiado e se beneficiado da ditadura militar de 1964 (O Globo: "Apoio editorial ao golpe de 1964 foi um erro", 
31/08/2013). É importante ressaltar que, na realidade da sociedade ocidental, alguns dos maiores veículos de informação não estão submetidos diretamente aos governos. $\mathrm{Na}$ verdade, como ressaltou Ignácio Ramonet, ocorreu, ao longo do tempo, um forte processo de concentração de propriedade dos meios de comunicação, criando verdadeiras oligarquias da informação:

\begin{abstract}
Em virtude da concentração excessiva dos meios de comunicação, a imprensa escrita está passando para as mãos de indivíduos que poderíamos chamar de oligarcas. Eles são donos de uma grande fortuna e, como os preços dos jornais impressos afundaram em razão da crise, podem comprar e dispor de publicações. Mas eles não fazem isso para ganhar dinheiro, pois, atualmente, ninguém ganha dinheiro (ou ganha muito pouco) com a imprensa escrita; esta é, antes, uma atividade onde se perde dinheiro. Então, para que as compram? Para ganhar influência, para ter um projeto ideológico, um projeto político, um projeto dominante (RAMONET, 2013; p. 53).
\end{abstract}

O trecho de Ramonet chama a atenção para o fato das oligarquias de comunicação possuírem interesses e projetos de poder próprios. São, portanto, agentes separados dos governos locais, podendo, inclusive, representar interesses de oligopólios internacionais contrários aos poderes locais. Ou, como oligarcas dos meios de comunicação, famílias locais podem ter interesse distinto de outros segmentos da elite do país. No que toca a utopia da assepsia do espaço público, é natural que as instituições de comunicação, devido sua larga influência na política institucional local, seja mais favorável à normatização prévia das relações com o espaço do que à livre apropriação. Assim, haverá tendência de colaborar com as instituições e forças políticas que defendam a retirada do embate político e cultural do espaço público. Essa colaboração, no entanto, sempre será limitada pelos interesses pessoais dos donos do meio de comunicação, e dos interesses comerciais do oligopólio que o controla.

Parte do controle realizado pelos oligarcas da comunicação, no entanto, tem sido driblado através do uso de pequenos jornais, páginas de internet, e chamados "influenciadores". O advento das redes sociais na internet tem permitido que as operações psicológicas atinjam um número maior de indivíduos sem precisar passar pelas mídias tradicionais. No entanto, é enganoso achar que a internet é um ambiente neutro. $\mathrm{Na}$ verdade, as grandes empresas por trás dos principais sítios virtuais também possuem interesses próprios, e podem colaborar ou não com os interesses dos grupos políticos que 
estão no poder. Ramonet chamou a atenção, no entanto, que tem se formado uma aliança entre os proprietários dos grandes sítios de internet e o Estado (norte-estadunidense):

De certo modo, a vigilância foi "privatizada" e "democratizada". Não é mais uma questão reservada apenas aos serviços de informação do governo. Embora, graças também à estreita cumplicidade que os Estados tiveram com as grandes empresas privadas que dominam as indústrias de computadores e telecomunicações, sua capacidade de espionagem em massa cresceu exponencialmente. (...)

Esta aliança sem precedentes - Estado + aparato de segurança militar + gigantes indústrias da Web - criou este Império de vigilância cujo objetivo claro e concreto é colocar a Internet sob vigilância, toda a Internet e todos os usuários da Internet (RAMONET, 2016; p. 12 e 13).

Ignacio Ramonet discorreu sobre a vigilância na internet. Apontou que hoje, a maior parte das informações adquiridas pelos órgãos de segurança dos estados o são através da internet. Isso é feito através de dois principais mecanismos. Parte das informações são conscientemente oferecidas pelos usuários de internet, que os colocam à disposição em suas páginas em redes sociais. Basta que uma empresa utilize um software de coleta de dados para montar um banco de dado próprio. No entanto, parte das informações obtidas pelos governos e empresas é adquirida através de parcerias pouco transparentes com os gestores das redes sociais. Aplicativos de celular, páginas de internet e mesmo sistemas operacionais coletam informações que não foram disponibilizadas ao público, incluindo mensagens de texto privadas, conversas através de áudio, e mesmo sons ambientes ${ }^{31}$.

Como já ressaltado, parte das operações psicológicas é a pesquisa e análise do ambiente emocional das populações alvos de possíveis operações futuras. A informação coletada permite (a) formular mais adequadamente a propaganda; (b) verificar o impacto da propaganda, buscando detectar necessidade de adaptação da operação; e (c) identificar mudanças espontâneas no ambiente emocional. Evidentemente, isso é mais fácil com o uso das novas tecnologias de informação. No entanto, tem também formado novos agentes sociais, que são as empresas especializadas no assunto. Ainda, parte dos

31 O sistema operacional Windows 10, e os aplicativos desenvolvidos para ele, declaradamente coletam dados dos usuários, conforme estabelecido no contrato de uso. Empresas especializadas em segurança de rede, como a AVG, denunciam e ensinam a diminuir a coleta de dados feitas pela microsoft: https://www.avg.com/en/signal/windows10-privacy-everything-you-need-to-know-to-keep-windows-10-from-spying-on-you. Ainda, o uso de smartphones e smartTVs para coleta de informações foi denunciada pelo WikiLeaks. Sobre o assunto, ver reportagem do Washington Post: https://www.washingtonpost.com/news/the-switch/wp/2017/03/07/why-the-cia-is-using-your-tvssmartphones-and-cars-for-spying/?utm_term=.1f744b64ccdf. 
jornais tem acompanhado os ambientes virtuais a fim de permitir um posicionamento que eleve sua capacidade de influência na população. É possível que esse novo cenário tenha dificultado o prolongamento da unidade entre os grupos e indivíduos que disputam poder em torno de projetos comuns.

Ao mesmo tempo, a multiplicação de mecanismos de vigilância, e no número de instituições e agentes capazes de espionar a vida dos cidadãos, tem contribuído para criação de um clima de paranoia. A hipótese de que um governo seja capaz de realizar a vigilância total sobre seus cidadãos, tem sido cada vez mais levada a sério. Em parte, esse mesmo clima contribui para que programas de vigilância inteligente, com o Detecta, embora tenha dificuldades técnicas reconhecidas, seja utilizado como propaganda para amedrontar lideranças de movimentos sociais. Um dos resultados é possível esforço para evitar se expor, que faz com que ativistas radicais se portem como se estivessem clandestinos, diminuindo sua capacidade de inserção social. Parte dos partidários do livre debate político e livre produção cultural nos espaços públicos, ainda hoje, é movida pelo medo da constituição de uma sociedade totalitária controlada por governos e pelas grandes corporações. Em sua obra, Ignacio Ramonet ressaltou esse clima de receio:

As pessoas lembram-se das advertências lançadas no passado por George Orwell e Aldous Huxley contra o falso progresso de um mundo administrado pela polícia do pensamento. Elas temem a possibilidade de um condicionamento sutil das mentalidades em escala planetária. No grande esquema industrial concebido pelos proprietários das corporações de lazer, todos observam que a informação é considerada, acima de tudo, como mercadoria; e que esse personagem vence, de longe, a missão fundamental da mídia: esclarecer e enriquecer o debate democrático (RAMONET, 1998; p. 165).

Dada a multiplicidade de instituições e grupos envolvidos no mundo da informação, hoje é bastante custoso ao cidadão identificar quem está por trás da informação veiculada e quais os interesses de quem a produziu. Mas identifica-se que toda informação tem um interesse por trás, inclusive a veiculação de fatos comprovados. A certeza de que há interesses não revelados, somada ao medo de ser manipulado, leva à busca de narrativas cômodas. Trata-se de ambiente bastante favorável àquilo que se denomina "pósverdade", que nada mais é do que uma mentira que, ao corresponder a anseios emocionais da população é tomada como verdade. A pós-verdade também afeta a disputa 
do espaço público, uma vez que facilita a difamação de agrupamentos e comportamentos que se deseja extirpar do espaço, auxiliando a transformação do espaço público em território das forças de segurança do Estado.

No caso do Detecta, a proposta inicial apresentava dificuldades técnicas de aplicação. Entre elas a necessidade de uso de câmeras de alta qualidade, base de dados robusta, capacidade de vetorização de imagens e também a necessidade de capacidade de processamento de informações em tempo real ${ }^{32}$. Todas essas dificuldades técnicas já eram conhecidas por especialistas no tema. No entanto, foi necessário o Tribunal de Contas do Estado de São Paulo localizar, em 2016, incompatibilidade entre aquilo que a Secretaria de Segurança Pública de São Paulo afirmava e os dados disponíveis para que a farsa do programa Detecta fosse revelada. Parte do sucesso da propaganda em torno do videomonitoramento inteligente se explica pelo medo (e pelo sonho) de que estejamos próximos de nos tornarmos um mundo orwelliano.

32 Para o levantamento de alguns dos problemas ainda enfrentados pela atual tecnologia monitoramento inteligente, ver: XU, Li-Qun. Issues in video analytics and surveillance systems: Research/prototyping vs. applications/user requirements. In: Advanced Video and Signal Based Surveillance, 2007. AVSS 2007. IEEE Conference on. IEEE, 2007. p. 10-14; FORESTI, Gian Luca; MÄHÖNEN, Petri; REGAZZONI, Carlo S. (Ed.). Multimedia video-based surveillance systems: Requirements, Issues and Solutions. Springer Science \& Business Media, 2012; DEE, Hannah M.; VELASTIN, Sergio A. How close are we to solving the problem of automated visual surveillance?. Machine Vision and Applications, v. 19, n. 5-6, p. 329-343, 2008. 


\section{A UTOPIA DE UM O VIDEOMONITORAMENTO INTELIGENTE EM SÃO}

PAULO

Nossa hipótese é que o Detecta, programa de videomonitoramento inteligente, foi utilizado, também, como uma peça da operação psicológica para o controle do espaço público de São Paulo. Se esse foi o caso, então há de ser possível observar padrões de batalha informacional pela divulgação do Detecta. Nessas batalhas, as informações e agentes podem ser definidos como (a) parte da propaganda oficial; (b) parte da propaganda cinza (que serve aos interesses dos agentes oficiais, mas que é aplicada por agentes independentes); ou (c) peças de contradição à propaganda.

Como as empresas de jornal no Brasil não são diretamente controladas pelo Estado e possuem interesses próprios, é sempre possível que ela participe de parte da guerra psicológica contra a apropriação espontânea do espaço, mas se oponha à peças específicas de propaganda do Estado. Em parte, isso se explica pelo interesse dessas empresas de manter certa credibilidade. Nessas condições, parte do esforço da secretaria de segurança pública do Estado de São Paulo, e do próprio governo do Estado, teria se caracterizado pelo esforço de responder a mídia local, como buscaremos demonstrar nesse capítulo. Daí ser possível verificar padrões de batalha informacional, onde um lado realiza ofensivas informacionais e outro assume a defensiva, na relação entre a secretaria de segurança pública e os jornais locais.

No presente capítulo, será demonstrado que ao videomonitoramento inteligente foi apresentado, pelo governo de São Paulo, como uma promessa de um mundo de vigilância total do espaço público. Essa utopia de uma cidade onde o conflito seria expurgado do espaço público não foi inteiramente comprada pelos principais jornais. Não por criticar possíveis efeitos negativos, mas sim por, desde o primeiro momento, haver sido detectadas falhas técnicas que tornavam o programa pouco mais do que um sonho. $\mathrm{Na}$ verdade, a mídia local apoia o uso de videomonitoramento para punir e desestimular a apropriação espontânea do espaço, em especial quando ocorre sob a forma de pichação, manifestações de rua (populares), e intervenções artísticas não autorizadas (e críticas ao sistema político vigente). 


\title{
3.1 DETECTA: UM PROGRAMA PROMISSOR OU UM PROJETO NATIMORTO?
}

Em abril de 2014, a Secretaria de Segurança pública divulgou a criação de um programa que analisaria automaticamente imagens de câmeras de segurança, utilizando um vasto banco de dados sobre a população. Tratava-se do programa Detecta, que era uma adaptação do sistema de videomonitoramento originalmente desenvolvido para cidade de Nova lorque. Na época, o então secretário da segurança pública era Fernando Grella ${ }^{33}$. Em parte, o programa foi apresentado como uma solução para os altos índices de criminalidade do Estado. No entanto, em pouco tempo se tornou uma espécie de promessa da secretaria de segurança de um futuro sem crime e também sem "caos urbano", conforme retrata em jornais como Brasil 247 (Brasil 257: "Mesmo em teste, Detecta ajudou a coibir o caos em São Paulo, 23/06/2018).

Ao primeiro momento, o programa foi anunciado de forma bastante enigmática e sem grandes repercussões. A própria secretaria de segurança não fez alarde sobre aquilo que estava criando. Na verdade, nem mesmo afirmava ter criado um programa novo. Em seu sítio de internet, a secretaria de segurança pública divulgou uma nota que explicava alguns aspectos do Detecta:

\begin{abstract}
Para dar maior eficiência ao planejamento do patrulhamento das vias públicas e das investigações criminais, São Paulo está implantando a nova fase do Detecta, sistema inteligente de monitoramento criminal. Nela, o sistema foi aprimorado para ser o mesmo utilizado pela polícia de Nova lorque há 7 anos. A experiência na cidade norte-americana desenvolveu alertas para 10 mil padrões de crimes. Esses alertas podem ser alterados, modificados para a realidade brasileira e podem ser adicionados novos alertas. (...)

A nova etapa do Detecta contribuirá ainda com o planejamento das ações policiais, pois permitirá a identificação de padrões de crimes praticados em cada região a partir dos registros realizados. Então será possível saber com precisão datas, horários e locais em que mais acontecem determinados crimes em cada região, além de possíveis migrações ou mudança de atuação da criminalidade. ( SSP: "Mapa de Crimes", 17/04/2014, http://www.ssp.sp.gov.br/acoes/leAcoes.aspx? $\mathrm{id}=33833$ )
\end{abstract}

A secretaria apresentou, portanto, o início da "nova etapa do Detecta", programa que na verdade foi criado naquele mês. Ainda, afirmava que o programa estava sendo

33 A política de segurança do Estado de São Paulo, da época, era fortemente criticada. Durante os anos de 2013 e início de 2014, a polícia militar de Fernando Grella foi criticada por reprimir manifestações com uso excessivo da força, e mesmo por plantar provas. Ainda, como o Estado ainda continuava com alto índice de criminalidade, parte do jornalismo, incluindo Luis Nassif, apelido ou então secretário de "Secretário da (in)segurança”. 
"aprimorado" para ser "o mesmo" do utilizado pela polícia de Nova lorque. Esse programa "aprimorado" seria capaz de identificar os crimes, georreferenciá-los e identificar até padrões de migração do crime. A promessa, portanto, é que a polícia agora seria capaz de utilizar as câmeras de segurança de forma mais eficiente, e conseguiria até mesmo elaborar planos estratégicos para prevenção de crime. Não atoa a nota se chamava "mapa de crimes". Assim a secretaria via naquele momento o Detecta.

É curioso notar que, no dia anterior, 16 de abril de 2014, a empresa Microsoft anunciou em seu sítio de internet que o Governo do Estado de São Paulo havia adquirido o software Detecta, desenvolvido por ela em parceria com a prefeitura de Nova lorque ${ }^{34}$. A empresa Microsoft se esforçou mais do que a secretaria de segurança pública de São Paulo para explicar o que era o Detecta e como seria instalado. Explicou que no convênio traçado, os três primeiros meses seriam dedicados à adaptação e treinamento de equipe, por exemplo. Ainda, explicava no que consistia o programa: a combinação de um Big Data $^{35}$, com o Business inteligence ${ }^{36}$. Conforme a notícia da Microsoft, em agosto o programa Detecta estaria em fase de implementação.

Em agosto de 2014, o jornal Diário de São Paulo noticiou a implementação do programa, trazendo uma declaração do então secretário de segurança pública. Os trechos selecionados da notícia, abaixo, revelam um ponto de vista sobre quais eram os principais pontos do programa: (a) um software de levantamento de ocorrências criminais, em tempo real, que seriam georreferenciadas; (b) um mecanismo que uni levantamento de imagem à comparação com base de dados; (c) um poderoso mecanismo de integração do videomonitoramento; e (d) uma ferramenta de modificar a realidade:

\footnotetext{
Buscando diminuir os casos de roubos e furtos na capital e nos grandes municípios do interior, que têm apresentado alta nos últimos indicadores criminais, o governo do estado colocou para operar, ontem, o Detecta.

O sistema inteligente de monitoramento criminal une as bases de dados da polícia e outros órgãos públicos e privados, além de câmeras de segurança, para atuar contra a criminalidade. (...) Segundo o governo, até o fim do mês o Detecta terá incorporado as 593 câmeras que a PM tem acesso no estado, sendo que 418 são da própria corporação (352 na capital) e 173 são da GCM (Guarda Civil Municipal). (...) Segundo o secretário de Segurança Pública de São Paulo, Fernando Grella,

34 Ver: https:/news.microsoft.com/pt-br/parceria-entre-governo-de-sp-e-microsoft-amplia-acoes-de-inteligenciapolicial/ , última visualização, 10 de abril de 2018.

35 Banco de dados que contém enorme quantidade de dados brutos, organizados e indexados por tipos, o que facilita sua análise estatística.

36 Processamento de informação de acordo com regras específicas que gerem um padronizado único.
} 
'São Paulo é o primeiro estado a utilizar uma ferramenta de Big Data no combate ao crime'. Ontem, o vice-presidente de serviços para setor público da Microsoft, Mike McDuffie, disse que a missão do Detecta é facilitar o acesso a tecnologias que ajudem a transformar a realidade. (Diário de São Paulo: "Detecta começa a ajudar a polícia”, 14/08/2014)

A proposta de modernização do videomonitoramento era uma das esperanças que o governo tinha para mudar a imagem do governo do estado. A imagem que se buscava passar era que o Detecta traria a alta tecnologia de segurança de Nova lorque, desenvolvida pela Microsoft, para São Paulo. Essa tecnologia era descrita como uma ferramenta para que a polícia conseguisse ter um mapa, em tempo real, dos crimes ocorridos nas cidades, em especial na capital. Ainda, seria possível ver as imagens da câmera, identificando os criminosos.

Se o programa funcionasse conforme o proposto, significaria potencialmente o controle total da polícia sobre o espaço. Seria a possibilidade da afirmação da normatização do espaço público. Era uma resposta ao "caos urbano" e fortalecia a esperança de que um dia a cidade estaria livre de perturbações. A imagem que se buscava criar era, portanto, de um espaço asséptico, livre de "insegurança".

As declarações de Fernando Grella sobre a implementação do programa foram noticiadas por pequenos jornais, como o próprio Diário de São Paulo, e A Tribuna, onde afirmou: "O Estado de São Paulo tem a primeira polícia no Brasil que associa automaticamente os seus bancos de dados em tempo real. Além disso, São Paulo é o primeiro estado a utilizar uma ferramenta de Big Data no combate ao crime" (A Tribuna: "Nova etapa do Detecta entra em operação para monitorar crimes", 12/08/2014). Naquele momento, jornais de pequena proporção serviram como agentes de propaganda cinza, repercutindo informes e declarações do secretário da segurança e da polícia militar. Começava, naquele momento, a operação psicológica em torno do Detecta.

Em 17 de setembro de 2014, o jornal Brasil 247, e relatou o uso do Detecta para tomada de decisão e para coordenação do efetivo policial na ocasião de uma reintegração de posse realizada no dia anterior. A reportagem se prestou a, principalmente, dar voz ao comando da polícia militar: 
Mesmo em fase de implantação, o Detecta ajudou a Polícia Militar ontem na operação de reintegração de posse no centro da capital de São Paulo. Em meio às cenas de guerra que sacudiram o centro velho da cidade, as câmeras do Detecta focalizaram vândalos e estão contribuindo para a identificação objetiva desses depredadores.

A informação é do coronel Glauco Silva de Carvalho, comandante do CPC (Comando de Policiamento de Capital) responsável por toda a operação no Centro de São Paulo.

'Com o Detecta foi possível orientar o deslocamento de todo o nosso efetivo e dos homens da Tropa de Choque.', diz o coronel. 'O Detecta foi muito importante no desenvolvimento da operação de restabelecimento de ordem pública', completa o oficial da PM. (Brasil 24/7: "Mesmo em teste, Detecta ajudou a coibir caos em SP", 17/09/2014)

Segundo o comando da polícia, o programa, ao combinar o uso do videomonitoramento com software moderno, permitiu que a polícia localizasse focos de conflito e mesmo acompanhasse movimento de manifestantes, a fim de enviar seu efetivo. A polícia teria sido munida, dessa forma, de uma mecanismo eficiente para que um eventual protesto e conflitos de rua não tivesse proporções ampliadas. A reintegração de posse pode, dessa forma, ser realizada com o mínimo de dano, e sem que o espaço público se tornasse zona de conflito prolongado. Ou, de outra forma, o uso do videomonitoramento em tempo real permitiu a polícia militar exercer seu controle sobre o espaço público. Maximizou sua capacidade de repressão e dissipação de manifestantes. A retirada da população do espaço público e a reafirmação desse como local de trânsito, e não como lócus da política, teria sido reafirmado.

Naquela época, o Detecta estava ainda em fase de preparação, e os comportamentos que o Detecta poderia localizar automaticamente ainda eram bastante limitados. Conforme Luiz Sergio Pires, diretor da Microsoft Advanced Technologiy Labs Brasil desde 2014, em palestra dada no evento SmartCity Business America, entre 16 e 18 de abril de 2018, já naquela época havia se afirmado que o Detecta não seria capaz de realizar acompanhamento humano integral de forma eficiente. Era necessário préselecionar a situação de risco e realizar confirmação com decisão humana. Assim, como não havia sido implementado o sistema de detecção automática, a escolha do uso do Detecta para averiguação de movimento social só pode ter sido deliberada pela mais alta gestão pública de segurança como estudo de caso para uso futuro. Isso revela (a) a intenção de uso do videomonitoramento inteligente contra os movimentos sociais; e (b) a vontade de se fazer saber que esse uso seria dado. 
Interessante notar que, um dia antes, o Jornal G1, da Globo, retratou o confronto entre sem tetos e a polícia militar sem citar o programa Detecta. Apesar de ter dado espaço para justificativas de polícia militar, e do próprio Fernando Grella, sem contestar a narrativa que os moradores teriam iniciado atos de vandalismo, o portal trouxe uma coleção de fotos retratando que o confronto resultou em caos. Citava saques de loja e policiais feridos ${ }^{37}$.

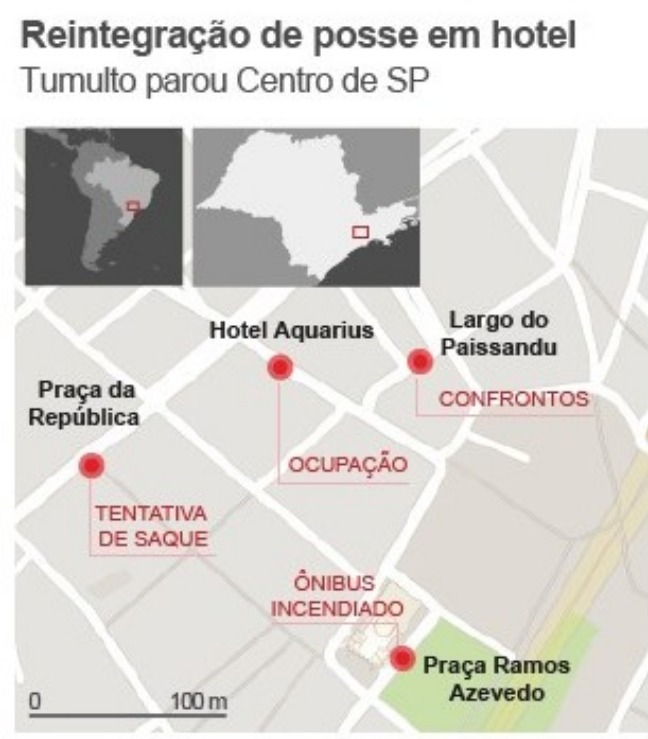

(mapa disponibilizado na notícia: "'Não houve exagero' da PM, diz secretário sobre reintegração em SP”, Jornal G1, 16/09/2014)

O mapa acima foi retirado de uma notícia do Jornal G1. O mapa traz destacado em vermelho os pontos de conflito ocorrido no dia 16 de setembro de 2014. O mapa tem como legenda: "Tumulto parou Centro de SP", e a notícia traz linguagem que descreve o conflito como uma batalha. Importante notar que essa abordagem reforça as ruas como território, onde houve conflito entre as forças de segurança (responsável pelo funcionamento normal cotidiano), e manifestantes (que atuaram como forças perturbadoras da ordem). A notícia do Jornal G1, no entanto, não falou nada sobre o uso do sistema Detecta.

Naquele momento, os grandes jornais não repercutiram a propaganda do Detecta. $\mathrm{Na}$ verdade, desde o primeiro momento foram críticos ao programa. A Folha de São Paulo, em especial, dedicou-se a criticar o Detecta, não servindo, portanto, como veículo

\footnotetext{
37 http://g1.globo.com/sao-paulo/noticia/2014/09/nao-houve-exagero-da-pm-diz-secretario-sobre-reintegracao-em-
} sp.html, visualizado pela última vez em 07/02/2018. 
de propaganda cinza. Em setembro de 2014, durante a campanha eleitoral, a candidatura de Geraldo Alckmin apresentou o Detecta como grande inovação que reduziria drasticamente o crime. Na peça publicitária da campanha, se afirmava que o Detecta seria capaz de identificar atitudes suspeitas ocorridas em espaço público, alertando a polícia para possíveis crimes, que se anteciparia ao mesmo. No dia 16 de setembro de 2014, o jornal Folha de São Paulo, denunciou que o programa ainda estava em fase de teste, e que não possuía a função de identificar atitudes suspeitas.

Se em setembro de 2014 as funções de identificação automática não eram funcionais, então a afirmação do Coronel Glauco Silva de Carvalho, em setembro daquele ano, de que o Detecta havia ajudado a coordenar o deslocamento da tropa na reintegração de posse no centro não pode ser levada ao pé da letra. $O$ uso do videomonitoramento em tempo real não é novidade, e não é o que foi prometido com o Detecta. A pressa da secretaria de segurança pública, e do então governador Geraldo Alckimin, em promover o Detecta teve o impacto negativo na operação psicológica. O uso de inverdades em peças de propaganda tem, em ambientes democráticos, limite temporal bastante curto. Quando um governo passa aos jornais informações incompletas, ou mesmo mentirosas, pode gerar receio de que haja algo mais por trás da história.

A Folha de São Paulo não aderiu à defesa do projeto Detecta. Mas não foi a única. Isso porque o projeto, lançado na propaganda antes de sua implementação, foi construído desde o princípio com irregularidades. O Tribunal de Contas do Estado investigava, já em 2014, o projeto. Criava-se o clima de que havia alguma coisa de podre no programa. A Folha de São Paulo, publicou, no dia 04 de outubro de 2014, uma reportagem intitulada: "Coronel da PM ajudou multinacional a vender Detecta para governo Alckmin":

Em maio de 2013, quando ainda estava na ativa, Deak recepcionou, em nome da Microsoft, uma comitiva do governo que viajou a Nova York em busca de opções de sistemas de inteligência para a polícia de São Paulo. Deak só entrou oficialmente para a reserva em julho do ano passado. (...) O coronel comandou o Departamento de Telemática da PM de 2009 a 2012. Nesse período, anunciou a criação de programas que prometiam funções semelhantes às hoje propostas pelo Detecta, mas que jamais chegaram às ruas. (...) Em 2012, o então secretário da Segurança, Antonio Ferreira Pinto, suspendeu compras feitas na gestão Deak -no valor de R\$300 milhões-, afastou-o do comando da área de tecnologia e transferiu-o para uma unidade na zona leste de São Paulo. (...) (a compra de R\$ 196 milhões em software da Microsoft) é alvo de análise no Tribunal de Contas do Estado por suspeita de direcionamento para uma revendedora da Microsoft. O TCE questiona ainda a dependência de um único fabricante. (Folha de São Paulo: 
"Coronel da PM ajudou multinacional a vender Detecta para governo Alckmin", 04/10/2014)

A reportagem conta como o Coronel Daek serviu de intermediário para a venda do programa Detecta da Microsoft para o governo do Estado de São Paulo, enquanto ele ainda estava na ativa. O coronel já foi suspeito de praticar irregularidades quando estava no Departamento de Telemática da polícia militar. Desde aquela época, ele prometia a entrega de projetos que realizariam o sonho de monitoramento do espaço público. No entanto, conforme reportagem da Folha, agia para realizar ganhos próprios, insinuando que tratava-se de tentativa de desvio de verba.

A reportagem, ainda, levanta a suspeita que era prática comum do Coronel Daek prometer tecnologias similares ao do Detecta, sem que essas tivessem possibilidade de aplicação real. Insinuou que o programa, na verdade, serviria como objeto de enriquecimento ilícito, e possuía vícios de nascença. Entre eles, a dependência da Microsoft, conforme apurado pelo Tribunal de Contas do Estado.

Em um prazo de dois meses, portanto, o jornal Folha de São Paulo, cuja característica é o conservadorismo, atacou o Detecta, buscando o desmistificar. Nesse momento, portou-se como adversário daquela operação psicológica, sem, no entanto, se posicionar favorável às pichações, manifestações de rua, etc. Para fins da presente pesquisa, o fato de ter havido ou não corrupção na instalação do Detecta é de pouca importância. No entanto, a postura da Folha de São Paulo, um dos principais jornais impressos do Estado de São Paulo (e do país) ajuda a entender a posição de parcela da grande mídia: na prática, portava-se como "população neutra". Durante a gestão de Fernando Grella, a secretaria de segurança pública não logrou convencer aquele importante veículo de informação de que o videomonitoramento inteligente poderia ser uma realidade. O Detecta parecia ter falhado tanto como software quanto como propaganda.

\subsection{O SISTEMA DETECTA COMO UM PROGRAMA DE INTELIGÊNCIA}

Na gestão de Alexandre de Moraes, a secretaria de segurança pública adotou uma 
nova estratégia. Em vez de insistir na promessa de que o software da Microsoft entraria em operação, mudou-se o significado do termo "sistema Detecta". De forma genérica, buscou dar a entender que o monitoramento inteligente era uma realidade, e que a função de vídeo analítico (capaz de identificar situações de risco e pessoas de interesse) estava sendo aperfeiçoado a cada dia. Essa mudança de postura significava deixar de dar ênfase na parceria com a Microsoft e na tecnologia de ponta prometida, e dar maior destaque aos resultados atribuídos ao sistema, como se os resultados comprovassem que o monitoramento inteligente já estivesse em funcionamento. Trava-se de outra mentira, mas dessa vez convenceu mais gente. Não nas grandes redações de São Paulo, mas ao menos nos pequenos jornais.

No que tocava ao Detecta, os jornais de baixo e médio impacto continuaram a atuar como agentes de propaganda cinza (que incluiu os jornais: Canal Itapevi, Portal da Afam, Jornal do Brasil, Portal do Sindicato da Habitação, Metro, Jornal Ponto Final, entre outros), enquanto os grandes jornais, como a Folha de São Paulo e o Estado (ambos jornais conservadores e marcados por linguagem hostil à população mais pobre), atuaram, durante da gestão de Alexandre de Moraes, como população aliada, mas crítica à possibilidade de sucesso da Secretaria de Segurança Pública e resistente à propaganda que não demonstrasse expressar uma realidade plausível. Das grandes redações, a única a não ter postura crítica ao Detecta foi o jornal G1, da companhia Globo.

Os trechos selecionados, a seguir, são parte de uma reportagem da Folha de São Paulo, de agosto de 2015, que relata problemas na aplicação do Detecta. Ressaltava que o programa ficou emperrado e demorava para ser entregue. Ressaltava que as operações creditadas ao Detecta na verdade viriam de outro programa:

Na eleição, em meio à escalada de roubos, a promessa do governo era que, no final de 2014, esse sistema, batizado de Detecta, estaria em funcionamento pleno, com a integração de bancos de dados da polícia e câmeras de ruas e estradas para identificar atitudes suspeitas em tempo real. (...) Na prática, porém, a gestão Alckmin diz que a tecnologia continua "em testes" - mesma informação dada em setembro, ao ser questionada sobre a inoperância do sistema exaltado na campanha como aquilo que "existe de mais avançado em segurança". (...) O Detecta, da Microsoft, custou R\$ 9,7 milhões aos cofres do Estado. Agora, porém, as primeiras operações oficialmente creditadas ao sistema virão de outro programa, que já existe há um ano. Trata-se do Projeto Radar, desenvolvido pelo Centro de Processamento de Dados da PM quase sem custos ao Estado. (...) O Radar pode identificar, por meio de câmeras, placas de carros com queixa de roubo ou furto -função prevista também para o Detecta. De maio de 2014 a 
A reportagem compara o Detecta com outro programa, que já havia sido desenvolvido pela polícia militar de São Paulo: o Projeto Radar. O Detecta era um software de videomonitoramento inteligente, enquanto o Radar era um sistema de filtro de placa. Parte das funções são semelhantes, mas possuem grau de complexidade bastante distintos. O Radar apenas identificava placas previamente inseridas em um banco de dados, avisando uma central de controle na ocasião daquela placa ser captada por algum radar de trânsito. Dessa forma, não é um mecanismo de videomonitoramento inteligente. A diferença entre a leitura automatizada de placas e o videomonitoramento inteligente, do ponto de vista do impacto na apropriação da população sobre as ruas, é que a leitura de placa incide basicamente sobre o uso de veículos. Ela não desincentiva pichação, uso do espaço para atividades de lazer não autorizadas (como batalhas de hip hop e treino de skate), ou manifestação de rua. Isso porque o sistema não detecta automaticamente essas atividades, e muitas vezes, dada a localização da captura de imagem, voltada para identificar as placas de carros, é incapaz de gerar imagens sobre o que se passa nas calçadas.

O Detecta deveria representar um salto a mais. Deveria identificar, através das imagens, pessoas e situações suspeitas. Ou seja, o software destacaria situações como alguém entrando em uma farmácia usando capacete de moto; alguém depredando patrimônio público; grandes aglomerados de população em meio de uma via; etc. Essa função, desenvolvida pela Microsoft, não havia sido inteiramente adaptada para o Brasil. O governo, no entanto, atribuiu ao Detecta parte do funcionamento do Programa Radar.

Naquele momento, a secretaria de segurança pública do Estado de São Paulo buscava passar a ideia que o Sistema Detecta era capaz de criar uma rede de vigilância e e informação que permitisse à secretaria de segurança, e às polícias, obter maior capacidade de controle sobre as cidades e as vias. Nesse sentido, o Detecta deixou de ser apenas o software "Detecta", e passou a ser um projeto ambicioso que deveria, em uma fase futura, integrar todo sistema de vigilância. A reportagem veiculada pela Folha de São Paulo distinguiu a competência da polícia militar de São Paulo, que já utilizava o 
programa Radar, com a incompetência do governo estadual, que não conseguiu desenvolver o Detecta. Essa narrativa criava dúvida à capacidade do governo de resolver o caos urbano. Veja que trata-se de caso típico da disputa pelos corações e mentes de uma operação psicológica: o governo precisa convencer a população aliada que é capaz de trazer sucesso em sua guerra (no caso, na guerra contra o "caos" urbano).

Mais de quatro meses depois, a secretaria de segurança pública apresentou em que ponto estava o Detecta. A partir de então, cada reportagem que criticava o Detecta passou a ser respondida, semanas ou meses depois, por notícias ou eventos oficiais que divulgavam ou exaltavam o Detecta. O evento foi noticiado pela associação dos oficiais da polícia militar. Os trechos selecionados, a seguir, destacam alguns dos principais elementos apresentados pela secretaria. Alguns deles são: (a) a transformação formal do Detecta em um sistema central, deixando de ser apenas o nome do software; (b) a ampliação de câmeras de videomonitoramento conectadas ao programa; (c) a absorção do Projeto Radar pelo Projeto Detecta; e (d) que os agentes já estavam sendo treinados para utilizar plenamente o programa.

\begin{abstract}
'O Detecta funciona como um grande cérebro', informou Moraes. 'Todas as informações armazenadas servirão para as polícias atuarem de forma mais eficiente no combate ao crime'. Segundo o secretário, a terceira fase de implantação foi o treinamento dos policiais e acesso ao sistema. (...) Esta tecnologia (vídeo analítico) permite detectar e prevenir potenciais ameaças de crime ou impedir a ação criminosa e vai desempenhar um papel importante para melhorar a segurança pública dos cidadãos. (...) Atualmente, o Detecta tem 1.172 câmeras, sendo 531 de videomonitoramento público e 641 OCRs, com sensores eletrônicos integrados ao seu banco de dados, com capacidade de emitirem alertas automáticos a partir da leitura das placas de veículos e permitir análises de situações de práticas de crimes com o cruzamento de outros dados criminais. (Portal da associação dos oficiais da polícia militar: "Secretário da Segurança Pública apresenta usos do Detecta", 23/09/2015)
\end{abstract}

Dessa forma, em setembro de 2015, estava anunciado que São Paulo estava em vias de possuir uma rede única de monitoramento a distância sobre seus cidadãos. Os projetos estavam integrados. Os agentes, munidos de equipamento conectado com um centro de comunicação, poderiam, em tese, ser direcionados para combater o crime. 0 Portal Maxpress, repercutindo um informe da Secretaria de Segurança Pública de São Paulo, do dia 18 de setembro de 2015, abriu uma reportagem, do dia 21 do mesmo mês, com a seguinte frase de Alexandre de Moraes: "O Detecta funciona como um grande 
cérebro". A reportagem ainda trouxe a explicação dada pelo então secretário da SSP: "Todas as informações armazenadas servirão para as polícias atuarem de forma mais eficiente no combate ao crime".

Mas essa utopia da segurança ainda não estava plenamente instalada. Contra ela pesava o grande número e ocorrências criminais em São Paulo; e o baixo efetivo policial, inviabilizando o controle espacial de facto. Ainda, o software do Detecta tinha dificuldade de identificar tipos distintos de situação de risco. Por último, algumas situações exigiam mobilização policial em volumo maior, inviabilizando uma resposta automática. Por exemplo, uma manifestação que parasse uma via através de queima de pneus podia não ser respondida de imediato por (i) dificuldade de detecção do ocorrido; e (ii) pela necessidade de tomada de decisão hierarquicamente confirmada para lidar com esse tipo de problema.

O que não se dizia é que, na prática, do Detecta a única coisa que funcionava era o sistema Radar. Apesar de possuir 531 câmeras de videomonitoramento público, a análise automática se resumia à leitura de placas. O secretário de segurança do Estado de São Paulo afirmou que o Detecta fornecia um "cérebro" ao sistema de policiamento de São Paulo. Dava a entender que, com o novo sistema, policiais receberiam alertas em suas viaturas e poderiam agir imediatamente para prevenir o crime. A imagem induz ao público acreditar que (a) os policiais poderiam agir quase de forma independente, assim que recebessem o alerta; e (b) que havia uma gama de "práticas de crime" que podiam ser analisadas e gerariam alertas à polícia. Tratava-se de um esforço de afirmar que estava em funcionamento aquilo que, havia apenas quatro meses a Folha de São Paulo afirmava que não existia: o chamado monitoramento inteligente por vídeo analítico.

Apenas um mês depois, a terceira fase do Detecta (de unificação do Detecta com o Radar) foi finalizada. Em um espaço de um ano e seis meses, portanto, o Detecta teria concluído 3 fases, sem que jamais tivesse se cumprido o prometido no momento de aquisição do software da Microsoft. Mas a quarta fase, iniciada em outubro de 2015, dessa vez descreveu um uso distinto do Detecta:

O secretário da Segurança Pública, Alexandre de Moraes, lançou a implantação da $4^{a}$ fase do Detecta com a instalação de uma "cinturão eletrônico" de videomonitoramento que cobrirá todo o litoral do Estado, chegando ao Alto Tietê. 
Esta etapa do Detecta é fruto da conexão de 480 câmeras e radares OCRs, além de mais 2.181 câmeras de monitoramento em municípios e estradas da região ao sistema. (...)

O sistema receberá alertas em tempo real sobre roubos e furtos de veículos e outras situações suspeitas ocorridas em vias de todo o litoral paulista e estradas que dão acesso às regiões, além de abranger também o Vale do Paraíba e Alto Tietê. (SSP: "Sistema de prevenção e investigação", 05/10/2015)

O informe da secretaria de segurança pública, repercutida pelos jornais Portal da AFAM, Tribuna de Indaiá, Revista Exame, entre outros, listava as "outras situações suspeitas": veículo furtado, veículo roubado, veículo envolvido em ação criminosa, proprietário de veículo com mandado de prisão e proprietário de veículo com registro de desaparecimento. O que o informe descrevia como "cinturão eletrônico" era um sistema de cerco de videomonitoramento nas estradas do litoral do Estado de São Paulo. A mesma tecnologia já era aplicada em vias como a Marginal Tietê, na cidade de São Paulo. Embora use eufemismos, o informe deixava claro o que o Sistema Detecta fazia: era apenas a integração de um sistema de leitura de placas (via radares OCRs e câmeras de videomonitoramento) para localizar veículos que tenham sido previamente listados na base de dados.

Embora a própria secretaria, em seus informes oficiais, não identificasse nenhuma tecnologia capaz de diminuir a violência nas cidades, não cessou sua propaganda onde afirmava que o Detecta auxiliaria no "combate ao crime" nas cidades. Continuava a vender a utopia do sistema de segurança onisciente. Idealmente, essa onisciência levaria até a onipresença. Essa utopia seria o estabelecimento do espaço público completamente asséptico, protegido e garantido.

A sacralidade da propriedade privada e da integridade da propriedade pública, é uma doutrina que guia parte das políticas públicas. A propaganda em torno da instalação de câmeras de videomonitoramento não é diferente. As câmeras são apresentadas como instrumento para defender dado tipo de cidadão, o cidadão consumidor, em detrimento de outros, os cidadãos suspeitos. O setor privado é até mesmo convidado para fazer parte do sistema de vigilância e perseguição àqueles que desrespeitam as normas de convivência.

Os trechos a seguir fazem parte de uma reportagem do jornal $\mathrm{G} 1^{38}$, do grupo

38 O Jornal G1 foi o único jornal de grande impacto a repercutir de forma acrítica os informes oficiais sobre o Detecta. 
Globo, que relata a intenção do governo do estado de São Paulo em integrar as câmeras de segurança privadas (em especial a de condomínios) ao sistema de monitoramento do estado. Uma vez integrados, passariam a fazer parte do sistema Detecta. Esse desejo já começava a se tornar realidade através do acordo com o Sindicato de Habitação de São Paulo.

O governo do estado de São Paulo fez um acordo com o Sindicato da Habitação de São Paulo (Secovi) para conseguir interligar as câmeras de segurança dos prédios ao Sistema Detecta da Polícia Militar, informou o SPTV desta segundafeira (12). (...)

Na última semana foi publicado no Diário Oficial o termo de cooperação entre o Secovi e a Secretaria da Segurança Pública (SSP) para integrar as câmeras privadas ao Sistema Detecta. Com o acesso às imagens, a polícia pode deslocar uma viatura ao local do crime no momento em que ele ocorre, aumentando o alcance da vigilância. (Jornal G1: "Governo de SP quer integrar câmeras de condomínios à Polícia Militar”, 12/07/2016)

Na prática, afirmou-se que os condomínios passariam a fazer parte de uma malha de segurança e vigilância da polícia. Quando o detecta estivesse em pleno funcionamento, qualquer assalto, depredação, ou mesmo pichação em muros poderiam ser detectadas em tempo real. Em última instância, os condomínios aceitaram fazer parte até da política de repressão a vendedores ambulantes que possam vir a ser perseguidos pelo sistema. ${ }^{39}$

Até possíveis festas feitas pelos moradores dos condomínios, se acabassem ocupando parte das vias públicas em frente aos mesmos, poderiam ser alvo de monitoramento. A aceitação por parte do sindicato de habitação de São Paulo em participar do programa revela um aspecto da sociedade de controle: sua existência e ampliação depende da aceitação da população. O que pode fazer estranhar é que a população aceita, e participa ativamente da mesma. O motivo para isso são vários. Alguns são de cunho psicológico (crença que só o outro será vigiado e punido, dividindo o mundo entre os escolhidos e o resto); outras de caráter imediatista (abandono de liberdade por medo da violência); mas um nos interessa mais: o ideológico.

A associação de habitação de São Paulo aparentemente concordava com a

39 Uma das propostas defendidas pelo candidato eleito para prefeitura de São Paulo, em 2016, era a de realizar uma guerra contra os camelôs ilegais na cidade, além da guerra aos pichadores. 
concepção que o espaço público é um local feito para o trânsito e para o consumo. Toda atividade no espaço público, para ela, deve ser normatizado e vigiado. Os problemas de segurança são, nessa concepção, fruto do desrespeito a norma. Ignora, ou escolhe ignorar, o papel da leniência da polícia com o crime organizado. Como, para eles, o uso do espaço público está voltado a uma concepção de sociabilidade pelo consumo, mesmo eventual "endurecimento" da vigilância policial, com todos seus vícios e arbitrariedade, não seria problema.

O que se observa é que, entre 2015 e 2016, a propaganda da secretaria de segurança pública do Estado de São Paulo colheu frutos. O Sistema Detecta, cuja aplicação verificada era apenas o de monitoramento dos veículos que transitavam nas vias vigiadas, ampliou suas parcerias. Os parceiros acreditavam estar fazendo parte de um sistema de inteligência capaz de diminuir as perturbações no uso normatizado do espaço público. Havia claro hiato entre aquilo que os parceiros acreditavam apoiar e aquilo que de fato estava sendo implementado.

O recém-parceiro do Detecta, o Sindicato de Habitação de São Paulo, noticiou, no dia 08/08/2016, mais um passo na ampliação do Detecta: a integração de mais 900 radares da cidade de São Paulo ao sistema. Essa integração foi, inclusive, um dos programas ressaltados pelo prefeito Haddad na campanha eleitoral, no ano. Com ela, nas palavras de Mágino Alves, o então secretário de segurança pública do Estado de São Paulo, São Paulo estava munida de uma cerca eletrônica de segurança:

Um convênio assinado entre a Secretaria de Segurança Pública do Estado de São Paulo e a Prefeitura da capital paulista vai integrar os mais de 900 radares da cidade ao sistema de segurança Detecta. 'Com isso, faremos uma verdadeira cerca eletrônica de segurança', afirmou Mágino Alves, secretário de Segurança Pública, em reunião-almoço na sede do Secovi-SP nesta segunda-feira, 8/8. Segundo ele, com esse convênio, a polícia terá condições de, em pouco tempo depois de iniciada uma ocorrência, estruturar uma operação para combater a atuação dos criminosos. Como exemplo, disse que, se alguém sofrer um sequestro-relâmpago e uma pessoa testemunhar e ligar para o 190, fornecendo informações básicas do carro que participou da ocorrência (como cor, tipo e trechos da placa), bastará esse veículo passar por um radar para que, em quatro segundos, o Detecta seja acionado e a polícia comece a agir. 'O mesmo vale para roubo de carga e inúmeros outros crimes', sustentou. (Portal do Sindicato de Habitação de São Paulo: "Detecta vai integrar radares da Prefeitura para aumentar segurança na Capital", 08/08/2016) 
A palavra cerca foi bem escolhida. Reflete bem a intenção do programa: estabelecer um cerco eletrônico sobre o espaço público do Estado, e, portanto, da cidade de São Paulo. Embora a principal justificativa seja o combate ao crime, induz-se à percepção que sistema seria utilizado para identificar toda forma de apropriação não normatizada do espaço público. O cerco eletrônico é o objetivo do Detecta. Esse cerco tem suas consequências no que toca a disputa sobre o espaço público. Ele é uma arma a mais na reafirmação da organização do espaço desde um conjunto normatizado, favorável a uma concepção consumista e formalista da coisa pública.

No entanto, Mágino Alves não afirmou que o Detecta faria aquilo que havia sido prometido nos anos anteriores. Ao contrário, descreveu como funcionaria o convênio. Os radares da prefeitura seriam utilizados para localizar placas de carros identificados como envolvidos em ocorrência criminal. Através do georreferenciamento da placa captada pelos radares, depois de cruzada pelo banco de dados, seria possível identificar a região onde o carro esteve, com apenas quatro segundos de atraso. Note que não se afirmou que o Sistema seria capaz de prever trajetória do carro, ou identificar situação de risco. A afirmação de que os radares integrariam o Detecta para aumentar a segurança na capital, feita pelo sindicato de habitação, foi uma propaganda cinza tendo como base o imaginário criado nos anos anteriores.

Apenas cinco dias depois do sindicato de habitação noticiar o convênio entre Estado e Prefeitura de São Paulo, o jornal O Estado de São Paulo repercutiu um relatório do Tribunal de Contas do Estado, onde denunciou que o Sistema Detecta não cumpria o que havia sido prometido no programa Detecta:

Um relatório de fiscalização do Tribunal de Contas do Estado (TCE), concluído em junho, afirma que o programa Detecta, sistema eletrônico criado para permitir o uso de imagens de câmeras pela Secretaria Estadual da Segurança Pública (SSP), ainda não é capaz de analisar crimes filmados. Conforme os técnicos, a ferramenta 'vídeo analítico' não está disponível, apesar de o governo informar que esse monitoramento já é uma realidade. A secretaria paulista diz que os problemas apontados pelo TCE estão resolvidos ou passam por alteração. (...) Segundo o TCE, apenas 17 câmeras de vigilância em todo o Estado têm a função de análise de imagens ativas - e nenhuma delas é capaz de identificar um homem com capacete em um comércio. $O$ que o sistema faz é relatar ações mais simples: pedestre na via, moto parada entre carros parados e automóvel parado no acostamento em via expressa. (...) A Secretaria da Segurança Pública (SSP) informou (...) que o Detecta é um 'big data' que integra bancos de dados das polícias paulistas e tem câmeras integradas ao sistema. (Jornal O Estado de São Paulo: "Após 2 anos, sistema Detecta da polícia não identifica crimes, diz TCE", 
O sonho de uma cidade policiada em tempo real por um sistema de câmeras inteligentes, não era uma realidade. Na verdade, o software utilizado, o Detecta, era incompatível com a tecnologia utilizada em São Paulo, conforme a análise do Tribunal de Constas do Estado. Isso fez que a principal função do software (realizar análise de vídeo para automaticamente identificar situações de risco) não estivesse funcionando ainda.

O que a notícia relatava era claramente que Sistema Detecta não era o Software Detecta. Era, em termos de projeto, outra coisa. A própria Secretaria de Segurança Pública reconhece: o Sistema Detecta é um 'big data'. Ou seja, é a capacidade das câmeras e radares enviarem metadados para um sistema, que por sua vez cruza as informações coletadas, e as georreferências.

Esse sistema é muito pouco eficaz para prevenção de crimes. Ao contrário, se presta para repressão ao crime após o acontecimento. Ainda, funciona para caça de "persons of interest" (pessoas visadas pela polícia). A sua melhor aplicação, como prevenção, era ajudar a pegar "os suspeitos de sempre", uma vez que podia ser usado para identificar veículos sob propriedade de suspeitos de envolvimento com crime, ou que tivessem passagem na polícia. Assim, placas de carro de propriedade de pessoas investigadas por tráfico de droga podia ser, por exemplo, localizada e interceptada. Isso em nada tinha a ver com a promessa de identificação do crime em tempo real (ou até antes) de que ele acontecesse. A resposta da secretaria de segurança pública, portanto, era que o Detecta não era um único instrumento. Era um sistema de inteligência, que poderia ser utilizado de distintas formas para munir a polícia de uma capacidade superior de investigação e organização para o combate ao crime.

\subsection{UMA PROPAGANDA DE NARRATIVA INVEROSSÍMIL}

O principal problema do uso do Detecta como parte de uma operação psicológica, ou mesmo como uma propaganda em um contexto de guerra total pelo espaço público, é que ela falhava em um dos seus pré-requisitos básicos. O Sistema Detecta apelava ao símbolo de uma polícia altamente capacitada e munida de tecnologia de ponta. Buscava 
ativar a esperança de um mundo sem perturbações na ordem, pois uma vigilância suprema e inteligente seria capaz de ver o crime em tempo real, e até prever sua ocorrência antes do tempo. Tentou fazer os paulistas acreditarem que viveríamos, em breve, em cenas de filmes ou seriados de ficção científica onde existem olhos que tudo veem.

A imagem tem um problema. Ela não faz parte do imaginário da sociedade brasileira. O signo de uma polícia bem equipada e bem preparada contrasta com a realidade brasileira. Aqui, o símbolo é justamente o oposto. A população vê a polícia brasileira como desprovida dos meios necessários para garantir a ordem. Para uns, simpáticos às causas populares, isso é fruto do racismo e arcaísmo da instituição da polícia militar. Para outros, simpáticos ao esforço de instituição da ordem pública, entendendo a ordem como a ausência de conflito ou de contraditório no espaço público, é fruto da incompetência e corrupção do próprio Estado. A ideia de que uma secretaria de segurança pública lançaria um programa, ou um sistema, capaz de mudar completamente a realidade social era simplesmente inverossímil.

Ainda assim, em 2016, a prefeitura de São Paulo assinou o convênio com o Estado para fazer parte do Detecta. Passou, naquele momento, a ser parte interessada na continuidade da propaganda de que o videomonitoramento inteligente era uma realidade. Em primeiro momento, os louros do convênio foram colhidos pelo governo do Estado. Mais uma vez o Detecta foi apresentado pela prefeitura como sendo um programa mais complexo do que um monitorador de veículos:

Muito mais que um sistema de monitoramento inteligente, o sistema Detecta é o maior Big Data (conjunto de informações armazenadas) da América Latina, que integra bancos de dados das polícias paulistas, como os registros de ocorrências, Fotocrim (banco de dados de criminosos com arquivo fotográfico), cadastro de pessoas procuradas e desaparecidas, dados do Detran (Departamento Estadual de Trânsito), registro de veículos furtados, roubados e clonados. (Portal do Governo: "Sistema Detecta ganha 97 novas câmeras de monitoramento", 18/10/2016.)

No informe do governo, além de afirmar que o Detecta era um big data, Geraldo Alckimin afirmou que o sistema possuía um "sistema de vídeo analítico de um software inteligente", que ajudava a resolver diversos tipos de caso, inclusive de estelionatários. 
Afirmava que era instrumento importante para a segurança pública. Constantemente, sempre que acusado, o governo do Estado afirmava que o vídeo analítico e o monitoramento inteligente era sim uma realidade, e que estava sendo constantemente aprimorado. No entanto, dois anos após sua implementação, o Detecta ainda cumpria apenas o que o projeto Radar já fazia: identificar veículos.

A grande diferença é que agora as placas localizadas estavam indexadas em um banco de dados, onde constava a lista de ocorrências relevantes, e fotos de eventuais donos ou suspeitos ligados ao veículo em questão. Evidentemente, a ferramenta era sim útil à polícia para combater furto de carros e localizar foragidos ou suspeitos previamente selecionados. A promessa de videomonitoramento inteligente, apesar de sempre constar nas propagandas oficiais do governo e da secretaria de segurança pública, foi oficialmente abandonada, conforme uma notícia do jornal do Estado de São Paulo, que citava um relatório do Tribunal de Contas do Estado, de 2017:

\begin{abstract}
Um relatório de fiscalização do órgão publicado nesta sexta-feira, 28, no Diário Oficial afirma que a "solução de vídeo analítico" prevista no Detecta - que seria capaz de captar condutas suspeitas na rua por meio de câmeras de segurança e monitoramento, identificar a localização e acionar automaticamente a Polícia Militar - foi excluída do contrato firmado entre a Secretaria da Segurança Pública e a Companhia de Processamento de Dados do Estado (Prodesp), responsável por adotar o sistema. (O Estado de São Paulo: "Sistema de vídeo contra crime ainda é falho, diz TCE", 29/04/2017)
\end{abstract}

Conforme o TCE, o desenvolvimento de um software para um monitoramento capaz de identificar atitudes suspeitas foi oficialmente abandonado. O Jornal O Estado de São Paulo, na ocasião da divulgação do relatório do TCE, contrariou a narrativa do governo do Estado, utilizando relatórios oficiais. Mais uma vez, o problema de pautar uma peça de operação psicológica e mentiras, em uma democracia, é que os órgãos de controle e a atividade de jornalistas põe em evidência a natureza da peça. Ou seja, aquela altura, era evidente que o Detecta jamais iria cumprir o que havia prometido. Nenhum órgão sério acreditava mais nas promessas. Os próprios órgãos de controle interno do Estado denunciavam a falácia do programa. Ainda assim, os formuladores e responsáveis pelo Detecta tentavam vender o peixe que não haviam percado.

Em 2017, já não fazia mais qualquer sentido em falar de vídeo analítico no Sistema 
Detecta. O contrato da Prodesp não continha mais esse item. Portanto, afirmar que o videomonitoramento inteligente estava sim em funcionamento não se explicava mais do ponto de vista da defesa de uma política que se desejava implementar. Na verdade, só se justificava, agora, como pura peça publicitária, sem ter como base sequer a promessa de sua aplicação em um futuro próximo. A afirmação que o videomonitoramento inteligente iria mudar a segurança pública (e portanto o espaço público) de São Paulo era pura obra de ficção. Transformava-se de uma propaganda cinza em uma propaganda negra. Ou, em uma linguagem mais recente, se tornou apenas um "fakenews" 40.

Apenas três dias depois da notícia do jornal O Estado de São Paulo, o governo do Estado voltou a defender seu programa, descrevendo-o de forma nebulosa, e dando a entender (dessa vez sem o afirmar) que o Detecta possuía um monitoramento inteligente. Lançou uma nota intitulada "Detecta monitora o Estado de SP com mais de três mil câmeras de vídeo", onde afirmava:

\begin{abstract}
Também são utilizadas nas operações policiais, as imagens de câmeras particulares, que são analisadas e triadas pelos funcionários das empresas. As imagens relacionadas com ocorrências policiais são enviadas para o banco de dados na forma de alertas. Elas são gravadas e armazenadas onde foram registradas e podem ser requisitadas em caso de ação policial ou militar.

Um balanço dos resultados do monitoramento no Estado de São Paulo indica que, no período de 2014 a 19 de abril de 2017, as imagens captadas contribuíram para a prisão de 4.731 pessoas em flagrante delito; interceptação de 3.320 veículos, apreensão de 276 armas de fogo e leitura de 20 bilhões de placas de automóveis. (Portal do Governo: "Detecta monitora o Estado de SP com mais de três mil câmeras de vídeo", 02/05/2017.)
\end{abstract}

$\mathrm{Na}$ nota, ainda, afirmava que entre 2014 e 2017, as imagens captadas pelo Sistema Detecta contribuíram para prisão de 4731 pessoas em flagrante, com interceptação de 3320 veículos (o que significa a prisão de menos de uma pessoa e meia por veículo apreendido). Mais uma vez ressaltava o uso de largo banco de dado aliado ao georreferenciamento das imagens obtidas como instrumento importante.

Como o trecho ressaltado deixa claro, as imagens que não dizem respeito diretamente à placa de carros só são úteis após analisada por um humano. Ainda, funcionam principalmente para levantamento posterior sobre os crimes ocorridos. Mas, a

40 Notícia falsa produzida com o intuito de esconder a verdade e causar comoção no público-alvo. 
nota gera confusão ao utilizar o termo "operação policial", quando se refere à investigação policial. A nota, em momento algum, fala de vídeo analítico, mas dá a entender que ele existe. Trata-se de uma peça publicitária bolada com cautela, vendendo um produto que não existe sem citar a existência do produto. Essa nota da SSP foi repercutida por jornais como CidadeOn São Carlos, Diário da Região São José do Rio Preto, Portal Nacional dos Delegados, Siga Mais, entre outros. O esforço de defender o Sistema Detecta sem citar a existência de sistema de vídeo analítico poderia significar o abandono da narrativa que já se mostrava esgotada.

Mas não foi isso que aconteceu. Na verdade, a propaganda apenas mudou de público alvo. Em maio de 2017, a secretaria de segurança pública lançou uma cartilha de adesão ao sistema detecta, entregue para as prefeituras do Estado de São Paulo. É de se esperar que um programa do Estado que visa atrair prefeituras seja marcado pela clareza sobre o que se pretende. Afinal, a cartilha não foi distribuída ao público em geral. Dessa forma, não tem sentido tratá-la como uma peça de propaganda voltada ao inimigo ou ao público neutro. Mas, visando atrair participantes para o Sistema Detecta, novamente voltou a afirmar que o mesmo usava a tecnologia de vídeo analítico:

\footnotetext{
Qual é a arquitetura do Sistema Detecta da SSP?

Uma Solução de Software, com interface Web, composta por uma infraestrutura de servidores que realizam funções inteligentes de correlacionamento de diversos tipos de eventos de interesse de segurança pública com as informações das bases de dados integradas à solução: Veículos, Pessoas (civil e criminal), Atendimento 190 , etc. Os dados dos eventos são encaminhados à solução por intermédio dos seguintes tipos de equipamentos, provindos de sistemas públicos ou privados: LAP - Leitores Automáticos de Placas de veículos, Sistemas de Videomonitoramento, Ferramentas de Vídeo Analíticos, Sensores, entre outros. (SSP: "CARTILHA DE ADESÃO AO SISTEMA DETECTA - V3.0", Maio 2017)
}

A descrição nebulosa fala de "correlacionamento de diversos tipos de eventos" e de "ferramentas de vídeo analíticos". A cartilha induz aos governos das prefeituras a acreditarem que o Sistema Detecta é capaz, portanto, de realizar correlação de eventos de interesse de segurança pública com um banco de dados. Ou seja, usando um Big Data seria capaz de identificar pessoas de interesse e situações de risco. Afinal, o termo correlação pressupõe probabilidade. Portanto, o que se diz é que o sistema identifica possíveis situações de risco. O modelo de convênio, que é anexo I da cartilha, traz a seguinte afirmação: "O presente convênio tem por objeto o desenvolvimento de ações 
conjuntas entre Estado e Município voltadas à prevenção do crime e da violência". Mais uma vez, induz-se à ideia que haja um monitoramento inteligente.

No anexo V, quando são dadas as instruções para instalação de câmeras para o envio de imagem para que ocorra o "vídeo analítico", no entanto, fica claro que o mesmo não é voltado para identificação de situações de risco. Entre as instruções, é afirmado que a câmera deve estar posicionada acima ou dentro da via monitorada, de forma que consiga captar as placas de carros. Ou seja, o software rodado na verdade identifica a placa de carro ${ }^{41}$.

A insistência em fingir que o Estado de São Paulo possui uma tecnologia que não o tem, evidentemente, traz suspeitas. Apesar de ter cessado de afirmar expressamente em seus comunicados que era o Sistema Detecta possuía análise de situações suspeitas, pela propaganda anteriormente realizada, e pelos termos de seus convênios, parte dos jornais continuaram a tratar como se o Detecta fosse um sistema de videomonitoramento inteligente. O resultado foi que as críticas ao programa inverossímil continuaram. O portal de notícias da Uol trouxe o seguinte balanço sobre o Detecta, em dezembro de 2017:

Apenas duas polícias do mundo utilizam um sistema de monitoramento da criminalidade que é capaz de identificar uma atitude suspeita e alertar policiais: Nova York e São Paulo. Nos Estados Unidos, a tecnologia foi implantada em 2007. No Brasil, no segundo semestre de 2014, em plena campanha eleitoral. O sistema, denominado Detecta, foi a principal bandeira de segurança pública do governador Geraldo Alckmin (PSDB) para sua reeleição em 2014.(...)

Apesar disso, os índices da criminalidade não apresentaram queda no Estado, que, aliás, teve aumento na média de roubos para mais de 1.000 a cada dia. No segundo semestre de 2014, quando a tecnologia começou a ser implantada, a média de roubos no Estado foi de 1.087 ao dia. Todo o sistema foi entregue por completo no segundo semestre de 2015. Com o Detecta em ação no primeiro ano, o índice de roubos baixou para 1.057 por dia. No entanto, em 2016, voltou a subir: diariamente, a média foi para 1.099 roubos. Entre janeiro e outubro de 2017, foram registrados em delegacias do Estado 315.323 roubos --média de 1.040 por dia. (UOL: "Após implementação de principal bandeira de Alckmin para segurança, média de roubos sobe", 12/12/2017)

A reportagem é bastante clara. Trata o Detecta como um sistema de videomonitoramento inteligente, e aponta que as duas únicas polícias do mundo a usar uma ferramenta tão avançada como essa são a de Nova lorque e a de São Paulo. A

41 A identificação de placa de carro se faz pela tecnologia OCR (Optical Character Recognition), que permite a transformação de uma imagem que contenha caracteres em caracteres de um programa de computador. Isso permite, entre outras coisas, que uma série de letras seja cruzada com um banco de dados. A tecnologia de vídeo analítico, por outra parte, é a capacidade de identificação de situações pré determinadas. 
aproximação ainda que retórica entre São Paulo e uma cidade norte-americana permite mobilizar uma percepção de modernização anterior a qualquer eficiência concreta. Em momento algum o portal de notícias levantou suspeitas que o sistema não existisse. No entanto, critica a eficiência do mesmo. A promessa era que o videomonitoramento inteligente aumentaria a segurança pública. No entanto, os índices de criminalidade demonstraram piora, conforme a reportagem.

O que se percebe é que o Detecta falhou em três aspectos. O primeiro, falhou como programa de videomonitoramento inteligente, que jamais foi implantado. Em segundo, falhou como solução de inteligência para a afirmação da ordem no espaço público. Em terceiro lugar, falhou como propaganda capaz de aglutinar aliados e convencer a população da capacidade do Estado de diminuir a insegurança urbana, garantindo o uso normativo do espaço público. Essa batalha psicológica realizada pela secretaria de segurança pública foi perdida, e sequer logrou convencer seus próprios aliados potenciais. No entanto, isso não quer dizer que o anseio pela assepsia do espaço haja sido derrotado, nem que o videomonitoramento (tradicional) haja sido descartado como ferramenta tanto de combate físico pelo espaço, como de combate semiótico pelo mesmo.

Em julho de 2017, a prefeitura de São Paulo lançou o projeto City Câmeras, que tinha como principal resultado o desenvolvimento de um site onde câmeras públicas de videomonitoramento podiam ser acessadas. No site, usuários do setor privado podiam se cadastrar incluir suas próprias câmeras do sistema. Tanto a política como o próprio usuário passavam a ter acesso às imagens alimentadas no sítio de internet:

A Prefeitura lançou, nesta terça-feira (11), o site do City Câmeras, com orientações à população e a empresas sobre como participar do programa. $O$ site (www.citycameras.prefeitura.sp.gov.br) será uma plataforma de monitoramento de segurança da cidade, reunindo imagens de todas as câmeras conectadas ao sistema e que poderão ser acessadas diretamente pelos distritos policiais, batalhões da Polícia Militar e Guarda Civil Metropolitana (GCM), garantindo mais agilidade nas ações de prevenção e combate ao crime e contribuindo nas investigações. O sistema também é integrado ao Detecta, da Secretaria Estadual da Segurança Pública.(Secretaria Especial de Comunicação da Prefeitura de São Paulo: "Prefeitura de São Paulo lança site do programa City Câmeras", 11/07/2017)

O informe dado pela própria prefeitura, portanto, identifica que o sistema visa a 
integração do videomonitoramento privado e público. O sistema integrava o Detecta. No entanto, diferentemente do Detecta, o City Câmeras era uma ferramenta que declaradamente servia à investigação de crimes já ocorridos. Entre os crimes que a prefeitura, na época, buscava investigar, estavam principalmente os crimes contra o patrimônio. Em especial, a pichação.

O fato do Detecta ter falhado como ferramenta de propaganda, não significa que o videomonitoramento não tenha sido usado como ferramenta da guerra psicológica. $\mathrm{Na}$ verdade, no que toca a disputa semiótica para demonização da apropriação espontânea do espaço público, mesmo os jornais que não se alinham automaticamente à secretaria de segurança pública se tornam agentes de propaganda cinza. E na propaganda cinza, o videomonitoramento, como instrumento de identificação post factum, é tratado como capaz de identificar e levar os "delinquentes" à punição. Nesse sentido, o city camêra, mesmo sendo objeto de menor publicidade, apelou a um conjunto de imagens sentimentais mais palpáveis para aqueles que participam da utopia do espaço asséptico.

\subsection{A PROPAGANDA CINZA CONTRA A APROPRIAÇÃO ESPONTÂNEA DO} ESPAÇO

O projeto city camera foi apresentado como um programa que fazia exatamente aquilo que já fazia parte da cultura simbólica na mídia brasileira: que o videomonitoramente pode ser utilizado como ferramenta para identificar e punir "delinquentes" e "vândalos" que depredassem, ou perturbassem, o espaço público. Mesmo durante o período em que o governo do estado se esforçou para fazer propaganda do Sistema Detecta, a mesma mídia que demonstrou resistência à ideia de um videomonitoramento inteligente, demonizava certos tipos de apropriações culturais do espaço, e pregava o uso de câmeras de vídeos contra os envolvidos. Em especial, se participou da criminalização de pichadores. Ainda, associou os pichadores com segmentos da cultura hip hop, e com movimentos políticos radicais.

Esqueitistas, black bloques, pichadores, rapperes, etc. são encarados com suspeita, sempre que suas atividades perturbam o funcionamento "normal" da sociedade. No período entre 2014 e 2017, alguns jornais reiteradamente atacaram esses grupos. Em 
algumas reportagens, ressaltaram a importância do videomonitoramento para combater e punir as atividades consideradas vandalismo, pela linha editorial dos distintos jornais ${ }^{42}$. Por exemplo, em 2014, o jornal O Estado de São Paulo veiculou a seguinte notícia:

Inaugurada no sábado, a pista de skate da Praça Roosevelt, na região central de São Paulo, foi pichada no dia seguinte. Para combater novas investidas dos pichadores, a Skatenuts, empresa responsável pela manutenção do equipamento, já pretende pintar um grafite no local. Quatro artistas devem apresentar modelos de desenho nesta sexta.

Apenas cobrir a pichação com tinta seria insuficiente, segundo a gerente de Marketing da Skatenuts, Mariana Varenuzzi. "Se pintamos em um dia, no outro já está pichado de novo, mas acredito que os skatistas vão respeitar o grafite, então será uma boa solução", afirmou. (...)

Na parceria também está prevista a instalação de câmeras capazes de monitorar 18 pontos da praça. Além disso, duas câmeras ficarão na pista de skate. "Uma delas terá o acesso liberado para a Guarda Civil Metropolitana e para a Polícia Militar, já a outra será de uso do skatista, que poderá filmar suas manobras", disse Mariana. As câmeras devem ser instaladas até a metade de 2015. (O Estado de São Paulo: "Pista de skate da Praça Roosevelt é pichada $24 \mathrm{~h}$ depois de inauguração", 04/12/2014)

Os trechos retirados da reportagem demonstram aspectos relevantes sobre o discurso construído acerca da pichação. A notícia relata o caso da pichação na pista de skate na Praça Roosevelt, possuindo diversas passagens onde o desprezo com a pichação é visível. Os trechos escolhidos, no entanto, revelam que a própria empresa que administrava a pista, especializada em skatismo, possui uma depreciativa dos próprios esqueitistas. A representante de marketing da empresa, que o jornal O Estado deu voz, deixa claro que acredita que a pichação (algo negativo) era feita pelos próprios esqueitistas (coisa que ninguém tinha prova). Ainda, afirma que se fosse feito no lugar um grafiti (que é uma forma de pichação), os esqueitistas respeitariam. De qualquer forma, a solução dada pela empresa era política: utilizar artistas de rua para fazer uma pichação ${ }^{43}$ que fosse mais agradável ao público em geral, na esperança que artistas independentes não usassem o espaço para se expressar de forma desorganizada.

A reportagem ainda apresenta outra solução prevista, que já constava no contrato

42 Em especial, destaca-se que os jornais: Folha de São Paulo, o Estado de São Paulo, Jornal G1 (melhor seria falar da linha editorial da Globo), Band News, entre outros.

43 Importante sempre ressaltar que a divisão entre pichação e grafiti é de conteúdo, e tem claro caráter político. Em algumas línguas, como o inglês, não se utiliza duas palavras distintas para aquilo que apenas significa uma mudança de conteúdo: picho (palavras, cores, ou desenhos rudimentares pintados em uma parede) e grafite (desenho ou pintura esteticamente agradáveis feitos em uma parede). 
firmado entre a prefeitura de São Paulo e a empresa Skatenuts: instalação de câmeras de segurança, sendo algumas delas de uso da GCM e da Polícia Militar. Assim, parte da solução para pichação em uma praça onde há uma pista de skates era a de munir a polícia de ferramentas para identificar pichadores. Portanto, era criminalizar a arte.

Na mesma reportagem, foi dada voz a alguns moradores, e à prefeitura de São Paulo. Para prefeitura, toda pichação atrapalhava o convívio pacífico no espaço público. Mas, já que era inevitável que houvesse, uma vez que o esqueite está relacionado ao picho, então a prefeitura ajudaria a escolher algum artista de rua que frequentasse a praça para fazer um grafiti. Moradores da região, no entanto, apontavam, segundo o jornal, que a pista de esqueite como um todo atrapalhava o espaço, pois os esqueitistas não ficavam só na pista, e ocupavam outros locais da praça pública. A reportagem, além de revelar o grau de preconceito existente contra parte da cultura hip hop, demonstra também a visão hegemônica do que deve ser um espaço público. Tanto para prefeitura como para os entrevistados selecionados para reportagem ressaltaram a necessidade do que pode ser descrito como um espaço harmonioso, limpo, calmo, e regrado. Se há uma pista de esqueite, então, obviamente, os esqueitistas deveriam usar apenas a pista. Como se não tivessem o direito de andar de esqueite em outras partes da praça. Caso as regras não sejam obedecidas, então a polícia deve ser munida de meios para identificar e punir os agentes perturbadores.

Em uma sociedade onde a propriedade (privada e pública) é sagrada, a intervenção artística, anda que não danifique permanentemente as propriedades, é considerada vandalismo. No Brasil, existe um esforço por parte da mídia local e das autoridades de reafirmar a pichação como uma forma de depredação. Classificada desta forma, deixa de ser um assunto político, cultural, ou educacional, para se tornar um assunto de polícia. Enquadrada como crime, é tratada como se fosse um crime qualquer. A mídia atua, dessa forma, como agente de propaganda para uma operação psicológica de constituição do espaço público asséptico. Pode-se afirmar que a soma da propaganda com o videomonitoramento, somados ao esforço de intervir nas normas de convivência de grupos sociais específicos (como os esqueitistas) faz parte da sociedade de controle em qual vivemos.

A construção de uma sociedade do controle é um processo não planejado. Trata-se 
de um fenômeno social, do qual fazem parte certos agentes privados (como a mídia), que forma alianças pontuais com agentes públicos (como a polícia), funcionando em favor de uma máquina social (no caso, a normatização do espaço). No que toca a disputa sobre o espaço público brasileiro, o resultado de uma sociedade de controle é que os agentes privados atuam em favor de um tipo de apropriação do espaço (inclusive o público), que é a apropriação conforme o ordenamento normatizado do Estado. No caso brasileiro, isso significa uma normatização que valoriza a apropriação de tipo comercial, onde as relações com o espaço, público ou privado, devem ser feitas com respeito absoluto à propriedade. A pichação como expressão cultural espontânea, mesmo em um espaço dedicado a um esporte tradicionalmente ligado ao hip hop, não era aceitável. Se os esqueitistas quisessem continuar a usar aquele espaço, portanto, deduz-se que eles deveriam modificar suas próprias formas de sociabilidade deveriam ser devidamente modelados para uma forma de convívio.

Evidentemente, não são apenas os jornais impressos ou digitais que atuam na propaganda contra a apropriação espontânea do espaço público. O esforço de classificar como vandalismo as apropriações culturais ou políticas não normatizadas como vandalismo também podem faz parte de jornais televisivos, de rádios. A Band News, por exemplo, veiculou uma notícia onde demonizou uma manifestação do movimento feminista que pichou os muros da Catedral da Sé. O programa pode ser encontrado no arquivo Uol, com a seguinte chamada:

A Polícia Civil vai usar imagens de câmeras de segurança para tentar identificar os responsáveis pelas pichações feitas na Catedral da Sé, no Centro de São Paulo. (Band News: "Câmeras de segurança podem ajudar a identificar vândalos”, 02/11/2015) 


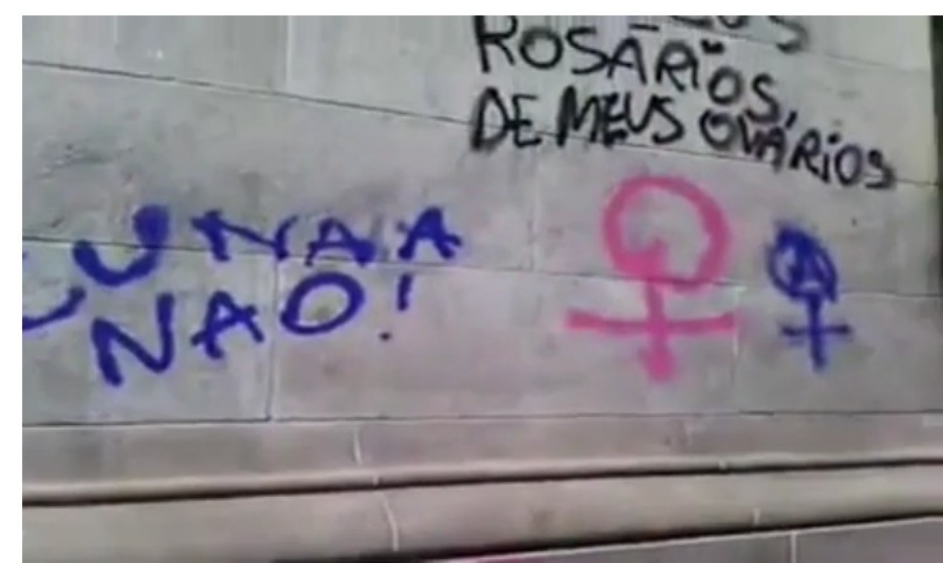

\section{(Imagem extraída da reportagem da Band News: "Câmeras de segurança podem ajudar a identificar vândalos", 02/11/2015)}

A reportagem inicia falando que as portas e paredes da igreja (Catedral da Sé) foram alvo de vandalismo durante o protesto contra o projeto de lei que dificultava o acesso ao aborto. Tratava-se de um projeto de autoria de Eduardo Cunha, então presidente da câmara dos deputados. Entre os dizeres pichados na catedral constavam: "Útero Livre"; "Se o Papa fosse mulher o Aborto seria legal"; "Cunha Não"; "Útero Laico"; e "Tire seus Rosários de meus ovários". A pichação saiu com uma limpeza simples, realizada em um domingo de manhã (menos de 48 horas após o picho).

A intervenção, claramente de caráter político, realizado contra o machismo presente na política, e contra a mistura entre religião e política. Apesar de não ter havido qualquer dano permanente, verificado pelo fato da tinta ter sido facilmente retirada com uma limpeza dos muros realizada em uma única manhã, o ato foi classificado como vandalismo. A polícia foi acionada, e as câmeras de vídeo foram utilizadas, conforme a Band News, para tentar identificar os "vândalos".

Ainda que se critique a depredação de patrimônio público durante atos políticos, é difícil localizar depredação efetiva no uso de tinta de fácil remoção para protestar contra um projeto de lei encabeçado por um deputado que, mais tarde, seria preso por corrupção. Na época, o Brasil ainda vivia efervescência política. As manifestações de rua, no entanto, eram tratadas de forma bastante distintas pela mídia a depender de quais grupos a compunham, e quais ferramentas de intervenção no espaço utilizavam. $O$ 
movimento feminista radical, mesmo quando realizou uma ação pacífica, com tintas removíveis para passar uma mensagem, foi tratado como criminoso. O que se criticou, na notícia, não foi o conteúdo da pichação, mas sim sua forma: a de uma pichação.

A intervenção artística ou política em marcos históricos da cidade como forma de protesto é prática comum. Faz parte da tradição da disputa política no espaço urbano. Os marcos possuem significado na cultura da população. Representam momentos históricos ou ideologias específicas, que certamente agradam a alguns grupos sociais, e desagradam outros. No entanto, os movimentos políticos tendem a recorrer à intervenções que não causem danos permanentes. Estátuas são pichadas, mas raramente destruídas. Apesar do limite escolhido pelos próprios grupos que protestam contra ideologias e políticas consideradas por eles como atrasadas ou nocivas, a mídia os classifica como vândalos criminosos. Clamam que seja usado todo rigor da lei contra aqueles que ousaram perturbar o espaço público.

O trecho abaixo foi retirado de uma reportagem do jornal G1. A reportagem conta sobre uma "pichação" realizada no Monumento às Bandeiras, e na estátua de Borba Gato. A pichação consistiu na pintura, em jato, em tinta azul, rosa, e amarelo, "sujando" o monumento. O trecho selecionado explica como um casal foi flagrado pela câmera de segurança carregando um compressor de jato de tinta, usado para "pichar" o monumento:

\footnotetext{
Uma câmera de segurança registrou o momento em que o Monumento às Bandeiras, na região do Ibirapuera, Zona Sul de São Paulo, é pichado. A depredação ocorreu na madrugada desta sexta-feira (30). A estátua de Borba Gato também amanheceu pintado.

A polícia analisa as imagens, feitas à $1 \mathrm{~h} 56$. Nelas, um casal aparece puxando um carrinho com um compressor de jato de tinta. A pichação começa por baixo do monumento. Em seguida, parece que o casal troca a tinta e continua a tingir a obra de Victor Brecheret, desta vez na parte de cima. Depois, o casal vai para outro lado do monumento, fora do alcance da câmera. A ação dos dois levou menos de dois minutos. (Jornal G1: "Câmera registra casal pichando o Monumento às Bandeiras, em SP", 30/09/2016).
}

O Monumento às Bandeiras e a estátua de Borba Gato são monumentos polêmicos mantidos pela cidade de São Paulo. Glorificam os "bandeirantes", figuras históricas do Estado de São Paulo. A eles são atribuídos feitos como desbravar o interior do Brasil e a descoberta de ouro em Minas Gerais. No entanto, a principal função das bandeiras era 
fazer expedições de caça a índios para escravização.

A "pichação" pode ser considerada uma intervenção artística. Manchar as obras com tinta foi, simbolicamente, afirmar que as figuras exaltadas são uma mancha na história do Brasil. Foi uma forma de demonstrar o desprezo pela figura do escravizador. Essa apropriação livre do espaço, ressignificando uma obra instalada, no entanto, é considerada um crime contra o patrimônio público. A norma de utilização do espaço, a qual a sociedade é submetida pelo intermédio do Estado, não aceita tal comportamento. As câmeras de segurança, nesse sentido, foram usadas para tentar, sem sucesso até a realização da reportagem, identificar os envolvidos.

Além de ser claro o uso de mecanismos de segurança em uma espécie de guerra constante para normatização do uso do espaço público, fica clara a dificuldade da polícia em identificar os envolvidos. Câmeras de segurança são de pouca serventia quando os filmados não expõe características óbvias (carro que usaram, seus rostos, símbolos que portam, etc.). Ainda, sem que haja informações suficientes, ou registro dos "transgressores" em bancos de dados, as câmeras apenas servem para identificar o ocorrido, e não os envolvidos. Na prática, a apropriação do espaço, quando realizada de forma difusa, não organizada, e com cautela para que as câmeras não identifiquem os indivíduos, ainda pode ser realizada esporadicamente, mesmo contra o controle normatizador do espaço.

A dificuldade de identificar os "transgressores" (na verdade, trata-se da dificuldade do videomonitoramento identificar autores de intervenções disruptoras no espaço público) não impede a mídia brasileira de continuar a difundir o mito de que câmeras de vídeo podem mudar a realidade do espaço público urbano. A pichação é uma das formas de apropriação do espaço público mais atacadas pela mídia. Um dos efeitos disso é que parte das autoridades locais se veem compelidas a apresentar respostas para o "problema" da pichação. João Dória ${ }^{44}$, então prefeito de São Paulo, apresentou sua própria solução, em 2017. Declarou guerra aos pichadores, apagou grafites, e investiu em videomonitoramento, supostamente para impedir as pichações. O jornal $\mathrm{G} 1$, da globo, assim noticiou a iniciativa do então prefeito:

44 O fato do Prefeito João Dória Jr. dedicar-se a aprovar projetos e realizar ações sempre com especial atenção ao marketing realizado em torno de sua imagem, o rendeu o apelido, entre seus opositores, de Prefake (o que pode ser traduzido para Prefeito de mentirinha, ou Prefeito falso). 
O prefeito João Doria (PSDB) sancionou na manhã desta segunda-feira (20) o projeto de lei que pune pichadores com multas que variam entre $R \$ 5$ mil e $R \$ 10$ mil. O projeto de lei foi aprovado na terça-feira (14) da semana passada pelos vereadores da Câmara de São Paulo. (...) O prefeito disse que a cidade de São Paulo terá em breve 2500 câmeras integradas ao Copom da Policia Militar através do Detecta para reforçar a fiscalização contra os pichadores. (G1 São Paulo: "Doria sanciona lei que penaliza pichadores com multa", 20/02/2017)

As câmeras a qual João Dória Jr. se referiu são as mesmas utilizadas no projeto City Câmeras, que conforme a notícia, nasceu como uma solução para guerra ao picho. A expressão guerra ao picho não é meramente ilustrativa. Entre janeiro e fevereiro de 2017, foram presos 83 pichadores, conforme a reportagem. Os mesmos foram indiciados criminalmente, por crime ambiental, e judicialmente por dano ao patrimônio. A partir de fevereiro, os indiciados passaram a ter que pagar multa.

Interessante notar que em momento algum nenhuma das reportagens localizadas levantou a questão de porque o picho é considerado crime ambiental. Desde a lei 9.605/98 (Lei de Crimes Ambientais), a conspurcação de edificação ou monumento urbano é crime ambiental. A lei isenta "a prática de grafite realizada com o objetivo de valorizar o patrimônio público ou privado mediante manifestação artística, desde que consentida pelo proprietário (...)". Na prática, isso significa que é crime ambiental porque desvaloriza a edificação ou o monumento, e é estaticamente desagradável.

O esforço pela demonização do picho (político, cultural, e artístico), o clamor pelo uso de videomonitoramento, e o anseio pela punição dos envolvidos se justifica, na prática, pelos gostos e padrões estéticos estabelecidos. Pela normatização formal daquilo que é ou não aceitável no espaço público, sem considerar o caráter orgânico e mutável da relação cultural com o espaço. A mídia atua como verdadeiro agente de propaganda cinza, acusando e classificando as manifestações políticas e culturais das quais discorda com termos pejorativos e imprecisos, sem precisar assumir qualquer responsabilidade por isso. Joga uma parcela da população contra outra, sem tentar esclarecer o debate em torno das ações. Na verdade, os jornais referidos parecem mais preocupados, nos casos citados sobre pichações, em se posicionar politicamente contra a intervenção realizada, do que esclarecer possíveis mensagens que a intervenção desejava passar. Atuaram para construir uma opinião pública contra uma forma cultural de apropriação do espaço público 
e/ou urbano. 


\section{ASPECTOS DO IMPACTO DA GUERRA PSICOLÓGICA NA ATUAÇÃO}

ESPACIAL DO "INIMIGO"

A guerra psicológica contra a apropriação espontânea do espaço não se resumiu, evidentemente, ao Sistema Detecta. Na verdade, é uma guerra prolongada, que iniciou-se antes, e não há nenhum indício de sua possibilidade de resolução no próximo período. Isso porque tem como base a divisão da sociedade em projetos antagônicos, que tem como base social, parcelas da população que são, no Brasil, também antagônicas. A guerra psicológica, além de tentar criar unidade na população aliada à quem realiza a operação psicológica, visa atrair a população neutra. Ainda, objetiva dividir, desarticular, desmoralizar, e induzir ao erro a população hostil. Para presente análise, isso significa dizer que parte das notícias veiculadas, durante os anos 2014 e 2017, tiveram o intuito de desmoralizar a apropriação espontânea do espaço. Ainda, a forma de noticiar os fatos buscou ressaltar a forte probabilidade dos grupos envolvidos serem punidos, com o intuito de amedrontá-los. As principais técnicas de propaganda ao inimigo utilizada foram: (i) a descrição das ações diretas de apropriação do espaço como fruto de grupos pequenos e radicais (criação de divisão entre "soltados" e "cidadãos" das forças inimigas); (ii) insinuação de que a apropriação espontânea do espaço está ligada a grupos políticos ou culturais com interesses distintos do restante da população (criação de divisão entre liderança e massa das forças adversárias); e (iii) afirmação que os responsáveis serão investigados e punidos (criação de medo da derrota certa).

A técnica de induzir o adversário ao erro pode ocorrer de duas formas: a primeira é através da divulgação de falsa informação (indução consciente ao erro). A segunda é como resultado das três técnicas supracitadas (indução ao erro por desorganização do adversário). Dado o caráter difuso da guerra psicológica pelo espaço público em São Paulo, e o não alinhamento automático da mídia local à Secretaria de Segurança Pública do Estado de São Paulo, a indução por veiculação de falsa informação ocorre muito raramente. No entanto, no presente capítulo será demonstrado que como as demais técnicas foram aplicadas com sucesso, os agentes envolvidos na apropriação espontânea do espaço (considerados perturbadores da ordem pelos favoráveis à utopia do espaço asséptico) foram induzidos ao erro. Em grande parte devido à paranoia resultante da superestimação de que as polícias civis e militares estariam mais preocupadas em 
identificar os envolvidos do que em achar os "culpados de sempre"45

\title{
4.1 VIDEOMONITORAMENTO E O CONTROLE POLÍTICO
}

Além de servir para localizar participantes diretos em ações de apropriação não normativa do espaço público (pichação, manifestações de rua não autorizadas, etc), o videomonitoramento tem sido utilizado como ferramenta para perseguição política. Como parte de uma política de modulamento do conjunto político da sociedade, as câmeras podem ser usadas para identificar e desarticular movimentos políticos, culturais, ou sociais que sejam considerados nocivos para sociedade, ou desrespeitoso às normas de convivência. Algumas reportagens, mesmo quando apoiam a ação da polícia, e entendem que ela agiu de acordo com a lei, não escondem o interesse político por trás da ação.

\begin{abstract}
A polícia prendeu em São Paulo, nesta quinta-feira (24), um professor acusado de ser um dos black blocs que promovem vandalismo em manifestações na capital, incluindo depredações de agências bancárias.

Jefte Rodrigues do Nascimento, de 30 anos, foi identificado em imagens de câmeras de segurança. Na casa dele, foram encontradas roupas usadas durante a depredação de uma agência bancária.

Detido na manhã de hoje, ele confessou ter participado do quebra-quebra durante uma manifestação do Movimento Passe Livre, no mês passado em São Paulo. (Jornal da Band: "Professor acusado de ser black block é preso", 24/07/2014)
\end{abstract}

Em uma reportagem de julho de 2014, o Jornal da Band relatou a prisão de um manifestante que participou da depredação de uma agência bancária. $\mathrm{O}$ trecho selecionado, acima, conta como a identificação dele foi possível através do uso de câmeras de segurança. Apesar de possuir as imagens do ato de vandalismo, a polícia demorou um mês para identificar corretamente o suspeito.

A depredação de propriedade privada é um crime, e quando o responsável é identificado, a lei manda que ele seja punido. O caso em isolado poderia ser considerado apenas mais um crime comum onde o suspeito foi identificado via imagens de câmeras de segurança. No entanto, a forma de divulgação na mídia convencional torna o caso

\footnotetext{
45 A expressão "culpados de sempre” é eufemismo para perseguição política ou para o racismo de agentes policiais, que procuram localizar pessoas de "comportamento suspeito" e atribuir a eles crimes que foram realizados próximo ao local.
} 
qualitativamente diferente. $\mathrm{O}$ ato de vandalismo ganhou menos importância do que (a) 0 manifestante ser um professor; (b) ele ser suspeito de ser integrante do "black bloc" (que é uma tática, mas que a mídia e a polícia tratam como se fossem um grupo); e (c) o vandalismo ter sido decorrência de uma manifestação política.

Não é contado, na reportagem, que as depredações ocorreram após o início de um conflito com a polícia, que impediu a passagem dos manifestantes, e que tentou os dispersar com tiros de borracha e bomba de gás. Se considerada a versão dos manifestantes, a quebra de propriedade particular foi uma forma de chamar a atenção da polícia, permitindo que os demais manifestantes fugissem sem maiores problemas. Nesse sentido, o patrimônio privado foi uma "baixa" de um conflito sobre o uso do espaço público. É por isso que o black bloc é tratado como um grupo, pois se identifica neles uma espécie de comissão de segurança das passeatas.

Apesar das penas para a depredação de patrimônio serem relativamente pequenas, a punição serve de exemplo para impedir que manifestantes voltem a usar tática de defesa similar. Espera-se que, uma vez confrontados pela polícia, aqueles que tentam fazer valer o direito que acreditam ter de ocupar o espaço público se disperse pacificamente. Daí a mídia nunca tratar os Black Blocs como um movimento de autodefesa.

\begin{abstract}
A Polícia Civil vai usar imagens da imprensa e de câmeras de segurança para tentar identificar as pessoas que depredaram uma viatura no Largo do Arouche, no centro, durante a passagem de um protesto, nesta quarta (31). Os manifestantes, que iniciaram na Avenida Paulista um ato contra o impeachment da ex-presidente Dilma Rousseff, desceram a Rua da Consolação e se dirigiram à Praça da República. (...) No momento da destruição, um policial que conduziria o carro se afastou e nada pôde fazer para evitar a ação. Apesar de os principais autores estarem encapuzados, é possível ver alguns o rosto descoberto. Casos localizados e detidos, eles poderão responder por dano ao patrimônio. (Revista Veja São Paulo: "Polícia tenta identificar manifestantes que destruíram viatura", 01/09/2016)
\end{abstract}

O trecho acima foi retirado de uma reportagem do site da Revista Veja São Paulo. A reportagem conta como um grupo de manifestantes, em meio ao ato contra o impeachment da presidenta Dilma Russef, depredaram uma viatura de polícia, além de jogar pedras em agências bancárias. A reportagem ressalta que, apesar de parte dos 
envolvidos estarem com rostos cobertos, alguns estavam com a cara a mostra. Afirma-se que a polícia utilizaria imagens de câmera de segurança, e fotos de jornalistas, para identificar os "vândalos". A revista Veja, sempre defensora do papel da polícia na organização social, não contou que, mais uma vez, a ação dos manifestantes se deu após a tentativa da polícia em dispersar o ato.

A reportagem é relevante por ressaltar: (a) que as câmeras de segurança iriam ser usadas para identificar manifestantes; e (b) que alguns manifestantes estavam de rosto coberto. Aqueles que são normalmente acusados de ser black blocs costumar proteger seus rostos para evitar possíveis identificações enquanto confrontam a polícia, ou depredam patrimônio para chamar a atenção do efetivo policial, distanciando-os do restante dos manifestantes (conforme mandam os manuais da tática de black bloc).

Quando uma apropriação do espaço público, na forma de uma passeata, é reprimida pela polícia, pode ocorrer confronto com aqueles que se acham no direito de protestar. Trata-se de um confronto entre duas visões do que é o espaço público: se é o locus da política, ou se é um espaço para o trânsito e para convivência mediada pelo consumo. Nessa ocasião, o confronto teórico se torna físico, levando a danos. Manifestantes se machucam, e propriedades (inclusiva propriedade da polícia) podem ser danificadas. Além de enfrentar a força policial no ato da dispersão, os manifestantes são alvo do videomonitoramento, usado para punir, posteriormente, os que resistiram.

Ambas notícias trataram de forma pejorativa os manifestantes, sem dar qualquer possibilidade que testemunhas favoráveis ou apoiadores dos grupos mais radicais expressassem sua visão sobre o acontecido ${ }^{46}$. Ainda, ressaltaram que os envolvidos seriam punidos por sua ação radical. Além disso, em ambos os casos separou a ação de "vândalos" e "black blocs" da ação dos manifestantes pacíficos.

Mas a guerra psicológica não é lutada apenas pelos apoiadores da utopia do espaço asséptico. Alguns jornais (de menor porte) entendem que o espaço público é o locus do conflito político. Que é direito da população se manifestar. Esses mesmos jornais tentam denunciar os excessos da polícia, e dão voz à narrativa dos manifestantes.

46 É curioso notar que em ambos os casos os manifestantes foram acusados de depredar patrimônio. Caso tivessem apenas pichado viaturas e vitrines de banco, teriam sido acusados de depredação do patrimônio e crime ambiental. Aparentemente, um manifestante está mais seguro quando danifica permanentemente um patrimônio, sem passar mensagem nenhuma, do que quando não o danifica permanentemente, mas passa tenta passar uma mensagem. 
Conforme uma reportagem do jornal GGN, de onde foram tirados os trechos a seguir, a polícia é acusada de, na cidade de São Paulo, perseguir e espancar estudantes que participaram de ocupações de escolas. A reportagem conta como os jovens são seguidos em espaços públicos, e em especial no metrô de São Paulo. Em situações que se viram sozinhos, foram abordados pela polícia. A reportagem aponta três relatos de violência policial contra jovens que participaram de movimentos políticos:

\begin{abstract}
A polícia paulistana é acusada de carregar uma lista com fotos e nomes de secundaristas e apoiadores do movimento. Ao ser abordado, o jovem é obrigado a reconhecer os colegas apresentados nas imagens. Quem não consegue, é espancado. Apesar da denúncia internacional, em abril, as perseguições não cessaram, pelo contrário, se tornaram mais frequente e violentas, segundo fontes ouvidas pelo jornal GGN. (...) A maioria das imagens utilizadas pela PM nas abordagens são de câmeras de segurança pública da região da Avenida Paulista e das linhas do Metrô e CPTM, apontando para a participação de outras estruturas de segurança do governo do Estado na estratégia de perseguição. (...) Há também relatos de dois jovens que, retornando de manifestações, foram abordados por policiais que os obrigaram a segurar uma bomba de efeito moral nas mãos enquanto um PM ameaçava tirar o pino. 'Os policiais ainda falavam que se deixasse cair no chão, iam apanhar até morrer'. (GGN: "Secundaristas são perseguidos e espancados por PMs em SP". 01/11/2016)
\end{abstract}

Os trechos selecionados ressaltam que para perseguir os jovens, o grupo de policiais utilizaram fotos com identificação de ativistas. As fotos foram conseguidas através das câmeras de segurança instaladas em espaço público. Isso indica que ou (a) o comando da polícia aprovou essa forma de perseguição; ou (b) elementos organizados (os chamados "grupos de extermínio") tem acesso a imagens das câmeras.

O grau de independência da polícia, e de policiais, para tomar decisão sobre formas de reprimir, somado à impunidade aos excessos, transformaram o sistema de videomonitoramento em mais uma ferramenta nas mão de um Estado Policial. Aquilo que foi instalado com o argumento de garantir a segurança pública, passou a ser usado como mecanismo para reprimir e oprimir a população. A perseguição, humilhação, e espancamento de ativistas é, por si só, uma peça de operação psicológica. O intuito é espalhar o terror. Somado à constante propaganda que os manifestantes podem ser identificados e punidos, cria-se um clima de terror mesmo entre manifestantes que não tem interesse em realizar qualquer tipo de confrontamento direto. 


\title{
4.2 SOCIEDADE DE CONTROLE E O MEDO DA DITADURA
}

As experiências recentes no Brasil fazem com que haja desconfiança da população quanto a vigilância e a repressão. A experiência democrática é ainda pequena. Foram poucos os anos que o país experimentou o direito pleno de se expressar no espaço público. Na verdade, o período mais longo de democracia plena no Brasil foi o que durou de 1985 até 2016. Parte da população desconfia que o afastamento da presidenta Dilma, em 2016, foi uma ruptura da constituição. Mas desde os anos anteriores, havia o temor que a crescente capacidade da polícia em vigiar fosse um sinal de retorno de uma futura ditadura.

As práticas policiais que ainda vigoram são aquelas que vieram da tradição repressora, fortalecida por 20 anos de ditadura militar. Mas, desde antes, as polícias estaduais serviam ao controle político da população. A era vargas, e mesmo a república velha, foram caracterizadas pelo cerceamento das liberdades democráticas.

\begin{abstract}
"Essa cultura de reprimir manifestação é errada. A manifestação, mesmo para os que são contra, tem que ser tolerada. - Julio Cesar Fernandes Neves. O ouvidor vai além. 'Isso que você está relatando eu lembro que existia em plena Ditadura [Militar]. Essa preocupação com gente seguindo tínhamos naquela época e os métodos são muito semelhantes.' (...) Neves também fala sobre a possibilidade de policiais infiltrados em grupos de manifestantes e sobre interceptações de ligações. 'As pessoas não têm segurança nenhuma com relação a presença de infiltrados em manifestações, já que ficou claro que existiu infiltrado [em referência a prisão de 26 pessoas no Centro Cultural São Paulo], há possibilidade de existir outros [infiltrados] sim, mas o pessoal do governo nega peremptoriamente. Possibilidade de grampo telefônico também existem.' Depois de ter acesso às queixas de perseguição das pessoas ouvidas para esta matéria, Julio Cesar Fernandes Neves ressaltou a possibilidade de investigações comandadas pela Polícia Militar. 'Se efetivamente isso está ocorrendo [a perseguição], algum serviço de inteligência pode estar ocorrendo também, porque ninguém estaria com a mesma viatura coincidentemente em lugares tão variados. Então, se ficar claro que isso realmente ocorre, existe um trabalho de inteligência aí e não só o serviço de contenção'." (Revista Vice: "Manifestantes se dizem perseguidos pela polícia de SP", 18/10/2016)
\end{abstract}

Os trechos selecionados acima são parte da reportagem da Revista Vice sobre a perseguição policial que manifestantes dizem sofrer. Os trechos são parte da avaliação realizada ouvidor da polícia militar de São Paulo. Ele foi consultado pelos jornalistas da Vice, que levaram os depoimentos anônimos dos manifestantes. A avaliação feita por ele é clara: se esses relatos forem verdadeiros, não se trataria apenas de uma ação individual 
de policiais, mas seria fruto de serviços de inteligência.

O ouvidor ainda ressaltou: os cenários descritos lembram aqueles que eram relatados na época da Ditadura Militar. A referência à ditadura não é por acaso. O Brasil passou por 20 anos de ditadura (1964-1985), que fortaleceu o caráter persecutório das polícias militares. Com a redemocratização, a cultura política da polícia nunca foi revista. Na prática ela continuava a atuar como "polícia social", que aplicava dois pesos para duas medidas. Os suspeitos pobres eram especialmente reprimidos, mesmo quando a razão da suspeição fosse apenas a aparência do pobre, como parte do racismo institucional. 0 restante da população era tratado com mais respeito. Exceto se o suspeito fosse militante político ou social. Nesses casos, era (e ainda é) observado com cautela.

A memória da Ditadura Militar é recente. Tratou-se de uma experiência de Estado Policial de facto. É natural que, mediante a vigilância realizada pela polícia, a população relate perseguições parecidas com o ocorrido naquela época. Isso é fruto: (a) da memória histórica que a população possui, que faz com que ela reconheça os mesmos métodos daquela época, quer estes sejam empregados ou não; e (b) a própria polícia ainda está organizada da mesma forma daquela época, e por isso pratica os mesmos métodos.

No Brasil, a sociedade de controle tomou um aspecto específico para os militantes sociais: o receio da continuidade, ou retorno, da Ditadura Militar. Anos de perseguição, e a continuidade de métodos de infiltração policial após a redemocratização, levaram aos militantes adotarem mecanismos de autopoliciamento. Temendo ser infiltrados, há certo receio em criar organização mais complexa. O medo é que, a qualquer momento, a ditadura volte, de fato ou de forma simbólica, e persiga os militantes organizados radicalmente.

A consequência para a apropriação do espaço público, de forma política, é que a pauta pelo uso do espaço sofra transição de pautas sociais, culturais, econômicas, etc, para a pauta de democratização. Ainda, qualquer tipo de policiamento, ou de segurança pública, é vista como uma ameaça ao uso democrático do espaço. Evidentemente, esse medo é fruto da observação empírica anterior dos militantes, que passam esse medo para as gerações de militantes que se sucedem. 


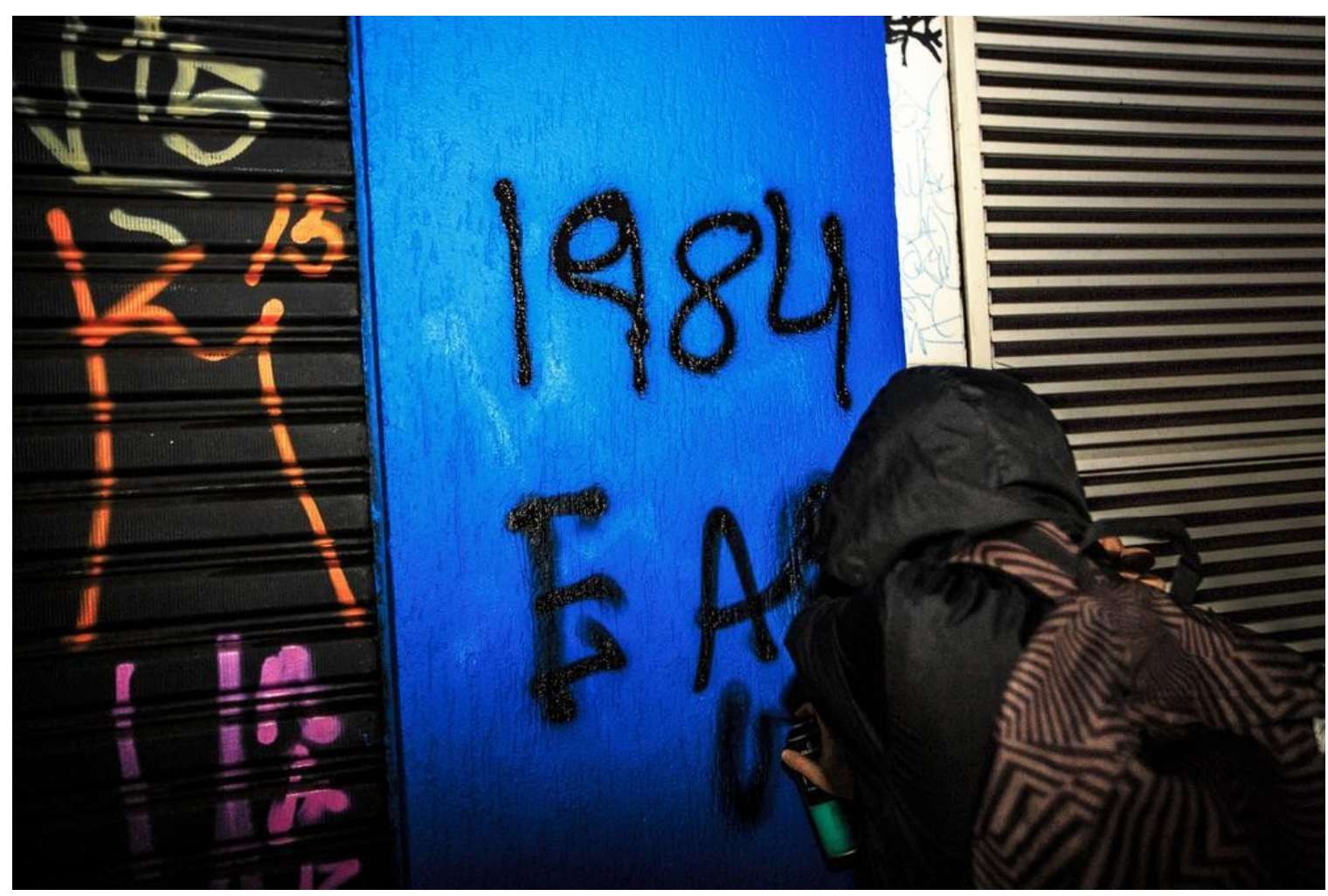

Foto: Felipe Larozza/ VICE

Dessa forma, toda ocupação de espaço público, quando se propõe publiciza de forma política, aborda, além das pautas específicas, o problema da repressão policial e da "fascistização" da sociedade. O movimento de estudantes, em especial o de estudantes do ensino fundamental e médio, recém-redespertados, se coloca lutando pelo seu direito ao espaço político (e portanto ao espaço público). Lutam pelas escolas, pelas ruas, pelas praças, por seus locais de socialização. A foto retirada por Felipe Larozza, da Vice, reproduzida na reportagem supracitada, expressa de forma bastante simbólica essa disputa pelo espaço.

Os trechos selecionados abaixo fazem parte da reportagem da Revista Veja "Empresas de segurança privada monitoram black blocs". A revista é conhecida por ser defensora da normatização e controle estatal sobre os espaços públicos. Ela tem como linha a compreensão do espaço público como local de trânsito e consumo. Dessa forma, diante da apropriação do espaço público, defende a propriedade privada:

Além da tática de inteligência com os 'olheiros-fotógrafos', as empresas enviam seguranças à paisana para tentar ouvir os planos dos líderes dos atos ainda na concentração. Os centros comerciais também gravam imagens com câmeras externas e posicionam carros blindados na área externa para intimidar a 
aproximação. O monitoramento prévio de redes sociais serve para dimensionar o tamanho do aparato de segurança e do efetivo de prontidão. Além de adotar ações preventivas como recolher móveis e equipamentos externos e solicitar a presença da Polícia Militar. Hotéis, restaurantes, hospitais, lojas de departamento e supermercados também adotaram novas ações preventivas após o ano passado. (...) Desconectados da real intenção dos jovens - 'paquerar, zoar e dar uma volta em lojas de grifes que admiram' -, movimentos sociais de esquerda fizeram da proibição aos 'rolezinhos' bandeira da 'luta de classes' e desfiguraram os encontros com a criação de um ato contra a discriminação, o 'rolezão'. Desde então, as empresas de segurança elevaram o grau de apreensão com protestos de pauta politica. (Revista Veja: "Empresas de segurança privada monitoram black blocs", 24/03/2014)

$\mathrm{Na}$ reportagem, a revista relata o uso de seguranças particulares por parte de estabelecimentos empresariais e comerciais para se proteger de "black blocs" e de membros dos "rolezinhos". Embora a reportagem se refira com maior atenção aos protestos realizados contra a Copa do Mundo, se estende aos encontros de jovens para lazer, denominados "rolezinhos". Trata-se de dois fenômenos bastante distintos, mas que, ao serem abordados como similares, demonstram a lógica de segurança ainda herdeira da ditadura militar. Primeiro, é importante lembrar que, durante a ditadura, parte do controle político sobre a população foi delegada a grupos paramilitares organizados por empresas e por indivíduos "preocupados com a segurança". Esses grupos se infiltravam entre manifestantes e membros da esquerda a fim de, posteriormente, caçar os "comunistas".

O que a revista Veja relata é um procedimento similar. O método descrito é o uso de agentes infiltrados e o monitoramento de redes sociais. Os agentes (privados) infiltrados buscavam identificar as lideranças dos movimentos, levantar trajetos de passeatas, e possíveis intensões. A maior preocupação era identificar os "black blocs". Por esse nome, entendia-se todo e qualquer manifestante que adotasse a prática violenta contra a propriedade ou contra policiais. Na época, o termo "black bloc", que vem de um tipo de tática adotada internacionalmente por movimentos de protesto, se tornou, no Brasil, sinônimo de "vândalos politicamente organizados".

A justificativa de combate aos "vândalos politicamente organizados" se estendeu, na reportagem da revista Veja, aos "rolezinhos". Esses eram reuniões de jovens que queriam aproveitar os espaços de socialização (praças, parques, shoppings) para se reunir e, evidentemente, socializar. Os eventos eram organizados pela internet. Quando 
os "rolezinhos" foram realizados em shoppings, o grande número de jovens (pobres e, em grande número, negros) assustaram a "clientela" e os lojistas. O recorte racista e classista era bastante claro: aquele ambiente não deveria ser usado por pessoas de baixa renda. Como alguns rolezinhos acabaram tendo tumulto, os shoppings passaram a proibi-los de antemão. Parte dos movimentos políticos se declararam contra a proibição.

Isso se tornou desculpa, aos olhos da Veja, para acusar os "rolezinhos" de terem se politizado, se tornando um movimento infiltrado pela esquerda. A justificativa é a mesma utilizada na época da ditadura militar para fechar centros estudantis, centros culturais, etc.: a "infiltração da esquerda". Trata-se de um artifício típico de Estados Policiais, que envolve perseguir um grupo político e transformá-lo em um suposto "perigo social". Com a desculpa de combater esse perigo social, os ambientes de socialização que fogem do controle direto do Estado podem ser um a um fechados. Com o passar do tempo os "rolezinhos" perderam espaço, dado a propaganda negativa e série de proibições que foram feitas pelo setor privado, com a conivência da polícia.

\subsection{UMA CIÊNCIA DE CONTROLE DO PÚBLICO}

No Brasil, o controle policial sobre a população é tratado pelas secretarias de segurança como uma ciência. Os funcionários da segurança são treinados em técnicas de investigação direcionada. A cada nova geração, são desenvolvidos novos procedimentos para criminalizar, isolar, vigiar, e punir grupos sociais. Aqui, a polícia age, em plena democracia, como se tivesse total liberdade para escolher quais grupos possuem o direito de se organizar ou se manifestar.

O desrespeito aos direitos individuais e sociais também é uma prática comum das companhias privadas. Como resultado, toda tecnologia de informação logo é adaptada para técnicas de controle. Assim, o comportamento das pessoas e grupos podem ser modulados, através de incentivos e barreiras fluidas, ou normalizados através do sistema de punições.

A novidade do "inquérito Black Bloc" é a tentativa de enquadrar grupos de pessoas pelo crime de associação criminosa em vez de investigar individualmente cada delito de vandalismo. Na justificativa da polícia, o fato de indivíduos aparecerem 
várias vezes em situações de depredação indica que há uma coordenação do movimento, que não se trata de algo espontâneo.(...) Naquele sábado, diversos interrogados relataram terem ouvido perguntas sobre sua filiação a partidos, sua participação em movimentos sociais e até mesmo em quem haviam votado nas últimas eleições. Muitos tiveram que explicar o motivo de terem ido a manifestações e a quantas haviam comparecido. (...) O diretor do Deic, Wagner Giudice, exibiu em coletiva de imprensa tudo o que foi apreendido, como máscaras do soldado britânico Guy Fawkes - usada como símbolo do grupo hacker Anonymous - máscaras de proteção a gás lacrimogêneo, faixas de protesto, sprays de tinta, um par de botas e cinco computadores. "Foi a primeira vez que conseguimos cumprir os mandados de busca e apreensão, tendo em vista as manifestações de hoje. Nós sabíamos que alguns desses tinham cometido crimes anteriormente, então fomos às casas deles". (A. Pública: "O Inquérito do Black Bloc", 28/02/2014)

Os trechos acima foram retirados de uma reportagem da Agência Pública. Trata-se de um portal de notícias independente, produzido sem fins lucrativos, e que afirma partir do ponto de vista da população na investigação de assuntos do interesse público. A Pública é financiada pelos grupos: Fundação Ford; Instituto Betty e Jacob Lafer; Open Society Fundations; Crowdfunding Reportagem Pública; Oak Fundation. As renomadas instituições financiadoras, que inclui a Open Society Fundations, fundada pelo grande especulador (especializado em câmbio) George Soros, coloca o portal na gama de jornais preocupados com direitos humanos, em especial nos países em desenvolvimento.

A reportagem em questão é um relato do inquérito 01/2013, do Departamento Estadual de Investigações Criminais (Deic) de São Paulo, conhecido como Inquérito do Black Bloc. Os trechos selecionados expõe (a) que segundo a polícia os atos de depredação realizados por Black Blocs demonstram grau de organização, classificando os "bloquers" como um grupo organizado; (b) que as pessoas escutadas no inquérito foram questionadas quanto a suas posições políticas, demonstrando a preocupação em classificar os manifestantes como "vândalos politizados" organizados em um grupo; e (c) o fato da identificação dos manifestantes ter sido usada para realizar operações de busca e apreensão preventiva, visando inviabilizar a participação dos manifestantes em uma manifestação que estava marcada para o dia.

A prática de classificar manifestantes como "esquerdistas radicais" lembra, mais uma vez, as práticas da ditadura militar. O fato de se tratar de uma investigação para desbaratar um suposto grupo político que radicaliza em manifestações, a fim de impedir que esse grupo voltasse a disputar as ruas, demonstra o sentido preventivo. Trata-se de 
uma tentativa de controlar o uso do espaço público.

Segundo os manifestantes, as ações de black blocs em geral se dava depois que a polícia militar iniciava a repressão contra as passeatas e outros eventos. Segundo o manual internacional dos black blocs, a tática de radicalização deve ser usada defensivamente. Esse relato é compatível com a narrativa traçada nos telejornais. Comumente, os atos de vandalização aparecem no meio da noite, quando o sol já se pôs. No entanto, as fotos e filmagens da repressão policial aparecem com o sol ainda por se pôr. Se considerado o sentido cronológico das imagens (ao invés da cronologia narrada nos telejornais), a repressão policial necessariamente precede as agressões.

Se essa narrativa for considerada como verdadeira, o Inquérito Black Bloc visava retirar das ruas os manifestantes que provavelmente resistiriam na ocasião de possível repressão policial. Dessa forma, o inquérito se encaixa como uma ação de disputa do espaço público. É uma forma da polícia dizer "se os manifestantes quiserem protestar, eles devem o fazer dentro de nossas regras e nosso comando, e jamais resistir às nossas decisões”. É a tentativa de impor a normatização do espaço através da desorganização e repressão sobre aqueles que resistem a ela.

O repórter Matias Maxx relatou, na revista Vice a sua participação no $V$ Seminário de Segurança da LAAD, onde ocorreram palestras da ABIN, e empresas de segurança apresentaram "soluções tecnológicas" para o problema da segurança pública. O LAAD Security é uma feira internacional anual onde novas tecnologias são apresentadas a um público restrito. Algumas palestras não podem ser gravadas:

Uma das novidades em questão seria um aparelho que combina telefone celular e radio, e que fixado ao colete do policial funcionaria como uma 'body câmera', registrando e transmitindo para um centro de controle vídeo, GPS e outros metadados relativos a movimentação do agente. (...) O gerente de vendas Alexandre Giarola explicou que 'isso significa você criar a noção de contexto para tomada de decisões, porque antes você conversava com sua operação via rádio, agora não, a posição de tomada de decisão e de operação vai ter múltiplos inputs como câmera, mapa, dados coletados em mídias sociais e aplicações rodando como o Full Face, que é um reconhecimento facial.' (...) Outro recurso apresentado pelo engenheiro foi o BriefCam Syndex. 'Digamos que você tem uma ocorrência aonde você sabe que o suspeito está vestido de vermelho e foi naquela direção, então esse sistema pega as câmeras daquela região e sintetiza, por exemplo, uma hora de vídeo em três minutos, mostrando toda as pessoas de vermelho que passaram em frente às câmeras caminhando nessa determinada direção e em cima dela o horário em que ela passou'." (Revista Vice: "Reconhecimento facial e redes sociais monitoradas: as armas da ABIN contra a ameaça do Estado Islâmico ao Brasil?", 
Apesar da principal preocupação dos apresentadores das tecnologias ter sido ressaltar a importância de prever possíveis ações terroristas do Estado Islâmico, os Black Blocs foram citados também como possíveis alvos de vigilância. Muitos dos equipamentos apresentados seriam utilizados melhor em acompanhamentos de manifestações e eventos, do que em outras situações.

Os trechos selecionados da reportagem "Reconhecimento facial e redes sociais monitoradas: as armas da ABIN contra a ameaça do Estado Islâmico ao Brasil?" revelam três tecnologias distintas que podiam ser combinadas para vigiar o público. A primeira é uma câmera de corpo, capaz de captar imagens e sons, e transmitir a um comando móvel os dados coletados, assim como metadados de localização e horário da coleta das imagens e sons. A segunda era o software "Full Face", software que tem como função identificar o rosto de pessoas e procurar em um banco de dados, facilitando a identificação rápida.

O banco de dados pode ser composto por imagens coletadas em mídia social, antes de um protesto, por exemplo. A terceira tecnologia é o BriefCam Syndex, que pode ser usado tanto em conjunto com as câmeras de corpo como com as câmeras de segurança previamente instaladas. Ele permite filtrar as imagens a partir de características e dados inseridos no programa. Dessa forma, pode-se acompanhar o movimento de um único manifestante nas imagens coletadas, reconstruindo seu trajeto, ou mesmo identificando rapidamente em que direção ele se movimentos em meio a um tumulto.

Embora a tecnologia de fato possa ser usada para identificar terroristas, ou mesmo criminosos comuns, a combinação das três pressupõe: (a) que tenha se coletado anteriormente fotos e dados sobre os suspeitos; (b) que haja pessoal equipado com câmeras móveis e em comunicação com um centro móvel; e (c) que a vigilância se dê sobre um evento em local onde haja câmeras de seguranças instaladas. Essas características mais comumente ocorrem juntas quando há monitoramento de eventos públicos, ou manifestações. Ainda, trata-se de uma ferramenta de controle do espaço. Visa munir a polícia de melhores ferramentas para atuar rapidamente em conflitos de rua, 
em especial quando há uma multidão de transeuntes. Essa tecnologia pode ser utilizada facilmente para identificar pichadores e manifestantes previamente selecionados pela polícia.

\subsection{VIDEOMONITORAMENTO E VIOLÊNCIA}

A conjunção da sociedade de controle com um Estado Policial leva a um acirramento dos efeitos da vigilância sobre o espaço público. No entanto, a simples existência de uma sociedade de controle não significa que haja um Estado Policial. No caso brasileiro, esse tipo de Estado está em vias de ser formado, mas ainda não se configura em sua completude. A violência policial, a independência da mesma para realizar livremente sua repressão, e o direcionamento político de suas forças, apontam para a transformação da polícia em uma força política organizadora da sociedade (e portanto, do espaço público).

A transformação da polícia em força política significa a transformação dessa em agente proponente de normas para o uso do espaço público. Ainda, ela que decide quais os usos não normatizados podem ser aceitos ou não. Na prática, a polícia se coloca como um agente de suma importância no conflito da própria definição do que deve ser o espaço público: se um local de trânsito e consumo; ou se um local de expressão cultural e discussão política.

Abaixo temos uma reportagem do Portal da Central dos Trabalhadores e Trabalhadoras do Brasil. A reportagem traz uma coletânea de depoimentos sobre a repressão policial a uma manifestação de estudantes e apoiadores, ocorridos no dia 09/12/2015. Tratava-se de uma passeata de alunos e apoiadores de ocupações de escolas, realizadas para tentar barrar a "reorganização" do ensino do Estado de São Paulo. A manifestação ocorreu na Avenida Paulista. Nos trechos selecionados, é descrito como a polícia teria atacado estudantes por eles terem chamado os policiais de fascistas:

Ocupando escolas há um mês e resistindo ao projeto de 'reorganziação escolar' do governo do estado de São Paulo, os secundaristas paulistas começaram um protesto nesta quarta-feira (9) no vão do Masp, na avenida Paulista. Pacificamente, aproximadamente 15 mil pessoas marcharam pelas ruas em direção à Secretaria Estadual de Educação, na praça da República. O grau de 
violência causou indignação em quem presenciou as cenas de brutalidade que foram relatadas nas redes sociais. Dez manifestantes foram presos.(...) O produtor Eugênio Lima, um dos diretores do coletivo de teatro e hip hop, Núcleo Bartolomeu de Depoimentos, faz um relato indignado nas redes sociais sobre um espancamento que ele e alunos que assistiam a uma aula no teatro de Arena Eugênio Kusnet presenciaram. 'Foi uma agressão pura, brutal, e feita de maneira covarde', classificou Eugênio.'Os três jovens adolescentes estavam gritando palavras de ordem, de repente ouvimos muitas sirenes. E eu vi um policial com a motocicleta empurrar um jovem desarmado, sem camisa em cima das grades do banco em frente ao teatro', relata. (...) 'Não, Não e Não. Os garotos não eram black blocs. Os garotos estavam andando e as motos foram atrás deles', contou Eugênio. E completa: 'Depois fiquei pensando sobre o que justifica, um oficial de segurança do estado, com arma, moto, estando em maioria, espancar um garoto aos socos, por que ele o chamou de fascista'. (Portal da CTB: "Polícia de Alckmin reprime com truculência manifestação de estudantes em São Paulo", 10/12/2015)

Essa reportagem é relevante para presente pesquisa por algumas características do acontecido. A (1) primeira é que a manifestação era uma forma de apropriação do espaço público por parte de um grupo de pessoas; a (2) segunda é que a repressão foi uma forma de inviabilizar a apropriação que estava sendo dada ao espaço; ainda, (3) a manifestação estava articulada às ocupações de escolas por estudantes, que se enquadra como uma forma de disputa física sobre o espaço público; e (4) o tema era a "reorganização" do ensino do Estado, que significava deslocar parte dos estudantes de uma escola para outra, o que pode ser entendido como uma disputa política sobre a forma de organização dos espaços públicos.

Ainda, no período, a polícia estava a serviço de Alexandre de Moraes, então Secretário da Segurança de São Paulo, que foi um dos responsáveis pela instalação do projeto Detecta, e que se tornou, mais tarde, Ministro da Justiça do Brasil. Nesse sentido, a reportagem aborda: (a) disputa física sobre o espaço público; (b) disputa política sobre o que deve ser o espaço público; e (c) o uso da força policial como instrumento de garantia da normatização do uso do espaço, em um recorte politizado. Ou seja, aborda a existência de um Estado Policial em construção no Brasil.

O veículo que divulgou a reportagem é um portal de uma central sindical. A CTB, oficialmente, se coloca contra um Estado Policial que acredita estar em construção no Brasil. O próprio veículo, portanto, também se coloca no cambo do embate teórico sobre o espaço público. Parece defender que o espaço público deve ter seus rumos definidos no campo da política, pela população. 
Se a sociedade de controle se faz a revelia de qualquer ente, o Estado Policial é um projeto. Nesse sentido, as figuras públicas que defendem esse projeto, direta ou indiretamente, precisam ser levadas em conta em estudos sobre o tema. Para entender o videomonitoramento no Brasil é importante entender o papel das secretarias de segurança. Destacou-se, em São Paulo, Alexandre de Moraes, então secretário da segurança de São Paulo, que coordenou uma nova etapa do uso de câmeras de segurança em São Paulo, e posteriormente, no Brasil.

Ele parecia não ter problemas com o uso da força policial como instrumento de organização social. Durante as ocupações dos estudantes, o então secretário da segurança utilizou sua polícia para reprimir estudantes, segundo os próprios manifestantes. Reiteradas vezes defendeu o uso da polícia para garantir o "bom funcionamento" das escolas. Ainda, defendeu o uso da polícia para garantir a "o direito de ir e vir" da população, contra o direito de manifestação daqueles que se opunham ao estado.

Curiosamente, a mesma polícia militar de São Paulo, usada para reprimir os estudantes, não teve problemas em servir de segurança para os manifestantes que pediam o impeachment da então Presidenta Dilma. Entre 2015 e 2016, ocorreram diversas passeatas contra a presidenta. Nelas, as passagens de metrôs se tornavam gratuitas, a polícia garantia a defesa dos manifestantes, e os manifestantes louvavam a polícia e a justiça como instrumento regulador do espaço público.

Aqui, há dois elementos relevantes para entender o Estado Policial que parece ser instalado no país: a população é dividida em duas categorias: (a) os aliados ao Estado Policial, que são tratados de modo pacífico, e seu direito ao espaço público é garantido; e (b) os adversários, ou entraves, ao Estado Policial, que são perseguidos e retirados, assim que possível, do espaço que ocupam, apesar de o espaço ser público. Em última instância, o que está em jogo são os projetos e entendimentos do que é o espaço público: quem acha que ele é um espaço a ser mediado e normatizado por forças do Estado, é considerado aliado. Quem se coloca em favor de uma compreensão e uso do espaço público como espaço político, é perseguido.

O uso da Polícia Militar do Estado de São Paulo para reprimir estudantes e manifestantes continuou no período seguinte. Em maio de 2016, o jornal de internet Rede 
Brasil Atual veiculou a reportagem "Apeoesp acusa Alckmin de instaurar Estado policial em São Paulo", onde foi comentada uma nota da presidenta da Apeoesp sobre a violência policial utilizada para retira estudantes de escolas técnicas estaduais e outras unidades escolares.

A reportagem buscou ressaltar a denúncia da então presidenta da Apeoesp, Maria Izabel Azevedo Noronha (Bebel), sobre a Polícia Militar ser utilizada ilegalmente para reprimir manifestantes. Os trechos selecionados na citação acima trazem parte da nota que revela características importantes do ponto de vista da Apeoesp sobre o ocorrido. Por oposição, é possível reconstruir o conflito de ideias entre duas visões sobre o espaço público e o papel da polícia:

\begin{abstract}
'Governo Alckmin instaura estado policial em São Paulo', diz o título da nota divulgada nesta sexta-feira (13) pela presidenta do Sindicato dos Professores do Ensino Oficial do Estado de São Paulo (Apeoesp), Maria Izabel Azevedo Noronha, a Bebel. No texto, ela denuncia e repudia de forma veemente a violência policial ilegal praticada pelo governo do Estado de São Paulo contra os estudantes que ocupavam prédios de escolas técnicas estaduais (Etecs) e outras unidades escolares e diretorias de ensino para reivindicar merenda de qualidade, instalação da Comissão Parlamentar de Inquérito (CPI) para investigar a máfia da merenda e melhores condições de ensino. (...) 'A Polícia Militar não pode ser usada para garantir a posse de algum bem. Ela serve ao cumprimento da lei ou de ordem judicial. O estado possui o monopólio da força. No entanto, isso não autoriza a dispor dela como bem quiser. Deve obedecer à lei, ao poder judiciário e acima de tudo assegurar os direitos humanos', afirma. (...) 'O argumento de que o poder público está exercendo seu direito à propriedade e, por conta disso, não dependeria de ordem judicial é uma falácia. O direito à propriedade tem uma condicionante fundamental: toda propriedade deve atender à sua função social. $A$ reivindicação dos movimentos vai justamente nesse sentido.(...)'. (Rede Brasil Atual: "Apeoesp acusa Alckmin de instaurar Estado policial em São Paulo", 14/05/2016).
\end{abstract}

Um grupo de estudantes de São Paulo, diante da falta de merenda escolar, decidiram ocupar os prédios públicos de escolas onde estudavam. Sua reivindicação era simples: que passasse a ser oferecida merenda escolar. O Estado negociou com os estudantes, mas como não se chegou a nenhum tipo de acordo, os estudantes decidiram permanecer mais tempo nas ocupações.

No dia 13 de maio de 2016, a polícia militar desocupou três diretorias de ensino que haviam sido ocupadas por estudantes. A desocupação foi feita um dia após Alexandre de Moraes deixar de ser secretário de segurança de São Paulo e se tornar o novo 
ministro da justiça do Brasil. A decisão de desocupar as unidades partiu do procuradorgeral do estado de São Paulo, após a consulta a Alexandre de Moraes, segundo reportagem do Jornal $\mathrm{G} 1^{47}$. A desocupação foi feita sem que fosse aprovado na justiça um pedido de reintegração de posse.

Na prática, o poder executivo de São Paulo, após um parecer do ministro da justiça decidiu garantir o funcionamento normatizado de um espaço público, sem consultar o poder judiciário. Enquanto isso, os estudantes entendiam que a ocupação da diretoria era uma forma de garantir sua reivindicação, o que era direito deles, segundo a Apeoesp. $O$ que estava em jogo, novamente, era duas perspectivas sobre o que era o espaço público: (a) um espaço que deveria funcionar segundo as regras escritas anteriormente; ou (b) um espaço da realização da política.

\title{
4.6 ASPECTOS DA SOCIEDADE DE CONTROLE NO BRASIL
}

Dado o baixo nível de consumo e de acesso aos equipamentos públicos que boa parte da população possui, no Brasil a sociedade de controle foi impulsionada pelo Estado. O investimento dos governos em segurança, com desenvolvimento de novas técnicas, levou à formação de uma sociedade de controle repressiva. A modulação das pessoas se dá, em grande medida, através do medo da repressão e das consequências de seus atos.

\begin{abstract}
Segundo o ministro da Justiça, Alexandre de Moraes, as investigações teriam envolvido a interceptação de conversas em aplicativos como Telegram e WhatsApp - apesar de o WhatsApp ter sido bloqueado esta semana por não ter condições de auxiliar as autoridades na investigação de crimes.(...) Existem ao menos quatro métodos de se obter os dados da comunicação do WhatsApp e que não exigem a quebra da segurança do aplicativo em si e nem a colaboração dele para funcionar. São eles: (...) 1. Instalação de vírus no computador ou no celular dos investigados. (...) 2. Obtenção do backup de conversas. (...) 3. Agente infiltrado em grupos. (...) 4. Clonagem do número com colaboração da operadora. (Jornal G1: "Como o governo teria grampeado terroristas no WhatsApp?", 21/07/2016)
\end{abstract}

A reportagem trata da operação "Hashtag" da Polícia Federal, realizada sob

47 Jornal G1: “PM desocupa escolas técnicas e alunos são levados a delegacias”, 13/05/2016 
comando do ministro da justiça Alexandre de Moraes. A operação consistiu na identificação de supostos terroristas ligados ao Estado Islâmico. Ela pode ser utilizada para entender a tênue linha entre o Estado Policial e uma sociedade do controle. $O$ Estado Policial cria mecanismos para vigiar seus cidadãos. Como consequência, diante da hipótese de ser vigiado, os próprios cidadãos se policiam, edificando uma sociedade do controle.

O que chamou a atenção da sociedade, no entanto, foi que a forma de identificar os suspeitos foi através do aplicativo para celular denominado "WhatsApp". Trata-se de um aplicativo de mensagem de texto que utiliza tecnologia de criptografia. O WhatsApp afirma não ter aceso às mensagens trocadas, e costuma não colaborar com a justiça brasileira nas investigações policiais. Então, questionou-se como as informações teriam sido adquiridas pela Polícia Federal. Alexandre de Moraes se recusou a passar essa informação.

$\mathrm{Na}$ reportagem, são discutidos algumas formas que a polícia poderia ter conseguido os dados. Os métodos descritos já são conhecidos por aqueles que se interessam nas ferramentas de controle e segurança: (1) vírus de computador, utilizados para "grampear" computadores e celulares; (2) acesso de backup das conversas em servidores na internet, nas chamadas "nuvens"; (3) infiltração de agentes, mecanismos comumente utilizado pelas polícias ao redor do mundo, e usado no Brasil desde a época do Império; e (4) clonagem do número, e consequente grampeamento da linha. A percepção que essas ferramentas existem, por parte do público dos jornais de larga circulação, levam ao processo de modelamento repressivo. Se grupos clandestinos podem ser vigiados, e se é relativamente fácil obter informações, qualquer um pode ser localizado.

A reportagem de 12/09/2016, do G1, de título "MP investiga presença de capitão do Exército entre manifestantes de SP", demonstra porque o Estado Policial leva a paranoia de uma sociedade de controle. A reportagem conta a história de 26 jovens que foram detidos no dia 04 de setembro de 2016, antes de uma manifestação contra o Presidente Temer. Eles teriam sido vítimas de um agente infiltrado: o capitão do exército William Pina Botelho, de codinome Baltazar Nunes. Baltazar ficou conhecido como "o infiltrado do Tinder", por ter se aproximado do grupo de jovens, que se comunicavam via WhatsApp, 
através do contato com uma das integrantes do grupo. O contato foi feito através de outro aplicativo - o Tinder:

O Ministério Público de São Paulo vai investigar a denúncia sobre a participação de um capitão do Exército infiltrado entre o grupo de manifestantes preso no dia 4, pouco antes de um protesto contra o presidente Temer, em São Paulo. (...) Um dos manifestantes que foi preso no domingo e não quer se identificar confirma a história. E vai além. (...) 'A gente foi enviado direto para o Deic e nesse momento que a gente entrou no camburão para ir, o Balta já não foi junto. $E$ aí no chat que a gente tinha no whatsapp, ele conversando, falou que estavam mandando ele para outra DP porque ele estava com documento falso' (...). No dia seguinte à prisão, a Justiça mandou soltar todos os jovens. O juiz Rodrigo Camargo disse que eles não tinham antecedentes criminais nem intenção de realizar nenhum crime. Ainda segundo o juiz, o Brasil, como estado democrático de direito, não pode legitimar a prisão para averiguação." (Jornal G1: "MP investiga presença de capitão do Exército entre manifestantes de SP", 12/09/2016).

Baltazar sugeriu que os jovens se encontrassem antes da manifestação no Centro Cultural São Paulo. Mas, uma vez reunidos lá, foram interceptados pela polícia militar. Essa, por sua vez, deteve e juntou todos os pertences dos jovens e afirmaram que os itens carregados por eles demonstravam intenção violenta. O caso tomou repercussão, passando nos telejornais. Os jornais El País e Ponte denunciaram a presença do infiltrado. O juiz que cuidou do caso dos 26 detidos denunciou o absurdo da situação, expondo um desacordo entre o ordenamento jurídico de estado democrático de direito e o comportamento do exército e da polícia militar.

O caso é relevante por demonstrar, mais uma vez, a disputa entre aqueles que entendem o espaço público como locus da política, e aqueles que desejam abafar a política e retirá-la do espaço público. Se há um esforço da polícia para garantir que o espaço público seja apropriado dentro das normas de comportamento previamente estabelecidas, ela o faz desrespeitando as leis do próprio país, conforme apontado pelo juiz Rodrigo Camargo. Isso porque o que a polícia estava enfrentando não era um crime, mas sim uma forma de apropriação do espaço. Nessa disputa, a polícia parece disposta a fazer o necessário para defender um projeto de esvaziamento político do espaço.

\footnotetext{
"Assim como Bernardo, Valéria*, de 17 anos, estava na lista dos 26 detidos no Centro Cultural São Paulo dia 4 de setembro deste ano. Ela narra uma cena semelhante. 'Desde que eu fui presa, todo dia uma viatura fica na padaria ao lado do meu cursinho. É um local em que eu vou todo dia e os dois policiais que me
} 
prenderam ficam lá observando tudo. Além disso, quando fui presa dei o endereço da casa da minha mãe, que é em outro município. No dia seguinte fui visitá-la e tinha uma viatura da PM na frente da casa', conta. (...) Mateus* , de 31 anos, milita moderadamente em protestos e pela internet e não tem nenhuma relação com os três primeiros entrevistados desta reportagem. Ele, desde o ano passado, tem notado outro tipo de vigia, a virtual: 'Tenho alguns indícios de que algumas contas minhas na internet estão sendo monitoradas. Percebi que tinham alguns logins na minha conta sendo feitos de outros lugares. O meu Facebook foi acessado em uma cidade em que eu nunca estive que é Franco da Rocha e o meu e-mail foi acessado em Carapicuíba e eu também não tinha estado na cidade naquela data. E tem mais gente sendo acessada de Carapicuíba'. (...) À primeira vista, Franco da Rocha e Carapicuíba são cidades como quaisquer outras, mas o que levanta suspeita em relação ao acesso nas contas de Mateus é que em ambos os municípios há Centros de Inteligência Policial Seccional da Polícia Civil e tais unidades não são comuns em São Paulo (...)" (Revista Vice: "Manifestantes se dizem perseguidos pela polícia de SP", 18/10/2016)

Aqueles que sofreram perseguição policial passaram a se ver em uma trama de vigilância. Isso que demonstra a reportagem da revista Vice, de onde o trecho acima foi retirado. A reportagem traz a entrevista de dois jovens que estava entre os 26 presos por conta da infiltração de Baltazar, da mãe de um jovem preso, e um quarto militante que não estava no grupo.

O relato dos entrevistados aponta pontos em comum: todos entrevistados pela Vice passaram a se preocupar com a possibilidade de estarem sendo vigiados. Os relatos envolvem viaturas da polícia vigiando locais que eles costumavam ir, e até perseguição policial em espaços públicos. No caso de um dos entrevistados, Mateus, há indícios que suas contas de internet foram monitoradas pela polícia.

Seja a perseguição realmente existente, seja ela uma projeção dos medos dos entrevistados, o que se verifica é o efeito da sociedade de controle. Diante da experiência de vigilância passada, os indivíduos passaram a se sentir vigiados o tempo todo (e provavelmente o são). O espaço público, para eles, deixou de ser um espaço onde eles poderiam participar livremente da vida política e se tornou o locus da vigilância e do medo. Da apropriação livre, o espaço se tornou o locus da perseguição em nome do controle normatizador, aos olhos dos perseguidos. 


\title{
4.7 ASPECTOS DA RESISTÊNCIAS À SOCIEDADE DE CONTROLE
}

A vigilância quase total cria, na população, uma espécie de paranoia. Qualquer um pode se sentir vigiado, a qualquer instante. Essa sensação é tratada com estranheza e com asco por certas camadas. Diante de mecanismos que fornecem o "big data" de cada cidadão, algumas pessoas visam se defender. Tentam retomar o anonimato que thes foi roubado.

A busca por retorno a privacidade, mesmo em público, significa a luta contra a normalização e modulação total da sociedade. Ainda, é também a luta contra um Estado Policial que usa os instrumentos de controle para perseguir costumes e direitos. Essa luta é travada toda vez que um cidadão tenta inviabilizar a vigilância.

\begin{abstract}
A quantidade de radares vandalizados na cidade de São Paulo quase quadruplicou entre 2014 e 2015. O número de equipamentos danificados saltou de 38 para 145 , o que equivale a uma alta de $281 \%$. (...) De acordo com a CET, esses números abrangem todo ato de vandalismo praticados contra os radares, como pichações nas lentes das câmeras e a quebra do equipamento. (...) $\mathrm{Na}$ avaliação do especialista em segurança pública Jorge Lordello, parte desses casos de vandalismo pode estar relacionada à possível ação de 'motoristas revoltados' com a aplicação de multas de trânsito.(...) De acordo com ele, outro fator que pode ter influenciado essa alta é a ação de vândalos, histórica na cidade de São Paulo, contra o patrimônio público. 'Sempre houve muitas ocorrências de dano ao patrimônio público em São Paulo. É uma ação praticada por jovens, que atuam em grupos, e praticam vandalismo, como a destruição de orelhões e a pichação de prédios públicos. Eles podem ter se interessado em destruir os radares'. (Notícias Uol: "Número de radares danificados por vândalos quase quadruplica em São Paulo", 18/02/2016)
\end{abstract}

Os trechos acima foram retirados de uma reportagem do Notícias Uol, da data de 18 de fevereiro de 2016. A notícia aponta o aumento do número de depredações de radares de trânsito entre 2014 e 2015. Enquanto o número de radares instalados na capital aumentou apenas $38 \%$, no período, o número de depredações aumentou $281 \%$.

Um especialista consultado pela equipe do Uol apresentou duas possibilidades: (a) das depredações serem fruto da ação de motoristas raivosos com as multas de trânsito; ou (b) ser fruto de delinquência juvenil. Ele deixou de fora a possibilidade de (c) ser fruto do crime organizado, que podia estar se defendendo da Operação Radar, em vigor na época. 
Seja qual das três alternativas fosse a maior responsável pelo número de depredações, o resultado para análise que interessa aqui é o mesmo. Integrantes da população destruíram ou inviabilizaram um número crescente de instrumentos de monitoramento, na mesma época que a capacidade de vigilância da polícia cresceu pelo novo uso dado aos instrumentos.

Trata-se de uma ação direta que visa bloquear a capacidade das instituições públicas que objetivam fazer valer as normas de utilização do espaço público. A disputa pelo espaço é uma via de mão dupla. Ao passo que a polícia aumentou sua capacidade de controle, parte daqueles que poderiam vir a ser alvo do controle buscaram sabotar a capacidade da polícia.

A disputa pelo espaço pressupõe o confronto de entendimentos de como o espaço deve ser utilizado e organizado: se desde cima, com o uso de aparatos de repressão, ou se comunitariamente, a partir do uso prático dado pela população. Essa disputa pode se dar de forma consciente, ou cotidianamente. Pode ser fruto de uma ação política, ou de disputa entre a polícia e o crime organizado. Processos similares ocorreram em outras cidades, como Taubaté, onde uma pessoa chegou a fazer um motorista de caminhão de lixo de refém para derrubar câmeras de segurança; e um grupo de jovens implantou bombas em postes para derrubar o aparato de monitoramento eletrônico. Em Santa Catarina, onde as câmeras de segurança foram utilizadas para monitorar passeatas contra o governo, desde 2013 a população vêm destruindo equipamento de captura de imagens instaladas em espaço público ${ }^{48}$.

Valter Foleto Santin, Henrique Hoffmann Monteiro de Castro, e Rogério Cangussu Dantas Cachichi, redigiram um artigo de opinião para revista Conjur onde discutiam o direito do cidadão em ter acesso a imagens de câmeras públicas de segurança. A discussão sobre o tema resultou da classificação desse tipo de imagens como sigilosa por parte da prefeitura de São Paulo, na gestão Fernando Haddad. Após a divulgação e a polêmica que se deu na mídia, a classificação foi mantida apenas para as imagens que envolvessem investigações em andamento:

48 Sobre a destruição de câmeras em Taubaté ver: http://videos.bol.uol.com.br/video/vandalos-usam-caminhao-delixo-para-quebrar-camera-de-seguranca-em-sp-04024C193460C8915326, última visualização em 17/08/2016; sobre a destruição de câmeras em Santa Catarina ver: http://ndonline.com.br/florianopolis/coluna/helio-costa/vandalosdestroem-30-cameras-de-vigilancia-em-santa-catarina, última visualização 17/08/2016 
Foi noticiado aqui na ConJur e em outros veículos de comunicação a polêmica providência tomada pela Prefeitura de São Paulo. Consistiu em decretar o sigilo das imagens de câmeras de segurança instaladas pelo Poder Público, com base na Lei de Acesso à Informação (Lei 12.527/11), por supostamente ferir a "individualidade". A informação foi classificada como reservada, grau de sigilo cujo prazo máximo atinge cinco anos (artigo 24 , parágrafo $1^{\circ}$, inciso III da Lei 12.527/11). Depois da repercussão do caso, o Prefeito voltou atrás em sua decisão. (...) o direito fundamental à informação pública, umbilicalmente ligado ao postulado da publicidade, é garantia do cidadão contra o Leviatã. Qualifica-se como importante direito para a concretização da sociedade aberta do futuro, em sua vertente de máxima universalidade, com grande envergadura no panorama das liberdades públicas. (...) Nesse diapasão, o fornecimento de imagens captadas por equipamentos públicos em locais públicos, atendendo a solicitação motivada, não tem o condão de 'criar uma tirania sobre a intimidade do indivíduo'. (Revista Consultório Jurídico, seção de opinião: "Cidadão tem o direito de obter imagens de câmeras públicas de segurança"; 26/10/2015)

O debate sobre o acesso as informações, em específico às imagens de câmeras de segurança, tem significado na disputa sobre o controle do espaço público. Quando sigilosos, apenas a polícia, e outros órgãos do Estado, possuem acesso às informações contidas. Isso significa ter o monopólio da informação. Só ela pode averiguar e mapear os pontos de conflito. Só ela pode estudar os desrespeitos as normas. E ela mesma fica protegida para desrespeitar a lei em nome da "ordem". A polícia, sem ser vigiada, pode forjar flagrantes, espancar inocentes, e dominar a cidade.

Ao menos, essa é a tese defendida pelos autores do artigo supracitado. É isso que eles querem dizer quando afirmam que o acesso à informação e o postulado da publicidade (aqui o termo significa "fazer a informação circular e se tornar efetivamente pública") são ferramentas de defesa contra o Leviatã do Estado. O que separa uma sociedade de Estado Democrático de Direito de um Estado Policial é a capacidade que os cidadãos possuem de se defender da própria polícia, que pode, a qualquer momento, se tornar uma força política.

A luta pelo acesso universal à informação é, dessa forma, uma luta pelo direito ao espaço público. Ainda, confronta a visão privatista do espaço. Para os defensores do sigilo das imagens das câmeras de segurança, divulgar as informações significa invadir a privacidade (ironicamente, o Estado já invadiu a suposta privacidade ao gravar os cidadãos). Para os defensores da difusão da informação, o que é feito no espaço público, é de domínio público. $O$ que está por trás dessas duas concepções é a própria definição 
do que é esse espaço público. Para aqueles que acham que ele é apenas um local por onde as pessoas passam, ou onde as pessoas consomem produtos advindos da esfera privada, o que as pessoas fazem ali é de cunho privado. Para os que acham que ele é o locus da política, o que é feito ali é da esfera pública.

\begin{abstract}
Um vídeo divulgado neste sábado (9) mostra um policial militar colocando objetos supostamente encontrados em um poste na Praça Roosevelt, no Centro de São Paulo, dentro da mochila de um manifestante detido na noite desta sexta-feira (8) no ato contra o aumento da tarifa do transporte público. O material seria um explosivo feito com recipientes de desodorante. (...) A Secretaria da Segurança Pública informou, por meio de sua assessoria de imprensa, que não há indícios de má conduta por parte policiais militares. A pasta aguarda as imagens sem edição para se posicionar. A pasta diz ainda que 'todas as ações são filmadas pela própria PM, que apresentou no $78^{\circ}$ Distrito Policial imagens que mostram o suspeito detido atirando um artefato explosivo contra as viaturas e agentes de segurança que estavam no local'. (Jornal G1: "Vídeo mostra PM colocando objetos em mochila de manifestante em SP", 09/01/2016)
\end{abstract}

O confronto pelo espaço passa também pela luta pelo reconhecimento da legitimidade do uso dado ao espaço público. Quando o conflito se transforma em escaramuça de rua, segue a ela uma disputa dos lados envolvidos para legitimar suas próprias ações. As imagens coletadas são instrumento chave para isso. Os trechos acima permitem captar um aspecto dessa disputa.

A reportagem de qual foram tirados os trechos supracitados trata de prisões realizadas após o ato dos dias 08 de janeiro de 2016. O ato foi realizado contra o aumento da tarifa do ônibus para $R \$ 3,80$. Segundo a $P M$, o ato segui pacífico, até que um grupo de vândalos começou a depredar patrimônio e a jogar objetos na polícia. Segundo os manifestantes, o ato seguia pacífico, até que a polícia jogou bombas de gás, iniciando um tumulto. Todas as imagens coletas pela mídia de manifestantes depredando patrimônio (público ou privado), e confrontando a polícia são de depois do início do conflito.

A reportagem aborda uma prisão em específico, realizada na praça Roosevelt. A abordagem da polícia foi filmada por cinematógrafos amadores, e passada para o site Jornalistas Livres. Nas imagens, um policial militar coletou material que estava no chão, longe dos manifestantes, e, enquanto eles estavam distraídos, colocou na mochila de um dos suspeitos. Esse mesmo material, plantado na mochila, serviu de desculpas para deter 
os manifestantes. A imagem demonstra claramente um procedimento de perseguição, 0 que categoriza a repressão como a tentativa de eliminação pontual do direito ao protesto.

Por outro lado, a secretaria de segurança afirma que tem filmagens daqueles suspeitos depredando patrimônio e atacando policiais. Essas imagens não foram divulgadas publicamente. Mas, segundo a polícia, elas existem. Caso se acredite que a polícia que forja flagrante não mente sobre possuir ou não outras evidências, o que se verifica é uma guerra de informação utilizando duas filmagens de momentos diferentes.

A população não possui acesso às imagens gravadas em manifestações, quando ocorre conflito. Isso porque, ao envolver um processo em andamento, elas são consideradas sigilosas. Para se defender (judicialmente), os manifestantes só podem argumentar contra as imagens coletadas apresentando outras imagens que contradigam a história contada pela polícia.

Nesse sentido, a atuação de jornalistas independentes, e de cinematógrafos amadores é uma forma da população montar sua própria base de dados a ser utilizada para vigiar e desmentir a polícia que utiliza (arbitrariamente) o "big data". A disputa física pelo espaço público passa pela disputa teórica do mesmo, e também pela disputa informacional.

A chamada guerra de informações é um dos diversos temas do estudo da guerra e do conflito. Saber esclarecer suas intenções, e denunciar os exageros e erros de seus adversários, faz parte a arte da guerra. Como consequência, a informação, o conhecimento, e a propaganda possuem seu impacto sobre a conquista e gestão do espaço. Se informar e ter opinião sobre o que está acontecendo em dado espaço público é, também, se apropriar dos mesmos. Cada vez que a população se coloca ao lado das forças institucionais que defendem o uso normativo do espaço, se aproxima de uma apropriação asséptica do espaço público. Cada vez que se aproxima dos grupos e movimentos que buscam outra forma de socialização, que não a atualmente normatizada, se apropria do espaço público como locus do debate e da discussão. Isso é um exemplo do caráter heterotópico do espaço público: a luta pelos símbolos faz com o próprio espaço não possa ter sua função definida de forma estanque por boa parte da população. 


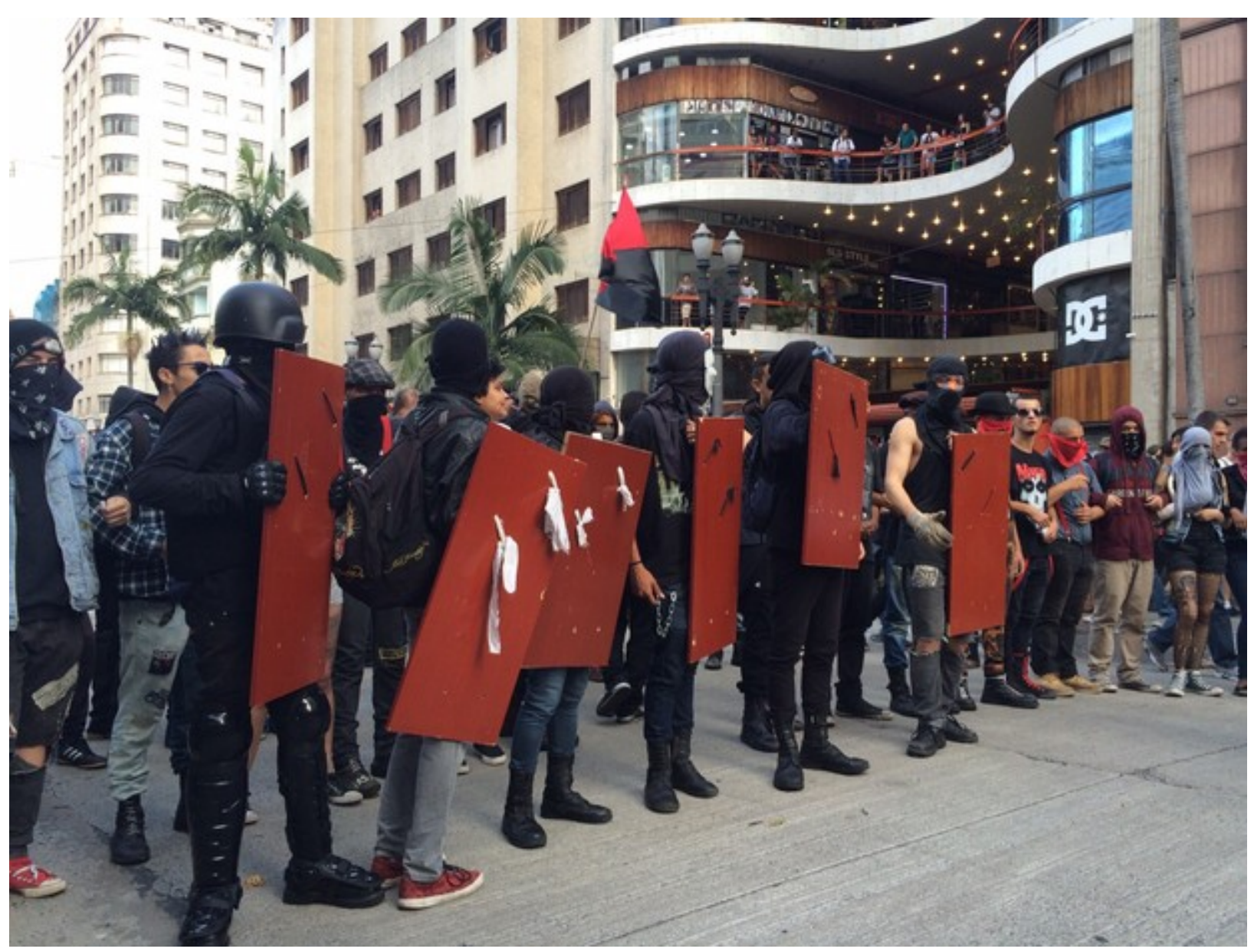

(Foto: Glauco Araújo/G1)

A mesma reportagem do $\mathrm{G} 1$ traz uma série de imagens da passeata e dos confrontos entre a polícia e manifestantes ou transeuntes. A foto acima é a de manifestantes mascarados que formaram a linha de frente do ato. No momento da foto, eles estavam na frente da Galeria do Rock (Av. São João, 439, República).

A principal forma que manifestantes políticos, e artistas que realizam intervenções não autorizadas na cidade, possuem de se defender do uso do "big data" para criminalizálos (arbitrariamente ou não), é o anonimato. O uso de máscaras, óculos e bonés, e pinturas de rosto é uma forma de dificultar a identificação através do videomonitoramento e do uso de bancos de dados.

Essa forma de dificultar a identificação chegou a preocupar as autoridades brasileiras em 2013. O congresso nacional chegou a discutir a proibição do uso de máscaras em protestos. Em São Paulo, desde 2014, a câmara estadual aprovou uma lei proibindo o anonimato em protestos. No entanto, o governador Alckmin optou por não 
sancionar a lei, a encaminhado para uma comissão técnica que, até 2016, ainda não havia dado parecer. A lentidão do governador de São Paulo se explica pelo fato do congresso nacional discutir uma lei similar, a Proposta de Lei 5964/13. Ela foi aprovada pela comissão de segurança da câmera, mas até 2018, ainda não havia o parecer do relator da comissão de constituição, de justiça e de cidadania da câmara.

A PL 5964/13 proíbe o uso de objetos ou substâncias que dificultem a identificação do usuário em lugar público. Não afeta apenas passeatas e eventos culturais, mas sim a todos que utilizam os espaços públicos cotidianamente. Na prática, se aprovada, seria a proibição aos cidadãos de tentar escapar ao "cerco eletrônico" dos espaços públicos. 


\section{CONSIDERAÇÕES FINAIS}

Neste trabalho buscamos refletir acerca da seguinte questão: o projeto Detecta foi um instrumento de controle que impactou na apropriação do espaço público da cidade de São Paulo?. Partimos da hipótese central que o Detecta funcionou como uma peça de propaganda de guerra psicológica em favor da normatização do espaço público. O que colocava em jogo seria menos a diminuição da incidência de indicadores criminais (assaltos, assassinatos, sequestros etc.) do que propriamente a diminuição do sentido político do espaço público em si. A própria distribuição das câmeras na área central da cidade já apontava para esta tendência, negligenciando as áreas periféricas de maior incidência criminal.

Falar em guerra psicológica no contexto urbano significa dizer que, para os gestores da segurança pública de São Paulo na atualidade, a cidadania exercida no espaço público deve ser coibida por meio de diferentes estratégias. Em parte, o cidadão que exerce o seu direito à manifestação cumpre papel mais ameaçador à ordem estabelecida do que agentes marginais, sejam estes criminosos ou terroristas. A associação entre manifestação política e comportamento infrator revela um mecanismo de controle que preserva a fluidez do sistema econômico em detrimento do teste cotidiano que a rua poderia fazer frente à atividade política.

Não intentamos esgotar esse debate sobre o detecta e sobre o controle do espaço público. Mas tentamos realizar apontamentos que facilitem uma leitura da relação entre os instrumentos de controle e as forças de segurança, no escopo da disputa pelo subjetivo e pela narrativa como ferramenta de territorialização do espaço público. Nesse sentido, tratamos o detecta como um caso para entender como a guerra psicológica serve a disputa política pelo espaço urbano em um contexto de uma sociedade do controle.

A chave de interpretação que propusermos passa pela divisão dos distintos grupos que disputam o espaço público em dois conjuntos distintos: de um lado estão aqueles que acreditam na utopia do espaço público como um espaço da política e, portanto, passível de uma apropriação orgânica. Do outro, aqueles favoráveis a utopia da assepsia do espaço e, portanto, favoráveis ao controle normativo das relações sociais. O que, em 
última instância significa manter a política fora do espaço público.

A forma pela qual se implementa a utopia da assepsia é através da formação de um território humano, conforme o conceito de Sack, onde os grupos sociais considerados nocivos a norma tem a sua atuação e presença limitada. A formação desse território depende também da adoção de uma arquitetura de guerra, conforme proposto por Graham.

Essa arquitetura cria limitações físicas para a livre apropriação, através do policiamento ostensivo, criação de guaritas, etc. Mas, também, tem um impacto subjetivo na população. Ao mesmo tempo cria uma sensação de segurança para os favoráveis a assepsia do espaço e uma paranoia nos grupos que lutam pela apropriação orgânica do mesmo.

Nota-se que não se trata apenas de disciplinarizar os indivíduos que potencialmente transitariam nesse espaço público. Na verdade, ocorre uma modelação da população, onde os agrupamentos perseguidos assumem o papel de inimigo público, criado pelas forças de segurança. Uma vez decretado como inimigo, os agentes sociais desse grupo podem passar a se comportar como tal, evitando o território das forças de segurança, a não ser que para realizar um conflito.

A relação entre o sistema detecta e a modelação da sociedade, na criação de territórios, passa por entender os instrumentos de produção de inimigos a serem perseguido. Não é natural, tão pouco automático, que movimentos dos sem teto, movimentos pelo direito ao transporte e o movimento estudantil sejam vistos como nocivos ao livre uso do espaço público.

$\mathrm{Na}$ verdade, esses movimentos, quando analisadas as pautas por eles defendidas, lutam por um espaço público mais democrático. Ainda assim, são retratados pela mídia e tratados pela polícia como disruptores da ordem pública e do direito de ir e vir. Tal situação não é, infelizmente, uma hipótese remota no contexto da América Latina: ao longo do século $\mathrm{XX}$, trata-se de um fato a mobilização de aparelhos midiáticos para fins de controle político. Diversos grupos midiáticos latino-americanos realizaram mea culpa no final do século XX sobre o papel cumprido no contexto dos regimes de exceção em seus respectivos países, tal qual a Rede Globo de televisão realizou em 2013. O que está 
em debate, então, é uma questão da intensidade e dos tipos de controles exercidos por estes novos arranjos de controle entre Estado e grupos privados.

Ao longo dessa dissertação, refletimos teoricamente sobre esse assunto, exemplificamos com alguns casos e utilizamos notícias de jornal. Os casos de perseguição ao MPL e ao MTST em São Paulo estão ligados de forma bastante clara ao uso do videomonitoramento e a criação de bancos de dados de pessoas de interesse. Está claro para esses grupos também que, se o Estado os trata como inimigos, eles não podem confiar nas forças de segurança. A progressão das tecnologias para que, de fato, possam realizar a função de reconhecimento facial e análise inteligente, prévia à interpretação humana, tende a oferecer as condições para um controle mais sistemático no futuro.

Essa disputa pelo espaço, como demonstramos, passou por uma disputa pela informação. Embora possamos afirmas que a mídia tende a ser favorável as forças policiais, quando se trata do controle territorial sobre o espaço público, vimos que essa relação é menos harmônica do que se faz parecer. No caso do Detecta, a propaganda oficial feita pela secretaria de Segurança Pública de São Paulo só foi integralmente aceita pelos pequenos jornais locais ou de grupos sociais específicos: jornal dos delegados, algumas associações de moradores, etc.

A grande mídia, representada pelos principais jornais do estado de São Paulo, tratou com desconfiança o Detecta. No entanto, o discurso feito por esses grandes jornais, ao tratar sobre movimentos sociais, foi sempre condizente com a política de demonização do adversário. Isso indica que órgãos de mídia podem participar, direta ou indiretamente, da operação psicológica para a disputa do espaço público urbano, sem aceitar peças de propaganda específicas da referida operação.

O que tiramos de conclusão dessa leitura é que o possível papel das operações psicológicas da disputa do espaço público é de unificar o ódio contra os agrupamentos que resistem ao projeto oficial previamente elaborado para a cidade. Dissemina o terror, a paranoia e o incomodo para justificar a adoção da arquitetura de guerra que, ironicamente, é justamente o que amplia a vontade de resistência dos agrupamentos considerados incômodos pelo Estado. 
No caso de São Paulo, o videomonitoramento e a propaganda vem criando um cerco, especialmente no centro expandido. Ali temos uma disputa assimétrica, onde as forças favoráveis a assepsia do espaço utilizam todos os meios possíveis para impor sua vontade.

Enquanto isso, os grupos que tentam resistir estão desorganizados, possuem poucos meios para difundir informação e sempre que buscam o confronto direto, se veem diante de uma força policial que possui o monopólio da violência e o apoio da maioria dos meios de comunicação.

Durante os anos analisados, de 2014 a 2018, observou-se um esforço mais aguerrido para a realização de movimentos de resistência política, inclusive com tentativa de unificação dos distintos movimentos. No mesmo período, houve perseguição sistemática as lideranças que começavam a surgir, perseguição realizada principalmente pleas forças policiais e pela mídia.

A reflexão que queremos apontar é que, na prática, o esforço pela instauração da utopia da assepsia coincide com a instalação de uma distopia da sociedade do controle conforme proposto por Deleuze e Guatarri: a instituição de uma cidade onde para uma pessoa sair de seu apartamento, rua ou bairro ela precisa apresentar um cartão que the permite ultrapassar as barreiras de controle. Esse cartão limita o acesso das pessoas a certos locais, em certos horários, a depender de sua identidade social. O que está por trás dessa distopia é a existência de um sistema computacional que registra as atividades das pessoas, criando uma modulação universal sobre a apropriação da cidade (Deleuze, 1992). 


\section{BIBLIOGRAFIA}

ADORNO, Sérgio. Discriminação racial e justiça criminal em São Paulo. In: Novos estudos CEBRAP, v. 43, p. 45-63, 1995.

ALUBO, Ogoh. The Public Space in Nigeria: Politics of Power, Gender and Exclusion. Africa Development / Afrique et Développement, Vol. 36, 2011, No. 1.

ARENDT, Hannah. A condição humana. Rio de Janeiro: Forense-Universitária, 1983 [1958].

BARBOSA, Wilson do Nascimento. Formas de Luta e Estratégia. In Mouro: revista marxista. São Paulo: IDEO graphos, nº 3, ano 2, p. 7 a 18, Julho de 2010.

BARBOSA, Wilson do Nascimento. História Cultural e Etnicidade Negra. São Paulo: USP, 1989.

BERNSTEIN, Alvin H. "Political Strategies in Coercive Diplomacy and Limited War". in: LORD, Carnes \& BARNETT, Frank R. (Ed.). Political Warfare and Psychological Operations: Rethinking the US Approach. Nova lorque: National Defense University Press \& National Strategy Information Center, 1989.

CODEVILLA, Angelo M. Political Warfare. In: LORD, Carnes \& BARNETT, Frank R. (Ed.). Political Warfare and Psychological Operations: Rethinking the US Approach. Nova lorque: National Defense University Press \& National Strategy Information Center, 1989.

CUNHA JUNIOR, Henrique. Racismo antinegro, um problema estrutural e ideológico das relações sociais brasileiras. In: Política Democrática: Revista de Política e Cultura. Brasília Fundação Astrogildo Pereira, ano VII, n. 21, p. 118-127, 2008.

DEE, Hannah M.; VELASTIN, Sergio A. How close are we to solving the problem of automated visual surveillance?. Machine Vision and Applications, v. 19, n. 5-6, p. 329-343, 2008.

DELEUZE, Gilles. Postscript on the Societies of Control.In: October, v. 59, p. 3-7, 1992.

DO RIO CALDEIRA, Teresa Pires. Cidade de muros: crime, segregação e cidadania em São Paulo. Editora 34, 2000

FIRMINO, Rodrigo. Connected and controlled: surveillance, security and cities. In: Landscape Architecture, Abril 2016.

FIRMINO, Rodrigo \& DUARTE, Fábio. Manifestations and implications of an augmented urban life. In: International Review of Information Ethics (IRIE), vol. 12 (03\2010). P. 28-35.

FIRMINO, Rodrigo \& DUARTE, Fábio. Private video monitoring of public spaces: The construction of new invisible territories. In: Urban Studies, Janeiro 2015. Vol. 53 (4). 


\section{p. 741-754.}

FORESTI, Gian Luca; MÄHÖNEN, Petri; REGAZZONI, Carlo S. (Ed.). Multimedia videobased surveillance systems: Requirements, Issues and Solutions. Springer Science \& Business Media, 2012

GARLAND, David. The Culture of Control. Oxford: The University of Chicago Press, 2002.

GOMES, Paulo César da Costa. A Condição Urbana - Ensaios de Geopolítica da cidade. Bertrand Brasil, 2002.

GRAHAM, Stephen. Cities under siege: the new military urbanism. Londres: Verso, 2011.

GUIMARÃES, Antonio Sérgio Alfredo. Preconceito de cor e racismo no Brasil. In: Revista de antropologia, v. 47, n. 1, p. 9-43, 2004.

GUIMARÃES, Antonio Sérgio Alfredo. Tirando a máscara: ensaios sobre o racismo no Brasil. Paz e Terra, 2000.

HABERMAS, Jurgen. Mudança estrutural da esfera pública. Rio de Janeiro: Tempo brasileiro, 1984 [1964].

HARDT, Michael \& NEGRI, Antonio. Empire. Cambridge: Havard university Press, 2000

HUGGINS, Martha K. Polícia e política: relações Estados Unidos, América Latina. Cortez, 1998.

HOFFMAN, Frank G. Conflict in the 21st century: The rise of hybrid wars. Arlington: Potomac Institute for Policy Studies, 2007.

IKLE, Fred C. "The Modern Context". in: LORD, Carnes \& BARNETT, Frank R. (Ed.). Political Warfare and Psychological Operations: Rethinking the US Approach. Nova lorque: National Defense University Press \& National Strategy Information Center, 1989.

KATZ, Cindi. "Power, Space, and Terror: Social Reproduction and the Public Environment". In: LOW, Setha \& SMITH, Neil (orgs.) The Politics of Public Space. Nova lorque: Routledge, 2006.

KELLY, Mark G. E. Discipline is Control: Foucault contra Deleuze. In: New formations: a journal of culture/theory/politics, Volume 84-85, 2015.

LAZZARATO, Maurizio. "The Concepts of Life and the Living in the Societies of Control". In: FUGLSANG, Martin \& SORENSEN, Bent Meier (org). Deleuze and the Social. Edinburgo: Edinburgh University Press, 2006.

LAZZARATO, Maurizio. Signs and machines: capitalism and the production of subjectivity. Los Angeles: Semiotexte, 2014.

LEFEBVRE, Henri. O Direito à Cidade. Editora Moraes: São Paulo, 1991 [1969]. 
Lind, William S. et al. "Tha changing face of war: into the fourth generation" in:. KARP, Aaron et al. (Ed.). Global Insurgency and the Future of Armed Conflict: Debating fourth-generation warfare. Routledge, 2010.

LORD, Carnes. "The Psychological Dimension in National Strategy". in: LORD, Carnes \& BARNETT, Frank R. (Ed.). Political Warfare and Psychological Operations: Rethinking the US Approach. Nova lorque: National Defense University Press \& National Strategy Information Center, 1989.

LOWMAN, John. Conceptual Issues in the Geography of Crime: Toward a Geography of Social Control. In: Annals of the Association of American Geographers, Vol. 76, No. 1 (Mar., 1986).

MCDOWELL, Meghan G. \& WONDERS, Nancy A. Keeping Migrants in Their Place: Technologies of Control and Racialized Public Space in Arizona. In: Social Justice, Vol. 36, No. 2 (116), Policing, Detention, Deportation, and Resistance (2009-2010).

MELGAÇO, Lucas. Securização Urbana: da psicoesfera do medo à tecnoesfera da segurança. Tese (Doutorado), Faculdade de Filosofia, Letras e Ciências Humanas da Universidade de São Paulo. São Paulo, 2010.

MITCHELL, Don. The right to the city: social justice and the fight for public space. London: Guilford Press, 2003 [2003].

NUNES, Samira Bueno. TRABALHO SUJO OU MISSÃO DE VIDA? Persistência, reprodução e legitimidade da letalidade na ação da PMESP. São Paulo: Fundação Getúlio Vargas, 2018.

OLIVA, Diego Coletti. "Se eu grito e o governo não escuta...Vamos quebrar": a instrumentalização política da violência a partir da atuação da tática black bloc no Brasil pós junho de 2013”. Curitiba: Universidade Federal do Paraná, 2017.

PADDOCK JR., Alfred H. "Military Psychological Operations". in: LORD, Carnes \& BARNETT, Frank R. (Ed.). Political Warfare and Psychological Operations: Rethinking the US Approach. Nova lorque: National Defense University Press \& National Strategy Information Center, 1989.

QIAO, Liang; WANG, Xiangsui. Unrestricted warfare. PLA Literature and Arts Publishing House Arts, 1999.

RAMONET, Ignacio. Geopolitic of Chaos. Nova lorque: Algora Publishing, 1998.

RAMONET. Ignacio. "Meios De Comunicação: Um Poder A Serviço De Interesses Privados?" in: MORAES, Denis de; RAMONET, Ignacio; SERRANO, Pascual. Mídia, poder e contrapoder. Da concentração monopólica à democratização da informação. São Paulo: Editora Boitempo, 2013.

RAMONET, Ignacio. El imperio de la vigilancia. Buenos Aires, Capital Intelectual, 2016.

ROSE, Nikolas. Government and control. In: The British Journal of Criminology, Vol. 40, No. 2, Special issue: criminology and social theory (spring 2000). 
SACK, Robert D. Human Territoriality: A Theory. In: Annals of the Association of American Geographers, Vol. 73, No. 1. (Mar., 1983), pp. 55-74.

SCHLEIFER, Ron. Psychological Warfare in the Arab-Israeli Conflict. Nova lorque: Palgrave Macmillan, 2014.

SENNETT, Richard. O declínio do homem público: as tiranias da intimidade. São Paulo: Companhia das Letras, 1988 [1943].

SIMONS, Greg. Fourth Generation Warfare and The Clash of Civilizations.In: Journal of Islamic Studies, v. 21, n. 3, p. 391-412, 2010. Pg. 398.

SIMPSON, Christopher. Science of Coercion: Communication Research \& Psychological Warfare, 1945 - 1960. Open Road Media, 2015.

SOUZA, Marcelo Lopes de. Fobópole: o medo generalizado e a militarização da questão urbana. Rio de Janeiro: Bertrand Brasil, 2008.

VALVERDE, Rodrigo R.H.F. $\boldsymbol{A}$ transformação da noção de espaço público: a tendência à heterotopia no Largo da Carioca. Tese de Doutorado do Programa de Pós-Graduação em Geografia. Rio de Janeiro: UFRJ/IGEO/PPGG, 2007.

VERISSIMO, Rafael da Silva. Espaço público e segurança pública: duas abordagens teóricas de prevenção do crime e da violência. Dissertação de Mestrado do Programa de Pós-Graduação em Urbanismo. Rio de Janeiro: UFRJ/FAU, 2012.

ZAMORA, Maria Helena Rodrigues Navas. Desigualdade racial, racismo e seus efeitos. In: Fractal: Revista de Psicologia, v. 24, n. 3, p. 563-578, 2012.

XU, Li-Qun. Issues in video analytics and surveillance systems: Research/prototyping vs. applications/user requirements. In: Advanced Video and Signal Based Surveillance, 2007. AVSS 2007. IEEE Conference on. IEEE, 2007.

WILLIAMSON, Steven C. From Fourth Generation Warfare To Hybrid War. Pensilvânia: US. Army War College, 2009.

\section{Notícias e Reportagens:}

A Tribuna: "Nova etapa do Detecta entra em operação para monitorar crimes", 12/08/2014

A. Pública: "O Inquérito do Black Bloc", 28/02/2014

A. Pública: "Meu nome não é Sininho", 13 de Abril de 2017

Al Jazeera: "Trump's War on Gangs", 11/04/2018

Band News: "Câmeras de segurança podem ajudar a identificar vândalos", 02/11/2015

Brasil 24/7: "Mesmo em teste, Detecta ajudou a coibir caos em SP", 17/09/2014 
Diário de São Paulo: “Detecta começa a ajudar a polícia”, 14/08/2014

Folha de São Paulo: "Coronel da PM ajudou multinacional a vender Detecta para governo Alckmin", 04/10/2014

Folha de São Paulo: "Promessa eleitoral contra crime em SP emperra, e Alckmin recorre à PM", 08/05/2015

GGN: "Secundaristas são perseguidos e espancados por PMs em SP". 01/11/2016

Jornal da Band: "Professor acusado de ser black block é preso", 24/07/2014

Jornal G1: "Vídeo mostra PM colocando objetos em mochila de manifestante em SP", $09 / 01 / 2016$

Jornal G1: "Governo de SP quer integrar câmeras de condomínios à Polícia Militar", $12 / 07 / 2016$

Jornal G1: "Como o governo teria grampeado terroristas no WhatsApp?", 21/07/2016

Jornal G1: "Câmera registra casal pichando o Monumento às Bandeiras, em SP", $30 / 09 / 2016$

Jornal G1: "MP investiga presença de capitão do Exército entre manifestantes de SP", $12 / 09 / 2016$

Jornal G1 São Paulo: "Doria sanciona lei que penaliza pichadores com multa", 20/02/2017.

Jornal G1: Alckimin regulamenta lei que proíbe pancadões no Estado de São Paulo, $16 / 03 / 2017$

O Estado de São Paulo: "Pista de skate da Praça Roosevelt é pichada 24h depois de inauguração", 04/12/2014

O Estado de São Paulo: "Após 2 anos, sistema Detecta da polícia não identifica crimes, diz TCE", 13/08/2016

O Estado de São Paulo: "Sistema de vídeo contra crime ainda é falho, diz TCE", 29/04/2017.

O Globo: "Apoio editorial ao golpe de 1964 foi um erro", 31/08/2013]

O Globo: "Alckmin diz que vândalos foram responsáveis por ação no metrô", 05/02/2014

Portal da associação dos oficiais da polícia militar: "Secretário da Segurança Pública apresenta usos do Detecta", 23/09/2015

Portal da CTB: "Polícia de Alckmin reprime com truculência manifestação de estudantes em São Paulo", 10/12/2015

Portal do Sindicato de Habitação de São Paulo: "Detecta vai integrar radares da Prefeitura para aumentar segurança na Capital”, 08/08/2016) 
Portal do Governo: "Sistema Detecta ganha 97 novas câmeras de monitoramento", 18/10/2016.

Rede Brasil Atual: "Apeoesp acusa Alckmin de instaurar Estado policial em São Paulo", $14 / 05 / 2016$

Revista Consultório Jurídico, seção de opinião: "Cidadão tem o direito de obter imagens de câmeras públicas de segurança”; 26/10/2015

Revista Veja: "Empresas de segurança privada monitoram black blocs", 24/03/2014

Revista Veja São Paulo: "Polícia tenta identificar manifestantes que destruíram viatura", $01 / 09 / 2016$

Revista Vice: "Reconhecimento facial e redes sociais monitoradas: as armas da ABIN contra a ameaça do Estado Islâmico ao Brasil?", 15/04/2016

Revista Vice: "Manifestantes se dizem perseguidos pela polícia de SP", 18/10/2016

Secretaria Especial de Comunicação da Prefeitura de São Paulo: "Prefeitura de São Paulo lança site do programa City Câmeras", 11/07/2017.

SSP: "Mapa de Crimes", 17/04/2014

SSP: "Sistema de prevenção e investigação", 05/10/2015.

The New York Times: "Adviser to Emirates With Ties to Trump Aides Is Cooperating With Special Counsel", 06/03/2018

UOL Notícias: "Número de radares danificados por vândalos quase quadruplica em São Paulo", 18/02/2016

UOL Notícias: "Após implementação de principal bandeira de Alckmin para segurança, média de roubos sobe", 12/12/2017.

\section{Documentos:}

CIA-RDP80R01731R003200050006-0 Memorandum for Psychological Strategy Board. Subject: The U.S. Doctrinal Program, PDB D-33/2, May 5, 1953. pg. $1-2$.

CIA-RDP80R01731R003200050006-0 Memorandum for Psychological Strategy Board. Subject: The U.S. Doctrinal Program, PDB D-33/2, May 5, 1953. Pg. 6

SSP: "CARTILHA DE ADESÃO AO SISTEMA DETECTA - V3.0", Maio 2017

\section{Sítios de Internet}

https://apublica.org/2014/06/eua-treinaram-policiais-para-conter-manifestacoes-na-copal 
última atualização: 02/04/2018.

https://apublica.org/2017/04/meu-nome-nao-e-sininho/ última atualização: 02/04/2018.

http://fenapef.org.br/22587/ última atualização: 02/04/2018.

http://g1.globo.com/sao-paulo/noticia/2014/09/nao-houve-exagero-da-pm-diz-secretariosobre-reintegracao-em-sp.html última atualização: 02/04/2018.

https://g1.globo.com/sao-paulo/noticia/doria-sanciona-lei-que-penaliza-pichadores-commulta.ghtml última atualização: 02/04/2018.

https://jornalggn.com.br/noticia/secundaristas-sao-perseguidos-e-espancados-por-pmsem-sp. última atualização: 02/04/2018.

https://news.microsoft.com/pt-br/parceria-entre-governo-de-sp-e-microsoft-amplia-acoesde-inteligencia-policial/. última atualização: 02/04/2018.

https://noticias.uol.com.br/cotidiano/ultimas-noticias/2017/11/25/absolvicao-de-pms-quemataram-pichadores-e-desumana-e-segunda-violencia-do-estado-diz-viuva.htm. última atualização: 02/04/2018.

http://ndonline.com.br/florianopolis/coluna/helio-costa/vandalos-destroem-30-cameras-devigilancia-em-santa-catarina, última visualização 17/08/2016

https://oglobo.globo.com/brasil/alckmin-diz-que-vandalos-foram-responsaveis-por-acaono-metro-11508299 última atualização: 02/04/2018.

http://passapalavra.info/2014/07/97262 última atualização: 02/04/2018.

http://revistavirus.com.br/a-repressao-as-batalhas-de-rap-o-caso-do-abc-paulista/ última atualização: 02/04/2018.

http://sao-paulo.estadao.com.br/noticias/geral,adolescente-morre-apos-espancamentopraticado-por-policiais,70001747418; última atualização: 02/04/2018.

http://sao-paulo.estadao.com.br/noticias/geral,pista-de-skate-da-praca-roosevelt-epichada-24h-depois-de-inauguracao,1601802. última atualização: 02/04/2018.

http://sao-paulo.estadao.com.br/noticias/geral,sistema-de-video-contra-crime-ainda-efalho-diz-tce, 70001757034 última atualização: 02/04/2018.

http://videos.bol.uol.com.br/video/vandalos-usam-caminhao-de-lixo-para-quebrar-camerade-seguranca-em-sp-04024C193460C8915326 última atualização: 02/04/2018.

https://www.acheiusa.com/Noticia/policiais-brasileiros-fazem-intercambio-nos-estadosunidos-12579/ última atualização: 02/04/2018.

https://www.aljazeera.com/programmes/faultlines/2018/04/trump-war-gangs180410044407676.html última atualização: 02/04/2018.

https://www.avg.com/en/signal/windows-10-privacy-everything-you-need-to-know-to-keepwindows-10-from-spying-on-you última atualização: 02/04/2018. 
http://www.capital.sp.gov.br/noticia/prefeitura-de-sao-paulo-lanca-site-do-programa-citycameras última atualização: 02/04/2018.

http://www1.folha.uol.com.br/fsp/mais/fs23089804.htm última atualização: 02/04/2018.

https://www.huffpostbrasil.com/2016/05/06/adolescentes-arrastados-e-jornalista-agredidoem-ocupacao-de-est_a_21695361/; última atualização: 02/04/2018.

http://www.policia.sp.gov.br/noticia/lefotos.aspx?id=7335 última atualização: 02/04/2018.

http://www.saap.org.br/seguranca/saap-assina-convenio-inedito-com-secretaria-deseguranca-e-cameras-de-alto-dos-pinheiros-terao-conexao-direta-com-as-policiaspaulistas/ última atualização: 02/04/2018.

http://www.saopaulo.sp.gov.br/spnoticias/detecta-monitora-o-estado-de-sao-paulo-com-3mil-cameras-de-video/ última atualização: 02/04/2018.

http://www.saopaulo.sp.gov.br/spnoticias/ultimas-noticias/sistema-detecta-ganha-97novas-cameras-de-monitoramento/ última atualização: 02/04/2018.

http://www.ssp.sp.gov.br/acoes/leAcoes.aspx?id=33833 última atualização: 02/04/2018.

https://www.vice.com/pt_br/article/xyqmdz/batalha-da-matrix-sao-bernardo-sao-paulorepressao-policial última atualização: 02/04/2018.

http://www.vice.com/pt_br/read/manifestantes-se-dizem-perseguidos-pela-policia-de-sp, última atualização: 18/10/2016.

https://www.washingtonpost.com/news/the-switch/wp/2017/03/07/why-the-cia-is-usingyour-tvs-smartphones-and-cars-for-spying/?utm term=.1f744b64ccdf. última atualização: 02/04/2018. 